
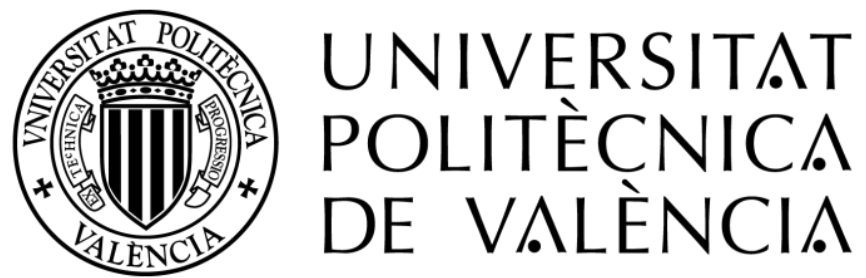

Facultad de Bellas Artes de San Carlos Departamento de Escultura

Programa de Doctorado:

ARTES VISUALES E INTERMEDIA

Tesis Doctoral

\title{
EL TEXTIL: \\ DEL MITO DEL ORIGEN A LA ERA MULTIMEDIA
}

Ma. Eugenia Yllades Nieto

Directora de Tesis

Dra. Dña. Maribel Doménech Ibáñez

Valencia, 2015 


\section{Índice}

Resumen en español $\quad 4$

Resumen en inglés $\quad 6$

Resumen en valenciano

Introducción

6

\section{Capítulo 1}

Tejido, texto y trama

1.1 Identidad, misticismo y ritual. 52

1.2 Creación, producto y sentido. 70

1.3 La Madre del Mundo 88

1.4 El mito del origen 112

- En el mundo náhuatl 117

- En el mundo maya 143

- Diosas y tejedoras 164

- Mujeres y tejido 182

\section{Capítulo 2}

Origen y creación.

El tejido como actividad primigenia 190

2.1 Dos cauces de lo originario 190

-Sentido mitológico 211

-Explicación científica 231 
2.2 El tejido como modelo en ambos cauces

\section{Capítulo 3}

El tejido cósmico en la ciencia contemporánea 253

3.1 Las tramas en la ciencia y en la historia 253

3.2 La teoría de las supercuerdas 280

3.3 La teoría de las membranas 292

\section{Capítulo 4}

Los mundos digitales $\quad 305$

4.1 Hacia una creación textil en la era multimedia 313

4.2 Una metáfora actual: tramas de hilos,

luz y sonidos en el arte.

Conclusión

Bibliografía

361 


\section{Resumen en español}

Esta tesis cuyo título es "El textil: del mito del origen a la era multimedia", aborda el tema del tejido y su pertenencia al ser humano como metáfora siempre presente a lo largo de su evolución en el planeta que habitamos. Se hace un acercamiento a ese desarrollo a través de las metáforas que siempre utilizamos como instrumento para explicar el mundo que nos rodea. El lenguaje tiene limitaciones para explicar algunos de los sectores del conocimiento humano, por lo que se han construido a lo largo de la historia, lenguajes apropiados a dichos campos: un ejemplo son las metáforas contenidas en los mitos que los seres humanos antiguos construyeron para explicar el origen del universo y la actividad de las personas, y otro podría ser el del lenguaje matemático que la ciencia utiliza para llegar al entendimiento de campos específicos del saber. Misticismo, ciencia y arte utilizan metáforas para comunicarse. Son tres campos que innegablemente conforman el pensamiento de la humanidad, aunque individualmente cada quien se incline por alguno o varios de esos campos.

A través del tiempo las metáforas perduran y siguen presentes en la explicación contemporánea del origen y la 
actividad del tejido se presenta como una posibilidad de relacionar. En este trabajo se analizan primero los mitos pertenecientes a las dos principales culturas mexicanas, pues ellas, como muchas otras concepciones arcaicas, representaron en su mitología la actividad de tejer como una de las actividades que fueron enseñadas a los humanos directamente por los dioses y que contenía el misterio de la creación. Luego se hace un breve recorrido por algunas de las culturas más importantes que utilizan la metáfora del tejido como forma de construcción del universo, para darnos cuenta de su importancia y finalmente se exploran las posibilidades que la tecnología y la ciencia han proporcionado en el campo de los hilos y las telas para construir la expresión contemporánea.

El papel de la mujer en estas metáforas es predominante, pues el elemento femenino como productor de vida, como creador, es primordial en la construcción de dichos mitos. La función de los textiles y el tejido en la cultura contemporánea mantienen su significado de unión, relación y construcción de algo nuevo por la unión de los elementos. El arte contemporáneo también ha incluido la metáfora y los materiales del tejido que manifiestan esa pertenencia del textil a la expresión del ser humano. 


\section{Resumen en inglés}

Summary

This thesis titled "The Textile: from the Myth of Origin to Multimedia Era", focuses on the issue of weaving as a distinctive activity of humans and as an always present metaphor throughout our evolution in this planet we inhabit. The thesis approaches this development by means of metaphors we always use as a tool to explain the world around us. Spoken language has limitations to explain some areas of human knowledge, and consequently, people have built new languages throughout history, languages more appropriate for these fields. An example of that are metaphors contained into myths elaborated by ancient cultures to explain the origin of the universe and behaviors of people. Another example could be the mathematical language used by science for understanding of specific fields of knowledge. Mysticism, science and art use metaphors to communicate. These three fields are basic along the conceptualization made by humankind in its history, though individually each one is inclined to one or more of these fields.

Over time, metaphors endure and are still present in contemporary explanation of origin, and the act of weaving emerges as a possibility in that connection. In these pages, we first discuss myths belonging to the two main 
ancient Mexican cultures, because these two, like many other archaic conceptions of cosmos, figured into their mythologies the activity of weaving as one gods taught directly to humans; and that teaching contained the mystery of creation. From that point, we made a brief review over some of most important cultures that use metaphor of weaving as a representation of the original frame of universe, in order to realize how important it is. At last, we explore the possibilities opened by technology and science in the field of threads and fabrics to build contemporary expressions. 


\section{Resumen en valenciano}

Aquesta tesi té com a títol: "El tèxtil: del mite de l'origen a l'era multimèdia", aborda el tema del teixit i la seva pertinença a l'ésser humà com a metàfora sempre present al llarg de la seva evolució al planeta que habitem. Es fa un apropament a aquest desenvolupament a través de les metàfores que sempre utilitzem com a instrument per explicar el món que ens envolta. El llenguatge té limitacions per a explicar alguns dels sectors del coneixement humà, de manera que s'han construït al llarg de la història, llenguatges apropiats a aquests camps: un exemple són les metàfores contingudes en els mites que els éssers humans antics van construir per explicar l'origen de l'univers i l'activitat de les persones, i un altre podria ser el del llenguatge matemàtic que la ciència utilitza per arribar a l'enteniment de camps específics del saber. Misticisme, ciència i art, fan servir metàfores per comunicar-se. Són tres camps que innegablement conformen el pensament de la humanitat, encara que individualment cadascú s'incline per algun o diversos d'aquests camps.

A través del temps, les metàfores perduren i segueixen presents en l'explicació contemporània de l'origen, i l'activitat del teixit es presenta com una possibilitat de 
relacionar. En aquest treball, s'analitzen primer els mites pertanyents a les dues principals cultures mexicanes, doncs elles, com moltes altres concepcions arcaiques, van representar en la seva mitologia l'activitat de teixir com una de les activitats que van ser ensenyades als humans directament pels déus i que contenia el misteri de la creació. Després es fa un breu recorregut per algunes de les cultures més importants que utilitzen la metàfora del teixit com a forma de construcció de l'univers, per adonar-nos de la seva importància i finalment s'exploren les possibilitats de la tecnologia i la ciència han proporcionat en el camp dels fils i les teles per construir l'expressió contemporània.

El paper de la dona en aquestes metàfores és predominant, ja que l'element femení com productor de vida, com a creador, és primordial en la construcció d'aquests mites. La funció dels tèxtils $\mathrm{i}$ el teixit en la cultura contemporània mantenen el seu significat d'unió, relació i construcció d'una cosa nova per la unió dels elements. L'Art contemporani també ha inclòs la metàfora i els materials del teixit que manifesten aquesta pertinença del tèxtil a l'expressió de l'ésser humà. 


\section{INTRODUCCIÓN}

I

Desde que somos humanos, una pregunta nos ha inquietado, como individuos y como culturas. ¿De dónde venimos? ¿Por qué existe todo lo que existe? $\mathrm{Y}$ seguimos intentando resolver la pregunta sobre el origen. Desde nuestro punto de vista, podemos decir que hay dos maneras de responder esa pregunta: la manera religiosa y la manera científica. Ambas dan sentido a las inquietudes que surgen en el interior del alma humana. Una por medio de los mitos y la otra por medio de modelos cosmológicos. Ambas son expresiones de una reflexión del ser humano sobre el universo que lo rodea. No se trata aquí de enfrentar ambas maneras de explicar el mundo, sino de comprender que cada una corresponde a distintas necesidades y que las dos son realidades que existen en este momento. También se trata de ver que la inquietud por responder aquella pregunta sobre el origen es más primitiva que el camino que se escoja, ya sea a través del misticismo o de la ciencia. Es interesante darnos cuenta que todas las culturas se han hecho esa pregunta y cada una construye sus metáforas para hacer comprensible la explicación del origen del mundo.

La ciencia contemporánea también utiliza metáforas, pues es la manera de avanzar en la comprensión de los 
fenómenos a los que no podemos acceder más que de una manera teórica muy compleja. El lenguaje metafórico permite el acceso, y utiliza símbolos que son relevantes para la cultura en que se construye dicha metáfora. Es decir, que utiliza imágenes que nos son familiares para explicar algo que rebasa esa familiaridad, algo que va más allá de lo que se puede entender directamente. Las metáforas son algo vivo, algo que cada cultura cultiva y entiende, es un mecanismo que utiliza la comparación y la relación con otros términos para facilitar el acercamiento a ciertos temas que de otro modo nos resultarían complejos. Existen todo tipo de metáforas, dependiendo del campo del que se trate. Pero la metáfora del tejido se puede rastrear en los campos más diversos. Por poner algunos ejemplos de la utilización que hacemos de las metáforas, se presentan las siguientes expresiones: "ya perdió el hilo de las cosas", "hilvana mal sus ideas", "el tejido social es...", "el desenlace de esa historia", "ahora estoy atando cabos", "está urdiendo su venganza", "algo estás tramando", y muchas, muchas más que utilizamos diariamente en la cotidianeidad y también en los discursos de distintas disciplinas. Las metáforas conllevan en sí mucho conocimiento, pero también un alto grado de imaginación. Siguiendo con la metáfora del tejido, ella nos permite entrar a un dominio de conocimiento común en 
nuestra cultura, pero también a un ámbito oculto, mágico, aunque al mismo tiempo cercano.

\begin{abstract}
"Por supuesto, los conceptos no emergen directamente sólo de la experiencia sino que están estructurados a partir de las metáforas culturales dominantes, y por supuesto una metáfora estructural como la de UN DISCURSO ES UN TEJIDO se construye dentro del sistema cultural en que se vive. Cuando se tejía en las casas o en regiones donde hay una gran cultura textil -como en mi caso es Cataluña- la trama, urdimbre, lanzadera, etc. son realidades físicas tan bien conocidas como el punto de cruz o el ganchillo. ${ }^{1}$
\end{abstract}

La metáfora funciona cuando trae esa carga cultural que nos es común a los que vivimos dentro de una determinada sociedad. Es por esta razón que también los mitos de las antiguas culturas se deben abordar intentando comprender las motivaciones y la significación que tenía para ellos en su momento, en su tiempo y en su ubicación y no únicamente con la carga que traemos perteneciente a nuestra propia cultura actual. Es necesario saber hacer esa separación entre las visiones pre-científica y científica. El conocimiento adquirido por

\footnotetext{
1 Jaime Nubiola: "El valor cognitivo de las metáforas" http://pages.uoregon.edu/tpayne/Nubiola.pdf.

Consultado el 10 de enero de 2013.
} 
los antiguos humanos, quienes no tenían todavía acceso a los instrumentos que permitieron el desarrollo de la ciencia, se adquiría de maneras muy distintas a las que nos ha presentado la cultura occidental; para poder abordar ese campo, es necesario contar con una mente abierta, que nos permita ubicarnos en el papel de aquellos seres humanos que nos precedieron y que pudieron encontrar respuestas verdaderas a sus inquietudes por el origen y el funcionamiento del universo.

Está en nuestra naturaleza esa irresistible atracción por lo desconocido, ese reto que representa explicar lo que está fuera de nuestra realidad cotidiana, lo que sobrepasa los límites de nuestro campo de acción directa.

Mucho antes de que el conocimiento científico existiera, observábamos la naturaleza y le temíamos. No había manera de defenderse de los sucesos del medio ambiente. De tal manera, el ser humano consideraba que fuerzas superiores regían su destino, pues no había manera de acercarse y comprender, más bien había que alejarse para protegerse. Poco a poco cada cultura construyó su gama de dioses a los que atribuía una fuerza de la naturaleza, dependiendo de los elementos que más afectaran a su comunidad por el lugar geográfico donde se ubicaban. Es justo decir que la observación de la naturaleza les permitió construir un orden y avanzar en el conocimiento de los que los rodeaba. Las culturas más 
sofisticadas llegaron a conocer muy bien los movimientos de los astros en el cielo y las estaciones y una parte de los eventos naturales que tendrían lugar en un periodo determinado de tiempo.

Ese conocimiento se combinaba con modelos míticos y elementos mágicos que los humanos más inquisitivos de esas comunidades construían para explicar de una manera accesible los sucesos naturales a los demás.

El conjunto de creencias y mitos, servía para dar cohesión a un grupo social, para garantizar el bienestar del grupo, pero también para satisfacer sus necesidades espirituales y alejar el temor. En las culturas mesoamericanas, existía el temor a que el universo no funcionara de manera adecuada y se llevaban a cabo ceremonias y sacrificios para garantizar la existencia continuada del mundo. Otra cosa que ha existido siempre es el temor a la muerte y había que tranquilizar el espíritu dándole una explicación mística a dicho suceso impredecible. Para las personas de todas las épocas ha sido importante entender de dónde venimos porque de esa manera podemos explicarnos a dónde vamos cuando la muerte llegue.

Por su parte, la ciencia contemporánea también busca ese entender las causas últimas de la existencia, e intenta dar respuestas universales que no dependan de la cultura o la religión. Los científicos son los creadores de "mitos" contemporáneos, en el sentido de que se construye un 
lenguaje específico para explicar a los neófitos, e intentan desenvolver el enigma para acercarse a él de una manera que dé soluciones de manera universal, válidas para todos porque son demostrables gracias a la tecnología.

No podemos salirnos del universo para explicarlo porque somos parte de él. Y las medidas que hacemos de sus fenómenos las debemos hacer ateniéndonos a la realidad en la que nos movemos. En este mundo percibimos que existen opuestos y que en base a ellos tomamos decisiones y construimos varios tipos de orden para hacer manejable nuestra realidad. Pero hay cosas que no obedecen a dichos opuestos y son las más difíciles de explicar. Aún así, necesitamos que nuestro punto de vista tenga un orden y un significado.

Los mitos de la creación son los que más dicen acerca de una cultura debido a su profunda naturaleza y esto incluye también al tema del origen en la cosmología actual. Ambos sectores contienen la evidencia de que el pensamiento humano tiene aspectos y preguntas universales, que son los mismos en los humanos antiguos $y$ en los de ahora, en las personas religiosas y en las ateas, independientemente de la región que se habite, etc.

Marcelo Gleiser propone una clasificación de los mitos cosmogónicos en las diversas culturas que han existido. Es una generalización que me parece, da un orden a los 
tipos de manifestación mítica acerca del origen. Su cuadro quedaría como sigue:²

\section{A CLASSIFICATION \\ OF \\ COSMOGONICAL MYTHS}

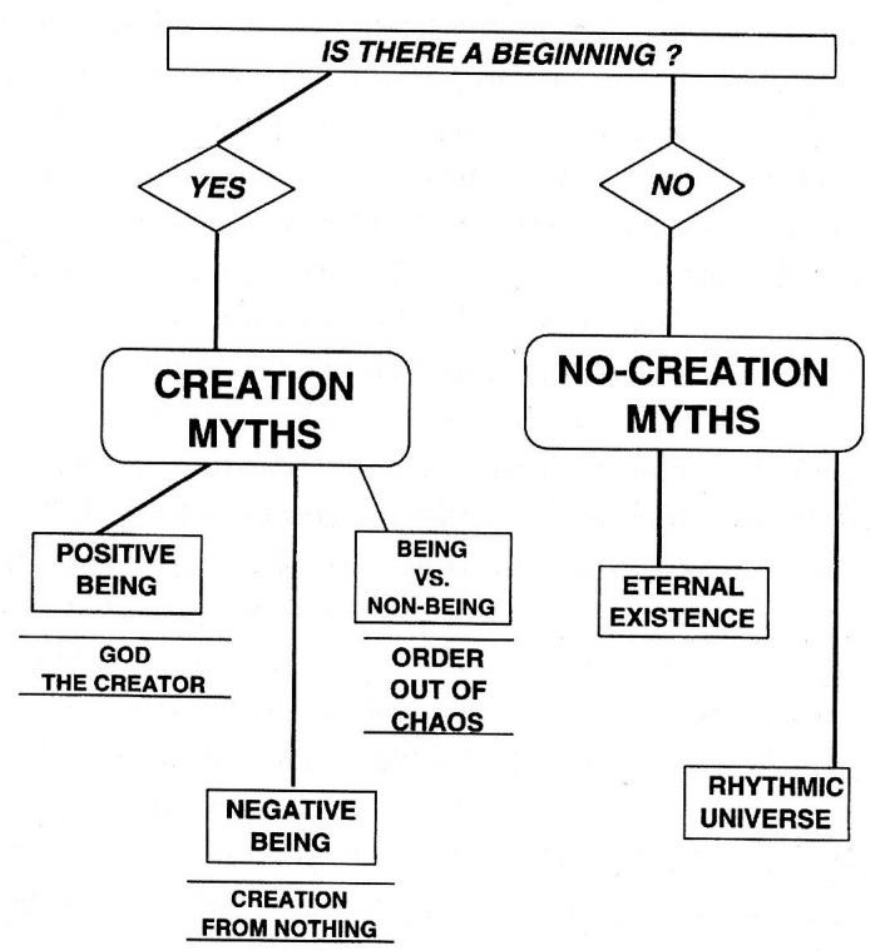

Different mythological responses to "the Question," the origin of the Universe

A la pregunta de si hay un inicio de todo, se ha respondido con dos posibles respuestas: una positiva, de

${ }^{2}$ Gleiser, Marcelo. The Dancing Universe, p. 12. 
donde surgen los mitos creacionistas y de ahí se dividen en mitos donde hay un ser positivo, que sería dios domo el creador de todo; mitos donde se niega el ser primordial y se concibe la creación desde la nada; y mitos donde el ser es dual y existe una lucha entre el ser y el no-ser, de este caos surge el orden por medio de la continua lucha de los opuestos. La otra posible respuesta es de orden negativo y de ahí se derivan los mitos no creacionistas, que postulan una existencia eterna de todo en donde nada se aniquila para siempre, y otros mitos donde el universo posee un ritmo eterno y constante y los ciclos se suceden interminablemente.

Esta clasificación propuesta por Gleiser nos ayuda para ver de manera esquemática las respuestas que las diferentes culturas han encontrado para explicar la creación, el inicio de todo, responder al por qué las cosas funcionan como funcionan y de qué manera todo va evolucionando hasta llegar al momento en que se plantea la pregunta, no importa si fue en el principio de los tiempos históricos o en la actualidad.

El tiempo es un factor importante en la concepción de estos mitos, en algunos transcurre linealmente sin principio ni fin, con una existencia eterna; en otros comenzó en un punto determinado y a partir de ahí empezó todo el universo sin que se sepa cuándo se 
detendrá; en otros forma una espiral o un círculo en el cual todo se repite, de manera rítmica y regular.

Como se verá más adelante el tiempo es una de las constantes en el pensamiento del ser humano y juega un papel primordial en las concepciones acerca del origen. Las combinaciones que se hacen entre el tiempo y el espacio cambian en cada cultura, en cada grupo, en cada época; el acomodo de esas dimensiones que percibimos y en las cuales nos movemos cotidianamente determina nuestra explicación del universo.

En las culturas antiguas, el mito surge ante la necesidad de tener una explicación, de dar un orden al caos. La observación del cielo sobre todo, hizo que se pudieran obtener las constantes necesarias sobre las cuales se construyó la estructura que permite dicho orden. Las constelaciones, el movimiento de los astros cada noche, permiten relacionar los sucesos del mundo; así, los antiguos construyeron su historia primordial, percibida por los observadores del cielo y dándole sentido a las normas que podían regir la vida de la sociedad en la que habitaban. ${ }^{3}$

Los elementos se clasificaron y se concibieron dioses que los personificaban. Se descubrieron los ciclos de las estaciones cuya medida también tenía que ver con el movimiento de los astros. El cielo, esa constante, permitió

${ }^{3}$ Eliade, Mircea. Mito y realidad. Ed. Labor. 1991, p. 11. 
arreglar el mundo inmediato y entender los sucesos que afectaban a los seres humanos.

Los principios naturales ahora tenían sentido, los humanos podía dirigirse a los dioses que los regían para mitigar sus efectos negativos y potenciar los que podían beneficiarlo.

A partir de ahí, el desarrollo gradual del pensamiento del ser humano y el cambio de sus sociedades, ha permitido trazar líneas alternativas a lo religioso y que han conducido al establecimiento de las leyes de la física contemporánea. Aunque la pregunta sobre la creación no haya podido ser plenamente respondida, pequeños trozos de la realidad que han develado sus misterios nos permiten, sin embargo, obtener algunas posibles respuestas y seguimos queriendo construir esa teoría que ordene todas las fuerzas de lo que hemos podido atisbar en las dimensiones diminutas de las partículas que forman la materia y la energía y en las inmensas fuerzas que funcionan en el espacio.

Pero la aspiración de nuestros días sigue siendo la misma que la de aquellos antiguos antepasados, entender de dónde venimos y a dónde vamos, y sobre todo, ver cuál es nuestro papel en la interacción de dichas fuerzas que aún son un gran misterio para la humanidad.

Se considera a los griegos como los primeros que abrieron el primer cauce para el pensamiento racional y 
que buscaban una explicación al margen de los cauces religiosos, observando los fenómenos naturales por sí mismos. Desde Tales y Anaximandro que comenzaron la búsqueda de explicaciones en la naturaleza misma, hasta Demócrito que pudo concebir el átomo (como lo que no puede ser dividido), los griegos presocráticos quisieron encontrar la presencia del ser como tal por medio de cálculos matemáticos.

Aunque debemos entender que en los primeros tiempos de la cultura a la que pertenecían, todo se concebía de forma integral; tanto la religión como la filosofía y la ciencia formaban parte de un mismo acceso al conocimiento. Luego será con los filósofos de la escuela de Elea que empezarán a separarse dichos tipos de conocimiento. Su importancia histórica radica en que sentaron las bases para el pensamiento que intentaba utilizar la imaginación y el conocimiento para algo que no fuera mágico.

Después de ellos, los filósofos continuaron avanzando en dar con la explicación del movimiento del universo y tanto Platón, con su concepción matemática abstracta, como Aristóteles con su división más práctica y empírica de las ciencias, sostuvieron su influencia durante los siguientes siglos, de hecho hasta hace relativamente poco. Aunque el avance del pensamiento no deja nunca de tener una función social, contiene además la búsqueda de una 
libertad, liberarse del temor buscando además liberarse de la subjetividad, sin que eso signifique menospreciar al individuo; al contrario, son necesarias muchas voluntades, razones, e imaginaciones para hacer cualquier avance en la ciencia.

Aunque ahora, - vistos con nuestros ojos desde la ciencia construida por la civilización occidental一, nos parezcan un poco extraños o ajenos a nosotros, tanto los modelos de los mitos antiguos como los de los griegos o las de otras civilizaciones, han proporcionado datos que conducen a la evolución del pensamiento humano.

II

En este trabajo se abordará un tema que no ha sido objeto común de reflexión estética hasta hace muy poco: el tejido. Es posible que esto haya sucedido por el estatus tradicional al que la costumbre de la sociedad occidental ha relegado a esa actividad.

Existe un prejuicio contra la actividad de tejer o coser por considerarse labor femenina, manual y doméstica, y todavía hay mucha presión sobre las mujeres que intentan expresarse dentro del campo del arte con estos medios. Pero es ahora cuando más necesaria se hace la reflexión sobre las nuevas manifestaciones artísticas y su universo de posibilidades. 
La tecnología ha permitido que el arte se difunda como nunca antes, por ser el instrumento de conocimiento más inmediato en nuestra sociedad, y además por poner a disposición de los artistas los mecanismos que permiten explorar realidades e interpretaciones insospechadas.

La correlación de temas de disciplinas tan diversas, como pueden ser en el caso del trabajo que nos ocupa, los mitos, el arte textil y de la fibra, las teorías contemporáneas que explican el origen del universo y los dispositivos digitales que incorporan nuevos sentidos y sensaciones al arte, son parte de un muy variado patrón que ya muchos abordan en su acercamiento a la sensibilidad y posibilidades de expresión integral humana. La metáfora del tejido puede funcionar tanto en los mitos arcaicos como en la explicación científica contemporánea del mundo. El cruzar elementos sencillos como son los hilos o las cuerdas, da lugar a otra realidad, más compleja y completa: el de las fuerzas que al unirse andan diversos caminos y construyen algo nuevo. A partir del principio creador, ese "tejer" constituye el ordenamiento de la energía disponible en sencillos hilos para acceder a las infinitas combinaciones de la creatividad y de las formas de vida.

La motivación personal para elaborar este trabajo proviene de mi interés por el tejido y me gustaría decir que éste comenzó fortuitamente, pero las diversas etapas 
por las que pasé despertaron una necesidad de reflexión acerca de esa actividad y me llevaron a emprender un recorrido por las diversas áreas que comprende. Desde las primeras fibras entrecruzadas, hasta los más nuevos modos de expresión que han logrado los hilos y las fibras en el arte contemporáneo, pasando por el tejido de producción artesanal y el de producción en masa, el proceso humano de tejer ha llamado mi atención poderosamente.

El hecho de poder crear yo misma una tela por el simple pasar de hilos, me parecía algo muy satisfactorio, el repetir un paisaje, o un motivo cualquiera, me convencía de que era posible obtener la imagen en un medio diferente a la estampa, pintura o fotografía. Luego comencé a aprender técnicas más elaboradas que permitían distintos efectos en el plano. $Y$ al buscar quién surtiera la materia prima con la que inicialmente trabajaba, la lana, fui conociendo a los artesanos que hacían del tejido un modo de vida y su oficio más querido. Entre ellos, el tejer completaba bien su estilo de vida, pues mientras las lluvias hacían su trabajo haciendo crecer las milpas en la tierra sembrada, ellos podían dedicar su tiempo y sus manos a tejer en el telar y a hacer crecer la tela con sus hilos.

Esta cercanía con los genuinos tejedores de sarapes, rebozos y jorongos, prendas que alguna vez fueron de 
uso básico en México, me dio una perspectiva distinta al comprender cómo desarrollaban ellos su oficio, y me permitió diferenciar el trabajo al que llaman artesanal y notar que el mío iba en otra dirección. Entonces comprendí que no podía competir con aquellos maestros en su ramo, de hecho no buscaba eso, y al ir avanzando y experimentando con materiales, técnicas y modos de tejer, fui descubriendo que los distintos materiales con los que trabajaba tenían infinitas posibilidades. La tecnología vino en mi ayuda y pude ver lo que se estaba haciendo alrededor del mundo en esta área y sentí que ese era mi lugar. Por fin había encontrado el sendero para mi quehacer con los hilos. Pero no paró ahí.

Comencé a preguntarme por el origen del tejido, por cuántas maneras de tejer había y mi oficio de historiadora trajo más preguntas: cómo se desarrolló el tejido en las diferentes civilizaciones y sobre todo en las culturas de las que provengo, cuál era el modo en que el tejido ha transcurrido y transcurre, desde la artesanía, pasando por la manualidad y la producción fabril, hasta el arte contemporáneo en sus diferentes manifestaciones.

Recorrí territorios del estado enseñando a tejer en comunidades apartadas de las ciudades, indagué con los últimos sobrevivientes del oficio en mi región, e investigué entre los artistas de la fibra. Todo parecía pertenecer a un contenido primitivo en el ser humano. $Y$ entonces acudí a 
los expertos para saber qué significaba el tejido y sus conceptos en las sociedades primitivas.

Mi gusto creció cuando empecé a descubrir el significado del tejer y sus instrumentos y símbolos en las sociedades arcaicas. La relación con la divinidad y la conformación del mundo, la posibilidad de formar parte del ánima creadora al dar vida a la tela y a los símbolos que en ella descansan, las metáforas que se usaban para explicar el modo que tenían los dioses para realizar el universo y el modo en el que estaba, —digámoslo propiamente-, entretejido el mundo, surgían como temas fascinantes.

La magia que ocurría en el mundo cuando los dioses combinaban las fuerzas naturales, parecía repetirse, igual que en aquellas sociedades antiguas en la labor creativa del tejer, en el arte contemporáneo. Símbolos, significados, alegorías, metáforas, todo me parecía existir desde siempre y en todos los planos de la historia humana.

El placer de las lecturas hechas en este periodo, a partir del estudio de los expertos en los mitos de las sociedades arcaicas, aumentó cuando abordaba las culturas prehispánicas, tan cercanas a mi mundo. $Y$ aún más interesante fue cuando comprobé el papel femenino en dichos mitos y actividades creadoras relacionadas con el tejer. La cuestión de género, tan presente en estos días en los que vivimos, surgió por sí misma y con toda la 
fuerza que tienen siempre los papeles vividos genuinamente por las mujeres.

No podía ser mejor, pero de repente, un reportaje sobre el origen del universo llamó poderosamente mi atención tan sólo por el título: La teoría de las cuerdas. Indagué un poco más y descubrí, no sin asombro, que la más moderna teoría para explicar el origen y la conformación del universo tenía que ver con los conceptos que había estado viendo en las sociedades antiguas.

Todo el conjunto formaba un intrincado laberinto de elementos comunes. $Y$ me dispuse, no sin alguna reserva por cuanto abarcaba y los elementos en apariencia tan dispares que pretendía reunir, a investigar sobre el asunto y a recorrer el laberinto. Admito que me encontraba en una situación que despertaba emociones contradictorias dentro de mi ánimo. Por un lado, las lecturas me apasionaban y a veces me perdía en el disfrute de los textos olvidando el registro necesario para la investigación; otras veces no quería leer porque me disgustaba tener que hacer dicho registro. Me perdía en la vastedad del tema y en el gran número de relaciones que se podían construir con los términos que iban surgiendo. El lenguaje, la sociedad, las relaciones humanas, todo cabía en el entramado, pero tenía que limitarme al tema escogido, así que me dispuse a delimitar el tema y a 
comenzar a escribir planteando la hipótesis, los objetivos y la metodología a seguir.

La hipótesis planteada en esta investigación intenta mostrar cómo la metáfora del tejido ha sido construida y sigue junto al ser humano desde los primeros tiempos, por lo que se encuentra presente en la explicación del origen del mundo, tanto en la antigüedad como en la actualidad. También se busca mostrar cómo el tejido es tan ubicuo que se puede encontrar desde los mitos arcaicos, pasando por la ciencia en la física contemporánea, hasta las más nuevas manifestaciones del arte actual.

El objetivo general de esta tesis es indagar sobre la vinculación de los términos texto, tejido y trama, y hacer notar cómo a través de las metáforas del textil se explica el mundo que nos rodea. Para esto se analizan las metáforas contenidas en los mitos que explican su origen y se plantea cómo el Misticismo, la Ciencia y el Arte utilizan metáforas para comunicarse actualizando su lenguaje hasta nuestros días.

Hemos planteado en este estudio los siguientes objetivos específicos:

1.-Estudiar el origen del textil y la existencia de todo lo creado, así como su lógica en las civilizaciones antiguas. 
2.-Conocer la cosmogonía de las culturas que tienen el tejido y la trama como eje articulador de su cultura.

3.-Analizar la posibilidad del arte textil como testigo de la vida en el arte contemporáneo.

4.-Hacer un breve recorrido histórico, basado en las referencias teóricas y prácticas sobre el uso del textil en el arte.

5.-Reflexionar sobre la presencia y la voz de la mujer observando su incorporación a las expresiones del tejido, las telas y los hilos.

6.-Revisar y profundizar en el uso que hace la ciencia de los elementos del tejido y sobre las nuevas tecnologías del textil multimedia como medio de conocimiento y su aplicación en el arte actual.

7.-Analizar el uso de un lenguaje metafórico y simbólico para utilizar en los mitos de las distintas culturas que tienen relación con el tejer el mundo y ver cómo se construye dicho lenguaje.

Metodologías utilizadas en este trabajo:

Metodología deductiva: el método deductivo es aquel que parte de datos generales aceptados como válidos para llegar a una conclusión de tipo particular. El verbo deducir hace referencia a la extracción de consecuencias a partir de una proposición. 
Metodología cualitativa: en la investigación cualitativa se hace referencia a un grupo de métodos de investigación de base lingüístico-semiótica utilizados principalmente en las ciencias sociales. Se suelen considerar técnicas cualitativas todas aquellas distintas a la encuesta y al experimento. Es decir, entrevistas abiertas, grupos de discusión o técnicas de observación y observación participante. En este tipo de metodología se pretende una comprensión holística. El postulado característico de dicho paradigma es que lo "subjetivo" no sólo puede ser fuente de conocimiento, sino presupuesto metodológico y objeto de la ciencia misma.

Metodología Etnográfica: es aquella que, aplicada a la investigación, estudia las cualidades y características del objeto de estudio mediante la observación participante. Puede usarse como sinónimo de antropología, pero también para hablar de la observación participante como método de trabajo. Se traduce etimológicamente como estudio de las etnias y significa el análisis del modo de vida de una raza o grupo de individuos, mediante la observación y descripción de lo que la gente hace, cómo se comportan y cómo interactúan entre sí, para describir sus creencias, valores, motivaciones, perspectivas y cómo éstos pueden variar en diferentes momentos $y$ circunstancias. Podríamos decir que describe las múltiples formas de vida de los seres humanos. Tendría tres 
paradigmas: el holístico (estudia la cultura como un todo integrado); Conducta (estudia las variaciones de la conducta cultural) y Semiótico o interpretativo (entiende la conducta como cogniciones compartidas).

Metodologías exploratoria, descriptiva y explicativa. Exploratoria: son las investigaciones que pretenden darnos una visión general de tipo aproximativo respecto a una determinada realidad. Este tipo de investigación se realiza especialmente cuando el tema escogido ha sido poco explorado y reconocido y cuando aún es difícil formular hipótesis precisas o de cierta generalidad sobre dicho tema. Suelen surgir también cuando aparece un nuevo fenómeno, que precisamente por su novedad, no admite todavía una descripción sistemática, o cuando los recursos de que dispone el investigador resultan insuficientes como para emprender un trabajo más profundo.

Metodologías descriptivas: su preocupación primordial radica en describir algunas características fundamentales de conjuntos homogéneos de fenómenos, utilizando criterios sistemáticos que permitan poner de manifiesto su estructura o comportamiento. De esta forma se pueden obtener las notas que caracterizan a la realidad estudiada. Su meta no se limita a la recolección de datos sino a la predicción o identificación que existe entre las variables. 
Metodologías explicativas: son aquellos métodos que se centran en determinar los orígenes o las causas de un determinado conjunto de fenómenos, donde el objetivo es conocer por qué suceden ciertos hechos a través de la delimitación de las relaciones causales existentes, o al menos, en las condiciones en que ellas se producen. Este es el tipo de investigación que más profundiza nuestro conocimiento de la realidad, porque nos explica la razón, el porqué de las cosas, y es por lo tanto más complejo y delicado, pues el riesgo de cometer errores aumenta considerablemente.

\section{III}

El tejido ha acompañado al ser humano desde sus primeras andanzas por el mundo. Las cuerdas que ofrece el mundo natural pronto fueron instrumentos que los primitivos utilizaron para su beneficio. ¿Cuándo empezó a tejer el ser humano? es una pregunta que no puede ser contestada con precisión, pero sí podemos afirmar que las redes para cazar y pescar fueron las primeras manifestaciones del entrelazar cuerdas. El acto de entrelazar se convirtió en un acto mágico por la transformación que llevaba a cabo. Una simple cuerda se convertía, con el acto de tejer, en una fuerte membrana que atrapa, cubre, sujeta, pero a la vez deja salir sustancias más sutiles como el agua y el aire. Ese 
aprendizaje que hoy nos puede parecer simple, tiene todavía un significado profundo para la psique del humano.

Es probable que actualmente no nos sorprenda el hecho de que el tejido haya formado parte tan importante en las culturas antiguas, pero tal vez sin darnos cuenta cabal, lo tenemos tan arraigado que seguimos utilizando las metáforas que incluyen redes, tejido y cuerdas para explicar hechos relevantes tales como la conformación del universo, o las utilizamos en el planteamiento de diversas teorías que explican el lenguaje, o la sociedad. Y así ha sido a lo largo de la historia, en casi todas las culturas.

Los mitos orientales y europeos más antiguos incluyen dichas metáforas en el planteamiento de situaciones que tienen que ver con la conexión entre el cielo y las personas, con actividades que fueron enseñadas por los dioses, con la construcción del destino humano. No hace falta más que echar una mirada a esos tiempos y nos encontramos con cosas tan sabidas como el hilo que tejen las Moiras griegas para determinar la vida de las personas, o las cuerdas hindúes que sostenidas en sí mismas permiten una comunicación con el plano celestial, por mencionar los más conocidos. $Y$ eso sin recorrer el mundo mágico de las culturas que consideramos primitivas y que aún sobreviven y en las que aún perduran mitos que están vigentes. 
Podemos acercarnos al acto de tejer señalando que involucra un encuentro de fuerzas, un interactuar de energías de distinta naturaleza que se combinan para conformar algo totalmente diferente a lo que en un principio eran. Yendo de la más conocida metáfora, tejer el destino, hasta las más complicadas como la teoría de las cuerdas o la teoría $M$ que plantean los modelos cuánticos contemporáneos, hemos encontrado analogías que podemos seguir fácilmente en los términos y metáforas que tienen que ver con el tejido: anudar, tramar, urdir, hilos, cuerdas, tejer, las cuales pueden aplicarse a muchas situaciones de la realidad humana, y todas tienen que ver con un interactuar, con un conectar realidades, con algo a través de lo cual podemos comunicarnos.

La significación que a través del tiempo le hemos dado a dichas metáforas tiene que ver, como mencionamos antes, con la necesidad de explicar situaciones en términos que nos hagan sentir cómodos, y el tejido y su contexto, por la cercanía que tiene con el ser humano desde tiempos lejanos; es uno de esos campos de los que podemos tomar los conceptos y el texto a través de los cuales podemos entender realidades más complejas, sobre todo las que tienen que ver con la conexión entre lo divino y lo humano. 
Se pueden encontrar muchos ritos y símbolos que tienen que ver con las cuerdas y el tejer en las culturas antiguas de todo el mundo; Mircea Eliade ${ }^{4}$ ha estudiado esos mitos en lugares tan distintos como, la India, Australia, China, Irlanda, México, etc. Para estas culturas, la cuerda era la comunicación que había en tiempos remotos con la morada de los dioses y permitía que ellos bajaran a la tierra y el ser humano a su vez subiera a los cielos escalando esa cuerda. Pero por alguna falta cometida por la gente, esa cuerda se cortó y se interrumpió la comunicación entre los dos planos, haciendo al humano mortal y dejando solamente a algunos cuantos iniciados o privilegiados el acceso a dicha cuerda. Estos mitos son bastante antiguos y las imágenes de cuerdas o hilos son ampliamente utilizadas en los relatos de cosmogonía en muchas culturas.

Los hilos tienen la función de unir, o enlazar, y es una analogía que permite al ser humano sentirse parte de la naturaleza y de lo mágico y lo divino. El tiempo juega un importante papel en la metáfora del tejido; así como tejer un lienzo se lleva tiempo y es una labor que requiere paciencia y meticulosidad, ese tiempo que transcurre mientras se da forma a los hilos es un tiempo que en las culturas antiguas se consideraba mágico, era un tiempo

\footnotetext{
${ }^{4}$ Mircea Eliade es un autor rumano que trata con seriedad los temas sobre el mito en distintas culturas. (Ver bibliografía)
} 
que no era terrestre, sino que se entraba en otro tiempo mítico y cósmico, era el llamado tiempo primordial.

La trama siempre tiene relación con el crear, ya sea el mundo entero o un sencillo símbolo en la tela y como dice Eliade, toda existencia en el tiempo implica una "articulación" o una "trama". Las tramas están tan arraigadas en el ser humano, que a pesar de todas las transformaciones históricas, artísticas y tecnológicas, se responde a una pulsión originaria, al entrelazar las diferentes hebras en todos los ámbitos de la psique y la cultura.

¿Cuántas veces volteamos al cielo por las noches? En estos tiempos en que la electricidad nos da todo lo que necesitamos, el cielo nocturno ha sido borrado de encima de nuestras cabezas. Especialmente si vivimos en las ciudades que han sido profusamente iluminadas. Con luz no se puede mirar las estrellas. Nuestra vida cotidiana no nos da un espacio para mirar constelaciones y estrellas fugaces. Pocas veces al mirar el cielo nocturno pensamos en que ahí fue donde comenzó todo, en que estamos contemplando el escenario del origen del cosmos, de la totalidad de lo que conocemos.

En cambio, las personas de las civilizaciones antiguas dedicaron gran cantidad de tiempo a observar el cielo. De ahí surgió la explicación del origen del mundo y la creación, tanto de esos mitos ancestrales como de la 
teoría contemporánea del origen. Los casos que trataremos aquí pertenecen a las dos culturas más importantes de México: la azteca y la civilización maya que habitaron en la zona que se conoce hoy como Mesoamérica ${ }^{5}$ y en la que, como se ha descubierto, se compartían los mismos fundamentos culturales básicos.

Sus conocimientos astronómicos y sus cálculos precisos son impresionantes si consideramos que no tuvieron grandes telescopios ni la tecnología de la que disponemos ahora. Ellos situaron la explicación del mundo en ese cielo que observaban por las noches. Construyeron su propio escenario primigenio en ese universo estelar y el cielo significó para ellos un mundo mágico y espiritual del que formaban parte y en el que cualquier acción realizada contribuía a su conservación y desarrollo.

La concepción del origen y la existencia de todo lo creado tienen su propia lógica en las civilizaciones antiguas. Estas culturas han sido objeto de múltiples estudios y siguen siendo un tema inacabado debido a su complejidad, sobre todo en el caso de la cultura maya,

\footnotetext{
${ }^{5}$ El término Mesoamérica se acuñó para denominar la zona que comprende desde Honduras hasta la mitad del México actual y aunque sus límites siguen siendo objeto de debate, debido a que las influencias de las culturas que se desarrollaron ahí llegan hasta los estados de Nuevo México y Arizona, es un término que ha sido muy usado y sigue siendo verdaderamente útil para los estudiosos de las culturas prehispánicas.
} 
que sigue viva en los grupos que habitan lo que ahora es el sur de México y Guatemala.

También las hemos escogido, porque junto con la civilización andina en Sudamérica, fueron las más importantes y forman parte de un conjunto que normalmente no es tomado en cuenta dentro de la historia universal eurocentrista; además, es conveniente saber que en un cuadro comparativo del desarrollo de las culturas antiguas, tuvieron un avance similar a las antiguas civilizaciones europeas en cuanto a los factores que determinan el avance de las civilizaciones. ${ }^{6}$

El conocimiento del cosmos antiguo al que podemos acceder gracias al estudio de dichas culturas, enriquece nuestra concepción del mundo y aumenta la comprensión de la psique humana al lidiar con la pregunta acerca del origen de todo lo existente, además, nos permite ver la belleza de dichas concepciones al considerar al ser humano como elemento activo en la perduración del universo, aunque no por eso dejamos a un lado la valoración de los descubrimientos científicos de nuestra época tecnologizada. Por el contrario, con la comparación de sus conocimientos antiguos y los conocimientos que existen en la actualidad, entramos a ese mundo donde lo

${ }^{6}$ León-Portilla, Miguel. Toltecáyotl. P. 48. (Ver el cuadro "Desarrollo de las altas culturas con orígenes autónomos"). 
mágico se combina con la exactitud de la observación que hicieron.

Y como se mencionó antes, es entonces que podemos darnos cuenta del papel que jugaba el humano en el cosmos, su importancia en el funcionamiento del universo, a diferencia de la marginalidad en la que estamos ahora el común de los mortales respecto de la investigación científica contemporánea. La humanidad contemporánea no tiene un papel que jugar en la creación y juega mal su papel de conservador del mundo. Sólo puede acercarse al origen del cosmos desde un lugar lejano, ajeno a cualquiera de sus manifestaciones. Para nuestra concepción actual, el universo existiría aún si no hubiera humanos, cosa que no era posible en las concepciones arcaicas.

Para tener un acercamiento a la comprensión de los grandes mitos de las culturas antiguas, debemos tener presente que estamos limitados por nuestros propios filtros culturales; todo lo que podemos percibir está influenciado por la manera en que concebimos el presente. Nuestras reconstrucciones siempre serán interpretaciones de algo que ya no nos pertenece. $Y$ de hecho, la explicación contemporánea del origen tampoco nos pertenece en el sentido de que no somos más que una minúscula parte, ausente y ajena para las fuerzas que siguen construyendo el universo que nos rodea. 
En el primer capítulo se tratará de ver cómo se teje el mundo antiguo a través de varios conceptos que son importantes para sentar las bases del tema, tales como identidad, misticismo, ritual, creación, producto y sentido, conceptos que aún nos definen en la sociedad contemporánea respecto a los temas que se tratan a lo largo de este texto.

Tanto en el mundo antiguo como en el actual, los seres humanos necesitamos sentirnos parte de un conglomerado que nos proporcione identidad; identidad como individuos y como parte de un grupo, ya sea a través de creencias relacionadas con lo místico, o con lo puramente científico.

El ser humano necesita, debido a la conformación de su psicología, realizar acciones que le den seguridad, véanse como ejemplo los rituales arcaicos o los rituales contemporáneos aún si no están relacionados con lo religioso, pues tendemos a repetir los actos que nos garanticen el éxito o que nos proporcionen una sensación de que lo hicimos bien y que por tanto es difícil el fallo. Los resultados de la acción son los productos que contienen la creación, así para los dioses como para los seres humanos. La acción creadora dota a los productos de un sentido que se dirige a la sensibilidad. El producto divino, el científico, el artístico, proporcionan una visión 
distinta del mundo de lo cotidiano y de lo que simplemente es captado por los ojos.

En este capítulo, además, se aborda la parte femenina ligada a la creación, al origen y al tejido, viendo el papel desempeñado por la mujer en la producción de mitos y productos culturales. Haremos un acercamiento a lo femenino desde la concepción dualista de los dioses en la antigüedad y de las características que le pertenecen en las culturas de que tratamos, además del papel que desempeñaban las mujeres en la vida práctica y simbólica. En esta condición dual el hombre y la mujer tienen la misma importancia y uno complementa al otro, además de que ella fungía como portadora de conocimiento como se puntualizará en el cuerpo del texto. Luego, iremos directamente a las dos culturas que se van a tratar, la cultura azteca y la maya para abordar los mitos de la creación, la concepción que ellos tenían sobre la totalidad, y el concepto de que todo es parte de lo mismo, de que nada está separado ni puede existir independientemente de todo lo demás. Describiremos los principales mitos de la creación en las dos culturas estudiadas reflexionando sobre los conceptos extendidos que se encuentran en sus metáforas. La coincidencia entre el mundo habitado por los dioses y su reflejo en la vida de la comunidad, resaltaba el papel activo del individuo en la conservación del orden cósmico, natural y 
social. Se verá cómo la concepción de la creación del mundo afecta la vida cotidiana en esas culturas de maneras que ya no existen en nuestras sociedades contemporáneas.

Veremos el papel de la mujer, las metáforas con el tejido, la actividad misma del tejido, las diosas que enseñaron a tejer y el sentido simbólico de sus varios atributos además de la importancia de ese oficio en las sociedades prehispánicas de Mesoamérica.

En el segundo capítulo, escudriñando en la creación y el origen se definirá lo originario desde el punto de vista mitológico y desde el punto de vista científico para tener las dos posturas que existen aún en el mundo en el que nos movemos. La manera espiritual y la científica que antiguamente se fusionaban y formaban un todo en el que se movían nuestros antepasados son anuladas actualmente debido a la fragmentación que ha dado lugar a ver las cosas por sectores separados sin fijarse en la totalidad de relaciones que conectan todo. Esto trae como consecuencia que el ser humano se sienta como una pieza aislada y suplantable dentro de la dinámica del universo, e incluso lo determina a escalas menores como la sociedad o la familia.

Veremos también la relación y la permanencia de las metáforas del tejido que se usan para explicar en ambas 
concepciones las estructuras que conforman el mundo. El tejido se ha tomado como modelo tanto en el cauce mitológico como en el científico por su cercanía a lo humano y la versatilidad que contiene en sus conceptos y elementos.

En el capítulo tres avanzaremos hacia la contemporaneidad. Veremos cómo se ha formado el tejido cósmico en la ciencia contemporánea, las metáforas construidas alrededor de la teoría para explicar el origen del universo postuladas por los físicos modernos. Se hablará de la física como la única disciplina que no ha renunciado a explicar la totalidad, y aunque tiene ramas que estudian los fragmentos, hay una motivación muy fuerte por encontrar la explicación a los sucesos que tuvieron lugar en el momento en que todo se originó $y$, más importante aún, hallar las relaciones que funcionen para todos los fenómenos que tienen lugar en la realidad.

Se verán, -aunque de manera general por no ser ambición de este trabajo explicar plenamente los postulados de la física-, las principales propuestas que están hoy sobre el tapete. Se hablará de las tramas en la ciencia y en la historia, de la teoría de las supercuerdas y la teoría de las membranas que son puestas ante los ojos de los profanos y que podemos entender gracias a las metáforas, algunas muy relacionadas con el tejido. 
Finalmente en el capítulo cuatro incursionaremos en los mundos digitales estudiando los procesos multimedia y las expresiones textiles junto con ellas. Los nuevos mecanismos de creación y de enfrentamiento con el mundo nos permiten, por medios tecnológicos novísimos, crear productos con un nuevo sentido que es resultado de la época electrónica y computarizada. El textil dialoga con estos instrumentos y máquinas que han traído innumerables posibilidades de expresión.

La creación textil en la era multimedia sigue abordando los senderos del arte pues está presente en los modelos que definen el arte contemporáneo y cada vez se encuentran nuevas posibilidades en el manejo y combinación de sus materiales. La metáfora continúa siendo útil y verdadera: tramas de hilos, luz y sonidos siguen en el escenario y mantienen la cercanía con lo humano. Las fibras y el tejido permiten mantener el lazo con la humanidad sin el extrañamiento que provocan las máquinas y sus procesos.

En otro apartado discurriremos acerca de las manifestaciones textiles y de fibras combinadas con otras disciplinas en el arte contemporáneo; será una pequeña muestra de lo que se está haciendo en el campo artístico respecto al tema. 
Finalmente vienen las conclusiones donde esperamos sentar las líneas de lo que son actualmente los campos donde se desarrollan e interactúan el origen, el tejido, la ciencia y el arte, elementos que siempre estarán presentes en el hacer y el interrogarse del ser humano. 


\section{Capítulo I}

\section{Tejido, texto y trama.}

Estas tres palabras son utilizadas en varios aspectos del discurso humano. El tejer se refiere a entrelazar varios elementos, lo que se logra con un orden regular para unir dichos elementos y finalmente cumplan así su función. Se refiere a componer algo con cierto método y así tener una cosa distinta de los elementos originales tomados en sí mismos. Es unir partes que permanecen distintas pero que estarán totalmente integradas al todo.

El texto -del latín textus que quiere decir propiamente tejer, enlazar- es un conjunto de enunciados coherentes, y une distintos pensamientos para dar forma a un discurso acerca de un tema. También tiene un orden inherente para la construcción. El texto manifiesta un lenguaje y comunica también la estructura de ese lenguaje, sus normas y sus variantes. A partir del texto se pueden definir los significados y a mi ver encierra una parte siempre creativa que enriquece la cultura a la que pertenece.

En el texto se pueden encontrar nuevos significados que no se habían visto a primeras vistas, porque tiene sitios 
secretos o símbolos desde donde se generan estructuras en la red que forma. El texto puede tener varias funciones, una de las más importantes y evidentes es la comunicativa pero también se puede percibir e interpretar de varias maneras, dependiendo del punto de vista del receptor. El texto presenta ante nuestros ojos una red de significación y de identificación con algo que entendemos. También, dice Lotman,

No sólo metafóricamente es posible comparar en este sentido los textos con las semillas de los vegetales, las cuales, como mecanismos que generan información, pueden ser trasladadas a una esfera ecológica ajena, conservando su potencial de germinación, es decir, reconstruyendo la memoria del árbol que las produjo. ${ }^{7}$

El texto se forma de subtextos, que son sentidos entretejidos a la significación evidente y que a la hora de la lectura permiten que el conjunto de significados, tanto los del texto propiamente como los de quienes lo abordan, se sumen y construyan un red con elementos sociales, individuales, simbólicos y culturales en un orden lógico que permite al sujeto sumergirse en el mundo magnífico del pensamiento materializado por el lenguaje. El texto

7 http://www.ugr.es/ mcaceres/entretextos/pdf/entre2/lotman.pdf (Consultado en enero de 2013). 
tiene una lógica delicada pero al mismo tiempo una interpretación múltiple.

Tejido es un participio y se junta con otro participio "texto" y al tejer, la tejedora elabora un texto porque eso quiere decir texto; lo que está tramado. El participio es la forma no personal del verbo que puede recibir marcas 0 géneros, como nos dice el diccionario. $Y$ la persona que los realiza o ejecuta, pone en ellos lo que se necesita para darles significado. Justo esto tienen en común dichos conceptos, en ambos casos se les dota de significado al irlos construyendo.

El tejido tiene dos formulaciones, una que es el acto de tejer donde el tejido se convierte en una trama y otro que es el acto de entrelazar significados, que es propiamente el texto, por lo tanto lo que está tejido es lo que puede leer. Tejer es enunciar. De tal modo el textil está dando una significación que pide ser interpretada. El textil y el texto nos atraen por lo que significan. Veremos que esto tendrá un profundo impacto en las antiguas culturas donde existía una unidad entre las cosas y los simbolismos o significados. Como voy a tratar de cómo se trama el mundo, luego trataré de descubrir cuál es el texto del mundo.

El mundo se trama con los hilos, con las cuerdas, del mismo modo que se entrelazan los significados. Por eso 
textil y texto tienen la misma raíz. La gente cuando teje está formando significados, de modo análogo a cuando discurre en el texto. Ambas actividades contienen en sí la elaboración de algo nuevo, hacer un tejido o construir un texto implica tener un contenido mental previo de muchos elementos que de alguna manera, durante el hacer, se ordenan y organizan de tal manera que exponen, ante el que ve el tejido o ve el texto, una nueva disposición que no existía en el mundo. "Renueva el mundo". Se tejen los hilos y se tejen las palabras para formar la trama. Hay una disposición interna entre varias partes que se ligan.

Así pues, de manera inversa, cuando se busca el significado del mundo, se empieza a buscar cómo está tejido, qué partes lo forman, cómo se relacionan unas con otras, hasta dónde llega cada una. Esto permite descubrir el orden de las cosas y de los símbolos que nos hacen llegar al entendimiento de las causas primeras. Es necesario destejer para saber cómo se tramaron los hilos del texto y del tejido.

Tejer es la metáfora perfecta para describir en varios niveles la conformación del mundo en todas sus expresiones. Tanto el texto como el tejido se mueven y funcionan en varios niveles: se tiene que reconocer los elementos que los forman, es decir, las palabras o los hilos. Cada uno por sí mismo representa algo desde el inicio; luego, se ordenan de cierta manera, se sigue una 
técnica que permite el enlazamiento, de manera correcta, de hilos y palabras.

Es entonces que se pueden imbuir significados nuevos por el acomodo de elementos disponibles y finalmente se da la comprensión porque se han construido modelos mentales que corresponden al ámbito del sujeto. A partir de ahí se muestran como un llamado de atención para quien lee el texto o el tejido, quien va a ser el que manifestará los efectos de lo transmitido y recibirá el significado según la representación mental personal.

Tramar nos permite construir esos nuevos sectores a los que se dirige el conocimiento humano. La trama es la representación de los acontecimientos unidos para el impacto de la sensibilidad y la transmisión del conocimiento. Cuando tramo los hilos en cualquier campo del saber, represento la trama de la creación; la trama es lo que resulta de tejer: el objeto, pero también la representación. Ahí en la trama es donde se entrelazan los significados y se representan los acontecimientos del cosmos. Cada trama tiene su diferente enlace, según el ámbito al que pertenezca.

Intentaremos transitar por aquellos tiempos primigenios donde se inició la construcción de todo lo existente, encontrar sobre todo una coincidencia en la manera de expresar la creación, y ver si la manera de construir los conceptos que explican ese origen acaba inevitablemente 
en la metáfora de tejer el mundo, con hilos y cuerdas que construyen lo creado. De diferentes maneras, pero ese tejer siempre tiene un lugar en el origen, por ser una de las actividades más antiguas y que han acompañado al ser humano desde siempre.

En este trabajo haremos un acercamiento a esos conceptos y metáforas tanto en la cultura azteca, de la que no quedan mas que resabios, pero cuya riqueza ha sido traída a la luz por los arqueólogos, como en la cultura maya, que sigue viva en los diferentes grupos que siguen practicando sus tradiciones, adaptados a todo lo que les ha sucedido desde la llegada de Colón y que además han sido objeto de intenso estudio por los arqueólogos y etnógrafos, para finalmente llegar a los planteamientos de la física contemporánea que propone teorías para la explicación de todo lo que existe, y cuyos enunciados cada vez me parecen más cercanos a una concepción mística del mundo pero sustentada científicamente.

Cada cultura tiene sus propias historias de cómo fue creado el universo y todo lo que nos rodea, incluyendo a la humanidad y por esas historias podemos aprender mucho de los pueblos que las crearon. De la misma manera, en el mundo contemporáneo mostramos nuestro interés científico y elaboramos teorías que permiten explicar cómo funciona el universo, de dónde venimos y a dónde vamos, por qué el mundo es cómo es; y podemos 
darnos cuenta que esas son las mismas preguntas que se hicieron los individuos que vivieron en las civilizaciones pasadas. Y lo que nos interesa es mostrar cómo, en ese transcurrir del tiempo, se han utilizado las mismas metáforas relacionadas con el tejido. 


\section{1.-Identidad: misticismo y ritual.}

La identidad de un pueblo comienza con elementos que unifican ciertas líneas de pensamiento que rigen su vida. La influencia de dichas líneas sobre la vida cotidiana, es lo que determina su agrupación como parte de un grupo social. Generalmente, en los pueblos antiguos, la religión era el agente aglutinador de la actividad social. La reverencia ante los hechos naturales que no se podían comprender, el suponer que había "algo" o "alguien" que movía las fuerzas que provocaban los fenómenos inexplicables, naturales o humanos, hizo que se formara la idea de la existencia de algo superior. La necesidad del ser humano de saber que todo está bajo control, -aunque no sea "su" control-, de que el caos no es totalmente arbitrario, es lo que lo lleva a la construcción de la idea de lo divino.

Lo superior, es decir la divinidad, tiene que ser el modelo que les dice cómo conservar el orden en el mundo. Es quien enseña cómo se deben hacer las cosas, en base a qué principios deben comportarse los individuos, cómo se debe estructurar una sociedad y cómo las cosas cotidianas representan un evento importante que hace 
que el ser humano forme parte de ese proceso creativo del mundo y la naturaleza.

Si nos acercamos un poco a considerar cómo ven a los dioses los egipcios, los judíos, los romanos, los prehispánicos, podremos ver que cada cultura construye su identidad a partir del recuento de acciones realizadas por una divinidad en un tiempo que trasciende la realidad que los seres humanos viven en su momento. El acercamiento a lo divino se da por medio de la asimilación de ciertas acciones, de objetos que no son solamente objetos, sino que contienen en sí una fuerza significante que les da su carácter de sagrados.

Esos conceptos ayudan a comprender mejor las acciones del presente. Sobre todo si echamos una mirada al estudio del pensamiento tradicional. Es a Mircea Eliade a quien se debe la siguiente agrupación de los elementos que funcionan como fundamento para la construcción de la identidad de los pueblos en las sociedades arcaicas:

1.- los elementos cuya realidad es función de la repetición, de la imitación de un arquetipo celeste;

2.- los elementos materiales como las ciudades, templos, casas, cuya realidad es tributaria del simbolismo del centro supraterrestre que los asimila a sí mismo y los transforma en "centros del mundo"; 
3.- por último, los rituales y los actos profanos significativos, que sólo poseen el sentido que se les da porque repiten deliberadamente tales hechos planteados $a b$ origine por dioses, héroes 0 antepasados. $^{8}$

Cada cultura encuentra su propio modo de tomar dichos elementos y apropiarse de ellos por completo integrándolos en su vida terrenal. En el tiempo originario, alguna deidad realizó los actos necesarios para que la vida tuviera un comienzo, para que la naturaleza funcionara, para que los seres humanos existieran tal y como son ahora y para que la sociedad funcionara como tal y sintiéndose parte de la totalidad.

Pero no sólo en la sociedad funciona de esa manera, también el individuo tiene que sentirse a sí mismo como parte de esa comunidad, como reflejo y creación del dios primordial, y es por eso que se puede identificar como integrante valioso y único del grupo, sentirse parte de esa identidad. Los arquetipos son el modelo a seguir, las primeras acciones divinas se encaminaron a la creación del mundo y de los seres humanos.

Los modelos celestes son la inspiración para cualquier establecimiento en la tierra. El diseño del templo, de la ciudad, incluso de las casas, repite un modelo dado por

${ }^{8}$ Eliade, M. El mito del eterno retorno, p. 15-16. 
los dioses. Las acciones de fundación en la tierra, equivalen a una nueva creación. Lo que el humano toca o habita, se vuelve parte del orden divino, mientras que las regiones lejanas que no han sido descubiertas 0 conquistadas, pertenecen aún al caos. El individuo participa del hecho primigenio de la creación en la tierra y sobre la naturaleza.

Los representantes del culto repiten aquellos hechos primigenios, y de esa forma son parte de ese hacer, de ese crear que les ha dado origen. Dicha repetición conecta la acción humana con la acción divina, le da sentido al mundo de las personas, permite que todo se dirija a la unidad con el cosmos. Todo es asimilado al modelo divino particular de cada grupo. Es así que se ha construido la identidad de las culturas antiguas y es la manera en que se ha dado forma a la sociedad contemporánea.

Los segundos elementos que menciona Eliade son evidentes en la construcción material, cercana, de lugares donde habita lo divino; la traza de las ciudades emula la traza del mundo supraterrenal en el que la deidad habita, los templos son su casa en la tierra y las casas tienen un lugar sagrado que permite a sus habitantes tener un canal de comunicación con la deidad.

Todos esos lugares representan el centro del mundo, un lugar de partida originaria que permitió el poblamiento de 
la tierra. Cada uno de esos elementos contiene en sí su parte sagrada, la significación agregada a su mera construcción arquitectónica. Cada parte de esos lugares es un enlace con lo divino, que abarca todo lo creado, y por tanto permite a los que en ellos entran o habitan sentirse parte de esa comunidad, tener una identidad común; cada habitación repite o representa la totalidad del cosmos. Cada lugar que se construye sobre la tierra, se hace con elementos tomados de la naturaleza y repiten la casa divina, el hogar en el que el individuo puede sentirse cobijado y albergar a la divinidad; donde la relación se vuelve directa por encontrarse a resguardo. Cada parte de dichos lugares se convierte por medio del ritual en algo significativo, supera la materia y a la vez materializa la esencia divina.

Dichos lugares están ubicados en puntos estratégicos para alinearse con las fuerzas que provienen del cosmos. Los solsticios, los equinoccios, las conjunciones, las traslaciones, la progresión de los astros, son visibles en esas construcciones, además de que muchas de ellas son el receptáculo de las influencias planetarias que ayudarán al ser humano a ponerse en sintonía con el universo, a tomar el lugar que le pertenece dentro de la estructura universal. Esto se ve claramente en los últimos estudios que han hecho los astrofísicos en las pirámides y 
construcciones antiguas pertenecientes a las culturas prehispánicas.

Los elementos terceros, incluyen ya la conciencia del individuo, un hacer para repetir deliberadamente la acción divina; rituales, símbolos, formas expresadas en el actuar cotidiano conducen al individuo a su integración con la comunidad y al mismo tiempo con el creador de todo.

Las cosas que no se ven, los sentimientos, los pensamientos, la comprensión de la vida, etc., se organizan en formas místicas, es decir, en fórmulas religiosas, en ejercicio de poderes, en repeticiones mágicas. No podemos ver lo que la gente siente, lo que la gente entiende, necesitamos una forma de expresión para esas áreas de la vida que no están a la vista. Comienzan así los rituales para acercar al humano a lo divino y permitirle ser parte de ese mundo integral que incluye a la divinidad y al ser humano como parte de lo existente.

Los ritos van encaminados a la repetición simbólica del origen porque es necesario construir formas que expresen ese contenido mítico en algo más cercano, que presenten lo invisible de una manera que todos puedan percibir, que permitan el acercamiento a algo tangible, material, a algo común a todos.

La eterna pregunta sobre el origen de todas las cosas se responde en el caso que aquí tratamos con el relato de algo muy lejano, del inicio de los tiempos, de lo cual 
ningún individuo fue testigo, sólo los dioses estaban y cuando se creó al ser humano, el mundo ya estaba completo, la naturaleza ya funcionaba. El ser humano llega a habitar un sitio ya ordenado, y se le permite ser parte de esa creación cuando va a lugares desconocidos e influye en ellos imponiendo su cultura, su identidad, su posibilidad de ente creador.

Ésa es la posibilidad de la humanidad de utilizar lo que de divino se le permite tener. "...la transformación del caos en cosmos por el acto divino de la creación." ${ }^{9}$ Es poner un orden distinto donde sólo imperaba el orden natural. Pero ese orden natural no le pertenece del todo a la humanidad, tiene que construir uno que le sea propio, imitando la acción de los dioses, y de esa manera elaborar uno que le permita el nexo con la totalidad de lo existente.

La correspondencia de los mundos que forman el universo es importante. Tal como se creó el mundo por los dioses, así tiene que transcurrir el hacer en el mundo de los seres humanos. Poniendo un ejemplo apropiado para el desarrollo de este trabajo; podemos decir que el acto de tejer fue enseñado por los dioses en un tiempo primordial, y tal como lo enseñaron los dioses tiene que ser repetido en la tierra por las mujeres tejedoras.

${ }^{9}$ Eliade, M. Op.Cit., p. 19. 
Esa creencia en la repetición y emulación de los actos divinos forman la mística de las culturas. Y esa búsqueda de ser como los dioses, tiene que repetirse también en el interior del individuo, El cielo es el ejemplo de la construcción del mundo de los humanos, pero también los sentimientos y las acciones divinas, son el hilo conductor de la interioridad humana.

Los sentimientos, los pensamientos, incluso las emociones están contenidos por ciertas normas establecidas en un principio por los dioses y perpetuadas por los encargados del culto. Dichas normas construyen la identidad desde el interior de cada individuo, garantizando su pertenencia al orden que se ha construido en el mundo que habitan. Si no se lleva a cabo lo anterior, el mundo caerá en el caos, contrario al orden divino. Por medio del alineamiento al sendero mostrado por los dioses, su supera la inmediatez.

"Lo sagrado, trascendental y ejemplar, obliga al hombre religioso a salir de las situaciones personales, a superar la contingencia y lo particular y a llegar a los valores generales, a lo universal" 10

${ }^{10}$ Allen, Douglas. Mircea Eliade y el fenómeno religioso. 
La experiencia de lo sagrado ha abierto el camino al pensamiento sistemático. Cuando se construye un mito, se está formando una sistema lógico en su estructura, que contiene un discurso que si bien puede no parecer transparente, está totalmente articulado y contiene en sí los elementos que explican y justifican el ser, lo real y sus contrapartes. Para la sociedad que crea el mito, éste contiene la reflexión profunda acerca de cómo las cosas fueron creadas, explica la presencia del ser humano en la tierra, las fuerzas de la naturaleza, el orden y el caos, la acción divina y su hacer determinante sobre el cosmos, etc.

El mito va hacia las respuestas de las preguntas que cada cultura e individuo se ha hecho a lo largo de la historia, por lo que podemos afirmar que en ese sentido podría considerarse al conjunto de mitos pertenecientes a un pueblo como un sistema filosófico rudimentario.

De una manera general se puede decir que el mito, tal y como lo han vivido las sociedades arcaicas, 1.-constituye la historia de los actos de los Seres sobrenaturales; 2.-que esta Historia se considera absolutamente verdadera (porque se refiere a realidades) y sagrada (porque es obra de los Seres Sobrenaturales); 3.-que el mito se refiere siempre a una creación, cuenta cómo algo ha llegado a la existencia, o cómo un comportamiento, una institución, una manera de trabajar, se han fundado; es ésta la razón que los 
mitos constituyan los paradigmas de todo acto humano significativo; 4.-que al conocer el mito se conoce el "origen" de las cosas y por consiguiente se llega a dominarlas y manipularlas a voluntad, no se trata de un conocimiento "exterior", "abstracto", sino de un conocimiento que se "vive" ritualmente, ya al narrar ceremonialmente el mito, ya al efectuar el mito que sirve de significación; 5.que de una manera u otra, se "vive" el mito, en el sentido de que se está dominado por la potencia sagrada, que exalta los acontecimientos que se rememoran y se reactualizan. ${ }^{11}$

El mito trasciende los hechos terrenales, pero necesita de acciones humanas para sostenerse, el ritual entonces, es necesario para poder tener contacto directo con esa realidad de más allá. Además, el ritual se construye como un cauce que permite a los humanos tener comunicación con el plano superior y de cierta manera establecer esa retroalimentación que debe existir entre la divinidad y la humanidad.

Los símbolos también son importantes en ese sistema de pensamiento, un símbolo contiene mucho más que su mera figura, mucho más que el dibujo o color que lo representa, es el resumen y la síntesis de algo mucho más complejo, es una conexión rápida y directa de la

${ }^{11}$ Eliade, Mircea. Mito y Realidad, p. 11. 
mente humana con la divinidad y que permite la percepción sensible de una realidad trascendente.

Al ver el símbolo, cualquier individuo que tenga la clave perteneciente a la comunidad puede descifrar su contenido y reafirmar su pertenencia, además de sentir que se está cumpliendo con las disposiciones o ejemplos divinos. Es un recordatorio de algo que pertenece a otro plano, que se sale del mundo cercano y trasciende los límites de la cotidianeidad aunque se proyecte en ella.

Los símbolos pueden revelar una modalidad de lo real o una estructura del mundo que no son evidentes en el plano de la experiencia inmediata, de acuerdo con Mircea Eliade. Todo eso que está invisible ante nuestros ojos; la manera de apreciar el mundo y a los otros tanto como a sí mismo, la relación que se tiene con la naturaleza y los animales, el vínculo que se mantiene con lo divino, tiene que ser expresado de alguna forma visible.

Se establecen entonces dichos ritos y símbolos que a cada paso recuerden la pertenencia a la cultura. En los actos cotidianos se establecen también pequeños ritos, fórmulas mágicas integradas al quehacer de todos los días y también símbolos que se repiten en expresiones plásticas que nos recuerdan aquel hacer primigenio.

En las culturas antiguas toda actividad humana obedece a un prototipo divino. La danza, la curación, el encender el fuego, la caza, el nacimiento de un niño, el tejer, etc. Un 
ser primordial enseñó las costumbres y la manera de hacer las cosas; las normas básicas que sostienen el orden en el universo y que deben ser repetidas en el actuar cotidiano para evitar que se destruya el mundo.

El tejido no es la excepción y en la mayoría de las antiguas religiones, las diosas enseñaron el tejido a las mujeres. Los instrumentos utilizados en el tejido son construidos siguiendo la manera primordial. Si cada acción que el individuo realiza en la tierra es un acto que emula la acción divina, entonces cada acto tiene importancia; el ir a escoger la madera que forma el telar o el huso, contiene un acto mágico y de ofrecimiento a los dioses para continuar con la conexión divina, el cosechar las plantas de las que provienen las fibras no es un acto simple, es poner la acción humana sobre los productos de la naturaleza tal como los dioses imponen su acción sobre todo el universo; el hilar la fibra crea algo nuevo, de algo disperso se crea un hilo conductor que llevará a la creación de mundos nuevos que contendrán el simbolismo que ordena la existencia del ser humano. Los símbolos tienen un contenido mágico que nos recuerda algún hecho o periodo del tiempo divino, del acto de la creación, de los elementos de la naturaleza que tuvieron alguna importancia en la instauración del orden de las cosas. El repetir esos símbolos en la plástica decorando vasijas o diseñando tejidos recuerda al que 
usa dichos objetos que no sólo es el objeto mismo sino que tienen contenido divino, y al utilizarlos en la cocina o en las prendas de vestir no sólo satisfacen una necesidad, sino que permiten al individuo reconocer su identidad, su lugar en el mundo, su pertenencia a la cultura en la que se encuentra.

Al repetir los símbolos en los objetos cotidianos se repite lo que ha sido mostrado por los dioses como un recordatorio de la acción que debe hacerse para sostener el mundo. $Y$ esa repetición lleva al ser humano a vivir en el presente pero desvalorizando el tiempo actual; el instante presente sólo tiene valor en cuanto es emulación del instante primero en que los dioses actuaron.

Al repetir el tiempo originario por medio del ritual o el símbolo, el misticismo se muestra como parte de la vida, no existen los siglos anteriores, y al mismo tiempo, todo está ocurriendo en ese momento primigenio en que se vive infinitamente. Es la abolición continua de la Historia, como dice Mircea Eliade. ${ }^{12}$ Dicha abolición permite al ser humano renovarse continuamente, hacer de cuenta que vive en ese tiempo originario, divino, significativo.

El tiempo normal, el de lo humano, carece de esa riqueza de significado, y cada momento donde se realiza un ritual es un momento que pertenece al tiempo sagrado, donde el ser humano deja de ser un simple individuo mortal y se

12 Eliade, M. El mito del eterno retorno, p. 30. 
convierte en parte del cosmos, en lo que verdaderamente es, parte de la divinidad. El tiempo es regenerado por los rituales que se hacen necesarios para darle el significado mítico.

La mística en las sociedades arcaicas se expresa en objetos y símbolos cercanos. No existe esa separación moderna de lo místico y lo material. Se consigue la identidad de la comunidad con el cosmos pero también la identidad consigo misma. El individuo es dios creando el mundo en cada rito, perpetuando el funcionamiento del universo con esas acciones que le enseñaron los dioses.

El tiempo debe ser regenerado, es decir, vuelto a vivir. No es un tiempo que se va y no existe más, es precisamente la repetición eterna del tiempo originario por medio del ritual lo que permite que ese momento primigenio, el momento del origen de las cosas y de las actividades del ser humano, vuelva a repetirse. ${ }^{13}$

Esto trae como consecuencia que la humanidad pueda regenerarse y empiece como si fuera el primer momento de existencia; la historia, por tanto puede volver a escribirse, comienza de nuevo. Los ciclos son importantes, pues dejan que la humanidad parta del estado originario, con esa pureza que da la regeneración

13 Idem. Para profundizar sobre el tema véase la reflexión que hace Eliade sobre el tiempo. 
y la conexión con lo sagrado para dirigirse de nuevo hacia lo profano, pero desde el núcleo divino que le dio vida.

Los individuos tendrían entonces claro de dónde vienen y a dónde se dirigen, la incertidumbre disminuye y pueden actuar sabiendo que sus actos llevarán a la consolidación y permanencia del mundo. Hay un ciclo que se repite y avanza, pero también en ese movimiento hay oportunidad de dejar su marca, la huella de su creatividad y de su importante acción sumada al ejemplo de los dioses.

En esas sociedades arcaicas, la vida se sustenta en lo sagrado, lo sagrado que es un universo creativo, generador absoluto de la vida, pero también de las acciones que permiten la continuidad de dicha vida. La regeneración se da en varios niveles: en lo social, por medio de los ritos colectivos llevados a cabo por el chamán o el rey; en las casas de cada uno, al cumplir las fórmulas de cada actividad doméstica; y en lo individual al realizar los sacrificios en el propio cuerpo porque conectan al individuo con la divinidad. La acción humana es importante para los dioses y para el mundo. Esta conciencia construye otro carácter en dichas comunidades, las dota con rasgos que apenas podemos vislumbrar desde nuestra postura actual en el mundo.

El tiempo es un concepto clave para ubicar al ser humano. Tanto en las sociedades arcaicas como en las modernas, la comprensión del funcionamiento del tiempo 
nos da las pistas para la explicación de la existencia de la humanidad y su mundo, del cosmos, de la naturaleza. En las sociedades arcaicas, dice Eliade, el tiempo es cíclico, se repiten los momentos y todo pertenece a un arquetipo que muestra cómo debe funcionar el mundo no sólo en el plano material, sino también los sentimientos ante las cosas; e incluso las actitudes que se mostraron en el instante mismo de la creación, fueron las que tuvieron los dioses al producir situaciones específicas.

El mundo se renueva cíclicamente con los rituales de Año Nuevo, generalmente se hace un retorno al caos que existía antes de la creación primigenia y de ahí surge el mundo y el individuo purificados, listos para actuar de nuevo en el mundo recién hecho. Esa renovación implica la muerte de lo anterior, una muerte del ser humano, del orden cotidiano de las cosas, del mundo como se había conocido hasta ese momento, incluso la muerte de la propia divinidad. Para renovarse hay que morir. $Y$ esta renovación afecta en lo más profundo de la psique de estas culturas antiguas, porque no es una renovación superficial o ficticia, es la renovación de todo lo que existe a un nivel que abarca sentimientos y percepciones en lo más interno del ser humano.

En la sociedad actual el momento histórico es el que explica la existencia de las cosas como son, pero es necesario hacer notar que, como dice Mircea Eliade, hay 
también un mundo de sentimientos, de deseos, de sueños, en fin, de una existencia individual que no puede ser explicada por dicho momento y que tendremos que explicar de otra manera, por cuanto pertenece a otro tipo de conciencia que proyecta al sujeto fuera de ese mundo histórico.

Esa separación ha provocado el desfase que podemos ver claramente en nuestros tiempos modernos. A todos los niveles se actúa dentro de una fragmentación y esto provoca miedos, incertidumbres; un no saber qué hacer con nuestra existencia individual frente a la existencia colectiva, con nuestras creencias personales dentro de una gama casi infinita de posturas, etc. ¿Qué es lo seguro a lo que podemos aferrarnos? Pareciera que nadie tiene la respuesta correcta. Cada uno de nosotros existe y actúa por su parte en el mundo hecho de fragmentos. Cada quien tiene que buscar su respuesta. La responsabilidad casi es demasiada para los humanos de hoy en día.

El ser humano atado al cabo de la historia pierde sentido junto con la historia, en tanto que el hombre cíclico, "es libre de no ser ya lo que fue, libre de anular su propia historia mediante la abolición periódica del tiempo y la regeneración colectiva". ${ }^{14}$

14 Idem., p. 56. 
La dicotomía mito-logos es una de las múltiples divisiones que existen y se presenta hoy como una postura que la misma historia impone, y esta historia que lo impone, paradójicamente es producto de la dicotomía. El pensamiento actual se inclina hacia los datos duros, pero vemos que no son suficientes para explicar muchas cosas. Es necesario recuperar el espacio de lo sagrado o de lo contrario se tiene que aceptar una razón que no es lógica, una lógica no racional, que no está en sintonía con el ser, sino con la historia, una historia con destino incierto, una historia fuera de control por no estar ligada con lo permanente y eterno, con la imposibilidad de aproximarse a lo que relaciona las cosas y los seres que existen.

Según Eliade, el hombre actual "se sabe y se quiere creador de la historia", a diferencia del hombre arcaico que "no la consideraba como una categoría específica de su propio modo de existencia". 15

Visto de esta manera, el ser humano, como ser histórico, pierde todo sentido, porque la misma historia pierde sentido. Sólo tiene valor y existencia real cuando está inmerso en los arquetipos sagrados, cuando se sumerge en el tiempo del ritual y le da pleno significado a su existencia dentro del mundo y la naturaleza.

15 Ibid. p. 58. 


\section{2.- Creación, producto y sentido}

¿Por qué el ser humano desarrolló conceptos que explicaban la creación del mundo? En la fragilidad de su conciencia, el ser humano necesita de dónde asirse, no le basta su propio ser existiendo ante fuerzas tan poderosas como las que atestigua en su entorno primitivo. Guiarse sólo por el instinto provoca un temor primordial; la razón busca explicaciones que puedan darle la certeza de que es algo más que otro elemento prescindible de la naturaleza. La humanidad no puede vivir en el caos, tiene necesidad de buscar cierto orden que garantice que su existencia tiene sentido. Necesita tejer, construir el texto, elaborar la trama de su vida. Por eso comienza a construir un mundo superior desde el que se dé sentido a las cosas y a las acciones; comienza así la religión.

Dice Mircea Eliade que es una pena que no exista otra palabra distinta a la de "religión" para designar la experiencia de lo sagrado, porque esta palabra tiene mucha historia tras de sí, sin embargo considera que no tiene la suficiente amplitud para el significado que se busca. 
Pero quizá es demasiado tarde para buscar otro nombre, y "religión" puede ser una palabra útil todavía, siempre y cuando tengamos bien en claro que no implica necesariamente creer en Dios, dioses o espíritus, sino que se refiere a la experiencia de lo sagrado y, por lo tanto, está relacionado a la idea de existir, de tener significado y de lo verdadero. ${ }^{16}$

Este tener significado que menciona Eliade, es una constante en el desarrollo de la conciencia del ser humano. Desde los tiempos primitivos se indaga por el significado de las cosas, de los eventos, de las emociones y de los pensamientos. Había que construir un mundo desde el que se pudiera explicar la existencia y el quehacer humanos, un mundo en el que la acción del individuo pudiera ordenar el caos y por tanto darle poder sobre las cosas que existían, además de ver la diferencia entre lo que podía controlar y lo que escapaba de su control.

Este proceso del pensamiento dio como resultado el desarrollo de la mente, el acostumbrarse a pensar en un orden y no vivir permanentemente en estado de temor dentro de un mundo caótico y fuera de control, por tanto, ayudó a que el ser humano desarrollara más habilidades.

${ }^{16}$ Eliade, Mircea. La búsqueda, p. 7. 
La creación de seres divinos, arquetipos que actuaban en un nivel en el que la humanidad no podía, tuvo como resultado la imitación de dichas acciones sagradas en el mundo cotidiano. Esto le dio tranquilidad interior al ser humano, pues ya no estaba sin saber cómo actuar en el mundo, sino que tenía un modelo para repetir en situaciones de riesgo e incertidumbre. De ese modo su mundo quedaba bajo la protección de algo superior, y por medio de las acciones humanas esta protección estaba garantizada. Lo cotidiano se volvía sagrado, por tanto tenía un significado y ese significado completaba el mundo, le daba sentido.

La experiencia de lo sagrado, al dejar al descubierto existencia, significado y verdad, en un mundo desconocido, caótico y temible, preparó el camino para el pensamiento sistemático. ${ }^{17}$

El estudio de las creencias, mitos y ritos de cualquier cultura del mundo, nos da la posibilidad de ingresar en las situaciones de vida que se vivían en un momento determinado, no es solamente el estudiar la religión, sino que a través de las estructuras construidas, se puede descifrar lo que vitalmente movía a ese grupo social y aún en las sociedades que se sienten liberadas de la religión,

17 Idem., p. 8. 
se pueden identificar elementos, puestos de nueva manera, pero que pertenecen a lo sagrado. Dice Eliade que el hombre no puede reducirse a lo racional, porque siempre tiene sueños, enamoramientos, ficciones, y construye mitos para moverse en el mundo.

Lo sagrado pertenece al ser humano, y como tal, no puede separarse de él. Lo sagrado varía cuando se estudia en un contexto grupal o en un contexto individual. En el nivel social, se construyen estructuras míticas dependiendo del nivel de desarrollo, y a nivel individual, el sujeto tiene su interpretación muy personal de dichas estructuras, a las que suma sus emociones, sus convicciones y sus experiencias personales. Además, lo sagrado puede renovarse, pues obedece a la situación en la que se mueve cierto grupo social.

La destrucción de los mitos lleva a una situación que se puede ver como peligrosa socialmente pues acaba con modelos culturales aceptados por largo tiempo. $Y$ esto se puede ver en todas las esferas de la vida humana. En el arte, la innovación de cada nueva corriente estética, acaba con lo aceptado y provoca una resistencia al abandono de las formas anteriores. Cada innovación implica una nueva forma de concebir lo sagrado. Y la experiencia artística, como dice Eliade, es lo que más se parece a la religión en cuanto a la experiencia de lo sagrado. Es ahí donde se puede ver con claridad dicha 
experiencia y $\sin$ las limitantes que ponen las implicaciones que inevitablemente carga la palabra religión.

Ahora bien, referirse a lo sagrado no significa que nos situemos en un plano abstracto, donde no quepa nada sino la especulación. Al contrario, para entender en su totalidad el significado de dicha experiencia haría falta ver el fenómeno desde distintas perspectivas.

Pongamos por ejemplo una obra artística: hacen falta muchas condiciones y el estudio de las mismas para llegar al conocimiento real de una obra. Si conocemos las condiciones sociales en las que se ubica, y la historia personal del artista, además del modo como enfrentaba los materiales con que trabajó; si vemos en qué punto del arte se acomoda, reflexionamos sobre el secreto que guarda, analizando la reacción del espectador, el tipo de espacio en el que se muestra, la inserción social que implica, etc., logramos un acercamiento mayor para entender el significado. Puede hacer falta la labor de varios especialistas conjuntando esfuerzos para enfrentar la complejidad del fenómeno.

Pero tanto la experiencia estética como la religiosa, van más allá del análisis de todos esos aspectos. El contenido espiritual es el que da la verdadera comprensión del sentido de sus productos. Una obra de arte revela su 
significado sólo cuando es percibida en lo que es, en su propio universo, en su presencia ante el mundo.

La creación es lo que se dice del artista y de los dioses: ambos son creadores. El producto es el mundo, pero también es la obra. La obra la hacemos porque tiene un sentido de lo humano, y la creación del universo debe tener un sentido, debe ser una obra de arte. Se dice que el demiurgo, el supremo arquitecto, la divinidad, es el creador de algo que no existe, en ese sentido es el supremo artífice, por tanto, el individuo que repite esa actividad es un artista y creador, en su escala, de obras que no existían antes.

La concepción mítica de la creación en todas las sociedades antiguas, tiene que ver con los dioses primordiales, dioses originarios que no crean con sus manos el principio del mundo, sino con sus palabras, soplo o pensamientos. A los otros dioses, secundarios, sí les es dado trabajar con su cuerpo para crear todo lo existente en ese cosmos primordial. Ellos pueden modelar arcilla, llevar los alimentos, construir seres con elementos tomados del cosmos y que fueron puestos a su disposición por los dioses primordiales. La labor por antonomasia de los dioses es la creación, el establecimiento del orden del mundo por medio de reglas y acciones específicas para cada aspecto de la existencia. 
En las sociedades arcaicas la raza humana participa de ese orden y contribuye a la continuación de lo creado por los dioses, la acción humana es imprescindible para el funcionamiento del cosmos y su acción se desarrolla en dos planos, no solamente en el plano físico donde la acción se lleva a cabo materialmente, sino en un plano simbólico donde todo adquiere significado. El individuo de esas sociedades tiene claro el papel que juega en el mantenimiento del orden universal.

El progreso en las culturas lleva al olvido de lo primordial $y$ al repetir el rito para reafirmar el mito, se mantiene siempre una parte conectada a lo originario. El mantenimiento del mito a pesar del cambio en las condiciones sociales o materiales, y su adaptación a la evolución de la sociedad en la que se da, permite a sus integrantes tener el sentido de identidad y pertenencia a esa parte del cosmos y dar la importancia a su hacer en el mundo para la conservación del orden universal primordial.

Cuando se ejerce la voluntad creadora se da vida a un producto: los dioses hicieron surgir el mundo, que es el producto de su creación. El ser humano también crea esos productos que aparte de sus particularidades físicas y materiales contienen dentro de sí un sentido que puede ir más allá de su utilización para la vida cotidiana. El sentido simbólico y mítico de repetición del orden 
universal es puesto en el producto siguiendo ciertas técnicas que están establecidas para asegurar el éxito en el resultado.

Sobre todo en el arte, el individuo pone en juego toda su habilidad creadora partiendo de los materiales que tiene a su disposición, pone su voluntad y su imaginación a trabajar para dar a dichos materiales que están inertes antes de la intervención, un sentido. El sentido es puesto en la materia, proveniente de la mente del artista-inventorcreador. Pero en cuanto la obra es puesta ante los ojos de los demás, cambia el sentido de ésta. Cobra una dimensionalidad que no tenía cuando salió de las manos del creador.

Así como sucede con el universo, que cuando es puesto a la vista del sujeto, cambia en cuanto que es percibido de diferente manera y sus intervenciones modifican lo que le es dado por los dioses aunque continúa ligado a lo divino al volver sagrada cada acción humana, así el producto artístico queda ligado indisolublemente a su creador, pero siempre tendrá la posibilidad de enriquecer su sentido con la percepción que de ella tiene quien la recibe.

Tomando como ejemplo las sociedades antiguas mesoamericanas y poniendo sobre la mesa el tema que nos ocupa, podemos saber que el tejido no se hacía sólo para producir una prenda, sino para dar o descubrir un sentido. El dibujo, patrón o diseño que adornaba lo tejido, 
tenía un simbolismo que la mayoría de los habitantes podía leer. Las grecas no eran sólo grecas, los giros no eran sólo imaginaciones puestas en la tela. Significaban. El contenido que esos dibujos le daban tanto al que veía la prenda como al que la portaba, era un recordatorio permanente de su conexión con los dioses y la naturaleza.

Y no únicamente el dibujo remitía al tiempo primordial, también las técnicas tenían un sentido que se transmitía como una actividad enseñada directamente por una diosa a la primera mujer. La técnica está consignada en el producto. Ahí, en la elaboración del producto, se encuentra depositado el aspecto práctico del mito. No es un producto interior, es algo tangible y perteneciente a la tejedora. Ahí podemos ver el aspecto significativo y material del mito. No es un rito como el del bautismo o la iniciación, donde el sujeto cambia una vez completado el ritual, sino que en el caso del tejido, hay un producto significante que surgió del cumplimiento de los diferentes aspectos de la actividad. La tejedora repite la actividad que le enseñaron los dioses para incidir sobre el mundo. Creación objetiva donde no sólo se crea, sino que se transforma el mundo.

Podemos dar seguimiento al aspecto práctico y mitológico en el proceso del tejido. Las formas sociales determinan y a su vez son determinadas por esas actividades 
enseñadas por los dioses. Todavía, en los grupos indígenas que practican el tejido, podemos ver el proceso seguido para la transmisión de las técnicas, aunque ya ha perdido mucho de su significado sagrado. Al enfrentarse a la hora del tejer, la mujer debe tomar una posición corporal exacta, aprendida desde niña para adquirir la flexibilidad que se requiere para manejar el telar. Es colocar el cuerpo adecuadamente para prepararlo para la gran tarea que se llevará a cabo. No es una postura natural para las mujeres de nuestra cultura occidentalizada, la práctica permite el acomodo de los músculos y huesos para poder estar tejiendo varias horas hincadas en el suelo sin molestias manejando el telar de cintura. Las mujeres mayores enseñan a las niñas, así como la primera vez que se tejió en el mundo cuando la diosa enseñó a la primera mujer; no es una enseñanza sistematizada, está basada en la observación. Los instrumentos están listos, ya se ha preparado el hilo, y el diseño depende de la prenda que se va a tejer. Algunas veces se tejerá para alguien que toma parte en una ceremonia específica y los dibujos tienen que corresponder al significado de ésta. Se tejen en la tela las fuerzas de la naturaleza estilizadas en forma de grecas, líneas o figuras; todo para favorecer la atención de los dioses a los que se invocará en esos rituales. Otras veces, sin embargo, el tejer obedecía a la imaginación de 
la tejedora y a la inspiración que los dioses le enviaban. Surgían de sus manos nuevas interpretaciones de la naturaleza o de símbolos pertenecientes a lo divino.

Como dijimos, estar tejiendo por un lapso largo de tiempo exigía mantener una postura incómoda para nuestros estándares contemporáneos, pero el entrenamiento desde la infancia permitía al cuerpo tejer durante horas. De hecho, el arrodillarse es una postura común entre las mujeres indígenas utilizada para muchas de sus actividades, por ejemplo moler en el metate, y eso permite adoptar esa posición corporal hasta edades avanzadas. ${ }^{18}$

En cualquier actividad que las mujeres realizan, se puede ver un cierto tipo de movimiento, una singular manera de manejar su cuerpo para desplazarse. Los colores también tenían un significado simbólico. Los dioses, las regiones del cosmos, los astros, los elementos, cada uno correspondía a un color determinado. $Y$ el portador de dicho color atraía las bondades de sus características.

El simbolismo de los elementos que se utilizaban al tejer iba más allá de sus apariencias físicas. Antiguamente los hilos de la urdimbre eran la lluvia que caía verticalmente sobre la trama horizontal, es decir, sobre la tierra; y al juntarse producían la cosecha, el producto que mantenía

\footnotetext{
18 Marks G., Patricia. Tejedoras: Generaciones Reunidas. En este libro se hace un interesante trabajo de campo analizando el movimiento y la postura de las tejedoras mayas de Chiapas.
} 
a la comunidad. $Y$ en el telar, la tela era un nuevo producto surgido de la interacción de elementos muy diferentes. Así como la lluvia fertiliza la tierra para que crezca el maíz, así el hilo de la trama, combinado con la urdimbre, hace surgir la tela.

En el proceso está la creación como actividad sagrada para traer o formar algo nuevo en el mundo, algo que no existía antes. El producto, ya sea el maíz o la tela, contiene los símbolos mágicos que tienen las fuerzas divinas que se transmitirán a quien lo coma o lo use. El sentido queda entonces completo. Se ha vuelto al momento primero en que el símbolo era acción. La acción creadora de dioses y seres humanos para perpetuar el cosmos según se hizo en los primeros tiempos.

Dentro de las sociedades indígenas, el tejido no era únicamente una actividad que se debía aprender per se, sino que es una parte del desarrollo de la mujer; saber tejer no es sólo una habilidad, sino que forma parte del crecimiento personal en un todo con la comunidad y con la espiritualidad. Esta concepción de las actividades que se realizaban en las sociedades antiguas, difiere con mucho de los conceptos modernos que tenemos acerca de cómo actuamos en nuestro mundo actual.

Sólo el arte se acerca un poco a esa concepción que ya no manejamos comúnmente. En el artista se encuentran una comprensión y una sensibilidad que van más allá de 
la actividad práctica o de la cognoscitiva, es parte de su personalidad, de su ser mismo, de lo que podríamos llamar un espíritu especial. Todas las demás actividades sociales actuales, se ven como habilidades adquiridas del exterior y separadas de la personalidad individual.

En el mundo indígena mesoamericano, no era posible separar ambos aspectos y tanto la creación, como el producto y el sentido formaban un bloque inseparable con la existencia. El producto textil está conformado por las fuerzas que la mujer puso en movimiento, igual que cuando el dios creador movió las fuerzas del cosmos para crear el mundo.

Dentro del mundo están todas las cosas que sirven para agradar, imitar, simbolizar y dar satisfacción a los dioses, del mismo modo, el tejido contiene en su diseño, color y dibujo, los símbolos que permiten al ser humano mantener los lazos con lo divino. Esa organización simbólica es la parte medular que representa la creación, tanto de la tela, como del mundo.

En la modernidad surge un nuevo modelo social de la creación y de la invención que es el modelo científico tecnológico que aspira a sustituir la invención desde lo sagrado o desde lo artístico o por lo menos a equiparase con ello. Por medio de la ciencia el científico quiere dominar lo que creó el dios y plantear una alternativa a lo 
que creó el artista basándose en la verdad y su aplicación técnica.

Generalmente el objetivo del conocimiento científico es intentar hallar una explicación para los datos experimentales que posee, y a través de su indagación y aplicación, producir algo que no sabíamos, que no conocíamos, es decir, algo nuevo. Pero en las últimas décadas no solamente se busca el producir conocimiento en un sector aislado de la realidad, sino que se aspira a la obtención de un conjunto de leyes que expliquen el universo en su totalidad. La física ha entrado en una carrera sostenida por todos los que investigan en este campo, para develar una teoría totalizadora que nos explique el por qué de todas las cosas. $\mathrm{Y}$ no es una ambición ilusoria; se han hecho grandes avances al respecto desde los tiempos de Heinsenberg y Einstein.

La cuestión de la física comprende las fuerzas gigantes que se dan el en universo y las fuerzas que regulan el mundo de lo diminuto. Ahí está el universo, pero es necesario encontrar una nueva manera de verlo. Los frutos que se han cosechado en ese aspecto, muestran que la ciencia también pretende producir lo nuevo.

Cada vez que los científicos pretenden haber explicado algún fenómeno, la naturaleza surge con otra cuestión a resolver. Por esto, la ciencia no es algo acabado y absoluto en lo que podamos depositar tranquilamente 
nuestro deseo de explicación. Siempre habrá cuestiones sin resolver $y$, a pesar de su aparente solidez y la fama de incuestionabilidad que le damos al conocimiento científico, no es posible dotarlo con una credibilidad absoluta. Siempre habrá nuevas cosas surgiendo del mismo seno que pretendemos inmutable. También entre los científicos hay desacuerdos y teorías desechadas aunque su trabajo se base en "datos duros".

Al llegar a nuestro tiempo la ciencia pretende abarcar totalidades, desde galaxias cuya enorme dimensión hace algunos años ni podíamos imaginar, hasta las partículas más diminutas de que se haya tenido noticia, y es cuando sus teorías se pueden enlazar con las teorías cosmogónicas antiguas y sus productos se van a relacionar con los productos artísticos. La ciencia pretende resolver la teoría de la creación y quiere ofrecer productos como se hacía en el ritual, creando el avance tecnológico donde no solamente importa el desempeño sino también el diseño; con lo cual la ciencia al dirigirse a la creación, toca en el ámbito teórico al mito del origen y en el ámbito de la aplicación a los productos artísticos.

Estamos construyendo nuestro propio mito contemporáneo, construyendo teorías que giran alrededor de la sempiterna pregunta ¿de dónde venimos? y explicándolas con metáforas que sean accesibles al gran público que no comprende las complicadas formulaciones 
matemáticas. Los científicos, como los antiguos sacerdotes o chamanes, tienen que presentar los resultados de su visión de una manera comprensible, cercana al mundo donde se mueven los neófitos.

Por otra parte, las máquinas, productos de la ciencia, nos permiten traducir las observaciones a objetos tangibles, impresiones, cálculos, gráficas e imágenes de todo tipo que llevan a la concretización de los datos en abstracto. El científico no crea el mundo, pero sí crea modelos, teorías y máquinas que puedan acercarlo al conocimiento de lo que existe. Es un creador de nuevas realidades que explican el universo.

El científico se dirige a lo que existe, planteando nuevas formas de ver el mundo y develando verdades que antes no se conocían. El científico actual es el creador de los sentidos que consideramos más apegados a la verdad objetiva, aunque los descubrimientos de los físicos teóricos toman en consideración elementos que antes no hubieran sido considerados siquiera por las generaciones anteriores de científicos.

La ciencia elabora las novísimas formas de comprender el mundo, siempre desde la estructura social, pero buscando una explicación totalizadora y que funcione desde cualquier ángulo de abordaje. Busca la explicación de la creación y al plantear teorías acerca del inicio asume la postura del supremo sacerdote quien nos dice cómo 
empezó todo. Los científicos que se preguntan por el origen del universo son una minoría frente a la población del mundo, unos pocos iniciados que comprenden el conocimiento de una manera que a los demás les está vedada. La creación de formas que hagan comprensible dicho conocimiento, descansa en metáforas entendibles para los neófitos, que somos la gran mayoría.

Es una creación teórica sobre los productos naturales que nos muestra lo oculto del mundo en el que nos movemos. La sociedad determina lo que se estudia en las ciencias, pero cada vez más la física teórica está siguiendo sus propios caminos aunque depende del presupuesto que le den para la construcción de grandes máquinas que permitan comprobar lo que presuponen por medio de las fórmulas teóricas.

Con el avance de la historia, las sociedades cambiaron su percepción de lo que es el mundo. Poco a poco, cambia el sentido que se les da a las cosas, las reestructuraciones que se hacían en el campo social debían obedecer a las necesidades que iban surgiendo. Se abandonan mitos, se modifican otros, se enriquecen con nuevas observaciones, y el descubrimiento de instrumentos que ayuden a hacer más fácil y rápida cualquier labor, ocasiona que se modifique la visión de la acción divina. El surgimiento de las máquinas cambia el sentido del producto, y proporciona nuevos datos acerca de la 
naturaleza, por tanto se tiene que modificar la explicación del mundo.

El sentido se altera por la intervención de la tecnología, que ya no reproduce directamente lo que hace el dios, sino lo que hace una máquina. Ésta produce algo que ya no está involucrado como la repetición del cosmos sino como un producto autónomo.

En el tejido, por ejemplo, con la invención del telar mecánico, la diosa queda desplazada, los hombres se vuelven los principales responsables del tejido porque se está manejando una máquina que requiere la fuerza masculina, ya no involucra la postura de la diosa, se requieren habilidades mecánicas que no tienen un sentido relacionado con la creación de algo único, por el contrario, salen prendas por montones, todas iguales y $\sin$ el contenido que permita la asociación con lo divino.

El tejer se vuelve una actividad fría, sujeta a la explotación de los hombres. Ya no estarán realizando una actividad creativa, en la que ellos eran parte imprescindible del universo, sino una actividad mecánica que fácilmente puede sustituir al sujeto que la realiza. Ya incluso no se le llama tejedor, sino operario; su relación no es con los hilos y la forma que les dé, sino con la máquina a la que tiene que atender para que siga produciendo. La intervención de la ciencia y la tecnología no anula el textil, a pesar de que le quita su simbolismo propio de lo sagrado, sino que 
anula al tejedor. El producto sigue siendo un textil, pero con un carácter profano. La modernidad es la etapa de la profanación del ritual textil, porque elimina al tejedor como creador, ahora el tejedor es la máquina.

\subsection{La madre del mundo}

Sabemos que el elemento femenino en las primeras civilizaciones de Mesoamérica era tanto o más importante que el elemento masculino. Las sociedades rendían culto a lo femenino por estar asociadas con la fuente del alimento y de la vida. La mujer era el ser que podía dar vida a un ser como ella misma o a uno muy diferente, un varón; además podía ofrecer el alimento desde su propio cuerpo, dar la leche de sus senos.

La mujer representaba la esencia de la transformación: ella podía cambiar el grano en pan, la semilla en una planta, su cuerpo mismo cambiaba cuando iba a tener un hijo. Lo femenino era la energía transformada y transformable. El principio femenino del mundo representaba creación y vida, pero también tenía 
asociado siempre el elemento de destrucción, inherente a la transformación. Toda nueva creación implica que algo se destruye, lo anterior deja de ser para dar paso a lo nuevo.

Esta característica de lo femenino se puede observar en las diosas de la antigüedad. Pero es de notar que las diosas siempre tienen una relación más estrecha con lo humano, nunca se alejan demasiado de los seres humanos y mantienen ese lazo cercano con la tierra. La diosa crea cambios en el mundo pero también ella es ese mismo mundo. Además de ser objetos de culto, son figuras en las que se descubren las diversas formas del arquetipo femenino. ${ }^{19}$

La búsqueda de lo femenino se facilita con la figura de una diosa que ha tenido contacto sensible con el mundo y se identifica con todas las labores que realizan las mujeres. Por esto la ocupación, el papel femenino en la sociedad, es un papel sagrado, ligado profundamente con la creación y la fertilidad. La fertilidad fue objeto de culto desde el inicio de los tiempos. Las numerosas representaciones tempranas de diosas de la fertilidad que mostraban caderas y senos voluptuosos nos pueden dar una idea de lo importante que era el rendir tributo a la diosa madre, fuente de vida y alimento.

19 Downing, C. La diosa. p. 16. 
En las sociedades primitivas, el hombre cazador tenía menos tiempo para otras actividades, a diferencia de la mujer recolectora de frutos y observadora del desarrollo de las plantas en la naturaleza. Es hipótesis aceptada que la mujer descubrió que podía plantar semillas y así tener disponibles los frutos en zonas que pudieran ser más accesibles.

Históricamente, cuando surge el cultivo como una práctica sistemática, cambia el orden social; los hombres dedicarán algunos meses al año a preparar y sembrar la tierra, permaneciendo junto a su familia más tiempo del que pasaban antes. Esto permite desarrollar otras relaciones entre los integrantes de la comunidad y al interior de la familia misma. La mujer ocupa su tiempo en el lugar donde vive, aunque sigue con la recolección, pero a una distancia menor que la que tenía que recorrer antes, ayuda en las labores de la agricultura y atiende a los hijos. Con estos cambios que trajo el asentamiento, surgen otras actividades que ayudan a mejorar las condiciones y a facilitar la obtención del alimento. La cestería, el tejido de redes y la alfarería se desarrollan poco a poco.

$Y$ es en ese tiempo que se empiezan a elaborar los principios más estructurados de lo que podríamos llamar una religión. Es cuando se concibe el cosmos en que se concentran los dos principios, la pareja divina, el dualismo 
en todo lo que se manifiesta en la naturaleza. La agricultura se relaciona con la mujer porque se pone una semilla en ella y surge la vida, el alimento, e incluso los hombres que permitirán la subsistencia de las comunidades humanas. La tierra es equivalente a la matriz, de ella surge la vida.

Al depender la producción agrícola de las condiciones del clima, se pone más atención a los elementos; surgen las divinidades que representan el viento, la lluvia, la tierra y se establecen los cultos formales para dichas deidades. La mujer tiene una relación más cercana con las plantas, ha observado su crecimiento y ha descubierto sus propiedades, por tanto también tiene el don de la curación, por lo que se le ve como curandera y hechicera. Representa el vínculo con lo sagrado desde lo físico, no en abstracto, sino en la cercanía de la cotidianeidad.

Lo femenino también tenía que ver con la medición del tiempo. La luna marcaba mucho antes que el año solar más exactamente el transcurrir y, además tenía fases cambiantes más evidentes y que los humanos ligaban con el tiempo de gestación, de crecimiento de las plantas, etc. La luna representa la transformación.

Los cultos de la diosa estaban conectados con una noción del tiempo más cíclica, que caracteriza la conciencia mitológica, con una apreciación de 
los ritmos alternantes de crecimiento y mengua, plenitud y decadencia, despertar y dormir, actividad y receptividad, extroversión e introversión. ${ }^{20}$

El tiempo es un factor importante en la concepción antigua. Y la mujer es la parte humana en la que se puede ver más claramente los ciclos temporales; el embarazo, la menstruación, los cambios del crecimiento, y al estar a cargo de las labores de tejer -acto que como se verá está íntimamente ligado con la creación-, ocupa el sitio de creadora en el tiempo primordial y originario. Para las mujeres, la relación con las diosas es algo que se le da de forma normal, que le pertenece por naturaleza, mientras que el hombre, para acceder a lo divino como chamán o sacerdote, tiene que realizar acciones que lo distingan de los otros hombres y es un privilegio que se tiene que ganar.

El misterio que oculta la transformación se extiende al enigmático poder que tienen las mujeres en el mundo antiguo. Lo femenino siempre tiene algo que no se ve, que está oculto, el principio que rige la creación no se manifiesta claramente, sólo se puede ver alrededor, nunca se descifra claramente el proceso. Se siembra una semilla y lo que sigue está oculto a nuestros ojos, sólo

${ }^{20}$ Downing, C. La diosa, p. 28. 
podemos ver el resultado, ya cuando está formada la nueva vida.

La intuición que posee la mujer, también la hace poseedora del misterio de los sueños, de la adivinación del lenguaje para comunicarse con lo divino. La identificación de las mujeres con las diosas se da por medio de una búsqueda de las facultades y características de la diosa dentro de las mujeres mismas, y se proyecta hacia el exterior en los cultos y mitos. $Y$ aunque posteriormente el orden social se acomodó de manera patriarcal, las mujeres seguían poseyendo y practicando dichas facultades.

Los numerosos dioses nos presentan las múltiples relaciones que el ser humano establece con la naturaleza y lo inexplicable. La actividad que se le asigna a cada diosa, el ámbito en el que se mueve, su relación con lo masculino, nos da pistas sobre la actividad de la mujer en las sociedades en las que se estudia la divinidad femenina. La actividad humana depende de lo que sus dioses hagan en su mundo. Cada dios tiene su territorio de acción y el humano repite esa acción, parcial o totalmente para mantener el mundo en orden.

Por medio de estructuras simbólicas, el ser humano construyó la explicación del mundo. Los mitos explican el origen de los más importantes acontecimientos de la humanidad. En su momento, cuando estaba vigente, el 
mito no hablaba de ficción, sino que se considera "revelador de la verdad por excelencia." ${ }^{21}$ En cada cultura, los mitos se han desarrollado como una manera de estructurar y explicar el mundo en el que se vive.

El mito es muy poderoso porque muestra imágenes cercanas al ser humano, y le sugiere cómo resolver o actuar frente a situaciones dadas. El vivir el mito hace que se profundice en la vida individual. Aumenta el conocimiento interior y explica el porqué de las acciones que se llevaban a cabo en la cotidianeidad.

El repetir el mito le da sentido a la vida. Se tiene entonces un hilo conductor para atravesar el mundo, para poder establecer relaciones con otros seres humanos, para entenderse como individuo perteneciente a una comunidad dada.

Por su actividad en el hogar y como proveedoras de comida y vestido, por su papel de dadoras de vida las mujeres son continuadoras del arquetipo primordial; la diosa madre, dadora de vida, pero también de destrucción.

Esta dualidad -que es muy evidente en las diosas aztecas - completa el arquetipo femenino y el estudio de sus detalles nos puede dar un mayor entendimiento de cómo los mitos se forman a través de imágenes de la diosa en relación con lo que forma parte de su mundo, del

${ }^{21}$ Eliade, Mircea. La búsqueda, p. 23. 
lugar al que pertenece y desde donde instruye a los humanos. La construcción de los templos en los que se adorará a la diosa, el ritual que hay que seguir para complacerla, los utensilios que están relacionados con su actividad en el mundo, la relación con los dioses masculinos, las partes de la naturaleza de los que se apropia, el carácter de cada una de las diosas, la complejidad de sus atributos, nos dan una idea de la importancia que el culto a las diosas tenía en las culturas antiguas.

Y lo anterior no ocurre como algo aislado, sino como un todo en el funcionar del ámbito celeste y por tanto en el mundo de los humanos. La deidad suprema era doble y contenía en sí a la pareja creadora, a los principales dioses del panteón mexica que eran Ometéotl "señor dual" contraparte masculina de la deidad suprema y Omecíchuatl "señora dual" contraparte femenina de la deidad suprema. ${ }^{22}$

La diosa madre representa el origen de la vida en el mundo, la vida puesta en cuerpos que funcionen en la materialidad. Es también la tierra a la que todo vuelve y la que siempre está dispuesta a recibirnos. La transformación es su característica esencial. Ella lo contiene todo, incluso, en su caso, contiene al hombre

22 Arqueología mexicana. “La Religión mexica”, p. 26. 
mismo durante nueve meses; en ese tiempo se alimenta y vive por los dos géneros.

El culto a la diosa madre persiste incluso en las religiones que han decidido hacerla a un lado. El lado femenino se muestra como necesario porque el dios masculino no posee las otras características que hombres y mujeres necesitan para sentirse completos. Incluso en las religiones patriarcales siempre hay una mujer que es el vehículo para que los humanos continúen poblando la tierra y tengan el vínculo con lo divino.

Como ya se dijo, la mujer se identifica con los conceptos de creación, de dadora de vida, de ciertas características que le pertenecen tales como la intuición, las emociones a flor de piel, el dolor para dar la nueva vida, la transformación y el cambio. Lo femenino contiene la delicadeza, la belleza, pero al mismo tiempo puede contener la destrucción y la maldad velada.

Las mujeres forman parte importante de las repeticiones de los mitos en las sociedades prehispánicas. La dualidad que se presenta en los mitos y creencias cosmogónicas de muchas culturas en el mundo, se halla también en las culturas mesoamericanas.

Se hace una división entre los opuestos, por ejemplo entre las figuras ya mencionadas del Gran Padre (principio masculino) y la Gran Madre (principio femenino) y al mismo tiempo ambos forman parte del dios originario 
y primordial, y esa manera de concebir el universo se extiende a todas las áreas de la vida de dichas culturas; a todo se le encuentran las características que permiten su ubicación en uno u otro de los lados.

En términos mesoamericanos, lo femenino tiene que ver con la oscuridad, con la tierra, con la humedad y la sexualidad, mientras que lo masculino se relacionaba con la luz, la vida, la sequedad, etc. ${ }^{23}$

Sin embargo, es necesario hacer notar que no tenían el aspecto de bien o mal como lo podríamos percibir en esta época, más bien eran identidades inseparables y de cuyo seno podían provenir tanto cosas para el bien de los hombres como para su mal.

${ }^{23}$ Revista de Arqueología mexicana. La mujer en el mundo prehispánico, p. 10. 


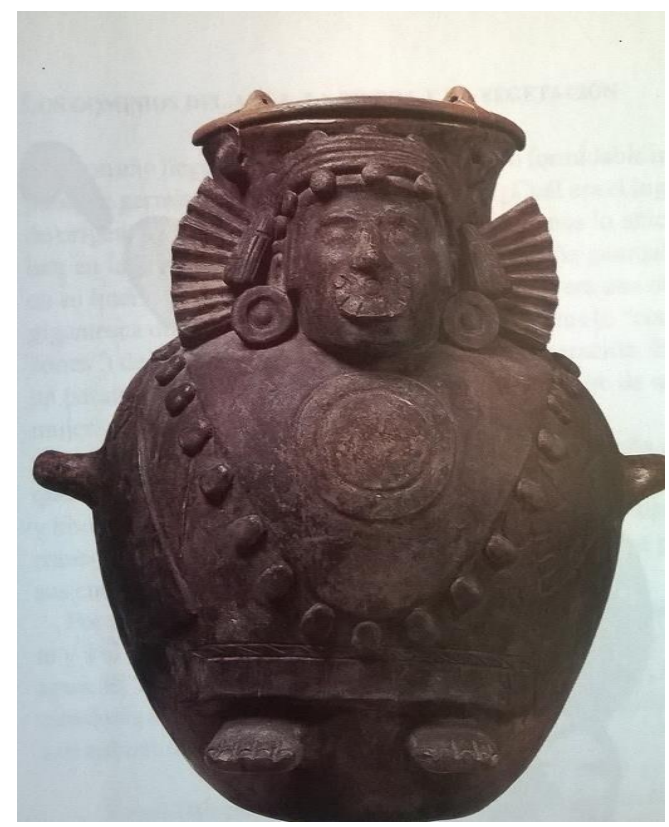

Deidad de la parte femenina del cosmos. Diosa de las aguas. ${ }^{24}$

En cuanto al tejido, la diosa que enseña a tejer, tiene cualidades femeninas como la paciencia pero también el ingenio, la laboriosidad, la creatividad, el entendimiento, la disciplina y la imaginación para crear nuevos tejidos. Esta relación del tejido con la inteligencia se evidencia en el hecho de que las mejores tejedoras eran destinadas al servicio del templo, debido a su perfección en el dominio del tejido.

El tejer puede contener un alto grado de complejidad en la conversión de algún dibujo a los hilos o el dar forma

24 Idem., p. 9. 
circular a una tela. Esto se puede ver en los tejidos que se han encontrado en Perú, por ejemplo.

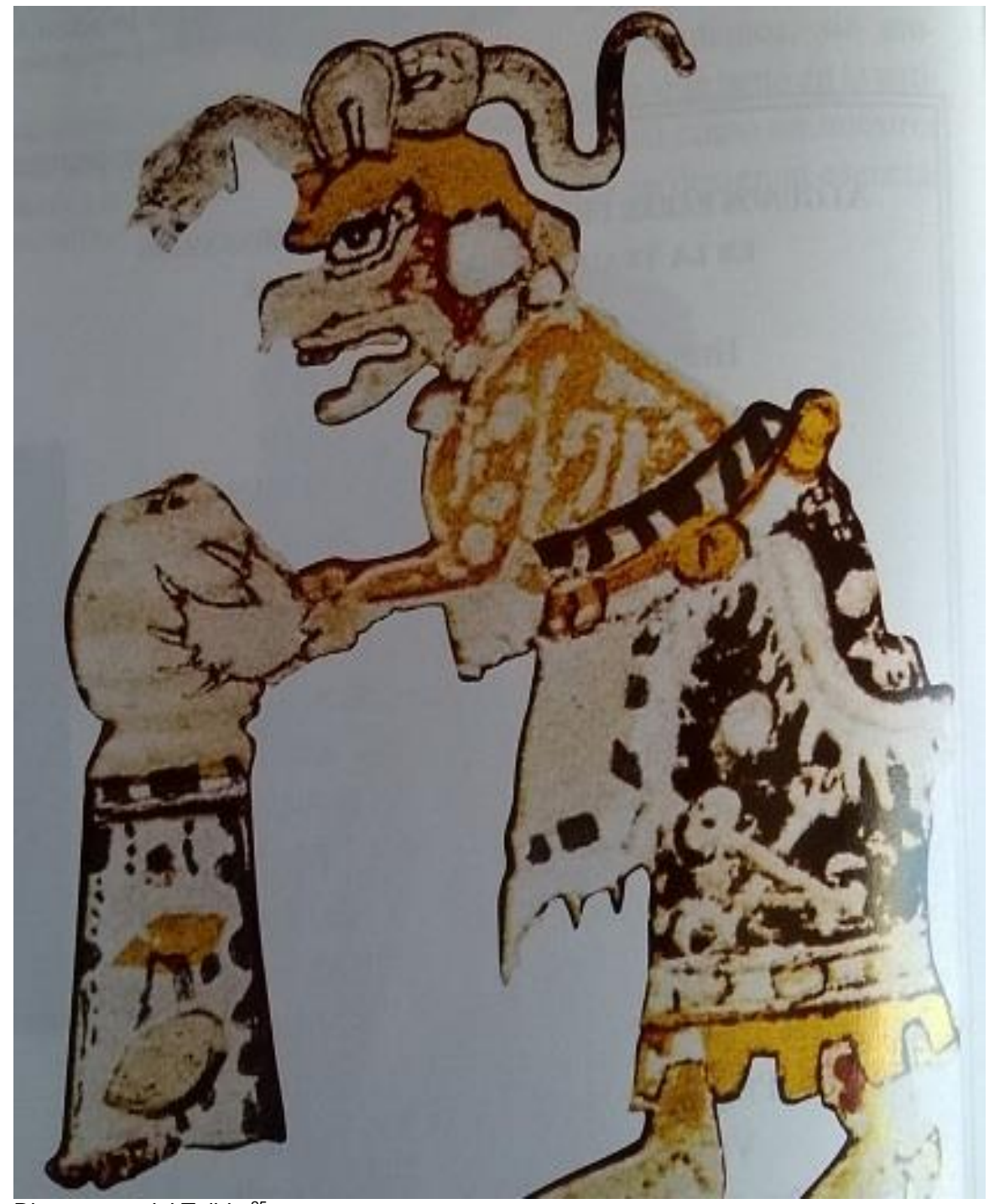

Diosa maya del Tejido. ${ }^{25}$

${ }^{25}$ Arqueología Mexicana. “La mujer en el mundo prehispánico”, p. 10. 
En la América prehispánica, el telar por excelencia era el telar de cintura, aunque existieron también de estacas y verticales. Aunque en apariencia muy rudimentario, el telar de cintura era una herramienta con la que se trabajaban técnicas muy complicadas y elaboradas, pues en la actualidad se han analizado los tejidos encontrados y se ha visto que incluso se podía tejer una tela con orillas curvas o redondeadas, además de diseños intrincados que requieren una enorme destreza en el manejo de dicho telar.

En la figura que sigue se ilustra la conformación del telar de cintura utilizado por las mujeres indígenas de México y el cual no ha cambiado mucho al paso de los siglos, pues podemos ver ilustraciones de estos telares en los códices prehispánicos.

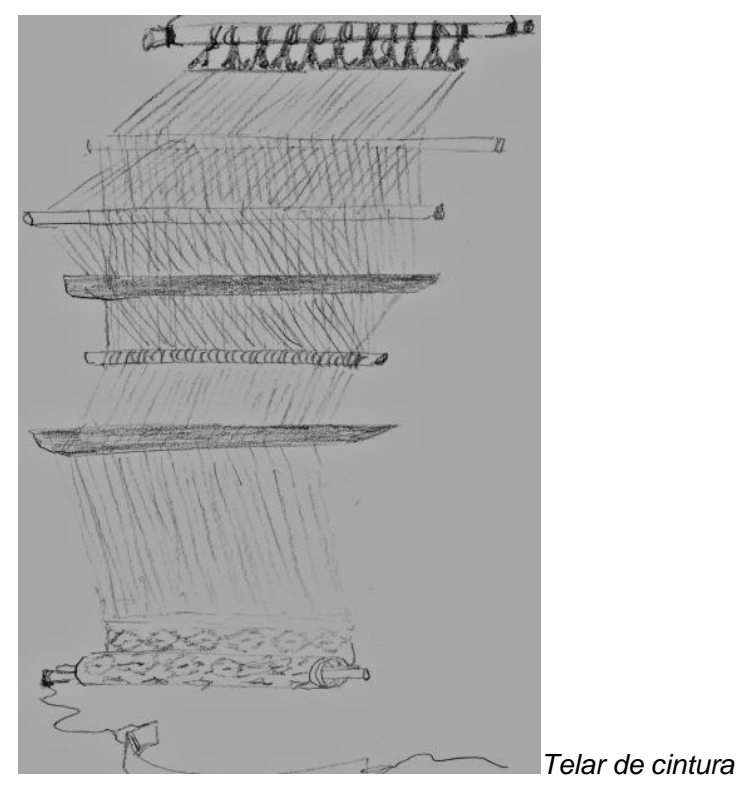


Como se puede ver, la estructura es sencilla, una serie de varas separan el hilo y se podían lograr tejidos complicados. En este telar se tejían las prendas de toda la sociedad y los motivos que se plasmaban en ellas, formaban parte de algo que iba más allá de la decoración, tenía que ver con el simbolismo mágico y lo dado a los seres humanos por los dioses, con la concepción del origen y preservación del universo.

La significación del acto de tejer rebasaba la cuestión práctica, es un momento en el que el tiempo cobra vital importancia porque se accedía a una realidad que superaba la realidad cotidiana.

En el acto de tejer se recreaba el surgimiento de mundos nuevos, la creación misma. El cuerpo femenino es parte del telar. No es algo separado, sino que funcionan simultáneamente. El movimiento, el equilibrio, la parte con la que se conecta, circulando con una cinta el vientre desde donde sale el tejido, representa la relación física del tejido con la fertilidad.

La postura exigida en el telar de cintura para tejer, representa una habilidad que hay que adquirir, es realmente una técnica corporal en la que tiene que haber sincronización y soporte de una postura arrodillada 0 sentada en el suelo con las piernas estiradas, durante todo el tiempo que se dedica al tejido. 


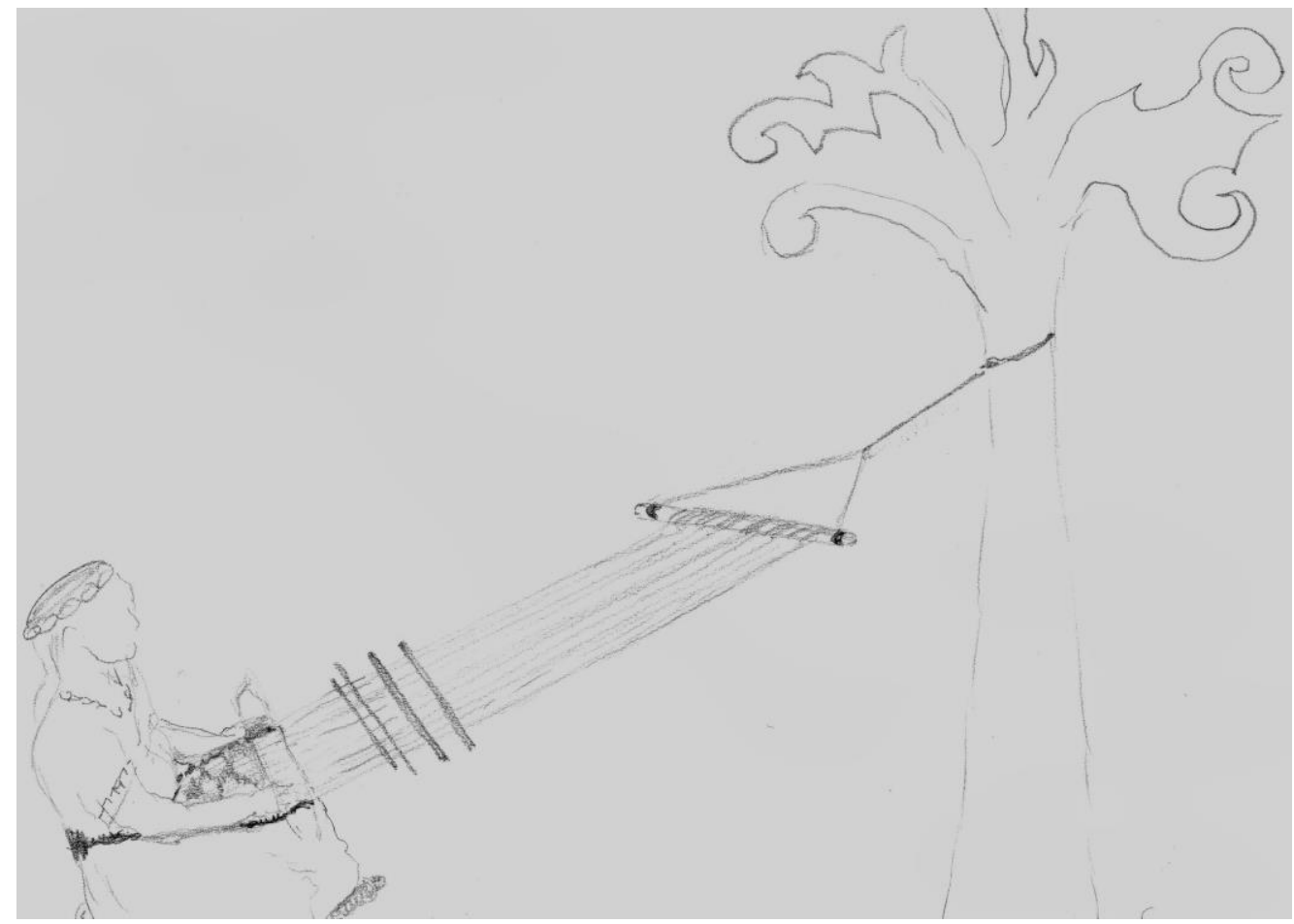

Mujer tejiendo en telar de cintura amarrado al "árbol-centro del mundo".

Conservar la tensión en el telar de cintura requiere echar para atrás la espalda, y moverse hacia adelante cuando se quiere abrir la urdimbre, levantar el peine y rotar el espaciador, son acciones simultáneas que requieren de una coordinación compleja que se enseña desde que las niñas son muy pequeñas para que puedan acomodar su anatomía al proceso. Todos los atributos que se necesitan 
para que esta actividad se lleve a cabo fueron enseñados por la diosa y puestos en el cuerpo de la mujer que teje.

En Sudamérica existen todavía en la actualidad grupos indígenas que en sus rituales repiten los movimientos que se realizan al tejer, como parte de una danza al celebrar las adoraciones a los dioses. Porque ese movimiento es un movimiento mágico, que da lugar a un nuevo mundo que antes no existía, la tela que surge a partir de la repetición de esos movimientos, es la analogía del surgimiento del mundo desde las manos de los dioses.

El tejido tenía doble importancia; era concebido como actividad sagrada, con contenidos míticos y también como actividad económica primordial, ${ }^{26}$ pues todos vestían con esas telas y además éstas servían para pagar tributos 0 para intercambiar por otros artículos.

La relación mujer-tejido era para las culturas mesoamericanas base del oficio que permitía obtener prendas, pero también base de la feminidad como principio que da vida desde el origen de los tiempos.

\footnotetext{
"El origen ha de ser femenino. Al menos lo es en el pensamiento mesoamericano, que remonta el principio de todas las cosas a un ser de naturaleza fría y húmeda."27
}

\footnotetext{
26 López Austin, A. Los dioses..., p. 51.

27 López Austin, A. Los dioses..., p. 51.
} 
Esto afirma López Austin, pues los elementos del ser del principio de los tiempos corresponden a la naturaleza de lo femenino.

Nos narra mitos nahuas que hablan de esa diosa primigenia, Cipactli, que era un monstruo hasta que dos dioses que trajeron la fuerza masculina, la dividieron creando el cielo con una parte y la tierra con toda su riqueza natural con la otra. La existencia de muchos dioses no se contradice con la existencia del dios único creador de todo, porque éste también tiene una naturaleza dual.

Como ya se mencionó, en las concepciones maya y azteca algunos de los dioses son mezclas de la esencia femenina y masculina. En la divinidad primera y mayor, se funden las características opuestas y complementarias, luego se puede ver que se divide en el dios masculino primordial y la gran madre, dadora de vida.

De la existencia de los opuestos dependía el funcionamiento del mundo, pues la acción era recíproca, uno hacía que el otro existiera y funcionara. Las dos fuerzas se movían para hacer que el mundo tuviera muerte y vida.

La mitad de las fuerzas del cosmos tenía carácter femenino, y el cosmos era habitado tanto por dioses como 
por diosas. Son los poderes y la naturaleza de su acción los que los situaban en la parte femenina del cosmos. ${ }^{28}$

En las sociedades maya y náhuatl, el papel de la mujer era muy importante.

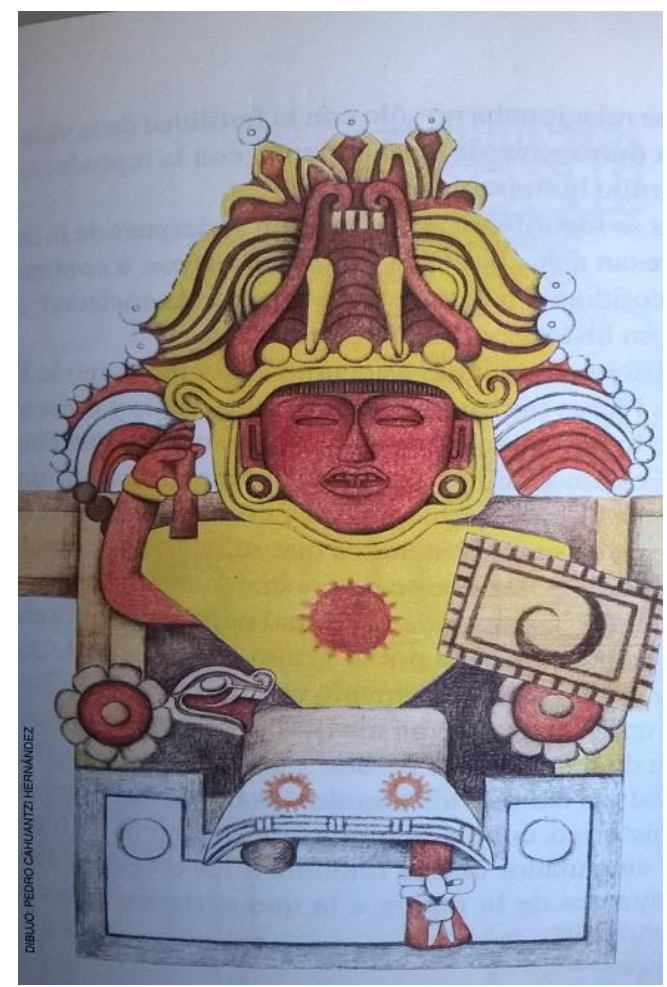

Mujer guerrera o gobernante..$^{29}$

Generalmente las referencias de dichas culturas se toman en abstracto, y no nos detenemos a pensar cuál era el papel de los elementos femeninos en esos grupos. Cuando de dinastías se hablaba, el lado femenino era tan importante como el masculino y el vínculo con las diosas

${ }^{28}$ Arqueología mexicana. "La mujer en el mundo Prehispánico. p. 13.

${ }^{29}$ Arqueología Mexicana “La mujer en el mundo prehispánico”. p. 25. 
daba la importancia debida para ir a los orígenes de las familias reales o nobles.

Sobre todo en la cultura maya, los jeroglíficos y los murales muestran a estas mujeres participantes de la vida política, e incluso que fungieron como gobernantes de su pueblo, como por ejemplo lo descubierto en Palenque, de cuyos gobernantes doce fueron mujeres. ${ }^{30}$

Los dioses no son entes lejanos y ajenos al habitante mesoamericano, la madre del mundo habita en cada mujer, y cada mujer cumple con su misión de continuar la vida en el mundo, de dar servicio a los dioses poniendo sus habilidades en las acciones que le son propias, en esos mundo arcaicos la parte femenina ocupa la mitad del mundo creado y acomoda el mundo terrenal para que imite al mundo celeste.

Todo este simbolismo se guardó en los tejidos y algunas figuras persisten hasta nuestros días, aunque se haya perdido algo de su significación sobre todo desde tiempos de la conquista, pues al cambiar la estructura social y religiosa, se han ido perdiendo también poco a poco los contenidos cosmológicos de las figuras tejidas.

Es probable que cuando los frailes buscaron registrar cuidadosamente los procesos pertenecientes a la cultura encontrada, escribieran las técnicas de hilado, tejido y teñido de los hilos, pero se ha comprobado que los

30 lbid., p. 36. 
indígenas se guardaron para sí muchas de las técnicas que utilizaban y daban a veces indicaciones incompletas. Antes de la conquista, las mujeres habían sido las depositarias del proceso entero que lleva a la elaboración de telas, por lo que es probable que ellas guardaran muchos secretos, pues con la llegada de los españoles, la mujer fue relegada a un nivel inferior, sumiso y abnegado y fueron los hombres los que se incorporaron a la nueva industria española del textil.

Los telares de cintura siguieron funcionando, pero en la intimidad de los hogares y ajenos al proceso mecanizado que se instaló en toda la Nueva España para satisfacer la demanda de telas al estilo europeo. Las mujeres continuaron fieles a su tradición textil, aunque de a poco se fue diluyendo el sentido de la cosmología anterior y solo se conservaron las formas. ${ }^{31}$

Es necesario hacer notar que dentro de algunas sociedades arcaicas, en cierto momento, cuando los niños crecían, la relación con la madre significaba la relación con el mundo profano, y la relación con la línea masculina era la relación con el mundo sagrado, por esto las iniciaciones se hacían para dar el conocimiento que se necesitaba para convivir con los hombres.

31 Pohl, Mary y Feldman H, Lawrence. "The Traditional Role of Women and Animals in Lowland Maya Economy”. pp. 296-311. 
De igual forma, los ritos de iniciación de las muchachas, tenían que ver con el tejido, y la hilatura se consideraba una actividad mágica y poderosa. ${ }^{32}$ El simbolismo de estas artes es muy significativo, pues la diosa hila el mundo y teje la trama de las vidas en la tierra.

La actividad del tejido, con todos sus procesos, da a las mujeres un poder especial y una apreciación por parte de los hombres e incluso las hace receptoras del favor de los dioses dependiendo de su habilidad para realizar las labores. Muchas de ellas eran destinadas al templo gracias a sus habilidades en el tejido.

En la pubertad, las mujeres conocen el significado y la relación que guarda su actividad de tejeduría con la madurez sexual y por lo tanto la reproducción y su ascenso al equivalente de la diosa madre, la diosa creadora y dadora de vida.

${ }^{32}$ Eliade, Mircea. Nacimiento y Renacimiento, p. 76. 


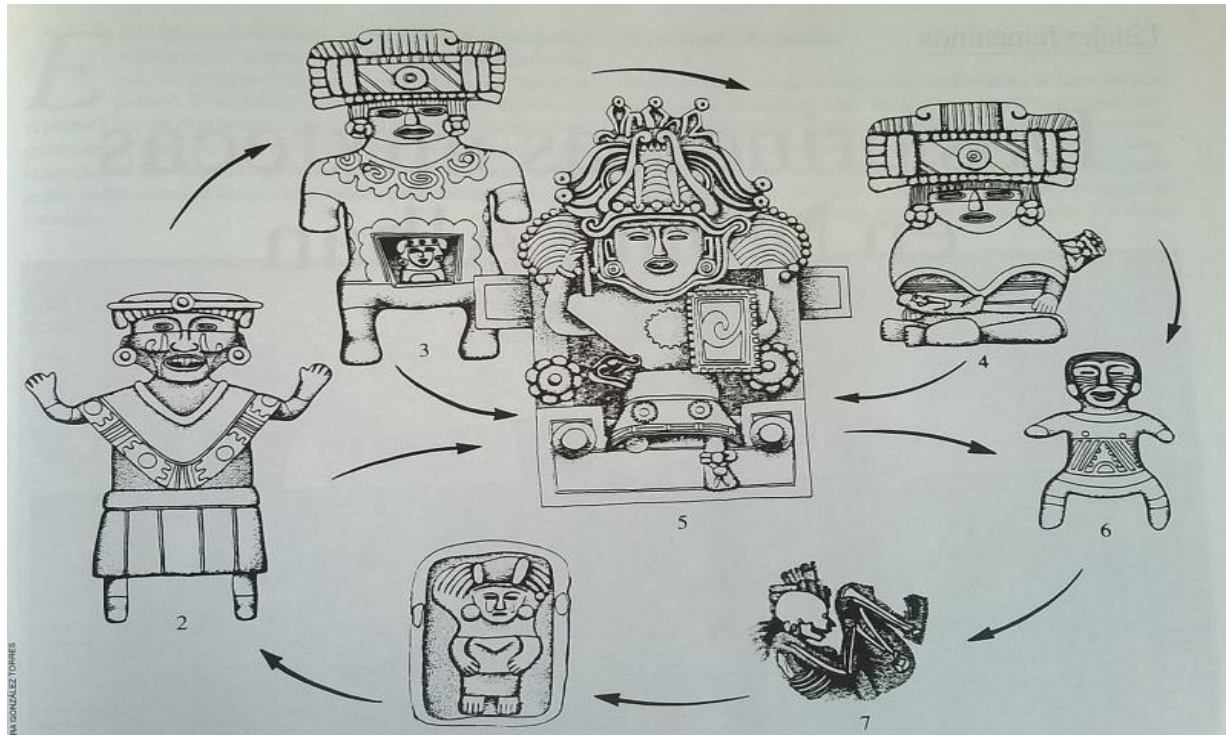

Mujeres de Xochitécatl

En la imagen superior "se representan las distintas edades y posiciones sociales de las mujeres, desde el nacimiento hasta la muerte. Representa también a las doncellas oradoras, las mujeres embarazadas, las madres, las gobernantes y las ancianas". 33

Las cuevas o grutas que se representan en la mitología mesoamericana, también representan el regreso a la madre tierra, o el surgimiento desde su seno. La madre ve a sus hijos salir y los recibe cuando mueren, aunque también puede darse el caso, en situaciones especiales, de que entren de nuevo a su seno y salgan de ahí

${ }^{33}$ Arqueología Mexicana. La mujeres en el mundo Prehispánico, p. 27. 
renovados o con secretos que les han dado los dioses. La tierra da y recibe. Podemos ver una representación de ello en la siguiente imagen. ${ }^{34}$

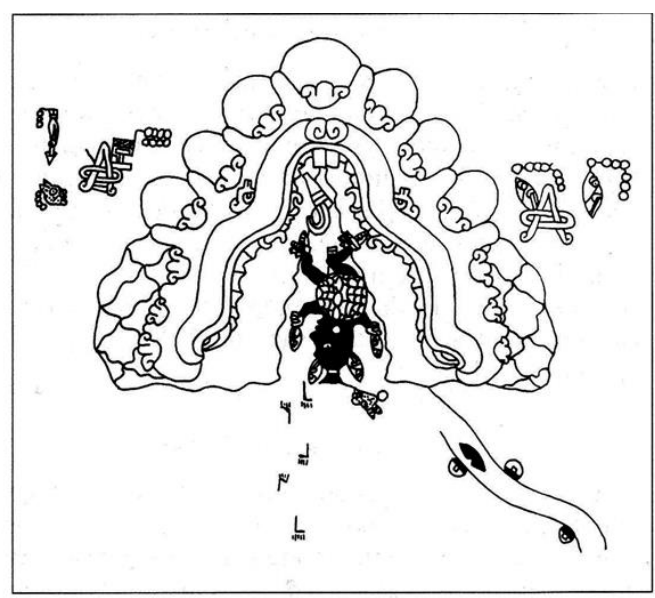

Figura 5. Escena mitológica en un documento pictográfico mixteco. Uno-Tigre desciende de cabeza dentro del Lugar de las Siete Cuevas. Códice Selden I o Rollo Selden, lám. Iv.

La gran madre es la proveedora pero también la que transforma la muerte en nueva vida, y la que convierte los lazos entre la vida y la muerte en un ciclo creativo. La parte femenina está ligada indisolublemente con la tierra. Tal es el caso siguiente que puede servir como ejemplo: Chicomóztoc, la montaña que da a luz por medio de siete úteros y que en cada parto hacía nacer a siete grupos

${ }^{34}$ Imagen tomada de Historia Antigua de México, p. 249. 
humanos, ${ }^{35}$ dando así origen a los distintos grupos que poblaron Mesoamérica.

Varios mitos tratan la naturaleza salvaje de la mujer, destacando su carácter primordial, cuando todo era húmedo y caótico.

De esta manera, la mujer contiene dentro de sí la pureza, la suavidad, pero al enfrentarse con el hombre puede ser dura y empecinada, por lo que en algunos mitos la preñez tiene que darse de forma casi mágica, para que dé a luz a un ser poderoso.

Así de grande es el simbolismo de la tierra-madre para las sociedades de las que tratamos.

${ }^{35}$ López Austin, A. Dioses del norte... p. 137. 


\section{4.- El mito del origen en dos antiguas culturas mexicanas}

\section{Las antiguas religiones prehispánicas}

Lejos está de nuestra intención hacer un análisis exhaustivo de las complejas religiones prehispánicas que aún siguen bajo la lente de los eruditos, el sólo plantearlas excedería los límites de este documento, por lo que únicamente se tomarán ciertos elementos que los estudiosos han encontrado y que nos servirán para los propósitos de este trabajo.

Se hará el intento de avanzar coherentemente en las concepciones mesoamericana y maya para mostrar la postura de ambas culturas respecto a los mitos relacionados con el origen.

Las religiones siempre tienen un mito del origen. Diferentes imaginaciones, historias, contenidos, rituales, imágenes y contexto, forman la mitología de las agrupaciones humanas.

Es un mundo lleno de riqueza expresiva que nos dice mucho del ser humano a lo largo del tiempo. Los mitos del origen tienen especial importancia porque proporcionan 
una respuesta a la pregunta siempre formulada acerca de dónde venimos.

En los mitos antiguos se observaban los fenómenos naturales y se creaban entidades para explicarlos; otras veces, a ciertos humanos que sobresalían de los demás se les daba el ascenso a la categoría de dioses; los animales formaban parte de la imagen del dios al destacar alguna cualidad que poseían y se integraba a su representación y a sus atributos.

Una vez reunidas las historias de los dioses, se formalizan y se les añaden rituales, se institucionalizan y se procura que las creencias sean diseminadas entra la gente formando una religión. Pero las religiones dejan de ser vigentes por alguna razón y entonces se convierten en un puñado de mitos que pueden seguir existiendo durante mucho más tiempo que la religión de la que formaban parte.

Un ejemplo de esto es la mitología griega y muchas otras mitologías antiguas que conocemos, y cuya religión ha desaparecido. Un poco pasa con las religiones prehispánicas cuya vigencia ha caducado pero se siguen manteniendo los mitos; por ejemplo, la figura de Quetzalcóatl tiene una presencia actual entre muchos mexicanos. Los mitos siguen en la psique de la contemporaneidad y han logrado sobrevivir al tiempo. 
Es importante señalar, antes de entrar a una muy somera descripción de las ricas y complejísimas religiones prehispánicas que nos interesan, algunas consideraciones que hay que tener en cuenta: como cualquier religión, las creencias de los antiguos mexicanos no eran un proceso acabado, definido, más bien eran un proceso en construcción y continuo cambio; asimismo no conforman un suceso espontáneo e inmediato, es un producto que vino enriqueciéndose a lo largo de miles de años.

Alfredo López Austin expresa a propósito de la religión, la cosmovisión y la magia de Mesoamérica. Esa gran área cultural de la que nos dice "mantuvo una unidad histórica, milenaria, homogénea en la profundidad de sus procesos y muy diversa en sus expresiones culturales." ${ }^{36}$

La cosmovisión de los pueblos antiguos es, como cualquiera, construida por todos, cada segmento que posee un individuo se articula con los segmentos que tienen los demás y forma un todo que no está articulado por completo, pero permite un dialogo y una convivencia en la misma dirección; y aunque haya discrepancias, hay también coincidencias que permiten el avance.

Otro punto a considerar es que los hallazgos más recientes han permitido saber que ambas civilizaciones,

${ }^{36}$ Arqueología Mexicana, Mitos de la Creación, p. 21. 
nahua y maya, no son entes separados totalmente, sino que tienen un crecimiento en común y las relaciones establecidas entre ellas fueron más cercanas de lo que se pensaba anteriormente.

Existieron muchos y variados pueblos que no eran parte de esas dos culturas, los estudios que se han hecho encuentran entre ellos diferencias, pero también similitudes profundas entre las creencias de los habitantes del ahora llamado territorio mexicano. Esto permite a los estudiosos construir visiones generales del pensamiento mítico mesoamericano que sobrepasan a las particularidades encontradas en cada uno de los centros de dichas culturas.

\begin{abstract}
"Las variedades religiosas regionales y temporales se dieron en torno a un núcleo firme de concepciones y ritos que permite hablar de la unidad religiosa mesoamericana como producto de un mismo devenir histórico y como posibilidad de comunicación entre los distintos pueblos mesoamericanos a través de un código religioso común. El núcleo no fue inalterable; pero sí muy resistente a la trasformación."37
\end{abstract}

También se han encontrado las similitudes y las diferencias del pensamiento religioso y se está haciendo

37 Idem. p. 241. 
el intento de tejer el hilo conductor que nos permita comprender el proceso como una totalidad.

Los expertos no han encontrado signos de que el orden religioso mesoamericano estuviera dividido en lo que ahora pudiéramos llamar distintos credos, más bien consideraban que las diferencias en rituales y dioses formaban parte de una misma unidad total, por lo que era fácil la comunicación en el aspecto religioso entre los distintos pueblos.

En los vestigios arqueológicos de los primeros pueblos sedentarios, sobre todo en las figurillas de cerámica de los antiguos agricultores, se encuentra una asombrosa semejanza que puede responder a la existencia de muy viejas creencias similares. ${ }^{38}$

Para este trabajo sólo se dará una introducción a las principales líneas de las religiones maya y náhuatl, sin pretender cuestionar, ni mucho menos esclarecer las lagunas que pudiera haber, sino, como ya mencionamos, únicamente para tomar elementos de lo aceptado por expertos para sostener nuestro avance en el tema.

Es bueno también dejar claro que a pesar de que pertenecían a la misma cultura mesoamericana, existían distintas particularidades entre la religión que practicaban

${ }^{38}$ López Austin en Aspectos fundamentales... p. 237. 
los pobladores de México-Tenochtitlan y los de otros lugares cercanos, así como entre los mayas de las diferentes regiones, y también entre los que pertenecían a la élite y los del pueblo, pero una vez tenido en cuenta lo dicho anteriormente, eso no obsta para los propósitos que se buscan en este análisis, pues se tomará únicamente lo

que ayude a definir y formar la estructura general y aceptada de ambas religiones en cuanto al mito del origen.

\section{El mundo náhuatl}

Usualmente cuando se menciona al pueblo azteca se piensa en un pueblo guerrero y sanguinario, pues es el aspecto violento el que sale más fácil a la vista en la sociedad actual, pero no se tiene presente el significado de dichos sucesos.

Es imposible comprender dichas culturas si no se tiene a la vista todo el sentido del mundo que tenían dichas sociedades. Además, en todas las sociedades ha habido y habrá sucesos violentos que lleven a la muerte de muchos de sus miembros.

Es necesario avanzar en la comprensión de la existencia del mundo como un todo y la importancia de la acción del individuo en el mantenimiento de todo lo que existe. El 
sacrificio era una parte necesaria para que el mundo continuara, pero concentrémonos en la explicación del mundo.

Todo lo que existe tenía diferentes tipos de materia, combinadas de tal manera que daban origen a la individualidad de los seres. Había dos tipos de materia: la ligera y la densa, ${ }^{39}$ además cada una de ellas tenía diferentes elementos que combinados, construían los distintos aspectos de los dioses, objetos, elementos naturales, tipos de individuos, etc.

Entre dioses y humanos había una familiaridad que determinaba los actos de los humanos bajo la influencia del carácter de los distintos dioses. Nos dice López Austin que el tiempo de los dioses no transcurría de igual manera que el tiempo de los humanos, y esto daba a los seres divinos la posibilidad de estar en varios sitios al mismo tiempo y de llevar a cabo diversos actos en el mismo minuto y convertirse en seres mundanos.

El tiempo surgía de los troncos de los árboles que sostenían el mundo en las cuatro esquinas y salían como fuerzas diferentes siempre en rotación y activando el mundo para producir la historia.

La cultura mesoamericana basaba sus fundamentos en las diversas relaciones establecidas entre lo mundano y lo

39 López Austin, Alfredo. Op. cit. p. 242. 
divino. No había esa brecha entre los productos humanos y los productos divinos porque todos eran uno y lo mismo. El concepto de "flor y canto" encierra una profunda reflexión sobre el origen, la permanencia y término del mundo y de la vida; por medio del acercamiento a la poesía y al arte se determina el contenido profundo de todo el simbolismo náhuatl. La concepción de la humanidad, del mundo y de los dioses se expresa en los poemas que elaboraban los sabios mexicanos.

Las preguntas acerca del origen de la vida que se han hecho los sujetos en todas las culturas fueron planteadas también en esta sociedad antigua y las respuestas se encuentran presentes en la educación y la manifestación artística y religiosa. La búsqueda de la verdad y la explicación de todas las cosas se encontraban siempre con el cambio y la muerte, y el ser humano tenía que situar su pensamiento ante esas realidades.

Nos dice León Portilla, que

...el concepto náhuatl de verdad (neltiliztli), con la connotación de "raíz y fundamento", dejó ya entrever implícitamente el sentido que dieron a su búsqueda. No les preocupaba tanto obtener una representación fiel de lo que existe cuanto encontrar una raíz y fundamento para su propia existencia que inevitablemente tiende a desvanecerse como un sueño y a desgarrarse 
como las plumas de quetzal. Persuadidos los sabios indígenas, después de analizar hondamente el problema, de la dificultad, si no es que imposibilidad, de llegar a conocer sobre la tierra algo tal como es en realidad, repiten en sus textos sentencias como éstas: "puede que nadie diga la verdad en la tierra...”; “¿cuántos dicen si hay o no verdad allí, en la región de los muertos...?"; "tal vez sí, tal vez no, como dicen..." Por eso -conviene insistir en ello- su búsqueda de la verdad diferirá por completo de cualquier concepción de tipo griego u occidental en la que exista el propósito de inquirir por la esencia de las cosas. Al hombre náhuatl le interesa no "la contemplación de las esencias", sino la posesión interior de una raíz para dar apoyo a su rostro y corazón inquieto. ${ }^{40}$

La religión mesoamericana no era un cuerpo aparte de la vida cotidiana, estaba articulada en todos los aspectos de la actividad social e individual. Era una religión estrechamente ligada a la cuestión agrícola y sobre todo a la lluvia y al devenir del tiempo. ${ }^{41}$ Como dijimos, todo estaba hecho de dos tipos de sustancias, una pesada y otra ligera. Lo que existe en el mundo y los mismos humanos estaban conformados por los dos tipos de

\footnotetext{
40 León-Portilla, Miguel. Los antiguos mexicanos. p. 177.

41 López Austin, Alfredo. "La religión, la magia y la cosmovisión". En Historia Antigua de México, p. 242.
} 
sustancia pero los dioses sólo estaban hechos de la materia ligera.

Para los nahuas, el origen de todo comenzaba con la

(...) pareja de dioses primordiales increados, llamada Ometéotl, "Dios dual", la cual estaba formada por Tonacateuctli y Tonacacíhuatl. De esta pareja, que moraba en el cielo decimotercero y más alto (Omeyocan, "Lugar de la dualidad"), procedieron por generación cuatro dioses principales y creadores, a todo los cuales se podría tal vez llamar genéricamente "Texcatlipocas"; los nombres de éstos era: Mixcóatl o Tlatlauhqui Texcatlipoca ("Tezcatlipoca rojo"), Yayahuque Tezcatlipoca ("Tezcatlipoca negro") o Tezcatlipoca a secas, Quetzalcóatl (¿Tezcatlipoca blanco?) y Huitzilopochtli (¿Tezcatlipoca azulverde?)." ${ }^{42}$

Éstos eran los dioses primordiales, pero había muchos dioses secundarios y semidioses que eran venerados por sus diferentes facultades. Según las características del dios y el campo de lo humano sobre el que tenía influencia se construía el culto a su alrededor. Los códices y los frescos nos muestran a un mismo dios representado de maneras diferentes, pero siempre mostrando algún atributo que le es propio, lo que lo identifica.

42 Tena, Rafael. “La Religión mexica”, p.11. 
La existencia de la pareja primordial nos muestra que el lado femenino del cosmos existió desde el principio de los tiempos divinos. Formaba parte de la divinidad primera, increada y eterna. Se relacionaba directamente como la proveedora de alimento, lo más importante porque sostiene la vida.

También se menciona a Teteoínnan, Madre de los dioses que es la representación del arquetipo de la gran madre, de donde sale todo y desde donde todo se origina.

El origen del mundo en la cosmogonía mexica se puede resumir así:-

La eternidad original, el tiempo primordial y el tiempo actual se enlazan en una continuidad, que es simultáneamente lineal (porque los hechos no se repiten) y cíclica (porque los acontecimientos se ajustan, sin embargo, a un "patrón recurrente"). ${ }^{43}$

El tiempo transcurre para los mexicas como un vivir siempre en el tiempo originario, pero cada vez nuevo. Contiene los elementos que los dioses enseñaron, las acciones que ellos hicieron para la existencia del mundo, pero también los actos de los seres humanos.

Permanencia y creación en un tiempo de existencia doble. La creación del mundo pasó por varias etapas, de

43 Tena, Rafael. Ibid., p. 12. 
creación y destrucción, de mejoramiento a cada una de las épocas.

La historia de los antiguos pobladores mexicanos se ha construido a partir de varios documentos llamados códices que han sobrevivido al paso del tiempo. Entre ellos están: el códice Vaticano y el códice Chimalpopoca que comprenden varios manuscritos en los que se encuentran datos que han permitido un acercamiento a las culturas prehispánicas.

Existen otros códices, como el Borgia y el FejérváryMayer, además de otros documentos que complementan la información, y en general los expertos coinciden en que los nahuas dividieron las creaciones y destrucciones del mundo en cinco soles o épocas.

"Primera creación. 4 Océlotl ("jaguar o tierra”) fue su nombre. Tezcatlipoca era el sol. El mundo estaba habitado por gigantes. Después de siete veces cincuenta y dos años, los jaguares le pusieron fin devorando a los gigantes.

Segunda creación. 4 Ehécatl ("viento") fue su nombre. Quetzalcóatl era el sol. Después de siete veces cincuenta y dos años le pusieron fin unos vientos terribles que se llevaron las casas, los árboles y las personas. Los pocos supervivientes se volvieron monos.

Tercera Creación. 4 Quiáhuitl ("lluvia o fuego") fue su nombre. Tláloc era el sol. Después de seis 
veces cincuenta y dos años terminó lloviendo fuego del cielo y formándose lava (erupciones volcánicas). El sol quemó todas las casas. Las gentes eran niños, y los supervivientes se volvieron pájaros.

Cuarta Creación. 4 Atl ("agua") fue su nombre. Chalchihuitlicue era el sol. Después de trece veces cincuenta y dos años terminó por inundaciones. Las montañas desaparecieron y las gentes se volvieron peces. Según una versión, sobrevivieron dos personas porque Tezcatlipoca les ordenó hacer un agujero en el tronco de un ahuehuete muy grande y meterse dentro cuando se cayeran los cielos. La pareja entró y sobrevivió a las inundaciones. Después enojaron a Tezcatlipoca, quien los transformó en perros cortándoles la cabeza y pegándosela a las posaderas.

Quinta Creación. 4 Ollin ("movimiento") fue su nombre. El dios del sol, Tonatiuh, era su sol. Un temblor de tierra le pondrá fin. Fueron hechos los hombres con huesos sacados del reino del inframundo, del dios de la muerte, por Quetzalcóatl. La sangre que sacó de su cuerpo cayó en los huesos y les dio vida a los hombres de esta época. La primera pareja era Cipactónal y Oxomoco.

Los dioses crearon a cuatro hombres, y Tezcatlipoca y Quetzalcóatl se volvieron grandes árboles. ${ }^{44}$

${ }^{44}$ Thompson, J. Eric S. Historia y Religión de los Mayas, pp. 399-400. 
Estas sucesivas creaciones nos permiten ver una cierta evolución, además de que tocan el número sagrado 4 , que serían las esquinas del mundo y un centro, el del Eje Cósmico que completaría el número cinco de las creaciones. Fue necesario pasar por las cuatro etapas que no estaban completas y que adolecían de varios defectos.

En el quinto sol, ya todo estaba preparado para que la humanidad surgiera de los huesos que el dios sacó del inframundo y combinados con la sangre de los dioses, saliera a poblar la superficie y a contribuir con el flujo continuo entre los diferentes estratos de lo existente; lo cielos, la tierra y el inframundo. Este comienzo del nuevo ciclo hace que todo esté conectado y el movimiento, la acción en el mundo, se daba gracias a la lucha de los opuestos.

El movimiento era muy importante para los mexicas, el símbolo "ollin" representa el momento cuando el chorro de fuego se entrelaza con el chorro de agua y forman un símbolo que aparece en la cerámica, el tejido, los murales, la música, la poesía y muchas otras representaciones de la cultura y comunicaban al individuo una realidad cósmica perenne que tenía lugar en todo momento y de la que eran parte los seres humanos. 


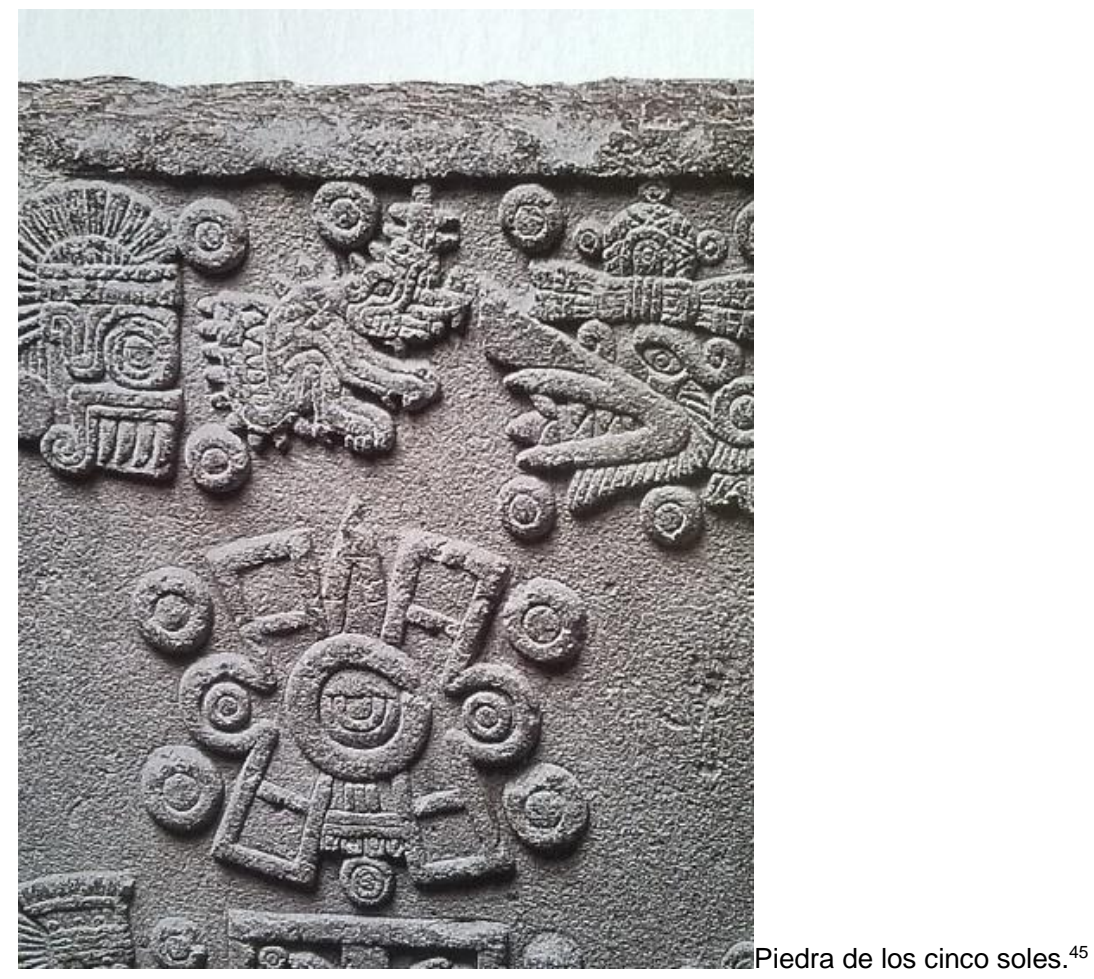

Para los mexicas, el origen del mundo se da a partir de la actividad de los dioses. Tezcatlipoca y Quetzalcóatl son considerados como los dioses que toman acciones para la creación del mundo terrestre. El tiempo originario y el tiempo actual están conectados en un continuo suceder; hay un patrón recurrente, pero los hechos no vuelven a repetirse. El tiempo tiene un carácter sagrado, siendo como fue, obra de los dioses.

El mundo para la creencia mexica, se imaginaba a partir de los elementos que tenían alrededor. No hay sólo un

${ }^{45}$ Arqueología Mexicna. Mitos de la Creación, p. 25. 
mito, pues varía según el tiempo y el lugar, pero en general se consideraba a la tierra como una superficie arrugada, como el lomo de un cocodrilo, y estaba rodeada de agua. La tierra era la parte intermedia entre el cielo y el inframundo estaba formado por la cabeza del lagarto, y su cola subía hasta el cielo formando una fronda florida. Tenochtitlan, su ciudad, era considerada el centro del mundo.

Cada suceso del mundo se había creado por estas luchas entre los dioses opuestos. El momento de la creación conjugó los resultados de esas luchas y por eso hay días y noches, luna y sol, lluvia y sequía, etc., con sus consiguientes dioses particulares. ${ }^{46}$

Los mitos no se enlazan de la manera en que enlazamos nosotros nuestra historia, tienen un tiempo independiente y peculiar, muy distinto a la temporalidad a la que estamos acostumbrados en nuestra sociedad actual. Los dioses habían creado al humano para que hubiera un intercambio, el sacrificio divino para la creación, debía pagarlo el ser humano con ofrendas. Los dioses se agotaban al mantener el mundo en movimiento y por eso la humanidad debía fortalecerlo con dichas ofrendas.

Existía un doble tiempo y espacio; el primero pertenecía a los dioses y habitaban en él, el segundo era el de los seres humanos, pero los dioses podían actuar ahí

46 López Austin, Alfredo. Op. Cit. P. 248. 
también. El ser humano puede inclinar la voluntad de los dioses a su favor por medio de ofrendas y oraciones.

El mundo existe gracias a la lucha de los dioses, el sol se mueve debido al continuo enfrentamiento de dos fuerzas opuestas pero complementarias, la femenina y la masculina, lo frío y lo caliente, la luz y la oscuridad. ${ }^{47}$

En la estructura del mundo y de todo lo existente se puede ver que los mexicas consideraban distintos niveles de creación: Los cielos donde moraban los dioses, existían arriba de la tierra de los humanos y abajo de ella existían los inframundos y eran en total 13 niveles. También había cinco rumbos de la tierra: lo masculino (el este), lo femenino (el oeste), la muerte (el norte) y la vida (el sur), y el centro que era el ombligo del mundo. Cada uno de ellos tenía asignados su color, sus dioses, días, y varios otros atributos. ${ }^{48}$

Los aztecas consideraban al ser humano como parte sustancial de la existencia del mundo, pues tenían que realizar acciones que aseguraran el contento de los dioses para que el mundo siguiera recibiendo su alimento y el aliento divino.

La cosmovisión mesoamericana era compartida y a veces impuesta por un gran número de pueblos que habitaron en esa gran área, pero cada pueblo le ponía los detalles

47 Id. p. 250.

48 Tena, Rafael. Op. cit., p. 18. 
de acuerdo a su cultura y a su medio. Básicamente descansaba en el dualismo; todo lo que existía estaba regido por dos fuerzas opuestas y complementarias, y el mundo de los dioses no se escapaba de ello.

La mentalidad mesoamericana concibe la existencia en el aquí y ahora, pero al mismo tiempo en el allá-entonces, como nos menciona López Austin.

\begin{abstract}
"El destino era una combinación de fuerzasdioses-tiempos que coincidían en un momento dado. Las fuerzas-dioses-tiempos eran combinaciones, porque al carácter divisible de los dioses hay que sumar el de sus posibilidades de fusión y fisión. Según la concepción mesoamericana, varios dioses podían fundirse en uno sólo, y cada uno de ellos podía separar sus atributos para crear distintas individualidades divinas. Cada día, por ejemplo, era la unión transitoria de al menos dos dioses. La fusión podía llegar a la totalidad divina." ${ }^{49}$
\end{abstract}

Los colores también tenían una significación simbólica, aunque sus variantes son muchas por la gran cantidad de grupos que pertenecían a esa herencia, y eso se reflejaba en las concepciones de los dioses y las regiones, cada una tenía su color.

49 López Austin, A. Op. Cit., p. 248. 
La vida cotidiana también se insertaba en esa pertenencia $y$ los colores puestos en las prendas tejidas las relacionaban íntimamente con lo sagrado. No solamente las figuras, sino cada color estaban profundamente ligados con un simbolismo mágico y religioso, así como también los demás elementos de la actividad textil.

El tema de los nudos y las cuerdas como simbolismo en la iconografía mesoamericana ha sido abordado por dos investigadoras: Teresa E: Rohde y Cecilia F. Klein, quienes han percibido la importancia del tejido en la visión prehispánica de la creación del mundo.

Klein, investigadora estadounidense, aborda el tema desde fuentes primarias y secundarias en las cuales hace notar que las expresiones utilizadas para describir la conformación del mundo y ciertos rituales hacen referencia a hilos, cuerdas, nudos y telas, por lo que avanza la hipótesis de que en Mesoamérica se concibió el cosmos como un tejido que está formado por hilos que a su vez permiten la comunicación entre los distintos niveles del cosmos pensados por los aztecas y mayas. ${ }^{50}$ Los nudos y los hilos enredados que quedan al reverso de un tejido, representarían el inframundo, en contraposición

\footnotetext{
50 Cecilia F. Klein "Woven Heaven, Tangled Earth. A weavers paradigm of the Mesoamerican Cosmos". Ethnoastronomy and Archaeoastronomy in the American Tropics Series of Annals of the New York Academic Science. Vol. 385:1-35. New York 1982.
} 
con los niveles superiores que serían la parte bien elaborada del textil.

Klein habla de una concepción en la que se piensa que la tierra está tejida y que como el mar se extiende por debajo de la tierra, los diversos conductos llevan a que el agua salga donde hay hoyos en el tejido. En su artículo "Woven Heaven, Tangled Earth: A Weaver's Paradigm of the Mesoamerican Cosmos", trata el tema, y en la imagen siguiente podemos ver cómo se conformaba.

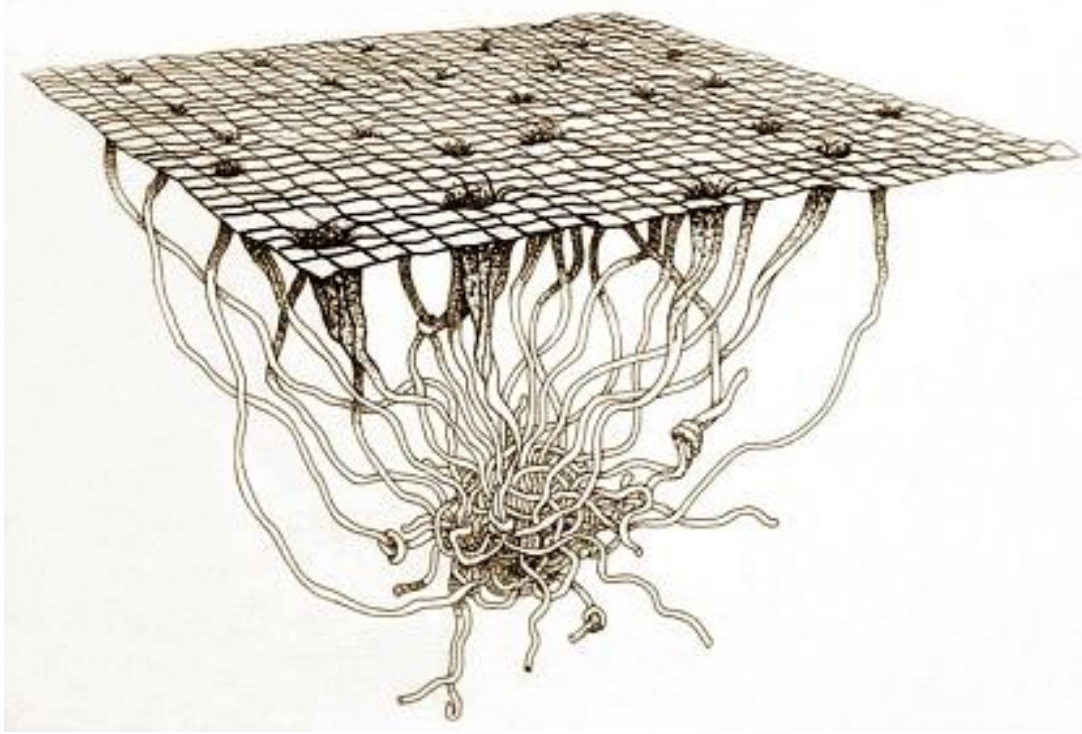

Dibujo de la conformación de la tierra, por Henry F. Klein. Tomado de http://www.mexicolore.co.uk

Al ver la imagen anterior nos podemos imaginar incluso las chinampas aztecas, que eran tejidos sobre los que se ponía tierra para cultivar plantas sobre el agua. 
Especialmente el dibujo nos presenta la situación de Yucatán, región maya que es plana y en donde abundan los cenotes que son pozas de agua dulce que surgen de los ríos subterráneos.

Rohde tiene varios artículos refiriéndose al simbolismo de las cuerdas y los nudos en la cultura mesoamericana y menciona

“...el tejido como actividad típica de las deidades creadoras que manejan la urdimbre y la trama para establecer, mediante la primera, el principio de lo divino, lo masculino, lo eterno $y$, mediante la segunda, la trama, representar lo humano y lo contingente, de lo cual se colige que el destino de cada individuo se da en el punto en que ambas líneas se cruzan, y por eso las hilanderas son diosas del destino en las diversas mitologías." 51

Rohde ha estudiado también el simbolismo de las cuerdas $y$ ha reafirmado que son el medio que une la tierra y el cielo y además habla de la telaraña como esquema cósmico y ha identificado figuras que representan una especie de red cósmica en donde se desenvuelve el drama de la creación. Esta investigadora mexicana plantea varias cuestiones que se derivarían del modelo de universo tejido.

51 Rodhe E., Teresa. El tejido del cosmos: residuos de un mito perdido, p. 279. 
Habría que ver si este concepto abarca todos los pueblos de Mesoamérica. La investigadora se pregunta de qué material estaría hecha esa red y cómo afectaría esa concepción a otras áreas del pensamiento prehispánico.

Es necesario un estudio más acucioso y profundo al respecto, pues me parece que existen los elementos para afirmar lo que esas dos investigadoras han encontrado y pudieran rastrearse datos y notas para confirmar la aseveración sobre la creación como tejido y la unión por medio de cuerdas, que es totalmente evidente en la iconografía.

Las cuerdas son de común representación en el simbolismo prehispánico; una de las representaciones aztecas de la lucha de los opuestos en el eje cósmico está representada por dos cuerdas unidas en torzal, una que sube y es de agua y la otra baja formada por el fuego. Es un símbolo que se ve en muchos de los murales y cerámica y que es común en la vestimenta y se sigue tejiendo hasta la actualidad, aunque los tejedores actuales ya no son depositarios de su profundo contenido.

Me parece que también está pendiente un estudio acerca de las semejanzas de la iconografía del mito de la creación y del funcionamiento del mundo con las grecas que aún se conservan en los tejidos indígenas; creo que dicha iconografía podría encontrarse estilizada en los adornos tejidos de la vestimenta, tanto en los muros, 
códices y estelas, como en los adornos que aún perviven en los textiles indígenas modernos.

En Perú se han hecho estudios serios al respecto por parte de Gail Silverman, investigadora que ha encontrado todo un sistema de comunicación en los textiles antiguos y modernos de las comunidades indígenas peruanas, en su libro El tejido andino: un libro de sabiduría.

En estas imágenes podemos apreciar la similitud de la pirámide en espejo con la estilización de un tejido en la bocamanga de un sarape de principios del siglo XX.
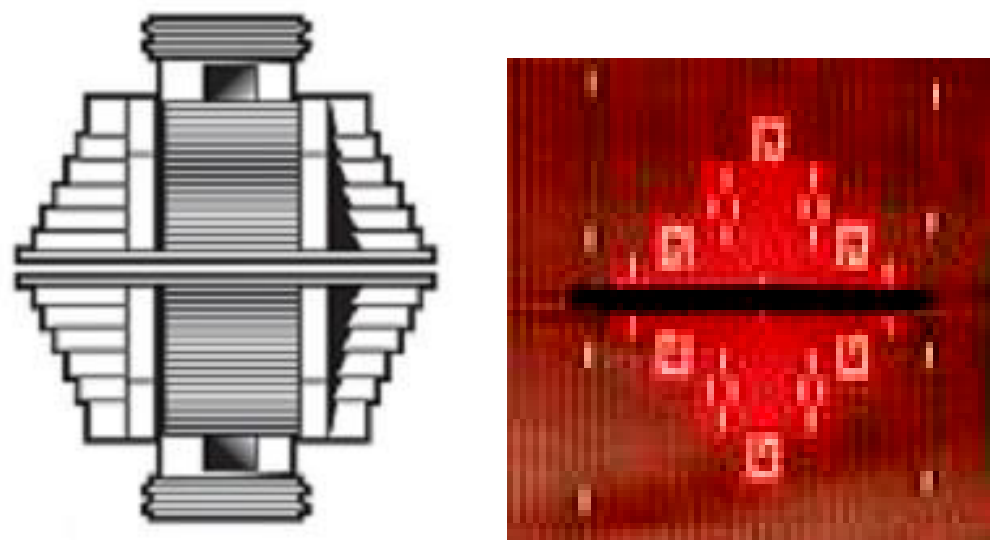

Foto de Eduardo Cantú. ${ }^{22}$

La simbología guarda la exactitud de los descubrimientos, lo que vemos como simples grecas o figuras míticas, tenían un significado que se puede develar con las

52 Tomada de http://www.mexicolore.co.uk/index Graphic by Debs Tyler. 
investigaciones que los estudiosos le han dedicado al tema. $\mathrm{Y}$ aunque ese antiguo sistema de ideas ya no nos pertenece, podemos rastrear la significación en los dibujos que se conservan en la cultura indígena actual. Ya no tienen el mismo significado, porque como dice Ricoeur:

\begin{abstract}
"Las imágenes del sistema antiguo, sólo pueden sobrevivir como flores truncadas. El curso de las imágenes es continuo; el de las "significaciones", no. Otro sistema de "significaciones" se va asimilando e incorporando a las mismas representaciones." ${ }^{3}$
\end{abstract}

Existen otras significaciones en la actualidad, pero al estudiar la cultura antigua es posible acercarse un poco a la significación original. Cada templo construido, cada imagen de los dioses, cada piedra en la que dejaron su testimonio ha resultado ser más que una cuestión de manifestación artística de las culturas Mesoamericanas.

Cada glifo nos lleva a una coherencia y correspondencia con la estructura creada por esta cultura y que explica el por qué de todas las cosas; todo en base a las observaciones astronómicas que hicieron y que sustentan sus creencias sobre el universo y el mundo en que vivían. Todo es un reflejo y consecuencia del movimiento del cosmos, del tránsito de las estrellas sobre el cielo, de la

${ }^{53}$ Ricoeur, Paul. Finitud y Culpabilidad, p.355. 
exactitud de los cálculos sobre los ciclos naturales del planeta.

Los científicos se han dado cuenta, no sin cierto estupor, de que la cultura azteca no era simplemente una cultura arcaica que resolvía la vida día a día. Tenían un elaborado sistema que les permitía sustentar su extenso poder sobre los demás pueblos y a la vez les daba la certeza de los ciclos para la agricultura y dicho sistema explicaba las relaciones de los gobernantes con los dioses (planetas), que regían el orden del universo.

Tenían además predicciones exactas de los tiempos en que se debían realizar las actividades que permitieran el funcionamiento del mundo. Todo esto con base en los cálculos que habían hecho respecto del movimiento de los planetas y estrellas y que se acercan impresionantemente a los cálculos modernos.

El ser humano siempre ha querido y necesitado poner un orden al mundo que lo rodea. Clasifica por ello, las fuerzas y elementos que percibe, observa y analiza. El contacto continuo y cercano con la naturaleza permitió a las culturas mesoamericanas establecer el orden que explicaba su realidad. En la cultura mexica también se tomaban en cuenta las características o propiedades de las cosas. Lo seco, húmedo, frío, caliente, oscuro, luminoso, masculino, femenino, etc., eran duplos que se 
oponían y al establecer relaciones entre ellos daban lugar a la actividad de las fuerzas de la naturaleza.

\begin{abstract}
"Es necesario aclarar que en la antigüedad mesoamericana no se contaba entre estas oposiciones la del bien y del mal, que es tan característica en otras religiones del mundo." 54
\end{abstract}

Esto es un hecho a resaltar, porque el juicio moral no era importante, lo importante era la acción humana para el funcionamiento del universo. Si se siguen esos conceptos en dicha cultura, se podrá ver la relación de cada estrato de la realidad con la concepción mítica que explica dicha realidad. Hay una interrelación entre cualquier situación humana y las energías del cosmos. Había que conservar cierto equilibrio para que todo funcionara adecuadamente. También es necesario saber que dichos estados de la materia y las cualidades de los objetos no corresponden necesariamente a lo que entendemos actualmente, -por poner un ejemplo-, como caliente o frío. El ejemplo más extremo que cita López Austin es el del granizo que era considerado con propiedad de caliente para los antiguos mexicanos.

${ }^{54}$ López Austin. Los dioses..., p. 35. 
De este modo, podemos ver que aún teniendo las fuentes, es necesaria una mejor inmersión en los conceptos culturales para no juzgar tan a la ligera a estas culturas. La dualidad dinamiza todo lo existente y permite que haya el equilibrio gracias a las luchas entre los opuestos. Desde la realidad cotidiana en la cocina hasta la creación del mundo por el padre y la madre primordiales, la dualidad se manifiesta como el complemento perfecto para la existencia del mundo. De hecho, fray Juan de Torquemada en uno de sus registros habla de que la pareja primordial Ometecuhtli (masculino) y Ometecíhuatl (femenino) eran a su vez dos cada uno, por lo que también les nombraban el Señor dos y la Señora dos. La duplicidad de los dioses primordiales dejaba ver cuán importante era para ellos la dualidad.

Y todo lo existente tenía carácter divino por cuanto existía en el tiempo de los dioses, antes de que siquiera la humanidad fuera creada. De ahí el profundo respeto por todo lo existente y la importancia de las acciones del individuo en la sociedad, en la naturaleza o en cualquier oficio que se propusiera. Por esto los dioses pueden ser muchos, ya que cada aspecto de la vida está regido por una deidad.

Y cada uno de esos dioses tiene dos o más aspectos que le permiten incidir sobre la parte del mundo que gobiernan. Los dioses satisfacen las necesidades 
mundanas de los seres humanos, pero también el humano necesita satisfacer las demandas divinas. Este elemento importantísimo se debe tener en cuenta de manera puntual, porque define, a diferencia de nuestra situación actual, la reciprocidad que había entre el mundo humano y el divino.

En el tiempo de los dioses, también había acciones que definirían el mundo; por ejemplo la condena que recibieron los hijos del dios padre y la diosa madre, de irse a vagar por el inframundo y de poblar la tierra debido a que cortaron flores y ramas del árbol de Tamoanchan, un árbol divino. $\mathrm{Y}$ a pesar de que esto suene como influencia cristiana, existen códices previos a la conquista que ilustran el hecho.

Otro ejemplo que nos pone López Austin es cuando los gemelos del mito maya trataron de capturar al venado y al conejo y se quedaron con una parte de la cola entre las manos por lo que ambos animales quedaron rabicortos para toda la posteridad.

El Monte Sagrado del que nos habla este autor es el contenedor tanto de fuerzas como de objetos que tomarán vida en el mundo exterior. Todo tiene un por qué y cumple con la función que le toca.

Las semillas-corazones provienen del Lugar de la Muerte. Son la parte divina de las criaturas que fueron destruidas en el 
mundo por el paso del tiempo. Del Lugar de la Muerte pasan a la gran bodega del Monte Sagrado, y de la bodega suben por el tronco del Árbol Florido para convertirse en los frutos que se derraman, de nuevo, sobre la superficie terrestre. El Eje Cósmico es, por tanto, el gran motor del mundo. ${ }^{55}$

Desde el castigo de los hijos de los dioses, estos dones guardados en el Monte son dados a la raza humana y se establece este circuito donde la tierra recibe lo mortal y de ella sale la vida, las nubes, los ríos, Es importante destacar que el inframundo o los niveles situados debajo de la tierra, llamados el Mundo de los Muertos, no tiene la connotación de maldad y castigo que tiene la concepción cristiana.

Antes al contrario, del inframundo salieron los huesos que formaron a los humanos, las semillas que dio el dios a los seres humanos, el agua que fertiliza y verdea la tierra; además de ser el lugar a donde van algunos de los hombres que murieron en ciertas circunstancias y no para ser castigados, sino porque la naturaleza de su muerte les reserva el honor de estar al lado de los dioses pertenecientes a esa zona.

En la cultura mexica, todos los alimentos que consume el ser humano salieron de una montaña que los cuatro dioses rompieron $y$ se menciona que fueron

${ }^{55}$ López Austin. Dioses..., p. 56. 
principalmente maíces de cuatro colores, que cada grupo de dioses tomaría un color como distintivo y debido a eso son cuatro tipos de lluvias que ayudan o no a las cosechas.

En la siguiente imagen se puede ver "el cultivo de la tierra y el culto a las fuerzas del sector femenino del cosmos. Dentro de la montaña sagrada hay un depósito de agua representada aquí con círculos concéntricos), fuerzas de germinación y crecimiento (representadas como serpientes) y "corazones" o espíritus de las plantas (representados como corazones): a) El agricultor invoca a los dioses de la lluvia y siembra la semilla; los dioses conceden sus dones. Bajo la tierra se unen la semilla sembrada, las fuerzas, el agua y el "corazón" del maíz, con los que se inicia la vida de una nueva planta. b) Tras la cosecha, el agricultor da gracias a los dioses; las fuerzas y los "corazones" regresan al depósito de la montaña; el humo de la quema de rastrojo lleva el agua a su origen subterráneo. ${ }^{56}$

${ }^{56}$ Arqueología Mexicana, La mujer en el mundo prehispánico. p. 12. 


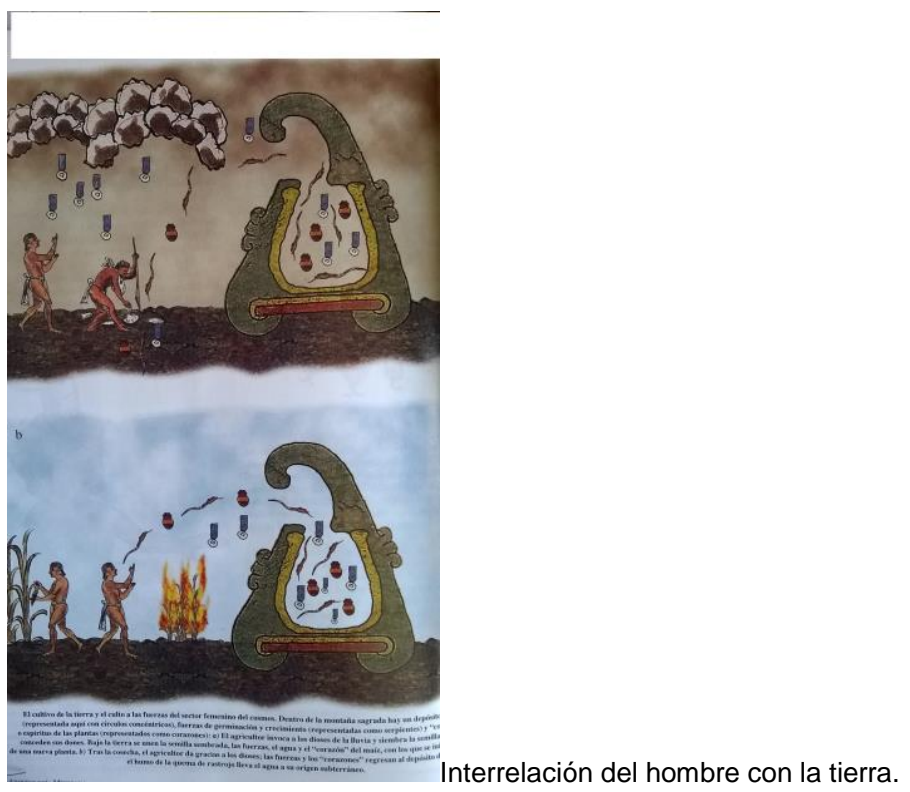

El Eje Cósmico que está en el centro también se desdobla y crecen 4 árboles en las esquinas del mundo. Esta figura también se reproduce en los diseños que se estampan en su cerámica y sus textiles.

Los dioses mesoamericanos existen en su propio mundo pero comparten las características de los seres humanos. Están presentes y rigen toda actividad humana, pero no se pueden ver directamente, por lo menos no en el estado normal de vigilia. Tienen una parte impredecible que obliga a los individuos a que actúen para agradarles y no molestarlos. 


\section{EL MITO MAYA DE LA CREACIÓN}

Ésta es la relación de cómo todo estaba en suspenso, todo en calma, en silencio; todo inmóvil, callado y vacía la extensión del cielo. (...) Llegó aquí entonces la palabra. Vinieron juntos Peru y Gucumare, en la oscuridad, en la noche $y$ hablaron entre sí Tepeu y Gucumatz. Hablaron, pues, consultando entre sí y meditando; se pusieron de acuerdo, juntaron sus palabras y su pensamiento.

\section{Popol Vuh}

La civilización maya ha cobrado mayor importancia en las últimas décadas. Sus descubrimientos en los ámbitos de arquitectura, medicina, astronomía, matemáticas, hidráulica, etc., les permiten contarse ante los ojos de los expertos de la actualidad, como una de las culturas más avanzadas, comparables a las civilizaciones tales como la de Egipto o Mesopotamia.

Los mitos mayas de la creación se han conservado tanto en documentos como en las inscripciones en los sitios arqueológicos, además de en la cultura de los grupos mayas actuales. Debido a que existen todavía cinco millones de pobladores mayas, los detalles cambian 
según el grupo al que pertenecen, pero los arqueólogos han podido establecer que las líneas generales se han conservado desde los tiempos prehispánicos, aunque adaptándose a los tiempos, por lo que la etnología es parte importante para el entendimiento de esta cultura de orígenes tan antiguos.

La observación del cielo en todas las culturas, por su función para conocer las temporadas que eran propicias para la agricultura, era de crucial importancia. La cultura maya no fue la excepción y la observación del cielo y el movimiento cíclico de los astros les permitió tener cálculos que hacían posible medir el tiempo con conocimientos exactos y al considerarse el cielo una cosa invariable se convirtió en el eje sobre el que se construyeron las concepciones míticas del origen.

En la actualidad es la arqueoastronomía quien se ocupa del análisis de la transformación cultural de las cuestiones astronómicas en las diferentes sociedades a lo largo de la historia.

Los estudiosos han avanzado mucho en el desciframiento de las pinturas o los glifos mayas, pues se ha encontrado que las inscripciones no sólo se tratan de fechas calendáricas, sino que tienen que ver con la actividad de los sacerdotes o reyes relacionada con las actividades de diferentes dioses. 
...el estudio de los elementos astronómicos en las inscripciones no ha perdido relevancia; al contrario, los avances en el desciframiento de la escritura posibilitan interpretaciones cada vez más calificadas, relacionada con el contexto cultural y, por tanto, importantes para la comprensión global de la sociedad maya." ${ }^{57}$

La astronomía permitía tener conocimiento de ciertos fenómenos celestes y cambios o períodos climáticos, por lo que su conocimiento dentro de la sociedad maya era de capital importancia. Los sacerdotes o gobernantes estaban obligados a conocerla y así podían utilizar la conexión con la religión como un aparato que permitía que fueran superiores a la masa social. Lo que se sabía de astronomía estaba relacionado con la cosmovisión de las culturas mesoamericanas y también se manejaba por los gobernantes para refrendar su conexión más directa con lo divino.

Para los antiguos mayas, el mundo divino y el mundo terrenal estaban indisolublemente unidos. El orden del universo abarcaba tanto al universo como al entorno humano. A través del estudio de las diversas claves dejadas por estas sociedades, se ha podido descifrar el sistema ideológico y sus concepciones sobre lo que los rodeaba. Ellos estudiaron los astros y el funcionamiento

${ }^{57}$ Spraj, Ivan. en Aspectos fundamentales..., p. 278. 
de la naturaleza y elaboraron un sistema cosmológico que era la base y roca de toda su estructura social. El sistema del universo era activo, no funcionaba autónomamente y los seres humanos jugaban un papel primordial para que este engranaje se mantuviera en movimiento.

Toda la estructura de la sociedad, sus actividades, la vida personal y familiar, la búsqueda de conocimientos, eran tremendamente necesarios para que el cosmos siguiera existiendo. El ser humano tenía que cumplir los deberes que le tocaban para evitar que un desequilibrio cosmológico le acarreara enfermedad, sanciones o incluso la muerte. Los dioses necesitaban de la acción humana para mantener el orden del universo. Para los mayas no existía la división entre los mundos naturales y los sobrenaturales y todo lo que existía era parte de la misma totalidad por eso dice Sharer:

En la medida en que todos los dioses mayas eran aspectos de la misma potencia, el reino maya de lo sobrenatural puede ser considerado monoteísta, En tanto que cada aspecto se podía representar de distinto modo, y definir como deidad individual, el reino maya de lo sobrenatural puede también ser considerado politeísta. ${ }^{58}$

58 Sharer, R. La Civilización Maya, p. 502. 
Los dioses reúnen varios atributos que los distinguen y les dan su característica divina, pero nuestra tradición occidental de esquemas dificulta la claridad en cuanto a su clasificación. Se quiere que entren en una clasificación clara y distinguible, pero eso crea confusiones para entender cabalmente el panteón maya. La multiplicidad de atributos y el simbolismo de cada uno de ellos, tales como el color, las partes de animales que forman su representación, la dirección, la edad o los utensilios que los distinguen, enriquecen la figura de los dioses mayas y complican a la vez someterlos a las clasificaciones a las que estamos tan acostumbrados.

Las múltiples creaciones sirvieron para perfeccionar el trabajo de los dioses. Y la eterna lucha entre la dupla del bien y del mal, era un eje central de la ideología maya. Esta pugna modificaba el destino de la humanidad y los enfrentaba con épocas buenas y malas. La dualidad es también un símbolo muy importante entre los mayas. ${ }^{59}$ Los humanos más importantes fueron los Gemelos que pudieron enfrentarse a los dioses de la Muerte y salieron victoriosos.

Uno de los libros más importantes para la conservación y el estudio de la cultura maya, es el Popol Vuh, que registra los mitos de la creación tal como los vieron los

59 Sharer, R. Op cit., p. 499. 
mayas quiché de las tierras altas de lo que hoy es Guatemala.

Según describe dicho libro, existió una pareja creadora, donde al principio masculino se le nombraba Ixpiyacoc y a la parte femenina Ixmucané. Ellos crearon el primer universo, dividiendo en partes con la cuerda y lo describen así:

...los cuatro lados, los cuatro rincones, que medían, repartían en cuatro partes, compartiendo la cuerda, extendiéndola en el cielo, sobre la tierra, en los cuatro lados, en los cuatro rincones como fue dicho, por el Creador, el Modelador, madre y padre de la vida, de la humanidad, quien da aliento y corazón, el portador, que eleva, a la luz perdurable, a los nacidos en la luz, engendrados en la luz; quien medita, quien conoce todo, todo lo que existe, el cielo tierra, los lagos y el mar. ${ }^{60}$

Se narra en el libro cómo se fueron formando las cosas por medio de la palabra, pues bastaba a los dioses pronunciar la palabra tierra para que ésta surgiera y se creara. Así crearon todo lo que existe en el universo y en

${ }^{60}$ En Freidel, et al. El Cosmos Maya, p. 105. 
la naturaleza. Pero faltaba algo que fuera testigo de la maravillosa creación de los dioses, y se crearon los animales, pero éstos no podían hablar ni alimentar a los dioses, por lo que decidieron crear al ser humano.

Fueron cuatro los intentos que se hicieron: el primer intento de formar la figura humana se hizo en barro, pero eran demasiado blandos y se deshacían. Luego vino otro intento con madera, pero no podían acordarse de sus dioses y no cuidaban a los animales, por lo que se envió una inundación para acabar con ellos y se transformaron en monos.

Luego vino la tercera creación y se hicieron los héroes gemelos Hunapú e Ixbalanqué que tuvieron que vengar la muerte de su padre a manos de los señores de Xibalbá o el inframundo. Corrieron varias aventuras en las cuales pudieron derrotar a dichos señores y resucitaron a su padre. La batalla final que libraron fue contra 7Guacamayo, que era un ave maravillosa con la arrogancia de creerse el sol. Los hijos de esta ave, mataron a 400 muchachos y crearon así las Pléyades, constelación importante en la cosmología maya. Los gemelos se identifican con el sol y la luna.

Después de esto se preparó la cuarta creación, que es la que vivimos actualmente. La pareja creadora Ixpiyácoc e Ixmucané, pensaron que los siguientes seres humanos debían ser perfectos, y los hicieron de maíz blanco y 
amarillo. Ixmucané molió los granos nueve veces y modeló los primeros 4 seres humanos cuyos nombres eran: Jaguar-Quitzé, Jaguar-Noche, Mahukutah y Verdadero Jaguar.

Ellos podían ver todo como los dioses, eran así de perfectos. Por eso los dioses se arrepintieron de haberlos creado tan parecidos y con las mismas facultades que ellos y decidieron que formarían un velo ante su vista para que no pudieran ver todo tal como es, sino que tuvieran que voltear hacia los dioses en busca de explicaciones.

De esta manera quedó establecido el mundo, y los seres humanos comenzaron a poblar la tierra y a cumplir con su tarea de alimentar a los dioses y adorarlos. Todo esto se escribió en la bóveda celeste de tal manera que los seres humanos lo pudieran leer en las siguientes generaciones y se construyó el mapa del cielo, donde coinciden los mitos con la posición de las estrellas y el movimiento de los astros.

Los astroarqueólogos han descifrado muchas de las claves de esta lectura del cielo que hicieron los mayas patentes en sus mitos, con una exactitud que toma en cuenta incluso la precesión astronómica.

Los estudios que se han hecho sobre la cultura maya durante más de un siglo, permitieron encontrar las líneas que condujeron a los descubrimientos realizados en la década de los noventa. Los expertos han encontrado que 
los elementos de la cosmología maya llevan a cuatro temas centrales básicos en la comprensión del mundo:

...la creación del cosmos; el ordenamiento del mundo de los seres humanos y de los dioses y los antepasados del Otro Mundo; el triunfo de los seres humanos ancestrales sobre las fuerzas de la muerte, la descomposición y la enfermedad, por medio de la astucia y del engaño; el milagro del verdadero renacimiento a partir del sacrificio, y los orígenes del maíz como sustancia del cuerpo y del alma mayas. ${ }^{61}$

La comunicación entre los expertos mayistas que se facilita gracias a la tecnología moderna, ha permitido construir una visión integral que coincide tanto en el Popol Vuh, libro sagrado de los mayas, como en lo que se ha descifrado en las construcciones, y en los códices que existen.

En el mito maya, según las inscripciones de los templos, la creación empieza con la palabra y entonces aparece la materia que es nombrada por esa palabra.

${ }^{61}$ Freidel, David, et al. El cosmos maya. P. 39. 


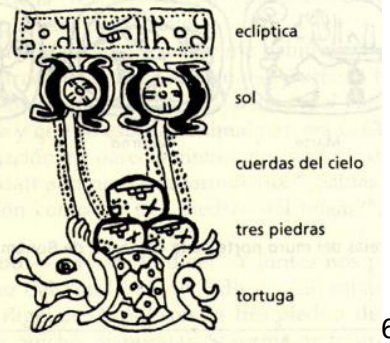

La primera acción que se realiza en la creación del universo, es la colocación de tres piedras qque se identificaron con las tres estrellas de la constelación de Orión) que centran el cosmos, y estas son las que permitirán que el cielo se eleve, pues antes de esto la tierra y el cielo estaban juntos y no había luz. Así que los dioses trabajaron juntos para crear el mundo. Como se puede ver en la imagen, las cuerdas comunican los cielos con la tierra.

En el Tablero de la Cruz se esculpió la historia de la creación y ahí se registra el nacimiento de la Primera Madre, años antes de la creación y días antes del nacimiento del Primer Padre. Se elevó el cielo por medio de la erección del axis mundi y se dotó de movimiento a las estrellas.

Los mayas basaban su cosmología en el movimiento de las estrellas y la posición de las constelaciones, y además se ha descubierto que incluso con la progresión que a lo

62 Freidel, David, et al. El cosmos maya, p. 78. 
largo del tiempo ha llevado a cabo el movimiento de traslación, sus observaciones eran exactas en el mapa del cielo. Esto ayudó a comprender las inscripciones que se encuentran en los vestigios arqueológicos.

La eclíptica, es decir, la línea de constelaciones en la que el sol sale y se pone durante todo el año, está representada en el mundo maya por una serpiente de dos cabezas que cruza el Árbol del Mundo ${ }^{63}$ y es el camino que el dios creador marcó para que lo sigan el sol y los planetas. Los estudios con programas de computadora que permiten visualizar el cielo como se veía hace miles de años, permitieron constatar la exactitud de los cálculos mayas expresados tan bellamente en sus construcciones y objetos ceremoniales.

Las representaciones que se han encontrado en los símbolos mayas, representan una parte del cielo real. La canoa de árbol de cocodrilo que se encuentra representada en los muros mayas, es la vía láctea y en su movimiento recrea el hundimiento de la canoa con sus remeros, jaguar y mantarraya; llevan al dios del maíz al lugar de la creación donde colocará las tres piedras y pueda renacer y crear el universo. ${ }^{64}$ Lleva los granos de maíz para poder construir el cuerpo de los humanos después de crear el cosmos donde habitarán.

\footnotetext{
63 Friedel, op. cit.

64 Idem., p. 90.
} 
Los remeros se designan con la palabra que se traduce como sabio y artista, porque esa categoría se le da a quien crea algo, a quien pone orden en el caos primordial de las cosas.

La elevación del cielo aún se puede observar en el transcurso de la noche, pues el movimiento de la Vía Láctea continúa recorriendo el camino trazado por el dios primordial de los mayas.

"La copa del árbol se abría paso más allá del corazón del cielo hacia el norte, en tanto que el escorpión se asentaba en la base del árbol por el sur." 65

Como vimos, en las inscripciones se pueden encontrar cuerdas que unen el cielo con otras imágenes, estas cuerdas celestes muestran el origen y el producto, los lazos que existen entre lo divino y lo creado. También representan cordones umbilicales que unen al creador con lo que se está dando a luz.

(...) había un camino colgante en el cielo, que iba de Tulum y Cobá a Chichen Itzá y Uxmal. Aquel camino se llamaba kuxan sum o sakbé. Tenía la naturaleza de una gran cuerda (sum) a la que se consideraba viva (kuxan), por cuyo centro corría

65 Idem., p. 97. 
sangre. A través de la aquella cuerda se enviaba alimento a los antiguos gobernantes que vivían en las estructuras actualmente en ruinas. Por alguna razón, la cuerda desapareció para siempre. Esa primera época fue separada de la segunda por una inundación llamada Halylkokab. ${ }^{66}$

Por lo menos dos investigadoras han estudiado la cuestión de las cuerdas y el tejido en los mitos mesoamericanos y mayas: Teresa E. Rohde y, mencionada también anteriormente, una profesora norteamericana llamada Cecilia F. Klein, quienes abordan el tema del simbolismo del tejido con sus hilos y nudos formando telas en la iconografía de las sociedades prehispánicas. Ellas plantean la posibilidad de que dichas culturas tuvieran como paradigma la existencia de un universo tejido y su funcionamiento como el de un gran telar.

Esta referencia a las cuerdas la podemos encontrar también en el Popol Vuh,

...los cuatro lados, los cuatro rincones, que median, repartían en cuatro partes, compartiendo la cuerda, extendiéndola en el cielo, sobre la tierra, en los cuatro lados, en los cuatro rincones como fue dicho

66 Idem., p 103. 
por el Creador, el Modelador,

madre y padre de la vida, de la humanidad,

quien da aliento y corazón,

el portador, que eleva, a la luz perdurable,

a los nacidos en la luz, engendrados en la luz;

quien medita, quien conoce todo, todo lo que existe:

el cielo tierra, los lagos y el mar. ${ }^{67}$

La cuerda que da aliento a todo lo que existe está representada nítidamente en los mitos mayas antiguos e incluso en los contemporáneos, aunque no se recuerde su antigüedad y el simbolismo mágico con toda su profundidad.

El ombligo del mundo, el centro del cielo, están conectados con esa cuerda que atraviesa todos los niveles de la creación y permite la comunicación de los dioses hacia los humanos y de éstos hacia el mundo de lo divino. La serpiente que surge del vientre del dios del maíz es esa cuerda que une el mundo humano con los otros niveles de existencia.

${ }^{67}$ Popol Vuh., p. 57. 


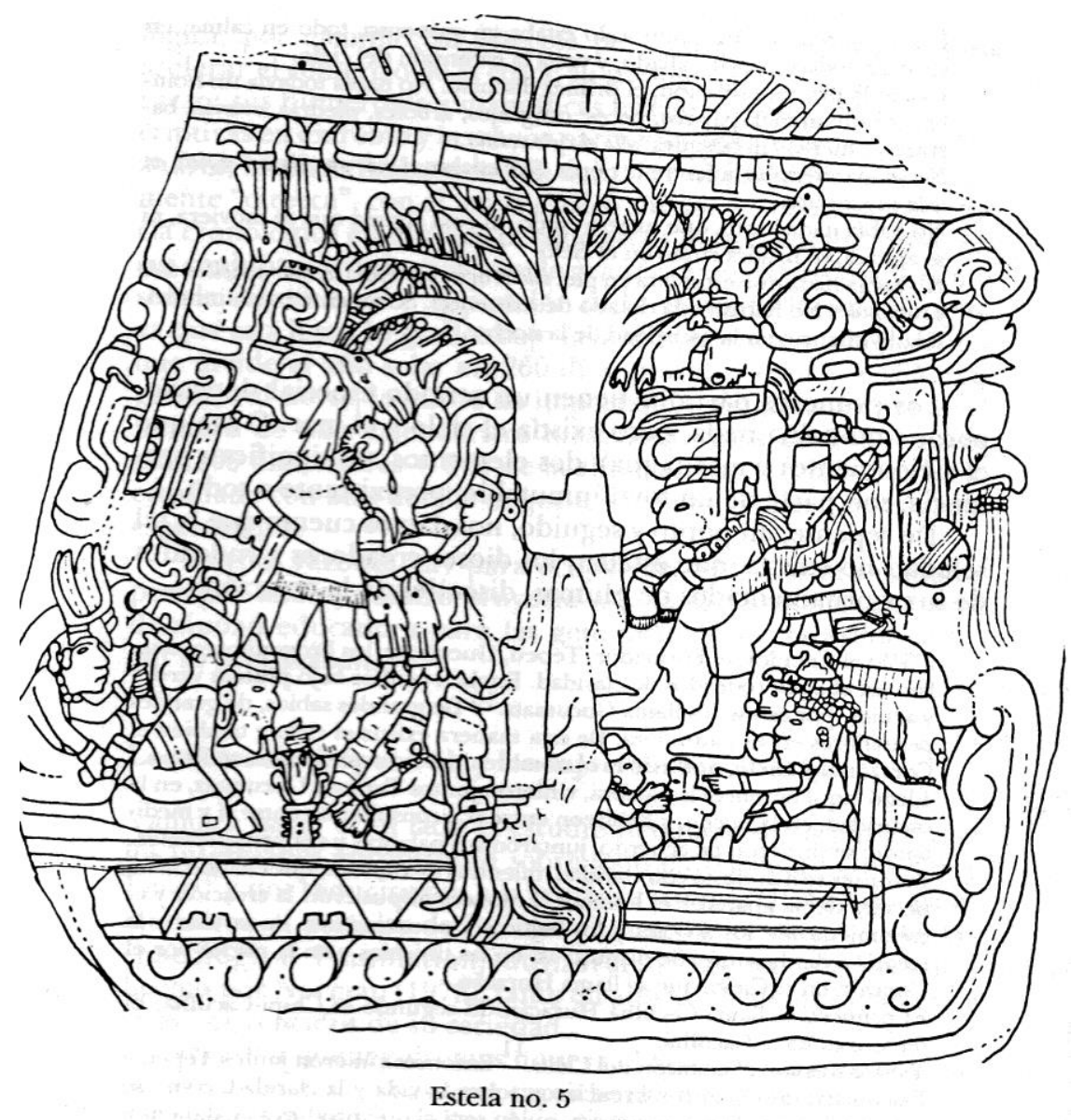

En esta imagen se muestran, según Beatriz Barba, los detalles de los orígenes.

“-En la parte inferior se ve el mar en calma que inicialmente envolvía todo, y que en la estela trata de cubrir hasta medio campo.

-Sobre el mar, y dentro de un rectángulo que trata de representar la tierra, hay montañas ya bien erectas y otras apenas señaladas; en medio, las 
raíces del árbol de los orígenes que (...) parecen símbolos de deidades celestes, lengüetas, colmillo, franjas, etcétera." 68

Esta cuerda fue cortada por sucesos externos al culto y entre los mayas existe la creencia de que algún día podrá ser recuperada y la conexión se recuperará. De tal manera que se podrá volver a tener ese suministro de sangre y vitalidad divina a través de la cuerda que hará posible volver a tener comunicación entre los dioses y los seres humanos.

La vida cotidiana maya en todas sus formas estaba conectada a patrones complicados del transcurrir en el tiempo y el espacio. La creación se representaba no sólo en el mito, sino que se buscaba reproducir en cada uno de sus actos importantes y en el trazo de sus ciudades y casas. La sociedad maya tiene la labor de continuar centrando el mundo igual que lo hicieron los dioses primordiales. La comunicación entre los dioses y los individuos, es vital, pues para eso crearon los dioses a los seres humanos, para poder comunicarse con seres inteligentes.

${ }^{68}$ Barba, Beatriz. "Raíces de mitos mayas". En Historia de la Religión..., p. 21. 
La serpiente tiene un significado profundo en la concepción maya del mundo y de lo creado. La serpiente emplumada fue un dios importante en la iconografía maya. $\mathrm{Y}$ hoy, en los pueblos subsisten esas imágenes pero muchas veces están ligadas con algo no muy positivo, aunque existen las llamadas serpientes de visión, quienes dan a los aprendices de chamán el conocimiento especial que sólo algo sobrehumano puede transmitir. Existe una tradición yucateca en la que la mujer acaricia una serpiente cuando quiere aprender al bordar, porque le transmite una habilidad y conocimiento especial para desarrollar la labor.

El mito de la creación entre los mayas nos remite a un mundo en el que el ser humano sigue teniendo singular importancia, pues es el continuador de la creación de mundos y realidades y el responsable de continuar la comunicación entre el mundo material y el espiritual por medio de la consagración de sus acciones como parte de la continuidad del cosmos y del mundo que nos rodea.

El Dios del maíz es el que logra una serie de proezas que permiten a los mayas identificar su propia esencia. Las estaciones fueron definidas por él; venciendo a los ejércitos subterráneos, logra el compromiso de que cada año suban los rayos a la tierra para producir la lluvia. Resucita a su padre que simboliza la semilla-corazón que 
menciona López Austin y que es el maíz mismo, que es resucitado por el dios del maíz, su hijo.

El maíz es el alimento básico de los pueblos mesoamericanos y constituye además la esencia de su alma. Cuando muere, el ser humano recobra su esencia de semilla. Los humanos viven gracias al maíz y a la lluvia que hace crecer la semilla, han sido creados como seres cuyas necesidades han sido satisfechas por los dioses, pero a su vez, ellos tienen que satisfacer las apetencias divinas. Los humanos fueron los seres que tenían la inteligencia, la sabiduría y la voz para venerar a los dioses.

No se ha estudiado más que el uno por ciento de las ruinas mayas y de su mundo, y ya se comprende la magnitud de los logros hechos por esta cultura y se ha encontrado que la variación de muchos de cálculos astronómicos es de tan sólo unas décimas de los resultados contemporáneos obtenidos por la ciencia.

Debemos entender que el acercamiento a las culturas antiguas de las cuales todavía subsisten pobladores, se hace en nuestros días desde nuestro sitio en la civilización occidental, y debemos entonces intentar, aunque sabemos que es labor imposible, abrir nuestros ojos a esos mundos que vemos como exóticos, como otros y tratar de dejar a un lado la soberbia de sentirnos los observadores conocedores. 
Levi-Strauss entendió y nos explica de una manera muy bella y triste, el papel que jugamos al observar dichas culturas. El acercamiento a ellas se hace, como dice este autor, desde los remordimientos de la sociedad actual que ha luchado por anular la diversidad. ${ }^{69}$

Respecto al tejido, se han encontrado pocas muestras de los tejidos mesoamericanos, pues el clima no permite la conservación de las telas o hilos. Los pocos fragmentos que se han hallado, muestran tejidos complicados del Postclásico tardío. ${ }^{70}$ Las mejores muestras de lo que eran los textiles se pueden ver en las esculturas y las pinturas murales, así como también en la alfarería, donde aparecen las figuras lujosamente vestidas, con tejidos de una amplia diversidad en sus patrones.

69 Ver: Levi-Strauss, Claude. Tristes Trópicos.

70 Sharer J., Robert. Op cit., p. 686. 

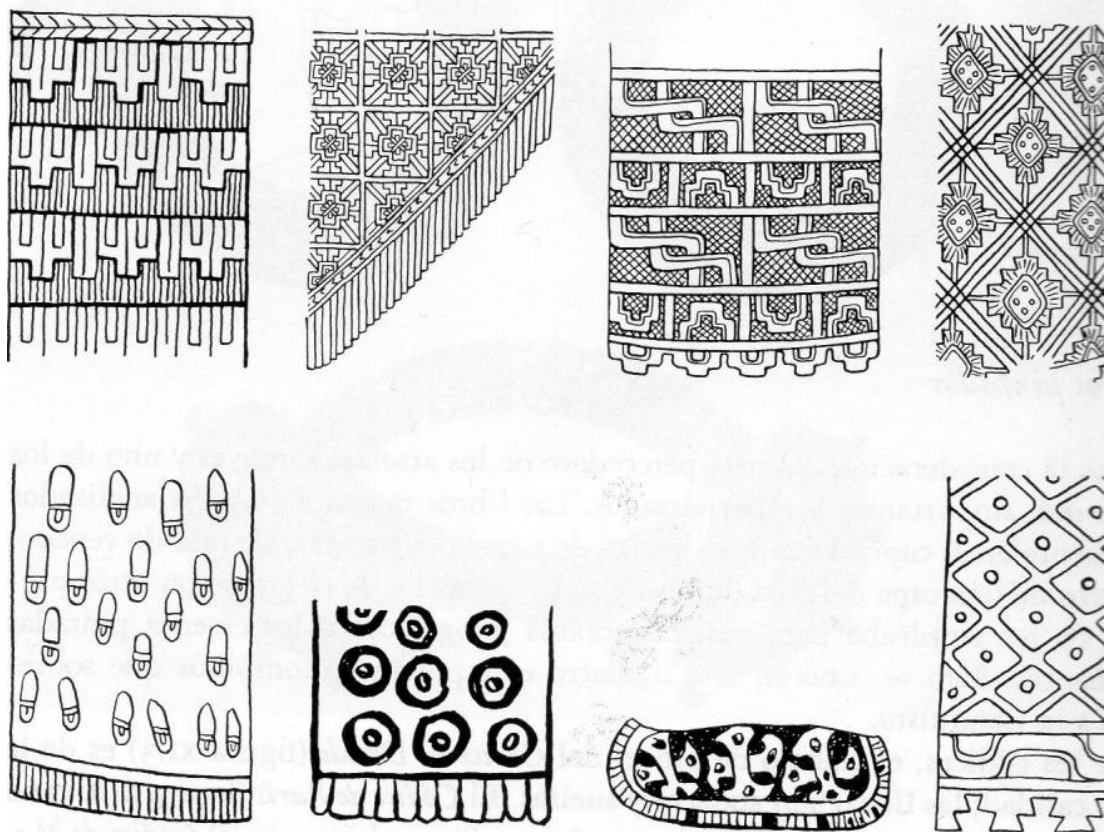

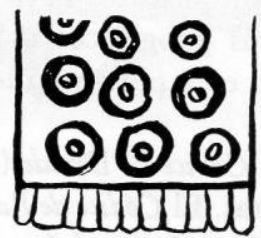

$f$

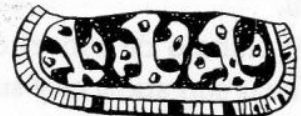

9

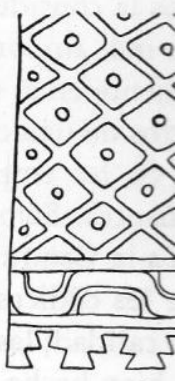

h

Textiles tomados de monumentos, murales y piezas de alfarería. ${ }^{71}$

La diosa Ix Chebel Yax aparece en el códice Madrid tejiendo en el telar de cintura con los implementos que se usan todavía en la actualidad en las comunidades mayas. El telar de cintura ha perdurado en el uso debido a los pocos requerimientos técnicos para construirlo y al gusto de las mujeres indígenas por el tejido. Como se vio anteriormente, sólo se necesitan algunos palos y el hilo para formar la estructura completa y se pueden elaborar ahí tejidos con técnicas sumamente complejas.

71 Id. p. 686. 
En las culturas mesoamericanas la mujer, la creación, el tejido, también son una triada inseparable. En las prendas se reproducían los símbolos que formaban parte de la sustentación de su mundo y del cosmos. La importancia de los mitos de la creación subsiste hasta la actualidad en los herederos de esta civilización y aunque modificados debido al paso del tiempo y al peso de culturas impuestas por la fuerza, perduran rasgos de los antiguos mitos.

Temprano en la época de la Colonia, el español López de Collogudo en su Historia de Yucatán, decía "Tenían fábulas muy perjudiciales de la creación del mundo, algunos, (después que supieron), las hicieron escribir, y guardaban, aún ya cristianos bautizados, y las leían en sus juntas", lo que demuestra que no fue fácil abandonar la estructura que había dado vida a la cultura maya. Aunque el análisis del Popol Vuh es un poco complicado porque los expertos ${ }^{72}$ consideran que tiene integrados mitos de diversos pueblos, para nuestro propósito pudimos tomar las líneas generales que nos interesan en la conducción de nuestro trabajo.

\footnotetext{
72 Barba, Beatriz. "Raíces de mitos mayas. En Historia de la Religión..., p. 55.
} 


\section{DIOSAS Y TEJEDORAS EN LAS CULTURAS MAYA Y}

\section{AZTECA}

En las religiones de que tratamos, los dioses eran patrones de las diversas actividades que se realizaban en la vida comunitaria de los pueblos. La concepción que tenían del mundo y de su funcionamiento involucraba tanto al humano como a las deidades que tenían una activa participación en el desarrollo de los acontecimientos.

El ser humano debía repetir los actos primigenios que fueron enseñados por los dioses, el humano mismo era un continuo creador en el nivel que habitaba y tenía una relación de intercambio con los dioses que habitaban el cielo y el inframundo. Repitiendo lo que los dioses habían realizado por primera vez en el universo, se aseguraba el mantenimiento de los modelos primordiales y había además que alimentar a esos dioses que pedían retribución. La realidad habitada y vivida por el ser humano no era independiente o alejada del mundo divino, había una conexión continua y los intercambios sucedían con regularidad para asegurar la actividad en ambos planos.

Los distintos oficios eran enseñados por los dioses como actividades tendientes a mantener el equilibrio de la 
sociedad y del cosmos, pues emulaban actividades que los dioses realizaban en su propio espacio-tiempo. Cada artesano sabía que los fundamentos de su actividad descansaban en un modelo divino y las técnicas, tanto como los objetos utilizados para desarrollar el oficio tenían un carácter sagrado. Por esto, los individuos que se dedicaban a cierto oficio tenían una serie de rituales y dioses patronos muy bien definidos.

El tejido estaba entre las actividades que tenían carácter de oficio, ya que de ahí surgía la ropa cotidiana para la familia y también las prendas y trajes que usaban las distintas clases sociales, además de los trajes ceremoniales que eran parte importantísima en la parte del culto por todo el simbolismo y jerarquía que debían comunicar.

En Mesoamérica, el vestuario hablaba de la dignidad de la persona $y$ las diferentes prendas o tocados eran diseñados con los atributos que pertenecían a cada dios en particular. Hay un ejemplo muy claro cuando se nombra a la diosa Coatlicue como la de la falda se serpientes, o cuando vemos las figurillas de cerámica o los murales en donde se plasman las imágenes de los lujosos y elaborados trajes o tejidos que se utilizaban en ese tiempo.

A las mujeres cuando nacían se les ponía cerca un huso y madejas de hilo para motivar una dedicación constante y 
minuciosa al tejido, pues a lo largo de su vida estaría siempre presente. De hecho, los estudiosos han sabido que pequeñas mantas de algodón se utilizaron como moneda rudimentaria y todo el tejido estaba en manos de mujeres.

La producción masiva de dichas prendas se puede imaginar por las referencias que tenemos de tiempos tempranos de la colonia, o incluso por los códices en donde los números de textiles que se utilizaban como tributo de un pueblo a otro eran muy altos. De hecho se puede deducir por dichas cantidades la importancia social y económica que tenían las mujeres productoras de tejidos. Y eso sin mencionar todo el vestuario para el culto que tenía horas y horas de trabajo con las telas y los materiales preciosos que llevaban para su lucimiento.

Las tejedoras más preciadas, que generalmente eran las expertas ancianas, tejían las prendas para ciertas ceremonias importantes y además se les permitía tener un papel activo en dichas ceremonias.

Como se comentó anteriormente, en el mundo divino, el elemento femenino tenía igual importancia que el masculino, las diosas jugaban un papel preponderante por la existencia del culto a la fertilidad. Lo femenino era valorado por su capacidad de dar a luz. Y los atributos de las diosas tenían que ver con el surgimiento de nueva vida. Las diosas de la fertilidad también eran las diosas 
del tejido y se asociaba a éste directamente con la fertilidad, y ambas son cuestiones propiamente femeninas.

El culto relacionado con la lluvia era uno de los más importantes en la cultura mesoamericana, pues regulaba los ciclos de la agricultura y por lo tanto del sustento del pueblo. Asimismo se relacionaba el tejido con la lluvia pues los hilos de la urdimbre representaban la lluvia e incluso en algunos lugares al palo que apretaba la trama se le introducían semillas para que al pegarle contra los hilos hiciera el sonido de la lluvia, de hecho todavía en nuestros días se nombra así, "palo de lluvia", a un instrumento musical que produce un sonido como de correr de agua.

La trama era la tierra de la que surgían nuevas formas y colores; tal como las montañas eran los depósitos de las riquezas del mundo, así la trama se convertía en una tela que tenía rico colorido y era plena de significado. El eje del que se amarraba el telar, era uno de los árboles que conformaban el mundo y se hacía con él la conexión con los diversos niveles del cosmos para que el tejido se viera beneficiado por las corrientes de las fuerzas creadoras.

Una de las diosas con esa relación perteneciente a la cultura azteca era Xochiquétzal, Era la diosa de la belleza, de la sexualidad, y patrona de los artesanos y las mujeres preñadas, estaba ligada con la luna y se consideraba 
consorte del dios de la lluvia. Ella inventó el tejido y el hilado.

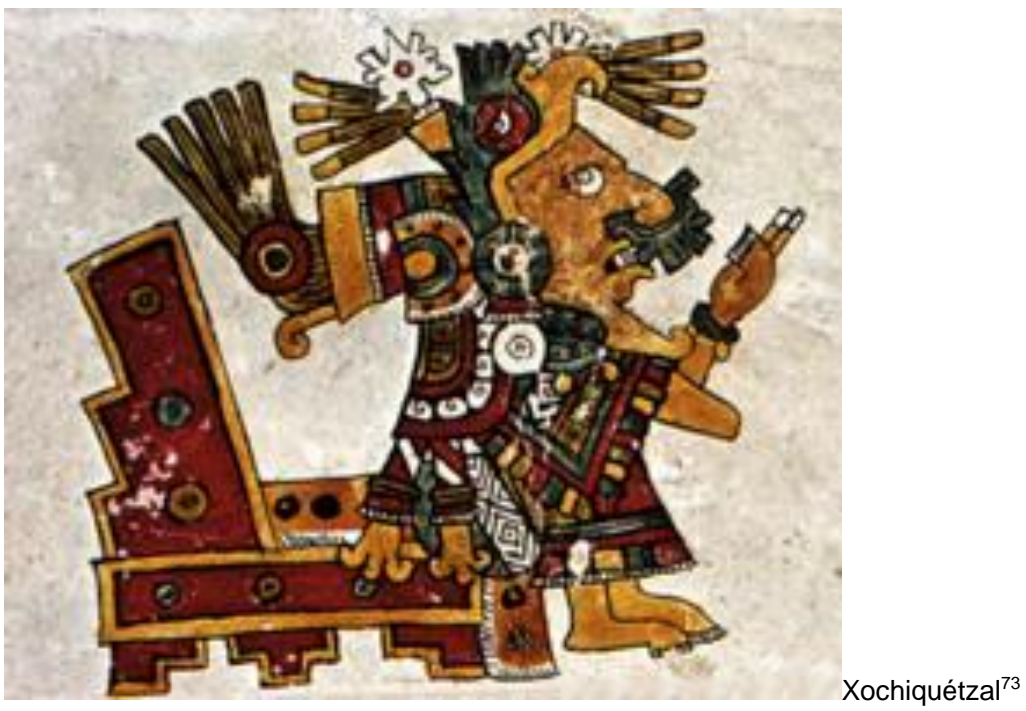

Se representa a la diosa con un atavío que integra el algodón y otros implementos que se usan para tejer. Su festival se hacía cada ocho años y en el ritual que se hacía, cuenta el cronista Durán, una mujer se vestía ricamente y representaba a la diosa, tejía y realizaba algunas otras actividades antes de ser sacrificada. Se le quitaba la piel y el sacerdote se la ponía encima para personificar ahora él a la diosa, en un ritual de renovación,

73 mexicolore.co.uk 
tal como las serpientes dejan su piel para tener una nueva cubierta.

A pesar de lo cruento que parezca, los sacrificios estaban justificados en la visión mesoamericana porque eran una manera de alimentar a los dioses y de asegurar la existencia del mundo como se conocía. Además, se supone que los sacrificados normalmente iban seguros del honor y el lugar que les tocaría en el cielo junto a los dioses y con una existencia más allá del dolor y las penalidades de esta tierra.

Los expertos han encontrado que los mesoamericanos relacionaban la fertilidad, la lluvia, la serpiente, lo femenino, y el tejido, como parte de una realidad que no se limitaba a la cuestión ritual, sino que se extendía a todas las formas que tuvieran relación cotidiana con los aspectos anteriormente mencionados.

Otra diosa relacionada con el tejido era Tlazoltéotl, a quien también se llamaba Tozi o Teteo Innan, la madre de los dioses. ${ }^{74}$

74 Thompson, Eric. Historia y religión de los mayas, p. 301. 


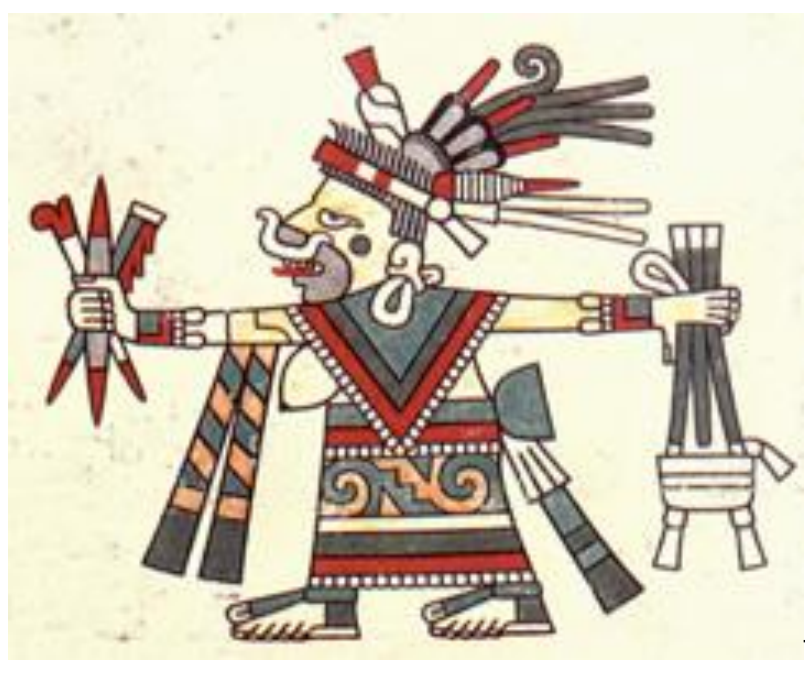

Tlazoltéotl

Representa la mujer en la etapa madura de su vida, la que tiene la experiencia y es la que lleva más indicadores de su relación con el tejido, por ser una actividad que se perfecciona con el paso del tiempo. Tiene en sus manos instrumentos de tejido y en su tocado lleva madejas de hilo así como las varas usadas en el telar de cintura. Era la diosa de la luna, y patrona de la medicina, las prostitutas y del alumbramiento. En el códice Florentino aparece con su tocado el cual tiene husos, que en las creencias de los mayas contemporáneos se cree que le servirán para defenderse cuando los jaguares del inframundo la ataquen una vez que este ciclo de existencia termine.

Estas diosas son las representantes de todo lo femenino y lo que a ello está relacionado. Su culto abarca un campo muy extenso, pues la fertilidad, al ser el concepto más 
importante, se relaciona con la tierra y sus frutos, la tierra guarda las semillas y de manera misteriosa hace que renazcan, tal como aparece un nuevo ser humano tras nueves meses que pasa oculto en el seno de su madre.

El cordón umbilical también es una figura importante y por analogía, es una representación de la serpiente, tal como lo son también los ríos, el viento en su movimiento, la lluvia, el cabello, las venas que llevan el precioso líquido que alimenta a los dioses, el hilo que da vida a una tela, la cuerda que sostiene el telar al árbol que representa el eje del mundo y por el que se lleva a cabo la comunicación con los dioses, etc.

Como podemos ver, el mundo entero, con cualquier cosa que nos pudiera parecer insignificante, tenía un profundo contenido divino que integraba todo lo existente con unos pocos conceptos místicos.

Para los mayas, la diosa del tejido también es una deidad lunar, y la luna es esposa del sol y la primera mujer que tejía cuando el sol se fijó en ella. La diosa en cuestión se llama Ix Chebel Yax, esposa del creador quien es representada con una madeja de hilo o un huso con algodón. 


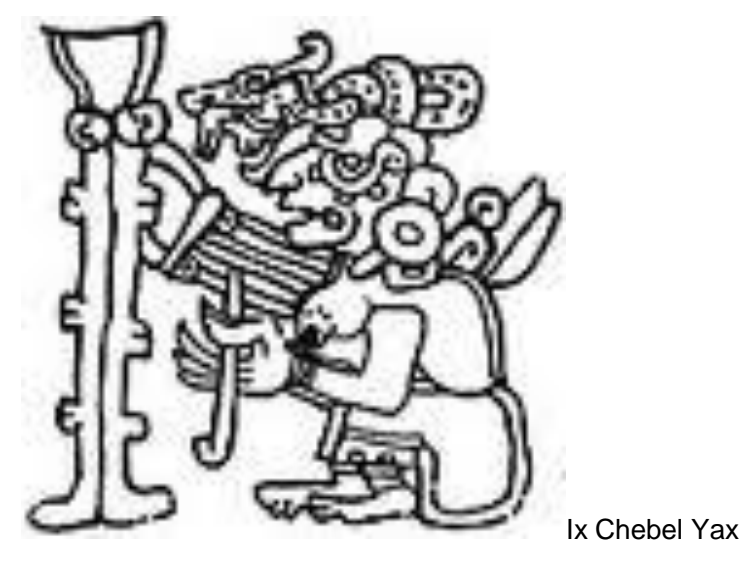

En esta representación, la diosa es mostrada tejiendo en el telar de cintura que está sujeto al eje del centro del mundo. Sostiene en su mano uno de los separadores para abrir la urdimbre y poder introducir los hilos de la trama.

En las concepciones más antiguas se refiere también que la diosa primordial la diosa $\mathrm{O}$, llamada también Ixchel, era también patrona del tejido, y esto no se contrapone, pues la diosa tejía el mundo y por otro lado, dicha actividad era de las más importantes para las mujeres; además, la actividad completa del tejer comprendía muchos pasos y procesos que fácilmente podían ser compartidos por ambas diosas. 


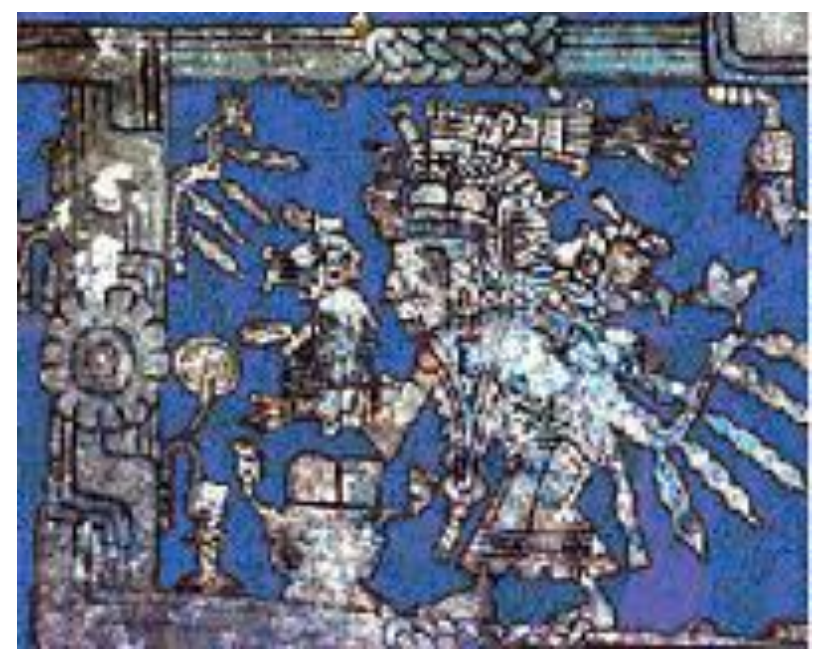

Una representación de Ixchel

La diosa Ixchel era la patrona del parto y se relacionaba con las arañas debido a que éstas tejían su tela así como las mujeres las telas para vestirse, tal como les enseñó la diosa. Era la esposa del dios del cielo y tenía influencia sobre la lluvia, por lo que algunas veces se le representa sacando agua de una jícara. Era la diosa de la luna por la relación que ésta tenía en el movimiento de las aguas y los ciclos lunares del embarazo y la menstruación que afectaban a las mujeres.

Estas dos deidades estaban relacionadas con los lagos y el agua subterránea que daba origen a los cenotes, tan importantes para los mayas, tanto para rituales como para obtener agua y por considerarlos un conducto de comunicación con el inframundo, por lo que dichos cenotes eran sagrados. 
Posteriormente, y como producto de la colonización, los frailes hicieron una equivalencia de los dioses prehispánicos con los dioses cristianos para facilitar la evangelización, lo que llevó a confusiones que perduraron a lo largo del tiempo. Los especialistas recién están corrigiendo ciertas cosas basados en estudios más completos acerca de la totalidad de la realidad maya y sobre todo con el avance que se ha tenido en el desciframiento de los glifos y los nuevos hallazgos arqueológicos, además del estudio comparado de los códices y escritos que están en bibliotecas y archivos.

En varios textos se menciona a las diosas tejedoras nombrando también varios instrumentos que representaban o se utilizaban en su actividad sobre los hilos; por ejemplo se habla del algodón bruto, del hilo hilado así como del teñido que era importante por la relación simbólica que tenían los colores, la barra de tejer, el malacate para hilar y otros instrumentos ligados a la actividad.

En el Ritual de los Bacabs se cita a una diosa llamada Ix Hun Tah Dzíb y a otra llamada Ex Hun Tah Nok, cuyos nombres para Thompson quieren decir "Señora Única Dueña del Pincel" y "Señora Única Dueña de la Tela", mostrando que realmente son personificaciones de la antigua diosa "O", diosa creadora primordial en cuyo glifo 
siempre se encuentra un rollo de algodón y una madeja de hilo. ${ }^{75}$

Esta diosa Ix Chebel Yax era la diosa de la pintura, el brocado y el tejido y estaba asociada a la luna y al color rojo. La luna era un símbolo muy importante para las culturas mesoamericanas, por su relación con los ciclos de siembra y su efecto sobre el agua. La luna, para los mayas también tenía que ver con el parto, la preñez, la medicina, con todo tipo de agua contenida y se sospecha que en la religión original, también era la diosa de la tierra y sus productos.

También el culto de estas diosas del tejido está relacionado con la sexualidad, tanto en su manifestación meramente carnal como para la reproducción. El acto sexual era un acto sagrado en cuanto repetía la cohabitación de los primeros dioses para dar vida a los demás. Pero también se consideraba el sexo como mera fuente de placer, aunque su práctica en la sociedad prehispánica estaba reglamentada.

Existen estudios sobre las sociedades prehispánicas que demuestran que la sexualidad era vista como algo natural y no había tantas restricciones como las que tenemos hoy

75 Thompson S., J. Erick. Historia y Religión de los mayas, pp. 256257. 
en día y no se diga como las que se tenían en Europa en el tiempo de la Conquista. ${ }^{76}$

La civilización maya ha sido profusamente estudiada y el contacto que los expertos han tenido con los diferentes grupos de indígenas mayas actuales, ha permitido el esclarecimiento de muchas de las creencia antiguas así como también un rápido avance en el desciframiento de la escritura maya y de los glifos que se han encontrado, por lo que se espera hallar muchas pistas sobre los vestigios que aún permanecen sin descifrar.

Los rituales mayas contemporáneos aún contienen algo de ese contenido místico y mágico, de repetición del rito primordial, y aunque en algunos aspectos el paso del tiempo y las influencias culturales que han cambiado la vida de los pueblos mayas ha hecho que se pierda en alguna medida el significado profundo, los investigadores están logrando seguir los hilos que tejen toda la historia de esa civilización tan rica y compleja.

En algunos estudios acerca de los mitos de los grupos mayas contemporáneos, existen reminiscencias de las antiguas diosas. En un grupo de mayas tzetzales, se puede ver la relación del tejido con la creación en uno de sus relatos: un muchacho vio que una anciana estaba

\footnotetext{
${ }^{76}$ Ver por ejemplo la tesis de Mauro Arnold Montejo Díaz. La sexualidad maya y sus diferentes manifestaciones. 2012. O los estudios que sobre las representaciones ligadas a la sexualidad que dejaron los incas de Perú.
} 
hilando algodón y tomó unas de las semillas que habían salido de la carda y corrió al bosque y las lanzó a un árbol, creando así las abejas que dan la miel. Aquí se ve claramente la relación de la diosa vieja con el hilado y cómo desde la actividad de tejer surge la posibilidad de crear nuevas cosas para el bienestar de los seres humanos.

En otro relato de los mayas mixes, una anciana está arreglando su telar para tejer y de repente aparece un colibrí, ella lo guarda en su seno y queda embarazada. ${ }^{77}$ El tejido muestra aquí la misma relación de los antiguos mitos donde el sol se fijó en la luna mientras tejía. De nuevo el tejido es fuente de nueva vida, posibilidad de creación. Y es interesante ver estas actividades de la luna porque en el Período Clásico ya hay evidencia de ellas.

Las mujeres mayas de la antigüedad dedicaban su tiempo a las labores del hogar y los hijos, además de ayudar en el campo y con muchos otros trabajos. Pero el tiempo dedicado a tejer, era un tiempo que se apartaba de la concepción normal, Cuando se iba a tejer, se hacía el ofrecimiento del tejido, y la mujer se ponía en posición para imitar la creación.

Los hilos de henequén eran remojados en un líquido hecho a partir del maíz para que tuvieran mayor resistencia y era entonces de esa manera que el alimento

77 Thompson. E. Historia..., pp. 428 y ss. 
de los seres humanos alimentaba también el hilo para que pudiera formar parte del proceso de creación. Los hilos se identificaban con la lluvia y también con el cabello, el cual se peinaba para ordenarlo y asimismo los hilos se ordenaban con el peine para crear ese orden primordial que permitiría el surgimiento de algo nuevo. ${ }^{78}$

Hay investigadores que han encontrado que las tejedoras mayas les dicen que el movimiento que la mujer hace al tejer simula el movimiento de las contracciones al momento de dar a luz y que el movimiento que se hace cuando se bajan los hilos de la trama recuerda al movimiento que existe durante el acto sexual. Además, la historia de una princesa o diosa que queda preñada mientras barre 0 teje, existe en varias culturas mesoamericanas. La iconografía en los códices, muestra un ave, que generalmente cuando se trata del acto de tejer es un colibrí y está parado sobre los hilos o el telar, él es el que preña a la mujer, quien tendrá hijos que serán héroes.

Cuando en ciertos lugares las mujeres se refieren al acto de agregar la trama, le llaman "sembrar" los hilos y sembrando los hilos surge la tela que contiene los elementos simbólicos, sobre todo en los vestidos ceremoniales, que representan su concepción del mundo.

\footnotetext{
${ }^{78}$ Ventura, Carol. Mayan hair hashes..., p. 12.
} 
La preparación para tejer también requiere en algunos casos, - como el de la elaboración de una prenda para alguna ceremonia importante o la invención de un nuevo diseño-, de ritos y ofrecimientos que sirven para tener éxito en la empresa y obtener inspiración que hará que el tejido salga perfecto.

Todo esto es importante porque relaciona el tejido con la fertilidad y con las diferentes fuerzas que mantienen funcionando el mundo, tales como el agua o el viento, incluso el fuego de los volcanes, y mantienen funcionando la vida humana al dar lugar a nuevos seres para preservar la existencia de la raza. En las culturas mesoamericanas se creía en la estrecha vinculación del macrocosmos y el microcosmos. ${ }^{79}$

La función de la mujer como tejedora, creadora y dadora de vida, la colocaba en una situación de suma importancia en la sociedad mesoamericana, pero con la conquista, se diluyó ese estatus. El establecimiento repentino de otro esquema en la sociedad ocasionó que la mujer descendiera en posición respecto del hombre y dentro de la sociedad.

El esquema europeo llegó con el predominio total del hombre y la subordinación de lo femenino al interior de la casa y a las limitaciones que la rígida nueva sociedad imponía. Las mujeres quedaron más recluidas al interior

79 Güemez Pineda, Manuel La construcción... 2000. p. 314. 
de sus casas y a las labores que podían ejercer en el espacio doméstico. Esta represión se puede ver en algunas medidas que se tomaron justo cuando llegaron los conquistadores, tales como exigir que no se bañaran tantas veces y que se cubrieran el torso y los brazos por considerarlo inmoral, por lo que incluso debieron cambiar su vestimenta.

La introducción de los telares mecánicos de pedales y la demanda de más telas para vestir a los recién llegados, así como la introducción de los oficios que se tenían en España, hizo que los hombres comenzaran a tejer. Pero es en ese punto en que el tejido comenzó a perder su contenido simbólico y la relación con una actividad divina para convertirse en una actividad industrializada, fría y sujeta solamente a la demanda del producto. Los indígenas aprendieron pronto el oficio y dominaron las técnicas traídas del Viejo Mundo.

Pero no todo estaba perdido; dentro de sus hogares, las mujeres siguieron con su tejido en el telar de cintura y se puede suponer que siguieron siendo las depositarias del antiguo sentido simbólico de dicha actividad. Ellas continuaron trabajando a la manera perteneciente a su propia cultura y es por eso que todavía es posible en la actualidad encontrar en las comunidades indígenas el tejido con el antiguo telar de cintura, pues fueron las continuadoras del antiguo y respetado oficio de tejer. 
Por otro lado, los obrajes, que eran los centros de trabajo en los que se instalaron los telares para la producción textil en la Nueva España, concentraron una gran cantidad de hombres dedicados a la actividad. Su historia es motivo de investigación para muchos estudiosos pues es muy interesante el haber pasado de ser lugares donde se aprendía y desarrollaba el oficio, a verdaderos centros de explotación y castigo, pero no es tema para mostrar aquí.

Al observar los conceptos de estas culturas precolombinas, nos damos cuenta de las profundas relaciones que existen entre sectores que en la actualidad hemos separado por completo. Una visión integral del mundo les permitía entender mejor a la naturaleza y actuar conforme a su conservación, no en contra de ella. Hay mucho que aprender de estas formas de ver el mundo, de esa integración que conforma una unidad que hemos perdido. Creo que hoy, a través del arte estamos recuperando esa conjunción integral de planos tan diversos. La creación, las mujeres, el tejido y el arte tienen una relación profunda desde tiempos remotos y hoy nos toca hacer aquí un acercamiento a esos sectores que nos son tan familiares y a la vez tan enigmáticos. 


\section{La mujer y el tejido}

La sujeción de la mujer al hogar, proviene, a mi parecer, de la maternidad y el cuidado de los hijos. Al tener que cuidar al recién nacido, se limita la acción fuera de la casa y esto trajo como consecuencia natural que los quehaceres domésticos fueran los más cercanos a la mujer. Poco a poco se fue dando la construcción social de la identidad de género. La servidumbre por la maternidad es cultural, no individual; se construyó poco a poco el arquetipo de la madre abnegada y sumisa que da todo porque los suyos estén bien.

Se ha comprobado que las madres dentro de la sociedad primitiva no podían permitirse estar siempre en el mismo lugar y tenían que colaborar para encontrar comida, siempre con su niño cargado. Aunque cuando se dedicaron a la agricultura, tuvieron más tiempo y es entonces que surgió la comparación de la mujer con la tierra, la idea de la fertilidad y en ese tiempo el respeto por lo femenino como creadora de nuevos seres humanos ${ }^{80}$.

\footnotetext{
80 Nuria Sorli en, Mauro Arnold Montejo Díaz. La sexualidad maya y sus diferentes manifestaciones, p. 54.
} 
La sociedad fue evolucionando y comenzaron a surgir ciertos patrones de conducta que llevaron a considerar a la mujer como alguien siempre al lado del hombre, y conforme fue avanzando el tiempo, cada vez más abajo del hombre.

Las actividades hogareñas se hicieron dominio de la mujer y el tejido era una de ellas, aunque en muchas sociedades antiguas tenía especial importancia por su relación mítica con el origen del cosmos y la construcción del mundo; se consideraba una actividad sagrada por emular la capacidad femenina de preparar el mundo donde habitarían los seres humanos, al "tejer" las relaciones entre los elementos y la tierra así como los destinos humanos.

El mito preserva tradiciones, sobre todo en cuanto a lo femenino se refiere. La sociedad patriarcal deja de lado muchas cosas que les importan a las mujeres, pero ellas han encontrado la manera de conservarlas en las actividades que realizan, tal vez en forma de leyendas, de historias que les cuentan a sus hijos, de dichos y expresiones que pasan de una generación a otra.

El tejido y la costura son dos actividades que han servido para la expresión de la sensibilidad femenina durante toda la historia. En ellas se han vertido largas horas de trabajo, expresión, frustración, emociones, obligaciones, 
sometimientos, liberaciones, etc., que las mujeres han vivido en su época y entorno.

El tejido es un campo complejo: su significado y las metáforas que puede representar cubren muchos de los actos y situaciones humanas. Unión de los contrarios en un resultado final mejorado, los hilos horizontales se unen con los verticales en el cruzamiento de las fuerzas movidas por el tejedor y avanzando hacia una nueva realidad.

Cuando la tejedora corta el textil, separándolo del telar, corta el cordón umbilical que une el producto a su creadora, libera una nueva existencia, una nueva vida que significará por sí misma. El tapiz, la obra de la fibra, existirá por él mismo con su propio significado y con los contenidos que la tejedora ha puesto en él.

La aguja, herramienta del coser y del tejer, es herramienta importante, puede unir pero a la vez puede herir a quien la manipula $o$ a quien se dirige con tal fin. Es el material rígido que transporta al hilo, que lo lleva a unirse con sus iguales, que lo guía para la construcción de algo mayor, o para tapar huecos con el hilo.

El bordado o cosido sobre la tela le proporciona riqueza, le da cuerpo y la provee de una nueva presencia a la vez que puede ser restaurada por el hilo. La tela es el soporte y el alma que están ahí para que con ella se construyan nuevos planos de existencia. 
La mujer dota de un sentido distinto a la actividad con la aguja y el tejido. Como representa en muchos puntos de la historia una dominación, un aislamiento, una segregación de las actividades masculinas, una pertenencia al hogar que a veces no era deseada, un medio por el que la mujer debió encontrar su propio cauce de expresión, el trabajo con las fibras e hilos pudo encontrar un hueco en las manifestaciones artísticas por el cual pudo obtener otro estatus; desde el punto de vista femenino se necesitaba despojar al tejido y a la costura de la carga con que las sociedades lo habían anulado para llevarlo a una expresión auténtica y perteneciente, lo que se aprovechó totalmente.

El vestido como coraza protectora, como la representación de lo que queremos que el mundo vea, como la inserción de nuestra persona en el campo visual de los otros, como pertenencia, deseada o no, a un estrato humano, como protector de nuestra fragilidad y nuestra vulnerabilidad, como símbolo psicológico, como cómplice de los secretos y defectos más íntimos y como auxiliar en su disimulo, como vehículo que nos permite aparentar varias personalidades, el vestido, decíamos, nos acompaña y remedia la desnudez que en todo lo largo de la vida tratamos de cubrir ante los demás y a veces ante nosotros mismos. 
La introspección que implica la costura y el tejido, permite que la fuerza de quien teje se sintonice con las fuerzas que contienen los hilos al manejar la capacidad expresiva del color, de la textura, de la imagen que obtiene al unirse con otros hilos. Permite que quien lo ejecuta se concentre en la exactitud que debe seguir la técnica, cada hilo debe ir en su propio lugar, jugar su papel exacto en la construcción de la tela. Permite que se sintonice con la observación del cosmos que le provee inspiración y le da material de imaginación visual con el que podrá moldear lo que quiere decir. Permite al individuo empaparse con las energías y propiedades de cada uno de los materiales usados para descubrir sus capacidades. Permite hacer la relación con lo psicológico, consciente e inconsciente, con el actuar desde la individualidad hacia el mundo, con la magnificencia de engendrar algo nuevo, con el ejercicio de la voluntad y la imaginación, y sobre todo, con el encuentro con ese lado íntimo que aflora e invade a quien está tejiendo.

El textil y las fibras que anteriormente se pensaba que pertenecían a otros ámbitos fuera del arte, trabajan actualmente con muchos materiales que están en este tiempo desprendiéndose de sus ataduras de significación inmediata, de su interpretación sujeta a oficios y condiciones tales como las de género, lo doméstico, lo marginal. 
El discurso feminista en todas sus variantes ha apoyado la recuperación de dichos ámbitos y su aceptación en los niveles que se encuentran dentro del arte. La apertura del universo artístico acoge los nuevos significados que se le dan a sectores que nos pudieran parecer tan fríos como la tecnología o tan constreñidos como las tareas domésticas y los artistas han logrado proponer nuevos nichos de creatividad incorporando técnicas y materiales antes considerados menores para el arte.

\section{LAS MUJERES}

El surgimiento del feminismo y su desarrollo en diversas posturas, ha propiciado un sinnúmero de relaciones y conexiones entre las áreas en las que las mujeres se mueven dentro de la sociedad contemporánea. La presencia femenina ha crecido en sectores antes reservados únicamente para los varones.

En el arte mismo, la presencia femenina es más influyente que nunca antes a pesar de que muchos autores consideren aún en nuestros días, sobre todo en las altas esferas de artistas consagrados, que el verdadero talento pertenece únicamente al género masculino. Las mujeres abordan con gran fluidez, sobre todo en el arte de la fibra, la creación de nuevas propuestas y el desarrollo de 
nuevos parámetros dentro de los que se incluyen actividades que antes pertenecían exclusivamente a las mujeres y su casa.

La construcción de un arte femenino-feminista tiene que integrar lo que somos ahora las mujeres y lo que se es como mujer individualmente. Es la unión del propio ser con el contenido histórico de la parte femenina. No yendo hacia la apropiación de las parcelas machistas y sus maneras, sino ubicándose un escalón más arriba, desde donde se pueda ver la totalidad del paisaje de los géneros y sus relaciones

Está sobre la mesa la pregunta de si existe la posibilidad de postular un feminismo personal donde sea posible barrer tabúes, quitar complejos y desarrollarse de manera abierta e integral, no en la dinámica de la confrontación, sino en la de la relación personal consciente e igualitaria con el hombre.

Es necesario ver a la mujer como un elemento de cambio, creación y evolución, y no porque se esté en contra de los hombres, sino porque, como la sociedad ha sido creada por lo masculino como lo dominante, ahora el elemento femenino debe poder construir desde su propia visión un mundo distinto, incluyente, que abarque ambos géneros como complementarios, como fuerzas que necesariamente tienen que encontrarse y encontrar en sus diferencias la motivación para componer el mundo. 
Aunque el feminismo es un movimiento que ha logrado muchas maneras de que las mujeres adquieran relevancia, algunas veces se supedita lo femenino a un patrón distinto al masculino, pero finalmente sigue supeditado, ahora a un patrón construido por mujeres.

En estos tiempos se puede tener la libertad en el trabajo y la convivencia, en la tolerancia y la interioridad, y se puede confiar más en la integración que en la escisión. Sin rencores pero tampoco con miedos. Sin inferioridad, sino con todo el empuje para el avance. Aprendiendo de la historia pero con toda la energía dirigida al futuro. En el reconocimiento de que la mujer posee ambos géneros dentro de ella como construcciones naturales y sociales y a los que se puede recurrir cuando se entra a los territorios de la expresión artística, pero en la afirmación de la condición plena de mujer en el toque final de la obra. 


\section{CAPÍTULO 2. ORIGEN Y CREACIÓN. \\ EL TEJIDO COMO ACTIVIDAD PRIMIGENIA}

\subsection{DOS CAUCES DE LO ORIGINARIO}

En el capítulo anterior vimos cómo los humanos pertenecientes a las civilizaciones mesoamericanas concebían el origen y cómo daban respuesta a las preguntas acerca de él por medio de los mitos que estaban estructurados de acuerdo a la ideología y conocimiento que poseían en ese momento. Juntando lo que sabían, —datos obtenidos por la mera observación de la naturaleza-, con las explicaciones que podían construir alrededor de ello, —producto de la estructura social y sus relaciones-, daban vida a una cosmología que integraba todo lo que eran como individuos y su relación con los dioses que habían formado el universo.

Su concepción del origen abarcaba el nacimiento de planetas, estrellas, la tierra, los diferentes niveles del cielo y el inframundo, todos los animales y plantas, así como el ser humano y todas las actividades que tenía que realizar durante su vida. Era una concepción que integraba al 
humano como elemento activo en la conservación del mundo.

Ese primer cauce de lo originario nos llevó a recorrer un mundo donde la magia tenía cabida, donde los conocimientos matemáticos caminaban lado a lado con la imaginación de seres mitológicos y con metáforas elaboradas para que todos los pudieran comprender $\mathrm{e}$ identificar con algo cercano y cotidiano. El movimiento de los planetas se mostraba con exactitud pero siempre ligado a las figuras míticas y su acción para la conservación del orden cósmico.

Las personas que realizaban los oficios o cualquier trabajo en el seno de la sociedad en que vivían tenían su correspondiente entidad sagrada, la divinidad que había mostrado el camino y las técnicas para lograr los productos. En el universo mítico podemos encontrar el espíritu y el conocimiento humano satisfaciendo integralmente la necesidad del ser humano por conocer y por imaginar, por explicarse el universo, y por no sentirse indefenso ante semejante inmensidad. Construyendo una figura que se identificara con los humanos, podían sentir que algo de control se ejercía en el cosmos.

El asombro ante el mundo es lo que motiva a la humanidad a buscar explicaciones del universo en que se mueve, y este asombro ha perdurado desde que el ser humano apareció sobre la tierra. Tanto los mitos como las 
teorías científicas acerca del origen responden a esa motivación para construir una respuesta. Desde diferente perspectiva abordan los mismos temas que se ha planteado el individuo para explicar su existencia en el cosmos.

Los mitos tienen generalmente un contenido religioso, se cree en una fuerza poderosa que conforma lo sagrado y que ha dado como resultado el universo entero. La ciencia, por su parte responde a experimentos que se han probado y que demuestran que lo dicho es cierto. Pero aún si sucede, como en la física contemporánea, que se tienen que comprobar muchas cosas, se espera de la ciencia que siempre responda con una comprobación.

La atracción hacia lo desconocido mueve la curiosidad humana y formula respuestas para tener cierto grado de control. ¿Cuál sería entonces la función social del mito y de la ciencia? Somos producto de nuestra sociedad y como individuos respondemos a las estructuras que definen el modo de ser de esta época.

El mito, -existente en la actualidad en las perspectivas religiosas que satisfacen a un buen número de gente-, ha dejado de tener cabida como la respuesta única y total a los interrogantes en nuestras sociedades contemporáneas, donde la ciencia ha sentado sus reales. Perdura esa concepción mítica en las explicaciones religiosas, pero en general, la estructura de la civilización 
contemporánea descansa sobre los datos duros que la investigación científica ha generado. Sin embargo, la mayoría de la gente tiene alguna creencia religiosa o mítica aunque acepte la ciencia como explicación cierta del mundo.

Esto pareciera una contradicción, pero en algunos casos, los dirigentes de las diversas religiones procuran hacer coincidir los actos de dios con los resultados de la ciencia para obtener mayor credibilidad, mientras que en otras religiones, la doctrina no acepta los avances científicos y cierra totalmente la posibilidad de aceptar otra cosa que no sea el dogma. La realidad religiosa en la actualidad es un asunto muy complejo, pero existe y determina los actos de mucha gente.

Desde la perspectiva científica buscamos respuesta a las interrogantes acerca de cuál es la causa por la cual existimos en este planeta en particular y cómo nuestro planeta se ubica en relación a todo lo que existe en el universo. También queremos saber cómo surgió la vida y por qué precisamente en la tierra; cómo surgió el primer humano; cómo llegamos a ser lo que ahora somos y cómo llegamos a estar como ahora estamos.

Todas las culturas que han existido han buscado respuesta a la interrogante del origen, y se han hecho profundos y numerosos estudios sobre el tema; una mirada sobre esas sociedades nos deja ver la riqueza 
expresiva, de imaginación y de investigación que ha surgido del cerebro humano a lo largo de las épocas. ${ }^{81}$

Las metáforas han sido el vehículo para expresar dichas explicaciones, tanto entre los antiguos sacerdotes que creaban un mito, como entre los ateos, creyentes 0 científicos que pretenden explicar sus complicados cálculos a los neófitos. Las imágenes nos permiten un mayor acercamiento a los fenómenos que los estudiosos tratan de explicar: sea la vía láctea como una barca que se hunde a lo largo de la noche, o la gran explosión del Big Bang, o el huevo cósmico, todo va dirigido a que el neófito pueda integrar a sí mismo la respuesta elegida.

Y la misma pasión existe tanto en los individuos que concebían el universo como producto de la actividad de los dioses, como en los individuos que ahora llamamos científicos y a los cuales usualmente vemos como fríos y calculadores sin pensar que comparten con aquellos otros, la fascinación por el universo y sus misterios. Se busca igualmente un mayor conocimiento de la verdad y un mayor conocimiento del interior del ser humano. En ese sentido religión, arte y ciencia se acercan, pues responden a una pulsión humana para encontrar el sentido de las cosas con lo que creemos es la verdad. Podemos mencionar lo que dice Marcelo Gleiser

\footnotetext{
81 Se puede ver una lista de los mitos del origen en las distintas civilizaciones en: http://listas.20minutos.es/lista/los-mitos-de-lacreacion-del-mundo-342077/
} 
"Hay mucho más en la física que sólo resolver ecuaciones e interpretar datos. Me atrevería a decir que hay poesía en la física, que la física es una expresión profundamente humana de nuestra reverencia hacia la belleza de la naturaleza." ${ }^{2}$

Las respuestas que se han dado a lo largo de la evolución, ya sean míticas o científicas, muestran el afán de la humanidad por encontrar una explicación, y se pueden ver algunas coincidencias que muestran la universalidad del pensamiento humano. Con expresiones diferentes e imágenes también diferentes, sostenían algunos datos que tenían las mismas bases verdaderas, como hemos descubierto en la actualidad.

Como veremos con más detalle más adelante, sobre todo en la física actual, las explicaciones que se manejan pueden llegar a parecer tan inverosímiles y sorprendentes como las imágenes que explicaban el mundo a los antiguos. La ruptura con las ideas que se manejaron hasta hace 100 años, ha llevado al descubrimiento de mundos inimaginados, teorías que cuestionan la realidad

\footnotetext{
82"There is much more to physics that solving equations and interpreting data. I dare say that there is poetry in physics, that physics is a deeply human expression of our reverence for the beauty of nature." (Tr. Eugenia Yllades). Gleiser, Marcelo. The dancing Universe, p. XIII.
} 
tal y como la percibimos y que ante los ojos del neófito tendrían un significado oculto y casi mágico.

La lógica de las antiguas creencias llevó a sacar conclusiones que ahora se ven confirmadas y ampliadas por la ciencia moderna; por ejemplo, la prueba de otros mundos que no percibimos con los sentidos, cosa que se puede constatar en la actualidad científicamente porque existen mundos microscópicos, objetos en el universo que nunca seremos capaces de ver, o la energía que atraviesa nuestros cuerpos continuamente.

Pero pareciera que sólo en la superficie hay esta coincidencia, porque la ciencia se ha ocupado de desmenuzar ese entramado capa por capa y aspira a llegar a todos los niveles de conocimiento y exploración de las realidades existentes por medio de experimentos y demostraciones matemáticas.

La rama de la física que en la actualidad está permitiendo progresos evidentes en la explicación del origen de todo lo existente se llama cosmología, y es la observación del cosmos la manera por la cual los pueblos antiguos se explicaban también el origen del mundo y el universo. Entonces podemos afirmar que el pensamiento humano siempre se ha dirigido a los mismos lugares, en diferentes vehículos y por diferentes caminos, pero siempre tratando de descifrar los enigmas que nos abarcan a todos. Siempre se ha buscado el enriquecimiento del mundo. 
Uno de los temas que el ser humano tiene forzosamente que aceptar es el de la muerte. La religión se ha construido para satisfacer las necesidades no materiales del individuo y en todas las culturas ha proporcionado cierta tranquilidad respecto a lo que sigue después de vivir en este mundo.

También la ciencia juega su papel en ese aspecto, pues creo que los individuos que no profesan religión alguna encuentran en el entendimiento de la realidad la explicación a sus preguntas y encuentran tranquilidad ante lo desconocido, haciéndolo un poquito más conocido. La diferencia estribaría en que la ciencia ofrece explicaciones que no tienen que ver con un sentido moral y son válidas para todos los individuos de todas las creencias.

"Por su propia naturaleza, la ciencia ofrece respuestas universales, independientemente de una religión o un particular punto de vista. Cuando los científicos van hacia el origen del universo, ellos juegan, por lo menos en la sociedad en general, el papel de hacedores de mitos universales, trascendiendo fronteras de raza y credo." 83

${ }^{83}$ Gleiser, Marcelo. The dancing Universe, p. 6. (Tr. Eugenia Yllades). 
Otra diferencia residiría también en la experimentación, pues las teorías científicas pueden rebatirse e incluso modificarse, de hecho cambian cada vez que se hace un nuevo descubrimiento, pero ambos, el mito y la ciencia, ofrecen una posibilidad de orden según las creencias que elijamos tener acerca del universo en el que nos encontramos.

Son dos cauces pues, en los que podemos percibir la historia del mundo hasta nuestros días: el conocimiento empírico convertido en cuestiones plásticas para un mejor entendimiento al representar dioses y fuerzas divinas, y por otro lado el avance de la ciencia, con hallazgos sujetos a prueba a partir de preguntas y datos planteados por los seres humanos de todas las épocas.

En la actualidad una gran parte de los seres humanos elige una de las dos vertientes, la explicación religiosa o la científica, aunque otros se quedan entre los dos caminos; los individuos eligen su camino para tener una cierta tranquilidad interior, para, como dice Gleiser, encontrar el antídoto del miedo. La gran variedad de posturas actuales nos demuestra que el individuo sigue por los dos cauces y sus variaciones, haciendo coexistir el mito y la ciencia hasta nuestros días.

La necesidad de saber nuestro origen siempre ha estado en la mente del ser humano y ha superado las barreras del tiempo y del espacio, pues ha surgido tanto en los 
más remotos y primitivos grupos humanos, como en las sociedades más complejas y recientes.

El individuo tiene una necesidad psicológica de entender el mundo en el que se mueve, de asimilar lo que le rodea para sentir que tiene un poco de control sobre la realidad. Hay una parte en el ser humano que busca siempre respuestas que pueda hacer suyas, sentirlas en su parte espiritual. No podemos negar que hay algo más allá de los puros conocimientos exactos; se busca una satisfacción interior que no nos pueden dar los datos duros.

En la antigüedad, los mitos proporcionaban esa síntesis de conocimiento, espiritualidad y expresión plástica que necesita el ser humano para sentirse completo, para aceptar más íntimamente el universo como parte de sí. Ahora esas partes encuentran su explicación separadamente y se torna en inquietud y desesperanza cuando los individuos no pueden encontrar el equilibrio entre ellas.

Muchas cosas las podemos comprender por fórmulas y técnicas que se han desarrollado a lo largo del tiempo, pero hay una parte de la realidad, por ejemplo la imaginación, los sentimientos, y sobre todo la creatividad -que da origen a algo verdaderamente nuevo, es decir crea-, que no forma parte de aquel conjunto. El ser original no significa únicamente sumar resultados que se 
van obteniendo, involucra un proceso distinto que percibe otros órdenes de relación por medio de una sensibilidad dirigida al proceso creativo, la cual es desarrollada por medio del ingenio y la imaginación, puesto en práctica por medio de la voluntad, y desplegando la conciencia de dicho proceso para, en la siguiente ocasión, descubrir nuevas conexiones entre las cosas.

Esa sensibilidad tiene que ser capaz de distinguir entre lo igual y lo distinto, de captar esas relaciones que no han sido descubiertas, de partir de lo conocido hacia una nueva manera de mostrar las cosas. La introspección que se lleva a cabo construye estructuras mentales de las que surgen nuevos conceptos y se plasman ya sea en ecuaciones matemáticas, obras de arte, o en cualquier actividad creativa.

En la vida cotidiana aceptamos patrones ya establecidos, es mucho más fácil aceptar lo que damos por sentado y movernos dentro de esos acotamientos de seguridad que nos proporcionan un sentido de que el mundo a nuestro alrededor no es un caos, sino algo ordenado y coherente, por lo menos en la superficie. Pero como dice David Bohm, un reconocido físico teórico que ha tenido un gran acercamiento a las artes,

"la creatividad latente en cada persona se podría expresar hasta un grado mucho más allá de lo que 
en general se considera posible, si no fuera por los "bloqueos" conservados por la cultura." 84

Según este autor, la creatividad en nuestra sociedad se ve inhibida por la confusión, a la que divide en dos: la confusión simple y la confusión autoalimentada. La primera sería cuando no entendemos algo y no encontramos la solución al problema y la segunda es cuando concientemente evitamos enfrentarnos a los problemas que se nos presentan; no queremos aclararlo, preferimos ignorar lo que sucede antes que pensar en ello.

Esto último, como se ha dicho, es cosa común en la sociedad de hoy y nos es más fácil seguir los patrones ya dados. Bohm incluso afirma que esto es un mal endémico en nuestra cultura, porque la apatía reina y se deja a la mente seguir su propio ritmo sin sentido; dejamos que los pensamientos nos ocurran, en vez de estructurar el pensamiento. De hecho se considera el estado normal, y muy pocos dirigen su conciencia al asunto de dirigir los pensamientos. La introspección es necesaria para la creatividad y para la creación de belleza, así como para el desarrollo del pensamiento científico.

Tener la conciencia de este proceso nos ayuda a la creatividad y no es necesario un proceso complicado,

${ }^{84}$ Bohm, David. Sobre la creatividad, p. 10. 
simplemente, dice Bohm, basta con poner atención a dicha confusión. Aunque parece contradictorio, realmente es una acción simple, pero no estamos acostumbrados a hacerlo sistemáticamente. Debido a esa atención es que la mente recobra su estado natural y su pleno funcionamiento para dar paso a la verdadera creatividad.

En la sociedad contemporánea nos limitamos a reaccionar a los distintos estímulos que el entorno nos lanza, no tenemos esa necesidad que el habitante de las primeras comunidades tenía de darle sentido a lo circundante y de relacionarse con él. Ahora seguimos patrones, como ya se mencionó, encontramos ese sentido ya elaborado, alguien más lo hizo por nosotros, y nos relacionamos ya no directamente con el cosmos o con la naturaleza, sino a través de dichos patrones y convenciones que hoy, en la era de las comunicaciones es fácil transmitir a un nivel de alcance nunca antes visto.

Se puede ver más profundamente en los conceptos de Pierre Bourdieu de habitus, cómo se establecen las relaciones entre la interioridad y lo social, para la conservación del orden establecido

...como ya analizamos con anterioridad, el habitus como interiorización de la exterioridad, implica también la incorporación en los cuerpos de las relaciones de poder constitutivas de la 
sociedad. El ocultamiento del arbitrario cultural en el cuerpo lo pone fuera del alcance de la conciencia, y por eso fuera de las tentativas fáciles de transformación por un acto de voluntad.

El arbitrario cultural está de este modo introducido en el cuerpo por una especie de pedagogía clandestina, sobre-entendida, implícita, que valoriza las posturas, los gestos, los lugares. Esta inculcación produce una transustanciación de gestos y detalles que en sí mismos son neutros, en la expresión de una ética, una metafísica, y una política. El "respeto de las formas y las formas del respeto" se transforman en "la manifestación más visible, y al mismo tiempo mejor oculta porque más "natural", de la sumisión al orden establecido". (Martinez, 2007:144). ${ }^{85}$

Mientras que en las sociedades arcaicas todo formaba parte de la misma unidad, ahora recibimos el conocimiento fragmentado; el conocimiento científico nos informa de partes reducidas y bien estudiadas en su particularidad, el conocimiento artístico nos llega por un lado diferente y pasa a formar parte de ese rompecabezas que conforma nuestra percepción del mundo. No vemos ya la totalidad, y nuestros juicios y pensamientos, así

85 Véase: dialnet.unirioja.es/descarga/articulo/3874067.pdf 
como las acciones sobre la realidad se ven afectados por ello.

Tanto en la ciencia como en el arte, se trata de evidenciar algo que es coherente, ininterrumpido e íntegro, pero para eso se ha fragmentado el acercamiento hacia las cosas y aunque la ciencia trabaja con abstracciones y números y el arte trabaja sobre los medios, ambas quieren descubrir y poner ante nuestros ojos algo de la "verdad". Pero no siempre ha sido así,

“...es la orientación particular de la abstracción del siglo XX la que revela una afinidad con el trabajo de los físicos y los matemáticos." ${ }^{86}$

Los pintores cubistas muestran cómo su mente llegó a percibir la realidad de una nueva manera, llevaron la mente hasta la parte más básica para dar lugar a una percepción distinta y por tanto a una expresión totalmente nueva, rompiendo con los esquemas que condicionaban a la gente, adquiriendo una nueva y nunca antes explorada perspectiva.

La ciencia por su parte, siempre está desarrollando modelos a partir de los datos obtenidos y a veces también cae en la inercia de tal o cual teoría, pero no faltará quién brinque las trancas y recorra otros senderos y de hecho

${ }^{86}$ Bohm, David. La creatividad, p. 14. 
hoy se espera que los científicos se acerquen a otras disciplinas consideradas no tan científicas para aprender de ellas y enriquecer la creatividad que finalmente es la que guía el entendimiento del mundo.

Siguiendo de nuevo a Bohm, ${ }^{87}$ me gustaría aquí mencionar las actividades mentales que están involucradas en el pensamiento creativo: las llama "revelación" racional e imaginativa y la "fantasía" racional e imaginativa.

La revelación imaginativa sería cuando se descubre una imagen nueva del problema, se adquiere una visión de totalidad y de que los fenómenos similares se comportarán igual, esta revelación no surge de la asociación ni de la deducción, simplemente aparece como actividad simple de la mente. De ahí surgen las revelaciones racionales que explicarán esa imagen con argumentos sistemáticos y coherentes, que ponen lo descubierto de manera que sea discernible para que los demás la puedan entender.

La fantasía imaginativa permitiría entonces pensar en otros procesos que pudieran verse afectados por el descubrimiento, se hacen asociaciones con distintos fenómenos para producir hipótesis desde distintos ángulos, y se explican distintos aspectos de la revelación. Esto provoca la fantasía racional que hace que surjan

${ }^{87}$ Bohm, David. Sobre la creatividad, p. 85. 
nuevas conjeturas y líneas de investigación apoyadas ya por las hipótesis básicas e impulsa el desarrollo de nuevos puntos de vista que permitirán ver las contradicciones y fallas de lo establecido anteriormente.

Esto no es un proceso lineal ni autónomo en cada una de sus partes; Bohm afirma que se interrelacionan y dan lugar a un ciclo que impide el anquilosamiento de la mente y sus funciones. Es la red que se teje en el pensamiento. Esto es muy interesante porque al aplicarlo a la cuestión mítica y a la científica, junto con la parte artística, puede tener implicaciones importantes.

Desde luego que actualmente podemos ver la cada vez más patente interrelación entre las distintas disciplinas que conforman el saber humano; pareciera, —y ojalá así sea-, que después de la fragmentación de que han sido objeto todos los aspectos del saber humano, se está atisbando una reagrupación entre las diversas materias para enriquecer y facilitar la extracción de conclusiones que amplíen el saber.

A mi parecer, solamente aniquilando la fragmentación, viendo lo existente como parte de un todo que se interrelaciona, es posible que la humanidad encuentre una explicación y solución a los problemas que la aquejan, tanto social, como individualmente.

Los físicos del siglo $\mathrm{XX}$, dice Bohm, han tenido que modificar su visión del mundo. Desde cierto sector de la 
física se intenta ver no sólo la abstracción teórica, sino la conexión con el mundo real, con lo que sucede alrededor, pero no sólo como un proceso aislado que se puede estudiar con la ciencia, sino como una totalidad con un sinnúmero de conexiones entre las cosas existentes.

Tratando de quitar los condicionamientos a los que la mente se sujeta por comodidad o aceptación, varios físicos ejercen el pensamiento reactivo y reflexivo, pero manteniéndolo abierto a nuevas posibilidades saliendo de los patrones dados y tratando de encontrar una concordancia entre todos los sectores del universo.

El que las teorías de lo muy pequeño no funcionen en los sectores de lo muy grande, y que se hayan formulado teorías que buscan una explicación coherente para ambos mundos, ha permitido la apertura del pensamiento y la intervención de la inteligencia para comprender estos nuevos planteamientos.

Hay esfuerzos muy numerosos de científicos que están volteando hacia otros sectores más allá de la ciencia, acercándose más al ser humano y la totalidad de lo que ha creado, como veremos más adelante, por lo que se está ampliando el terreno en el que la ciencia puede indagar para encontrar posibles respuestas.

Como en los mitos antiguos, el arte y la ciencia se acercan ahora con el fin de que el ser humano se sienta más cómodo en el mundo, aunque como ya se mencionó, 
la ciencia intenta encontrar respuestas que vayan más allá de cualquier creencia. Nuestros mitos son ahora modernos y fragmentarios, en el sentido en que cada individuo cree que posee la parte de verdad que necesita y le satisface, pero la naturaleza y el universo no funcionan así; todo es una totalidad en movimiento, y esa totalidad es la que en los últimos años hemos desmembrado para sentir que nos acercamos más fácilmente a ella.

Los cauces de explicación y de expresión han cambiado a lo largo de la historia y es necesario que una vez más cambien, que nos salgamos de lo establecido para lograr un mayor entendimiento y comprensión del mundo del que formamos parte y en el que nos movemos. La religión todavía ejerce su influencia en las sociedades contemporáneas, pero ahora permeada por el descubrimiento científico.

"La ciencia ha hecho que a la mayoría de las personas les resultara imposible aceptar la mitología religiosa literalmente, y por consiguiente, lo que queda es una vaga y confusa idea de algún tipo de Dios junto con varios fragmentos de autoconocimiento en forma de preceptos morales." 88

${ }^{88}$ Bohm, David. Sobre la creatividad, p. 68. 
Pero aún así, alrededor de las tres cuartas partes de la población humana profesa alguna religión, es decir que el elemento mitológico sigue presente hasta nuestros días. Es parte importante del ser humano pues llena una necesidad primitiva del individuo. La pulsión de lo más selvático del ser humano sigue vigente por encima de la visión científica.

No podemos ignorar lo anterior, pero de igual manera, arte, ciencia y religión siguen coexistiendo en nuestro tiempo y ahí se desarrollan expresiones y construcciones que nos proporcionan satisfacción en diversos planos de nuestra existencia. En el grado en que logremos percibir nuestro entorno como parte de una totalidad -y para esto la metáfora de un tejido del que todos somos parte es muy útil-, podremos tener esa satisfacción interior que proporcionará la tranquilidad de la que en este punto la sociedad carece.

En los siguientes párrafos abundaremos en los mitos que aún son vigentes en culturas actuales para hacer un reconocimiento del pensamiento religioso que no se separa fácilmente del ser humano y que pretende interconectar tanto las acciones humanas como las de la naturaleza y también abordaremos el cauce que se ha seguido nuestra época para dar respuesta a las preguntas sobre el origen de todas las cosas. Veremos también 
cómo las ciencias se plantean el origen en cada uno de sus campos y finalmente enumeraremos algunas de las metáforas que tienen relación con los elementos del tejido. 


\subsubsection{SENTIDO MITOLÓGICO}

En nuestra época llamamos mitos tanto a los mitos griegos como a los mitos de las sociedades primitivas, pero los expertos en el tema nos hacen notar que, aunque tienen similitudes, las diferencias de mentalidad de las sociedades que los producen, son abismales. Los mitos de los indígenas, tanto en Australia como en África y América, obedecen a estructuras conceptuales muy diferentes por lo que se preguntan algunos estudiosos si es legítimo aplicarles la sistematización a la que está sometido nuestro pensamiento contemporáneo.

Las categorías lógicas y de coherencia que manejamos en el saber contemporáneo, además de la manera en que estructuramos nuestros análisis de los problemas, no corresponden a la manera de pensar de las sociedades arcaicas. Ellos no buscan la causa, tal y como lo hacemos en la filosofía actual,

"Puesto que esa causa se les presenta de antemano, no tienen que filosofar. Sin duda son metafísicos, pero no por apetito de saber. Lo son por un movimiento espontáneo, por la experiencia frecuente, podríamos decir permanente, que 
tienen de una realidad que supera y domina el curso ordinario de la naturaleza y que interviene en ella en todo momento." 89

La mitología formaba parte, como un todo, de lo sobrenatural, de lo que está más allá de la experiencia ordinaria, y muchos objetos, actos, lugares, pertenecían a esa categoría de sagrados. El hombre primitivo aceptaba el desconocimiento de muchas causas de las cosas, y sin embargo su conocimiento del mundo, sobre todo de los sacerdotes o gobernantes como depositarios del saber, era profundo. Para ellos existen mundos distintos, aunque no separados y son los mitos los que permiten la comunicación entre dichos mundos.

Parece ser que quienes estudian los mitos de una manera más profunda, están de acuerdo en que el modo de pensar arcaico nos es ajeno y que ahora utilizamos un aparato cognoscitivo muy distinto a aquellas mentalidades. Tendríamos que intentar dejar a un lado nuestros esquemas de pensamiento para acercarnos un poco e intentar comprender la concepción del origen de todas las cosas y su desarrollo tal y como lo veían los indígenas. Pero Levi-Strauss ya ha reflexionado sobre el

${ }^{89}$ Levy-Bruhl, Lucien. La mitología primitiva, p. 36. 
problema del enfrentarse a otras concepciones y maneras de vivir. ${ }^{90}$

Para nosotros, el mundo es un modelo construido con orden, jerarquía y racionalidad, pero siguiendo a LevyBruhl, los mundos sobrenaturales de las comunidades primitivas no están construidos de esa manera. Nos puede parecer que los dioses y las fuerzas que manejan no tienen relación e incluso hasta que se contradicen, pero en realidad para ellos formaban parte de un todo que les daba respuesta a las preguntas particulares que se hacían.

Las cosas que a nosotros nos parece importante que guarden cierta lógica, para ellos no tenían la mínima importancia; ellos no buscaban la congruencia tal y como la necesitamos ahora; la estructura relacional de todas las cosas y de los mundos que concebían no tenía fragmentaciones, era una totalidad y los distintos planos se confundían entre sí, sin que fuera un obstáculo en el desarrollo de su pensamiento. Se han hecho investigaciones importantes en las culturas arcaicas que sobrevivieron hasta el siglo XX y se han encontrado múltiples ejemplos de esta manera distinta de pensar.

La cuestión del tiempo es una arista importante en la concepción mítica. El tiempo terrestre no es como el tiempo mitológico o sobrenatural. El tiempo humano

90 Ver la obra de Levi-Strauss Tristes Trópicos. 
participa del tiempo mítico y ambos conforman el acontecer del mundo. Los relojes no medían el tiempo, eran los sucesos de la naturaleza, los acontecimientos cíclicos quienes daban la pauta para la actividad humana. La luz del día y el avance del sol eran los parámetros a seguir para la realización de los deberes.

Parece ser que el tiempo en sus intervalos más cortos no era tan importante. El tiempo histórico muchas veces no tenía fechas, sólo se consideraba un tiempo anterior, a veces no tan lejano y otras veces ligado con los primeros inicios del cosmos. Los actos sagrados, transcurren en dos momentos simultáneamente: por ejemplo el sacrificio, ocurre en tiempo real del momento en que se realiza la actividad, pero también está ocurriendo en el tiempo mítico al ser una repetición de un acto divino, primordial, ligado a la creación, además de acceder a planos a los que normalmente no se accede en las acciones cotidianas.

La concepción del tiempo entre los arcaicos difiere con mucho de nuestra visión. Sería como en la cosmología contemporánea, la luz que recibimos de las estrellas es una luz que ya fue emitida hace mucho tiempo, no es la luz que está emitiendo la estrella en el momento, podríamos decir que es una luz vieja e incluso sería posible recibir luz de una estrella que en este momento 
real del tiempo en la tierra, ya se ha apagado. Hay una diferencia en los tiempos cosmológico y terreno.

Entre las sociedades primitivas, las actividades que no están ligadas a algo sagrado, pertenecen al tiempo profano, al tiempo propio de los individuos, al tiempo en el que la muerte define la duración. Para los pueblos de Mesoamérica el tiempo que pasaban en el mundo era transitorio, y luego de la muerte, se va a otros mundos, a otro tiempo que no transcurre como el del mundo. La muerte simboliza la transición, y permite ir al reino de los dioses, no es algo trágico, sólo representa la conductora hacia nuevas realidades.

De ahí la peculiar relación de los mexicanos ante la figura de la muerte que se conserva como parte de nuestra cultura antigua. Es posible verla con humor porque termina con el sufrimiento en la tierra y nos da la posibilidad de entrar al mundo sagrado, de volver a ser parte del ciclo del universo, de formar parte del todo y establecer la conexión con otros planos.

El tiempo de la historia transcurre para los arcaicos, pero no tiene tanto valor. Los hechos históricos adquieren importancia sólo en cuanto están ligados a los hechos sagrados. El pasado del ser humano no importa por sí mismo sino a partir de su relación con lo sagrado. 
"Como el místico, como el hombre religioso en general, el primitivo vive en un continuo presente". 91

El tiempo importante es el que repite las acciones divinas en el mundo humano. Los actos profanos son los que construyen la historia y por tanto no se les presta mucha atención, ya que lo importante son los actos sagrados, aquellos que repiten el arquetipo que los dioses nos han enseñado.

\begin{abstract}
"Por consiguiente, todo drama, toda lucha histórica, deben conectarse con el drama de la creación mediante un lazo de unión, cual es la reproducción, repetición o representación del tipo cultural-ritual." 92
\end{abstract}

La vertiente religiosa se distingue porque hay un requerimiento de adoración, un sometimiento ante la voluntad divina, y el temor de que las fallas humanas ocasionen catástrofes que afecten a los individuos. Por eso es importante el ritual en todas las religiones, porque asegura el cumplimiento de las demandas divinas. Estamos condicionados a responder a nuestras obligaciones so pena de disgustar a los dioses y atraer

91 Eliade, Mircea. El mito del eterno retorno, p. 83.

92 Ricoeur, Paul. Finitud y culpabilidad, p. 344. 
castigos sobre nosotros. En las sociedades antiguas, si se dejaba de lado la adoración y la satisfacción de los dioses, se corría el riesgo de que el universo entero no funcionara correctamente.

Los mitos de las grandes culturas se nos presentan como la demostración de que el ser humano ha tenido siempre que buscar una explicación a su origen. Veremos en seguida muy brevemente las concepciones que sobre el origen tienen algunas culturas antiguas y las religiones más importantes para tener una idea del pensamiento mítico que se maneja en cada una de ellas y encontrar ciertos elementos que se repiten en distintas concepciones.

-En la cultura china, una divinidad primordial Ilamada Phan-ku surgió de las fuerzas complementarias del Ying y el Yang; incubado en un huevo primordial, creció durante un largo periodo de tiempo y al salir del huevo creó el cielo y la tierra quedando Phan-ku como sostén entre ambos.

Todo surgió de ese huevo y cuando Phan-ku murió, de su aliento surgió el viento y las nubes y de sus ojos el sol y la luna y de cada una de sus partes un elemento de la naturaleza, así como las montañas, la lluvia y todo lo que existe en el mundo. Pero aún no estaba el ser humano, y una diosa Un Kuah, formó la figura del hombre con arcilla 
amarilla pero al ser una tarea muy pesada, prefirió tomar una cuerda ${ }^{93}$ que empapó en arcilla y dejó que goteara, saliendo un hombre de cada gota que salía de esa cuerda.

En este mito se puede ver la dualidad como origen primero de todas las cosas. La diosa y la cuerda formaron al hombre, la cuerda como facilitadora y vínculo entre lo divino y lo humano. También existen registros de otro nombre de la diosa primordial, Nüwa, que crea todo lo existente pero no muere al hacerlo.

-En el mito escandinavo de la creación, los gigantes y dioses entablaban fieras luchas y se mencionan la manifestación del fuego volcánico y los grandes hielos, así como remolinos de los que surgían cosas. De uno de ellos nació el molde para la tierra, pues cuando murió el dios Ymer, los demás dioses lo ataron (con una cuerda) a un molino, y de su sangre y partes del cuerpo surgieron todas las cosas que forman y habitan en la tierra, y aún después siguieron poniendo gigantes en el molino para seguir dando forma al mundo.

Del cabello (de nuevo el cabello como símbolo cercano al surgimiento de las cosas) de Ymer surgieron los bosques y una vez, los hijos de uno de los dioses encontraron en la orilla de la playa dos troncos, uno de fresno, del que

${ }^{93}$ Nótese la mención de la cuerda como vehículo de vida. 
formaron al hombre y el otro de un árbol llamado aliso del que formaron a la mujer y les dieron mente, voluntad y deseo y de ahí surgió toda la raza humana. ${ }^{94}$

El fuego y el hielo son aquí la dualidad de la que surge lo existente. La destrucción y la batalla entre los dioses era fuente de creación. Aquí no es el dios pasivo, tranquilo y cómodo que crea el mundo desde su sillón, sino son dioses guerreros, violentos, jugando con los elementos más salvajes y difíciles de dominar.

Esa actividad eruptiva, tal como los volcanes, da origen al surgimiento del mundo por medio del sacrificio y de la distribución de la materia corporal de los gigantes. Aquí el mundo humano es resultado de las luchas divinas.

-En Egipto hay varias versiones del mito de la creación, según la época y la hegemonía de las ciudades, pero todas coinciden en que del caos surgió un centro, y los dioses o un solo dios, crearon el orden. También contienen elementos tales como las aguas del océano primordial y el aliento de los dioses o el ojo del dios como generadores de vida.

Según la versión heliopolitana, de la saliva del dios $\mathrm{Ra}$ surgieron los dioses que crearon el mundo y de las aguas surge una colina de la que saldrá todo lo existente. En la

${ }^{94}$ Teutones. Mitos y leyendas. (Comp. Donald Mackenzie). Ed. Studio. 
concepción hermopolitana existían 4 parejas representantes de las cualidades del caos; las tinieblas, el infinito, la determinación y lo oculto, y ellas engendraron un huevo del que surgió el sol. Otro culto era una especie de asimilación de los dos anteriores, la idea de Memphis afirma que el dios creador se llama Ptha y de él surgen otros dioses, de los cuales el dios Atum es el pensamiento, Horus su corazón y Toht la lengua. ${ }^{95}$

-Existen muchas tribus australianas y cada una tiene diferentes particularidades en sus mitos, pero podemos decir que en el mito australiano había un mundo primigenio donde moraban los dioses y de ahí surgieron los seres humanos y la tierra en la que vivirían. Ese mundo tiene un tiempo eterno donde se hicieron por primera vez todas las cosas llamado el mundo de los Sueños y se puede acceder a él por medio del ritual. En ese tiempo sólo había una materia oscura e informe en la que los dioses actuaron para crear todo lo que existe y esas acciones son las que los humanos siguen teniendo como modelo y realizando en este tiempo terrenal.

El acceso a lo divino por medio del ritual se hace patente en estos mitos australianos. Los mundos de la ensoñación y la materia originaria de la que los dioses sacaron la

${ }_{95}$ Davinia Albalat en Armour, Robert A. Dioses y Mitos del Antiguo Egipto. Ed. Alianza, Madrid, 2004.

http://www.uji.es/bin/publ/edicions/fifi2/24.pdf. 
materia, actúan como realidades a las que se tiene que aspirar. El ritual y la imitación permiten ese contacto con lo superior.

-Seguimos con el brahmanismo, donde se concibió el origen a partir de las aguas primordiales del océano al que los dioses dieron vuelta o revolvieron para hacer surgir todo lo existente. En esta concepción los montes, la serpiente y el océano tienen un papel importante en el surgimiento de la vida.

Los Upanishad hablan sobre el principio y sobre una entidad a la que llaman Él que es el Dios único y creador, quien existía solo y pensó que quería crear los mundos. Y creó las aguas, el cielo y la tierra sacando al hombre cósmico de las aguas primordiales. Lo incubó en su boca y salió rompiéndose como un huevo.

De este hombre cósmico salieron todas las cosas existentes, de cada una de sus partes surgió todo lo que existe en el universo. El hombre cósmico, por tanto, es el origen de todas las cosas de la naturaleza; surgen de él las distintas divinidades de las fuerzas que se manifiestan en el mundo. La sabiduría y el conocimiento son los que guían al mundo. La mujer es la copartícipe de la perpetuación del hombre. 
"Primer fragmento

PRIMER KAHNDA

1. Sólo Él estaba en el principio. Nadie más que Él parpadeaba. Él pensó: Quiero crear los mundos.

2. Él creó estos mundos: el oleaje, los rayos luminosos, la muerte, las aguas. La marejada está allá, más allá del cielo y el cielo son los cimientos; los rayos luminosos son el espacio intermedio; (el territorio) de la muerte es la tierra. Las que están por debajo son las aguas.

3. Él pensó "He aquí los mundos, quiero crear los protectores de los mundos. Sacando de las aguas al Hombre le dio su forma. (Este hombre es una referencia (...) relativo a un hombre cósmico originario que fue sacrificado por los dioses).

4. Él lo incubó. Habiéndolo incubado su boca, salió, rompiéndose como un huevo; de su boca la palabra y de la palabra el fuego." ${ }^{96}$

Esta es la referencia al origen en los Upanishad y sigue enumerando todo lo que surgió a partir de ese hombre primordial. En este sentido el hombre es un pequeño cosmos, es réplica de todo lo que existe en el universo y de él han surgido cosas nuevas, por eso el hombre tiene

96 De Mora, Juan Miguel, Tr. e Intr. Los Upanisad, p. 19. 
la capacidad de crear si se pone en contacto con las fuerzas de la naturaleza y con lo sagrado.

-El Rg Veda, columna vertebral del hinduísmo es un libro compuesto alrededor de dos milenios antes de nuestra era; es de los libros más antiguos que posee la humanidad. En él se encuentran conocimientos que sólo se abordaron y se sostuvieron como científicos, milenios después de su composición; este libro contiene la sabiduría de esa época antiquísima.

Juan Miguel de Mora, erudito estudioso de las religiones en la India, afirma que el hinduísmo es la religión más grande por su número de fieles y la de más larga duración. En el $\mathrm{Rg}$ Veda se han encontrado conocimientos tales como el ciclo de la lluvia, que, aunque no están objetivados ni sistematizados, están claramente planteados. También, por poner otro ejemplo, se menciona que la vida proviene del agua o que el universo todo surgió de la energía. Los mitos surgen de hechos, a veces insignificantes - que son conocidos por la cultura que crea el mito. En los Rg Veda se menciona también a la mujer creadora y a una pareja de gemelos, elemento que es común en varios mitos de la creación. El agua sigue siendo el origen, y su importancia la demuestran los siguientes versos que son un elogio a las aguas primordiales. 
"Dadnos grandeza, alegría y saber, aguas que otorgáis fortaleza, dadnos consuelo. Como madres cariñosas dadnos parte aquí de vuestro jugo benefactor. Aquel a cuya casa nos inducís, aguas, será a quien serviremos, ¡oh, aguas, de donde surgimos!" $(X 9,1,2,3)^{97}$

"En la etapa primitiva de los dioses el Ser nació del no-Ser. En la edad primitiva de los dioses, el Ser nació del no-Ser. Inmediatamente después nacieron orígenes, y después la fuerza que se mueve hacia arriba. De la fuerza hacia arriba nació la tierra y de la tierra nacieron los comienzos:" $((X 72,3,4)$

-En el Sefer letzirá, libro de la creación de la cábala, se habla sobre la existencia de un solo dios verdadero y único; él hizo todo lo que existe
Por 32 senderos misteriosos de Sabiduría (...) y creó el Universo mediante 3 registros; con el Número, la Palabra y la Escritura (...) Diez emanaciones de la Nada material e indefinible tantas como el número de diez dedos, donde cinco

97 De Mora, Juan Miguel, Tr. e Intr. El Rig Veda Samhita. (La cita de los himnos está entre paréntesis al final de los versos). 
corresponden a cinco y un acuerdo único los rige eternamente; mediante la palabra de la lengua y con el término de la desnudez. (Cap. I Sección 1).

Es evidente que toda la creación y toda la palabra sale de un sólo Nombre. (Cap. II, Sección 5),

Creó realidad del vacío y existencia de la Nada;" (Cap. II Sección 6) ${ }^{98}$

En este proceso cabalístico de creación, la palabra y el aliento son los que van formando el balance necesario para la existencia de las cosas en el mundo. Las letras y los números, son los que contienen el misterio de la creación. Las combinaciones de letras y números es el fundamento de todo lo que existe. Todo, dicen, se deriva de un sólo nombre. Existe también la lucha de los contrarios, la dualidad que se enfrenta y que es conciliada por un tercero.

La doctrina secreta de los judíos contiene la relación de la explosión del átomo y del universo en expansión. ${ }^{99}$ Para los judíos, tanto la Ley de Moisés como el Universo y el ser humano son reflejo directo de Dios y tienen cada uno un cuerpo físico que está compuesto por un ternario, un septenario y un duodenario. En la Torá está toda la sabiduría y por ser emanación de Dios, no se puede cambiar. El universo tiene el sello de Dios, quien lo creó,

98 Goldman, Moisés. La doctrina secreta, p. 309.

99 Ibid. P. 19. 
pero no es Dios. Esto nos indica que tiene una existencia separada y que no existe esa pertenencia al creador, sino en cuanto a que somos parte de su obra. En la tradición judaica también existen conocimientos sobre hechos que se probaron científicamente más tarde. Se afirma que se conocía ya la redondez de la tierra mencionándose en el Talmud; la relatividad; las reflexiones sobre el sexo de las que se ocupa la Cabalá; y los estudiosos creen que también habla de la cuarta dimensión; del sistema circulatorio y varias cosas más.

-La tradición cristiana descansa en las palabras escritas en la Biblia. Ahí también se describe el principio de la tierra:

"1,1 Al principio creó Dios el cielo y la tierra.

1,2 Pero la tierra era informe y vacía y las tinieblas cubrían la superficie del abismo y el Espíritu de Dios se cernía sobre las aguas.

1,3 Dios dijo: Haya luz. Y hubo luz.

1,4 Y vio Dios que la luz era buena y separó la luz de las tinieblas.

E hizo lumbreras.

1,15 A fin de que brillen en el firmamento del cielo, y alumbren la tierra. Y así se hizo. 
2,7 Entonces Dios formó al hombre del lodo de la tierra, e inspiróle en el rostro un soplo de vida, y quedó hecho el hombre, ser con alma viviente."100

La tradición cristiana nos muestra a un Dios omnipotente y creador de todo. El ser humano es parte de su obra y es quien está destinado a disfrutar todo lo que existe, excepto por un árbol, el de la ciencia del bien y del mal. ¿Tuvo el primer hombre curiosidad por saber acerca del origen y la creación? Parece ser que sí, pues gracias a eso consiguió que lo echaran del paraíso, aunque me parece que Dios lo creó con esa necesidad de respuestas. En el cristianismo, al tener acceso a la dualidad bien-mal, el ser humano quedó condenado a estar fuera de la creación original y aún hoy es ajeno a lo sagrado, no tiene un papel qué jugar para la conservación del orden en el cosmos.

Entre los varios planteamientos anteriores acerca de cómo se originó el mundo, podemos encontrar estructuras básicas con algunas coincidencias: el creador quiso dar vida a las formas; las aguas primordiales tienen un papel protagónico; el verbo, el aliento, la palabra o el espíritu son lo que infunden la vitalidad; la dualidad casi siempre está presente, ya sea en la forma de los contrarios o de

100 Sagrada Biblia. Edit. Herder. Barcelona, 1963. 
una deidad creadora femenina y otra masculina, o de gemelos; la creación culmina con el ser humano como adorador de la deidad y con un papel importante en la existencia del cosmos.

Como podemos ver, en los mitos se encuentran interesantes demostraciones del contenido exacto de apreciación del mundo, relacionados con la actividad que el creador realiza para que todo eso tenga lugar. En los tiempos antiguos, los seres humanos desarrollaron una observación aguda hacia lo que los rodeaba; la naturaleza era observada minuciosamente y con cálculos rudimentarios pudieron explicar y aún intuir algunos trozos de la realidad.

La coincidencia de las líneas generales de los mitos en las grandes religiones, nos muestra la coincidencia del pensamiento humano en diferentes regiones $y$ sociedades. La naturaleza actúa de la misma forma en cualquier parte y su observación lleva al establecimiento de constantes en el pensamiento mítico, así como también ha conducido al establecimiento de hipótesis y leyes en el pensamiento científico.

Estamos muy acostumbrados a la separación entre ciencia y religión, pues ha sido un proceso que se consolidó desde fines de la Edad Media y ha calado hondo en la mente de la humanidad; no se diga con los 
avances del siglo $\mathrm{XX}$, donde la ciencia ha tomado la delantera,

\begin{abstract}
"Esta ciencia no hubiera podido surgir si Dios y los milagros no hubiesen sido previamente descartados de la naturaleza, si las reglas del método científico, tal y como las codificaron en el siglo XVII Bacon, Descartes, Gassendi y otros, no hubiesen descartado cualquier rastro de creencias religiosas, si la ciencia no hubiera sido liberada de todo apego a la tradición, a la autoridad, a la Iglesia y a cualquier cosa que hubiera sido declarada incurablemente misteriosa e inaccesible al intelecto humano."101
\end{abstract}

Claro que no podemos decir que las religiones han quedado obsoletas, pues el gran número de adeptos nos muestra lo contrario. De hecho es posible afirmar que en el momento actual, en pleno auge de la ciencia como líder para explicar el mundo, se ha dado también un aumento en las sectas, grupos espirituales o esotéricos que han surgido para satisfacer la credulidad y la superstición humana.

Esto nos habla de una necesidad de llenar un vacío, una necesidad psicológica o espiritual si se quiere, y que siempre se presenta en alguna etapa de la vida del

101 Kolakowski, Leszek. La modernidad siempre a prueba, p. 140. 
individuo. A la mayoría no le interesa el conocimiento que no sirva para la vida cotidiana, práctica, incluso lo espiritual tiene que estar ligado a las acciones concretas, por lo que el pensamiento abstracto es cultivado por minorías y en realidad son pocos los que se dedican a buscar respuestas que expliquen el orden de todo lo que nos rodea. Los demás nos limitamos a aceptar o no, lo que nos presenten.

Vemos entonces que no podemos negar que el sentido mitológico forma parte de la existencia humana. Es una manera de explicar las preguntas para las que no tenemos respuesta.

No es nuestro deseo aquí decir que los mitos o las religiones son equivalentes a la ciencia, lejos está eso de nuestras intenciones; más bien queremos señalar que en el proceso del pensamiento humano, existe esa conjunción entre el conocimiento científico y la concepción que se encuentra patente en los mitos de las que han sido grandes civilizaciones y por esto queremos señalar que el individuo siempre ha tenido necesidad de expresar en sí mismo ambos aspectos, y esta observación enriquecerá nuestro conocimiento si nos acercamos a ellos con una mente abierta, pensante y sin prejuicios. 


\title{
2.1.2 EXPLICACIÓN CIENTÍFICA
}

\begin{abstract}
"Las visiones del hombre siempre han dependido de lo que le había tocado vivir, de lo que necesitaba creer y de lo que pretendía conocer" 102
\end{abstract}

El entorno donde habita el ser humano hace que tome de ese ambiente conocido las características de sus creencias sobre el universo y el origen de todo lo que existe. La observación de la tierra en donde vive, las montañas, la vegetación, la orografía, las fuentes de agua que tiene a su disposición, etc., le proporcionaron el material para la construcción de sus cosmologías.

Poco a poco encontró las relaciones entre las fuerzas naturales que condicionaban su existencia en el sitio que siente como suyo, e hizo leyes que extendió a otros procesos de su existencia; halló coincidencias que se repetían en distintas acciones o sucesos y extendió su campo de entendimiento.

Los ciclos astronómicos resultaron significativos para su vida, supo que las fuerzas de algo tan lejano como el sol, la luna y las estrellas determinaban los ciclos de su vida

102 Levinas, Marcelo Leonardo. Las imágenes del universo, p.21. 
cotidiana. Su vida transcurría en relación con otros seres humanos y formaban una comunidad que actuaba bajo aquellas influencias del cosmos. La sociedad, pues, tenía que organizarse para responder de alguna manera al influjo de las fuerzas naturales.

Era conveniente, para su tranquilidad y funcionamiento, la formulación de ideas que dieran respuesta a sus inquietudes y cuestionamientos. Las ideas sobre la naturaleza tenían que coincidir con las estructuras sociales en las que se movían los seres humanos, tenían que justificarlas y estar de acuerdo con la mente de la mayoría en su comunidad. Aunque generalmente cada grupo social construía su estructura de creencias, también sucedía que se aceptaban influencias externas, ya sea por dominación o por asimilación.

La explicación del origen y de la existencia del mundo es una sistematización del conocimiento que cada sociedad posee a partir de la observación de los fenómenos y objetos naturales; $y$ debido a que éstos existen sin que el humano tenga ninguna influencia sobre ellos, los seres humanos siempre han sabido que están sujetos a las condiciones que la naturaleza les imponga.

En las sociedades más antiguas, el conocimiento de lo natural se integraba como un todo con las estructuras sociales e incidía directamente en la vida cotidiana, pero al avanzar la civilización, se empezó a aislar el 
conocimiento de lo natural para poder verlo con más detalle. Esto provocó que una determinada sociedad profundizara en el conocimiento de ciertos sectores del mundo natural, dejando de lado otros que no le interesaban en cuanto no servían para justificar la estructura social.

El movimiento de los astros visibles a simple vista, ha provocado a lo largo de la historia, diferentes visiones o planteamientos acerca de ellos, pero el ser humano no puede cambiar la realidad de la naturaleza, no importa si lo comprende o no, si inventa datos o los descubre, si organiza el conocimiento para cualquier objetivo social o religioso, las fuerzas naturales actúan de manera independiente.

El pensamiento dirigido hacia los sucesos naturales ha pasado por muchas etapas; desde las comunidades primitivas donde empezó la apreciación de dichos sucesos como acciones de los dioses y la identificación de los objetos naturales como divinidades, atestiguando el avance de la razón, hasta las revoluciones científicas que impulsaron el conocimiento y la discusión de los antiguos problemas bajo otra perspectiva, siempre desde el trasfondo social. Un abordaje distinto ha tenido lugar según la época en la que se traiga a la mente un determinado problema en la explicación del mundo. 
En los mitos es donde mejor se integraba la sociedad con lo natural, los actos cotidianos con las fuerzas que tenían lugar en el lejano cosmos.

\begin{abstract}
"Con frecuencia, para el hombre antiguo, la imaginación y la rigurosidad, lejos de ser incompatibles, se coordinaron armónicamente dando como resultado el elemento imprescindible para la explicación y la descripción de la realidad."103
\end{abstract}

Como todas las actividades humanas se situaban en un lugar, este lugar formaba parte del espacio que rodeaba al hombre, cercana y lejanamente. Por esto se equilibraban las fuerzas desde lo inmediato hasta los astros que regían el desenvolvimiento del medio ambiente. De ahí se construía un orden, una estructura que permitiera tener seguridad, repeticiones de ciclos que pusieran la vida un poco bajo control. Al descubrir el orden de la naturaleza, se descubrían las regulaciones que se debían imponer en la comunidad. Cuando la sociedad funcionaba de acuerdo a lo natural, se estaba construyendo el orden cósmico.

La reflexión avanzó en la historia, y se plantearon de distinta manera los problemas del conocimiento. La religión empezó a separarse de la naturaleza. Es sobre

103 Levinas, Marcelo Leonardo. Las imágenes del universo, p. 33. 
todo con los griegos con quienes hallamos los planteamientos que aún hoy nos ocupan.

A la creencia religiosa siguió poco a poco un cuestionamiento acerca de lo que nos rodeaba. La especulación dio como resultado una extensión del conocimiento y una nueva actitud: ya no se daba por sentado lo que planteaba la religión sino que se encontraban argumentos distintos para sostener las respuestas que se planteaban. Se buscaban los principios que regían el mundo y formaban parte de todo lo existente, pero ya sin un contenido completamente religioso.

El conocimiento que desarrollaron los griegos profundizó en las preguntas más importantes que se planteaba la humanidad; sus argumentos, la importancia que le dieron a la razón, los distintos abordajes que hacían de cada uno de los asuntos a tratar y las variadas propuestas de solución, dieron como resultado una expansión de la razón humana sin precedentes. Sus posturas dieron origen a muchas reflexiones.

Pero los inicios de la era cristiana trajeron un regreso primero y luego un olvido, dice Levinas, del conocimiento adquirido. Sólo se adoptaron los filósofos que se podían adecuar a lo dicho por las Sagradas Escrituras. El saber tenía que estar dirigido a la teología, no al conocimiento científico considerado pagano. La fe regía toda reflexión 
sobre el mundo y se apoyaba en su gran poderío económico y de manejo del pensamiento de la mayoría para evitar cualquier peligro de cuestionamiento serio.

Debido a esto, se dio una especie de estancamiento y de rechazo a los avances que se hubieran hecho por el ejercicio del pensamiento libre. Este período trató de juntar de nuevo el mundo en una totalidad, pero no en igualdad de condiciones e importancia como en las sociedades primitivas, sino regida por la religión como reguladora implacable de todo lo que se llegaba a conocer.

La Iglesia tenía que dar el visto bueno a todo lo que se retomaba de los antiguos pensadores y las universidades se desarrollaron, pero reduciendo lo que podían hacer para no ser consideradas como una amenaza. Surgieron pensadores tales como Tomás de Aquino y Ockham que lograron presentar sus avances siendo verdaderos augurios de los tiempos que venían y en los cuales se iba a desarrollar nuevamente la razón científica y un distinto ritmo en el movimiento de las sociedades.

La escolástica se encargó de intentar la síntesis entre la posibilidad de razonar lo real y la promoción de una fe en un mundo aspirado. (...) La escolástica resultó ser, en consecuencia, una corriente representativa, tanto de los tiempos que terminaban como de los que vendrían; un 
movimiento sumergido, al fin y al cabo, en la propia lentitud de los tiempos medievales, que no obstante, consintió ciertos cambios, sin duda importantes, a partir de la posibilidad de que el sujeto pensase y discutiese las más diversas cuestiones. ${ }^{104}$

La estructura feudal se fue transformando poco a poco, las modificaciones que fueron surgiendo cambiaban lentamente la estructura social. Las manufacturas y el comercio dieron gran importancia a las ciudades, donde se concentró el movimiento social. La transición hacia el capitalismo estaba en marcha. El saber también necesitaba cambiar y se fue escapando de las rígidas manos de la Iglesia.

No podemos dejar a un lado el impulso que dieron los viajes y descubrimientos, pues cambiaron la manera de concebir el espacio circundante y el registro del paso del tiempo también ocasionó cambios, pues se dieron cuenta de que el tiempo pasaba de igual manera para todos. Se revisaron los antiguos modelos astronómicos y se comprobó definitivamente la redondez de la tierra. Todos estos nuevos conocimientos obligaron al desarrollo del pensamiento y a adaptar el sistema de la explicación del mundo.

104 Levinas, Marcelo Leonardo. Las imágenes del universo, p. 97. 
El Renacimiento enfrentaba grandes contradicciones pues el movimiento social y económico intenso, no tenía su correspondencia en el pensamiento científico. Según Koyré, "el Renacimiento se encontró sin física y sin ontología..." ${ }^{105}$ por lo que la astrología y la magia se extendieron mucho. La imprenta jugó un papel importantísimo en la movilización de las ideas.

En el Renacimiento también cambió la industria en general gracias a los nuevos inventos y eso incluía principalmente a la industria textil, que trabajó con la nueva rueca de pedal y los telares mecanizados.

La revolución industrial y científica que siguió, desarrolló una libertad para pensar al margen de la autoridad. El modelo copernicano despertó de nuevo el impulso por la investigación y logró por primera vez la aceptación general de un sistema. No sin temor, por la censura de la Iglesia, Copérnico publica su tratado y provoca un sinnúmero de respuestas que ampliaron la actividad del pensamiento de su época. A partir de ahí, se logró avanzar el conocimiento por medio de las matemáticas aunque algunos buscaban que no se contrapusiera con la versión bíblica.

Muchos cálculos astronómicos dieron lugar a descubrimientos muy importantes sobre el movimiento y situación de las estrellas y los astros. Gente como Tycho,

105 En Levinas, Marcelo Leonardo. Las imágenes del universo, p. 117. 
Kepler, Giordano Bruno y Galileo, hicieron avances en la apreciación de las fuerzas que se mueven en el mundo y a través de las que realizamos nuestras actividades, tales como la inercia y la gravedad; también la integración de los cálculos matemáticos con la física permitió sistematizar las explicaciones encontradas. Se estaba construyendo una teoría que aseguraba el conocimiento basado en leyes que abarcaban todos los fenómenos.

Sería ingenuo pensar que la ciencia tiene una existencia autónoma; en realidad depende de la estructura social, de muchos y complejos elementos que la definen y le dicen hacia dónde dirigir su interés. Así ha sido a lo largo de la historia y seguirá existiendo esa dependencia y retroalimentación entre ciencia y sociedad.

Los científicos siguieron investigando y figuras como Descartes, Hooke y Newton, empezaron a construir las bases de lo que sería el proyecto contemporáneo de la ciencia. Se dividieron los fenómenos en sus partes más simples para poder ser estudiados, se intentó hacer coincidir los hechos históricos con los sucesos astronómicos, se inventaron más máquinas que permitían comprobar con exactitud los resultados de los experimentos y repetirlos una y otra vez, la definición de lo real se le dejó a la máquina como intermediaria, de la misma manera que en el ámbito industrial lo artesanal se sustituyó con la producción en masa de la nueva 
maquinaria. Luego de más reflexiones, se pensó que no se podían conocer las causas de todo, puesto que no se podía ir más allá de lo físico. La metafísica, decía Kant, no era ciencia, porque sus objetos de estudio no estaban sujetos a ninguna ley física, sólo se podían pensar.

Por otro lado la razón iba adquiriendo una importancia suprema, se dijo que la ciencia era independiente de la sociedad, y se le dotaba de una neutralidad absoluta en cuanto que pretendía ser totalmente objetiva. La llamada revolución científica reformuló las preguntas que el ser humano se hacía sobre la existencia del mundo y su explicación. Se concentró también en la repetición de fenómenos para comprobar los datos.

Los planetas, lunas y soles ya no eran ligados con ninguna divinidad, se separó definitivamente el mundo social del mundo de la naturaleza y se consideraba a ésta como un mecanismo que funcionaba con la exactitud de una máquina.

Newton había impulsado esta visión que iba a influir en la sociedad. Se enfocó el problema social como algo limitado a lo que podía observarse y por tanto experimentar con él. El origen del ser humano era plenamente natural, creado por instancias que se combinaron en la historia del cosmos y de la tierra. La evolución tuvo como resultado a la humanidad tal y como se conoce, y el individuo fue un producto de esa máquina 
perfecta y que nunca se detiene; la naturaleza. Se parcializó el objeto de estudio, se hicieron fragmentos de la realidad para poder estudiarlos más fácilmente. Así se tenía la impresión de que se podía dominar la naturaleza, al dominar sectores aislados y aplicar la técnica para obtener resultados.

"La máquina es lo característico de la técnica de la modernidad y no representa otra cosa que la especialización de la tarea, el medio para alcanzar un producto específico que simultáneamente viene a crear y a cubrir una necesidad. Cada máquina define un producto; pero también un uso y, en definitiva, una necesidad. Toda esa suma de objetos y usos adquirieron su propio peso y definieron la realidad como producto humano y no divino; o mejor dicho, produjeron una nueva divinidad."106

El ser humano era el nuevo dios, el que podía repetir fenómenos para estudiarlos, inventar máquinas que lo acercaran al proceso que producía la realidad, el que podía modificar algunos resultados de la naturaleza, en fin, el que tenía en sus manos los medios para reproducir el mundo natural en el laboratorio. La razón era la nueva

106 Levinas, Marcelo Leonardo. Las imágenes del universo, p. 288. 
reina que creía poder conocerlo todo, pero no se reparaba en que ya era un todo en pedazos.

Las distintas materias por las que se acercaba el conocimiento a la comprensión del mundo, tales como la biología y la química, eran los pilares del conocimiento del origen de la vida. Ellas explicaban de dónde provenía y cómo se había desarrollado lo que existe en la tierra.

Por vez primera, el hombre se creía que podía conocerlo todo y además, formular leyes que funcionaran en todos los niveles. La arrogancia humana se mostró en todo su esplendor, por considerar al hombre el único que podía conocer y por tanto no necesitaba ninguna ayuda divina; la religión ya no ayudaba para comprender la totalidad del mundo existente.

El método científico surgió como incuestionable poseedor de la verdad, aunque fuera una verdad parcial, limitada a sectores fragmentados $y$ al avance paulatino del conocimiento. Y lo que no se podía conocer se subestimó y se dejó de lado. Pero no es posible vernos desde afuera de lo que somos, tenemos que reconocer que sigue existiendo un sector en el individuo que necesita preguntarse por el origen de todas las cosas más allá de lo que la ciencia tiene para ofrecer.

Cada una de las ciencias, llega a una visión del origen según su objeto de estudio. El sistema de las ciencias pasaría de lo más genérico a lo más particular, y por lo 
tanto encontramos una serie consecutiva de visiones del origen en la ciencia; la visión matemática donde el universo se origina en las relaciones puras; la que da la física, donde hay un origen de la energía; la química, donde el origen es la materia en composición; la biología que es la materia en la composición orgánica y la antropología donde se trata de la materia autosustentable en la vida humana; (sólo podemos hablar del origen dentro del universo humano) y finalmente la sociología donde el estado y la comunidad influyen en todo incluyendo la visión acerca del origen.

Sin embargo, la necesidad de estudiar al individuo y la sociedad desde un punto de vista científico, resultó más complicada de lo que se creía. El objeto de estudio era un sujeto cambiante y se aplicó también la fragmentación para poder estudiar sus complicados componentes. Surgió la sociología como la ciencia que estudiaría rigurosamente al ser humano y a las comunidades formadas por él, dividiéndolo en sectores. Muchos pensadores se opusieron a la esquematización de todo lo existente y formularon sus teorías, pero la sociedad había cambiado; el avance del capitalismo no podía frenarse y la ciencia se veía afectada por ello.

En sentido estricto solamente hay un origen físicocosmológico, sin embargo, cada una de las ciencias fue matizando la importancia del problema del origen y 
planteó que sólo puede entenderse a partir de una secuencia de orígenes intermedios.

En el proceso histórico de las ciencias, con la intención drástica de separarse de las cuestiones religiosas 0 metafísicas, se ha dado una renuncia al problema del origen considerando que el trabajo experimental y especializado resolverá los problemas prácticos de la vida humana sin necesidad de plantearse a cada momento la cuestión general de sus fundamentos.

Aún se tiene la impresión de que la ciencia es un todo ordenado y sistematizado capaz de explicarnos el mundo. La sociedad, por supuesto en la acción de quien tiene el poder, acepta y promueve esta visión, para cumplir con las necesidades que surgen en cada momento y divulga los hallazgos según los intereses del momento. A la mayoría del público común sólo le es permitido enterarse de los descubrimientos que convienen a los grandes intereses y movimientos comerciales.

Se nos ha impuesto el modelo científico con la creencia de que es el único que nos permite conocer la realidad. $Y$ aún así, el pensamiento religioso no ha desaparecido, más aún, la mayoría de la población humana profesa alguna creencia religiosa junto con su fe en la ciencia contemporánea. Esto se tiene que tomar en cuenta, puesto que denota la necesidad que tiene el ser humano de fundar su existencia en algo más poderoso y sabio. 
Algo en nuestro interior nos impide aceptar completamente que todo exista por azar y más aún, que seamos producto de este azar sin ningún objetivo.

Los mitos se van perdiendo y no es porque la sociedad actual sea más racional, sino porque busca sustituirlos con algo que ya ni siquiera contiene la sabiduría de los antiguos, sino que ahora son rituales superficiales que capturan la atención del sujeto común. Por otro lado, la mayoría de los hombres de ciencia siempre tendrán una lucha interior entre la necesidad de que el individuo tenga cierta trascendencia y la postura racional que le demanda su área.

Cada una de las ciencias mencionadas anteriormente dirige su atención al sector que le toca comprender y explicar: por ejemplo, desde la química, la explicación del origen de la vida se encuentra en la combinación de elementos distintos a distintas cantidades y de distinta manera para formar todo lo existente. La química se enfoca en estas relaciones las cuales ha llegado a establecer de manera segura. Se considera que la química es una ciencia cerrada en cuanto sus leyes han quedado como normas a seguir para estudiar la materia. Las ciencias se han alejado de la comprensión del origen del cosmos, y se han concentrado, por medio de diversas disciplinas, a parcelas pequeñísimas del conocimiento del 
origen de la vida, hasta hacerlo una cuestión pragmática o pero aún, política. Se ha perdido el fundamento.

En muchas ocasiones no se quiere investigar para saber, sino para vender, matar, etc. La ciencia se ha visto obligada a servir intereses económicos o políticos y ha tenido que reducir la investigación del origen de la vida. En las ciencias en general se ha renunciado a buscar el origen del universo y sólo la física ha permanecido a la altura.

Sólo la física es la que indaga sobre el origen del universo. Sólo la física se enfrenta al origen absoluto. Por eso nos interesa en este trabajo, porque escapa de estas limitaciones e intenta buscar de nuevo el fundamento.

Especialmente en la cosmología, ha llegado al punto en que encuentra que todo está formado por cuerdas, que son el elemento primordial que conforma el universo. $Y$ por eso es conveniente ver esa relación más de cerca para ver si la física ha encontrado respuestas que tienen coincidencias con lo que tratamos en el capítulo uno respecto al sentido y a la forma como se teje ahora el mundo. 


\subsection{EL TEJIDO COMO MODELO EN AMBOS CAUCES.}

Como ya mencionamos, el tejido, los hilos y sus productos forman un conglomerado que ha estado al lado del ser humano a lo largo de su existencia en el mundo. No sólo elabora redes o telas para vestidos o trajes, sino que, al ser una actividad que transforma por medio del entrelazamiento de diversos elementos, ha servido como metáfora explicativa desde los más antiguos tiempos de las primeras sociedades.

Tejer es una actividad que puede parecer y ser sencilla, pues con cruzar los hilos se obtiene un resultado, pero también puede tener una complejidad sólo descifrada por los expertos en el tema. Desde las sociedades arcaicas el tejido ha permitido a los hombres y a las mujeres, dependiendo de la sociedad de que se trate, pues en África los que tejían eran los hombres y en las sociedades mesoamericanas las mujeres-, interpretar su actividad como un acto de creación.

En la sociedad contemporánea, también las ciencias utilizan dichas metáforas. Podemos ver, por ejemplo en sociología, cuando se habla del entramado social para significar un conjunto de cosas relacionadas entre sí que forman un todo, o a las circunstancias que se entrelazan y 
nos muestran una realidad más complicada que la suma de sus partes. En la biología, los tejidos son conjuntos organizados de células; en psicología las tramas del pensamiento se refieren a la intrincada cantidad de juicios que podemos desarrollar y que dan forma a la personalidad; la trama argumental de cualquier polémica, etc.

Todos estos son ejemplos claros y comunes de nuestra tendencia a relacionar los conceptos pertenecientes al tejido con actividades complejas que contienen orden y estructura y que dan una serie de resultados avanzados.

En los mitos es todavía más claro: se habla específicamente del dios que tejió el mundo, de la trama de la vida, de las cuerdas que conectan a los distintos planos de existencia en que está conformado el universo, de los nudos como formas mágicas de mantener las cosas como se quieren, del hilo que se teje y desteje como una alegoría del tiempo, de la función de algunas entidades para cortar el hilo de la vida, del delicado tejido del universo, de la identificación de la lluvia con los hilos, del sujetarse con cuerdas al centro del mundo como forma de mantenerse dentro de lo sagrado, etc., y de varias otras expresiones que nos dejan ver la facilidad con que el hombre interpreta el tejido y sus implicaciones.

La relación del tejido con lo femenino también es de resaltarse en las tradiciones de muchos pueblos antiguos. 
Los ritos de iniciación masculina son más conocidos por ser la fuerza predominante en muchas sociedades, pero las agrupaciones femeninas tienen también un papel importante y a veces se enfrentan a las fraternidades que hacen los hombres. Mircea Eliade nos presenta varios ritos que se llevaban a cabo antiguamente en Dinamarca:

“...las novicias aprenden canciones y danzas rituales, así como algunas habilidades específicamente femeninas, sobre todo a hilar y tejer. El simbolismo de estas artes es muy significativo. En la fase final de la cultura tendemos a elevarlas al rango de un principio que explique el mundo. La luna "hila" el tiempo y "teje" las vidas humanas. Las diosas del destino son hilanderas. Por una parte, percibimos una relación oculta entre la concepción de las creaciones periódicas del mundo (una mitología lunar) y las ideas de "tiempo" y "destino", y por otra con el trabajo nocturno, con el trabajo femenino, que tiene que realizarse apartado de la luz del sol y casi en secreto. En algunas culturas, cuando finaliza la reclusión de las muchachas continúan reuniéndose en casa de alguna anciana para hilar juntas. La hilatura es un arte peligroso y por ello se lleva a cabo en casas especiales y sólo durante períodos de tiempo particulares y únicamente a ciertas horas. En algunas zonas del mundo se ha 
abandonado la hilatura, quedando incluso olvidada por completo, a causa de su mágico peligro. En Europa persisten creencias similares (por ejemplo, en las hadas germánicas Perchta, Holda, Frau Holle). En algunos lugares —en Japón, por ejemplo- podemos hallar todavía el recuerdo mitológico de una tensión permanente, incluso de un conflicto, entre los grupos de las muchachas hilanderas y las sociedades secretas masculinas. Por la noche, los hombres y sus dioses atacan a las hilanderas y destruyen no sólo su trabajo, sino también sus lanzaderas y telares." ${ }^{107}$

Ese trabajo secreto representa en esas culturas algo de lo que la mujer es depositaria y tiene algo de magia por cuanto está relacionado con los dioses. Es un saber que compite con el saber masculino y al que los hombres temen pues escapa de su área de control. Nos viene a la mente el temor de ciertas épocas hacia la mujer por considerarla poseedora de fuerzas que pueden ser peligrosas, como en el caso de las hechiceras a quienes se les temía y quería destruir por suponer que tenían pacto con el diablo, la fuerza maligna que se oponía a los establecido.

El significado del tejido como productor de fuerzas que son capaces de crear y de establecer contacto con otros

${ }^{107}$ Eliade, Mircea. Nacimiento y renacimiento, p. 76. 
planos, además de ser la metáfora de conexión entre todo lo existente, es una constante a lo largo de la historia.

El simbolismo de la cuerda como comunicante entre el plano celeste y el de los humanos, es un concepto recurrente en varias culturas. También es significativa como el cordón umbilical que une al nuevo ser con la madre y fuente de vida.

Entre los mesoamericanos, el árbol que es el eje y centro del mundo, conecta los diferentes niveles de lo que existe. Y a él se amarra el telar como copartícipe de las conexiones que simboliza y como una extensión de las energías sagradas hacia lo que se teje. Además, los hilos simbolizan la lluvia que cae sobre la tierra y hace surgir la vida sobre la tierra.

En otras creencias de la India, la cuerda simboliza la conexión del plano terrestre con el plano celestial y puede el ser humano, en ciertas condiciones proporcionadas por el ritual, subir por ella y comunicarse con los dioses.

El mito griego de las Moiras es un ejemplo exacto de cómo la metáfora de los hilos y la vida funciona para ilustrar la manera en que los dioses pueden tejer o cortar el ciclo de la vida. El tejido funciona muy bien como imagen para describir el destino; sobre la estructura puesta por los dioses, los hilos van tramando en cualquier dirección, tal y como los acontecimientos de la vida se 
suceden unos a otros y se conectan de maneras inesperadas.

En varias tradiciones, el tejido, los hilos, las cuerdas, tienen ese contenido de creación y orden, del caos a la vida estructurada, de la nada a la plena existencia, de lo incomprensible a lo visible, de lo informe a la multiplicidad de formas, del aislamiento a la conexión, etc., y hemos crecido siendo humanos comprendiendo que el tejido y sus elementos son inseparables del ser humano y sus culturas. 


\section{CAPITULO 3}

\section{El tejido cósmico en la ciencia contemporánea}

\subsection{Las tramas en la ciencia y en la historia}

La ciencia siempre ha puesto en jaque las creencias humanas sobre la creación, el origen de lo que existe y el funcionamiento de las cosas en la naturaleza. Tanto en las creencias míticas y religiosas que usualmente habían dado explicación sobre el origen del ser humano, como en el desarrollo del conocimiento científico, trae la ciencia cambios en la percepción de lo que nos rodea.

Desde el momento en que la ciencia demostró que una ecuación matemática podía explicar y funcionar para los hechos naturales, trajo como consecuencia que el individuo mismo fuera un hecho natural en vez de una creación divina; sin la importancia que le daba el dios, el hombre quedaba sujeto a las leyes de la naturaleza. Descubrir, por otro lado, que la tierra no era plana, ocasionó una ruptura con todo el sistema de creencias, porque lo que implicaba más allá del sólo hecho per se, contradecía los conceptos que había sostenido hasta ese momento el orden social y humano. 
Las repercusiones de los descubrimientos científicos son siempre primero percibidas por los dirigentes de los sistemas de creencias y luego llegan al público en general. Actualmente, tanto los líderes de los gobiernos, como los dirigentes de las jerarquías religiosas, procuran conocer el avance científico para adaptar los nuevos descubrimientos de manera que vayan acomodándose al gobierno que ejercen sobre la gente, para lograr que la estructura se mantenga intacta.

El desarrollo de la ciencia en la historia, ha pasado por muchas etapas y se han superado las teorías incorrectas, incluso hubo periodos en los que causó cismas importantes, pero siempre el genio de los científicos se destacaba al imaginar soluciones o explicaciones para los hechos naturales.

Uno de los momentos importantes fue cuando el instrumento para medir se constituyó en el determinante de la realidad, de tal manera que la subjetividad quedó hecha a un lado. Las cualidades de los fenómenos podían ser determinadas de manera segura para todos, sin depender de la sensación o la apreciación. Pero esto promovió una actitud donde se tendía a minimizar o ignorar lo que no se podía medir, haciendo que la realidad relegara su inmensa variedad ante la subordinación al instrumento. 
La matemática se erigió como la depositaria de la verdad y como dice algún autor, se tiende a confundir la verdad con el poder, por lo que se hizo creer a todos que lo único cierto estaba en lo susceptible a medición. Ya no se dependía de los sentidos, sino de los datos que se obtenían a través del instrumento, aunque éste obviara muchos elementos adyacentes al fenómeno.

Con Newton la ciencia hace que la totalidad de las cosas puedan investigarse y responderse ya no con dioses y sus acciones, sino desde las cosas mismas. Descubrir que los planetas no giran alrededor de la tierra cambió tremendamente la percepción del lugar donde vive el ser humano y el cual había sido considerado el centro del universo. $\mathrm{Y}$ así pareciera que la importancia humana, construida por mitos y religiones, se veía cada vez más disminuida.

El impacto que causan los descubrimientos hechos por la ciencia sobre las creencias religiosas es tremendo, pero como no se tiene la certeza de todas las cosas, sino que cierta fórmula o ley se cumple para un sector de lo existente y además no se tienen todas las respuestas, tanto en la fe como en la ciencia sigue habiendo misterio. Aunque la extrema variedad de fenómenos que existen en lo que nos rodea hace difícil concebir que todo esté perfectamente calculado, nos enfrentamos a un número 
gigante de probabilidades y todas ellas se presentan ante el hombre de una manera no tan rígida.

La mecánica de Newton permitió saber qué es lo que pasaba con los sistemas estelares sin considerar que eran obra de los dioses. Las matemáticas podían dar cuenta no sólo de lo que pasa en el mundo que se habita, sino en los planetas y el espacio.

La revolución newtoniana “...como cuestión de principio continúa teniendo unas implicaciones sobrecogedoras. La antigua concepción del cosmos como sociedad de temperamentos que coexisten en equilibrio deja paso a la imagen inanimada e incluso estéril del universo mecánico. Inevitablemente, los descubrimientos de Newton parecen relegar el mundo entero a la condición de mecanismo que marcha inexorable y sistemáticamente adelante hacia un destino preestablecido, donde cada átomo corre siguiendo una trayectoria retorcida pero legislada hasta alcanzar un destino inalterable.

Finalmente este cambio de perspectiva tuvo su impacto sobre la religión. La primitiva idea cristiana de un Dios activo que participaba de cerca en los negocios mundanos, supervisando los acontecimientos, desde la concepción de los niños hasta las fases de la Luna, fue sustituida por una idea más lejana de Dios como iniciador del movimiento cósmico, que observa pasivamente el 
desenvolvimiento de su creación según sus propias leyes matemáticas." ${ }^{108}$

Realmente la ciencia ha avanzado para atisbar la posibilidad de varios universos más allá del universo determinado y mecánico a que pudiera conducir el razonamiento de Newton.

Se ha visto que la realidad funciona ante nuestros ojos muchas veces como aleatoria, pero si se aplica la ciencia a un cierto fenómeno, es posible desentrañar las condiciones y predecir el futuro de ese fenómeno en particular. Pero cuando se desarrolló la llamada teoría cuántica, se vio que no todo se podía explicar según las leyes que formuló Newton. Se encontró que cuando se estudiaban los átomos, digamos en su camino de A a B, los átomos podían tomar variados caminos, no necesariamente el más corto y entonces se abría un mundo de probabilidades.

"Resumiendo los rasgos más significativos de la revolución cuántica: encontramos que las leyes rígidas del movimiento son el realidad un mito. La materia tiene permitido vagar errante de manera más o menos aleatoria, sometiéndose a ciertas presiones, como es la aversión a hacer demasiado esfuerzo. El caos absoluto, pues, se elude porque

108 Paul Davis. Otros mundos, p. 8. 
la materia es perezosa al mismo tiempo que indisciplinada, de modo que, en un determinado sentido, el universo elude la total desintegración gracias a la indolencia inherente a la naturaleza. Si bien no es posible hacer ninguna afirmación taxativa, sobre ningún movimiento concreto, determinadas trayectorias son más probables que otras, de tal forma que estadísticamente podemos predecir con exactitud cómo se comportará una gran masa de sistemas similares. Aunque estos extraños rasgos solo resultan sobresalientes a escala atómica, es evidente que el universo no es, a fin de cuentas, un mecanismo de relojería cuyo futuro esté absolutamente determinado. La incertidumbre es una propiedad inherente de la materia". 109

Esto nos lleva a un mejor entendimiento del mundo aunque parece estar bajo una contradicción: las cosas parece que suceden por azar, pero en realidad hay un orden oculto, que la ciencia contemporánea está intentando encontrar.

Las preguntas sobre el origen de la vida y sobre la realidad misma siguen formulándose continuamente en la ciencia contemporánea. De las ciencias que estudian el origen, la física es la disciplina que está a la vanguardia de los descubrimientos que permiten tener una idea más

109 Paul Davis. Otros mundos, p. 19. 
precisa acerca del mundo en que vivimos, del orden que existe tanto en la dimensión de las cosas grandes, enormes, como en la dimensión diminuta, subatómica; ambos campos son imposibles de captar a simple vista, pero los instrumentos desarrollados por la tecnología permiten una aproximación a ellos.

Sin embargo, los mismos físicos nos demuestran que el conocimiento matemático y sus ecuaciones son las únicas maneras de las que podemos obtener la comprobación de ciertos fenómenos o realidades que explican cómo funciona el universo. Son éstas dimensiones y campos del conocimiento, extrañas realidades a las que los teóricos se tienen que enfrentar para irlas comprobando poco a poco, desde diferentes ángulos alrededor del mundo, por lo que se han logrado avances impresionantes en los últimos cincuenta años.

Las posibilidades están ante los ojos de los científicos contemporáneos, deslindadas ahora del conocimiento mítico de la antigüedad y de los conceptos religiosos que se profesan, pero con el mismo interés por conocer un poco más, por explicarse las razones de la existencia, y tratando de que los demás puedan ver de una manera más simple los complicados procesos por los que se acercan al planteamiento y la resolución de problemas.

La física también tiene historia, pues ha ido de un planteamiento a otro para tratar de exponer la verdad. La 
rama de la física en la cual se han podido hacer más progresos es la cosmología, la ciencia que estudia el origen y la evolución del cosmos. La cosmología ha fascinado a los habitantes de todas las épocas, pues todos hemos tratado a lo largo del tiempo de explicarnos el origen, el nacimiento de todo lo existente.

Y de la observación por medio de las máquinas y los cálculos matemáticos sobre lo que existe surgió la teoría que es la más aceptada actualmente acerca de cómo empezó el universo: el Big Bang. En la década de los setentas, se acumuló la información y se logró demostrar que el Big Bang había sucedido y explicaba de manera satisfactoria el desarrollo del cosmos.

Einstein ya había propuesto una nueva teoría que cambiaba la concepción y la función del espacio y el tiempo.

"Entre las predicciones más espectaculares de la teoría se cuenta la existencia de antimateria y los viajes en el tiempo, la elasticidad del espacio y del tiempo, la equivalencia de la masa y la energía y la aniquilación de la materia. Como ampliación de su trabajo de 1905, Einstein publicó en 1915 la llamada Teoría general de la relatividad. Aunque no $\tan$ bien fundada experimentalmente, sus predicciones son igual de fantásticas: espacio y tiempo curvos, agujeros negros, la posibilidad de un universo finito pero ilimitado e incluso la 
posibilidad de que el tiempo y el espacio se disuelvan en la inexistencia." 110

Las consecuencias de estas teorías, son para nuestro pensamiento cotidiano un poco increíbles, pues de acuerdo con ellas podríamos afirmar que el futuro y el pasado son solamente cosa de percepción, pues lo que para una persona puede ser pasado, desde la perspectiva de otra puede ser presente, todo dependería del lugar en el que esté situado el espectador con respecto a la velocidad de la luz, al tiempo y al espacio. Pero afortunadamente no hay nada que pueda viajar más rápido que la luz, por lo que entonces no está en peligro la coherencia del universo.

La teoría de Einstein explicaba con sus ecuaciones de la relatividad general los objetos grandes y masivos, pero había un problema, y era que esos planteamientos no funcionaban para los objetos pequeños. Los físicos sabían que para poder aproximarse a éstos últimos se necesitaba la intervención de la mecánica cuántica cuyas ecuaciones trabajaban bien sobre los elementos minúsculos que conforman el mundo físico. El gran problema era que cuando se trataban de juntar las ecuaciones de ambas partes de la física, no funcionaban y no había modo de encontrar la solución.

110 Paul Davis. Otros mundos., p. 21. 
Se necesitaba entonces una teoría que unificara dichos aspectos, alguna que permitiera entender completamente el espacio y el tiempo y por lo tanto encontrar ecuaciones que puedan acercarse a los primeros momentos del universo. Lo que se esperaba encontrar era una teoría que abarcara todas las leyes de la naturaleza.

Durante todo el siglo XX los investigadores intentaron unir la mecánica cuántica y la relatividad general generando lo que se conoce como la teoría de las supercuerdas.

“...según la teoría de supercuerdas, cada partícula está compuesta de un minúsculo filamento de energía, unos cien trillones de veces más pequeños que un simple núcleo atómico (un tamaño mucho más pequeño que lo que actualmente podemos sondear), que tiene la forma de una pequeña cuerda. E igual que una cuerda de violín puede vibrar con pautas diferentes, cada una de las cuales produce un tono musical diferente, los filamentos de la teoría de supercuerdas también pueden vibrar con pautas diferentes. Estas vibraciones, sin embargo, no producen notas musicales diferentes; lo que la teoría afirma, y esto es extraordinario, es que producen diferentes propiedades de partículas. (...) Y por si esto no fuera suficiente, la teoría de supercuerdas ha revelado la anchura necesaria 
para hilvanar todas las fuerzas de la Naturaleza y toda la materia en el mismo tapiz teórico."111

Lo que la ciencia propone también, como necesario para que funcione en su explicación del mundo, es que no sólo existen las tres dimensiones que conocemos y el tiempo, sino que requiere nueve dimensiones espaciales y una dimensión temporal. Por este motivo, esta teoría se ha presentado como el hallazgo más importante, ya que nos dice que sólo hemos trabajado sobre un sector muy pequeño de lo que en realidad estructura el universo.

Aunque tiene algunos problemas para demostrarse experimentalmente, la teoría de las supercuerdas ha resultado ser una fuente enorme de conocimientos y por medio de ella la física ha logrado los avances tan impresionantes que ha hecho en su comprensión de lo existente. Como siempre, el ser humano ha encontrado dicho conocimiento sumergiéndose en los misterios del universo, utilizando la observación pero también la imaginación, estas dos facultades han sido puestas en práctica desde las sociedades más rudimentarias hasta dentro de la física más contemporánea.

El espacio y el tiempo son la urdimbre y la trama de todo el universo, del mundo en que vivimos. Hasta Einstein, los

111 Green, Brian. El tejido del Cosmos, pp. 35 y 36. 
descubrimientos habían llevado a concebir que la luz se movía en el espacio, y se calculó su velocidad aunque se pensaba que necesitaba un medio para moverse. En su artículo "Sobre la electrodinámica de los cuerpos en movimiento" de 1905, Einstein habló sobre un problema que venía dando dolor de cabeza a los científicos de la época. Afirmaban que si la luz se movía en el espacio, entonces debía existir un medio por el cual se transmitiera dicha electricidad y le llamaban éter, pero no se había podido probar su existencia.

Einstein declaró que las ecuaciones para demostrar la existencia de dicho éter fallaban porque éste no existía. Entonces no existía un patrón de reposo para interpretar la velocidad, que es como comúnmente se interpretan las velocidades. Y la genialidad de Einstein fue declarar que la velocidad de la luz era de 1.080 millones de kilómetros con respecto a nada y a todo y además siempre es constante.

Esto desafiaba al sentido común, pues se supone que si alguien corre detrás de la luz, desde su perspectiva se verá que va más lenta, y si alguien corre hacia la luz, se verá como si se aproximara más rápido. Pero la luz, decía Einstein, se comporta siempre de la misma manera, aunque eso no tenga sentido para nuestro pensamiento común, y así se resolvieron las ecuaciones que se habían 
planteado sobre el comportamiento de la electricidad. Afirmó la teoría de la relatividad:

\begin{abstract}
"Espacio y tiempo se ajustan de una manera que se compensa exactamente, de modo que las observaciones de la velocidad de la luz den el mismo resultado, independientemente de la velocidad del observador."112
\end{abstract}

No nos resulta raro que los objetos se muevan a través del espacio, pues esa es la conformación de nuestra cotidianeidad, pero también debemos tener en cuenta que todo se mueve a través del tiempo también, y esa combinación de moverse en el espacio y el tiempo es lo que nos lleva a las afirmaciones que planteó Einstein y las cuales parecerían que contradicen a lo que estamos acostumbrados, y por eso surgió una ley de la relatividad especial que dice:

la velocidad combinada del movimiento de cualquier objeto a través del espacio y su movimiento a través del tiempo es siempre exactamente igual a la velocidad de la luz." ${ }^{113}$

Eso nos provoca incomodidad, pues estamos acostumbrados a pensar que nada se mueve a la

112 Green, Brian. El tejido del Cosmos, p. 73.

113 Ibid. p. 75. 
velocidad de la luz, pero eso únicamente es cierto cuando consideramos el espacio, y aquello se refiere a la velocidad combinada en el espacio y en el tiempo, lo cual, según descubrió Einstein, es lo que permite dichos eventos que en una vista simple nos pudieran parecer sin sentido.

Hubo experimentos en la década de los setentas, que demostraron indudablemente que Einstein tenía razón. Se puso un reloj súper exacto en un avión que dio la vuelta al mundo y a su regreso se comparó con el reloj que se había quedado en tierra y se comprobó que había transcurrido menos tiempo en el reloj que se encontraba en el avión, en fracciones de cienmilésimas de millonésimas de segundo; ${ }^{114}$ y eso le daba la razón a Einstein. Demostraba, ante el escándalo de los científicos de la época, que el tiempo y el espacio son elásticos y que debido a eso los fenómenos dependían del punto de vista y situación del espectador.

La teoría de la relatividad de Einstein no afirma que todo es relativo, solamente que algunas cosas son relativas. Por ejemplo, introdujo el concepto del espaciotiempo absoluto. Una región del espacio, considerada durante un intervalo de tiempo se denomina una región de espaciotiempo. ${ }^{115}$

\footnotetext{
114 Green, Brian. El tejido del Cosmos, p. 76

115 Ibidem, p.80.
} 
Ahora bien, antes se consideraba que todos teníamos la misma visión de lo que ocurría en un tramo determinado de tiempo en el mismo lugar, pero resulta que como el tiempo transcurre diferente en cada uno de nosotros, sujetos en movimiento, entonces la percepción de lo que pasa en ese mismo trozo de espaciotiempo, puede variar para los dos observadores. Esto se conoce como la relatividad de la simultaneidad. $Y$ ambas percepciones son igual de válidas.

El espacio absoluto no existe, el tiempo absoluto no existe, pero el espaciotiempo absoluto sí que existe, según afirma Einstein. Los físicos ya no ven las cosas sólo en el tiempo o sólo en el espacio, sino extendidas en el espaciotiempo. Es en esa región conceptual que se mueve todo lo que no varía. Por ejemplo, una línea recta siempre será una línea recta, no importa si varía el lugar o el tiempo en la que esté. En el espaciotiempo absoluto, siempre permanecerá invariable y esto proporciona una referencia definitiva para el movimiento. La electricidad se mueve con respecto a este espaciotiempo absoluto.

Esto a pesar de que puede sonar muy simple, es lo que permitió el avance de la física y nuestra comprensión de las leyes del universo pues permite explicar por qué las ecuaciones del tiempo y del espacio de repente no funcionaban para otras variables. Pero una vez establecido el espaciotiempo absoluto, ya se pueden 
mover los físicos para aplicar las ecuaciones que demuestran sucesos relativos y absolutos. El elemento más importante que introdujo la relatividad, es la subjetividad, por lo que el sujeto observador vuelve a tener un papel importante dentro del funcionamiento del cosmos, pero a otro nivel.

Con las reglas de Newton se explicaban los fenómenos a partir de la cotidianeidad, pero desde la teoría de la relatividad, se puede explicar todo más simple y elegantemente, afirman los físicos. En la física actual, las teorías parece que contradicen el sentido común, salen de todas las reglas que suponemos rigen el funcionamiento de las cosas que conocemos.

"...la nueva física nos dice que un objeto en movimiento se contrae en dirección a su movimiento. Un reloj en movimiento avanza más despacio que uno en reposo. La masa y la energía pueden ser intercambiables. Los constituyentes básicos de la materia tienen ambas características, de onda y de partícula, la llamada "dualidad onda-partícula". El acto de observar un sistema físico influye en su comportamiento. La presencia de materia puede influir sobre la geometría del espacio y alterar el flujo del tiempo. No podemos decir con certeza si algo está aquí o allá -sólo expresar la probabilidad de que eso está aquí o allá. Esto significa que debemos 
abandonar una estricta descripción determinista de los fenómenos naturales, por lo menos en la escala de las moléculas y los átomos y depender de las probabilidades. $Y$ hay más, mucho más."116

Es decir, que lo que damos por hecho, por normas inmutables en nuestra experiencia cotidiana, cambia radicalmente en cuanto nos acercamos al mundo de la física moderna. $Y$ he ahí lo rico de dicha experiencia, pues al abrir la mente a posibilidades que a primera vista parecerían absurdas o completamente ajenas a la lógica cotidiana, comienzan a percibirse las relaciones entre el mundo de lo infinitamente grande y lo infinitamente pequeño.

La física contemporánea ha descubierto que esos mundos no se mueven según lo normal para nuestros sentidos 0 para las concepciones que tenemos del mundo que nos rodea. No ha sido fácil, es necesario que nuestro intelecto trabaje diligentemente para superar los límites que nos impone la realidad cotidiana. Lo único que se hace es calcular probabilidades, en vez de predecir lo que va a resultar de un experimento.

Esto ha llevado a varias generaciones de físicos a dudar, porque son descubrimientos que no concuerdan con la lógica a la que estamos acostumbrados, ni con la certeza

116 Gleiser, Marcelo. (Op. cit.) p. 191. 
que se suponía daba la ciencia. Varios escritos han sido dejados a un lado por cuanto parecieran locuras 0 grandes absurdos, pero una vez que se avanza en algún descubrimiento se generan líneas a partir de esos escritos que son seguidas por muchos físicos en varias partes del mundo.

Incluso ellos mismos han tenido que luchar contra sus propias creencias, pues sus hallazgos desafiaban toda la postura clásica de cómo se concebían las cosas en el universo. Así, tuvieron que abrir su pensamiento a datos que surgían y que no concordaban o que muchas veces contradecían lo que estaba establecido.

De esa manera la cosmología, que había sido dominio exclusivo de la religión o de debates que pretendían basarse en postulados científicos sin lograrlo, llegó a ser por fin, la ciencia que explicaba el universo.

Y los científicos van buscando poco a poco respuestas a las mismas preguntas que se han hecho los humanos durante siglos, y en todas las culturas a través de los mitos, de la religión, de la ciencia. Preguntas que nos conforman como humanos y cuya búsqueda define nuestra existencia en el mundo y en la sociedad en que vivimos; regresamos pues a las cuestiones que nos inquietan, a lo que como humanos queremos entender, ya sea desde la creación de imágenes para construir mitos, dioses o la formulación de postulados científicos y todos 
esos puntos de partida son válidos en cuanto satisfacen nuestra necesidad de saber de dónde venimos y en qué punto del universo nos ubicamos.

"Los científicos modelan lo desconocido con no mucho más que la autoconsistencia lógica y los principios físicos generales como guía, mientras los hacedores de mitos tratan de construir imágenes de aquello que no tiene imagen. Los resultados muestran una hermosa, aunque limitada universalidad del pensamiento humano cuando se aproxima a la comprensión de cómo el "Absoluto" se deviene en relativo, y cómo el "Uno se convierte en muchos".

Los modelos científicos de la creación o modelos cosmológicos en cierto sentido no pueden sino repetir algunos de los temas de los mitos de creación. El mundo siempre ha sido o aparecido en cierto momento del pasado como algo creado del caos o la nada, o, quién sabe, para siempre creado y destruido en una danza de fuego y hielo. Hay sólo un número finito de respuestas posibles, las cuales han sido visitadas independientemente por la imaginación científica o religiosa. Quizá aún más importantes que las respuestas son las preguntas, pues revelan claramente lo que significa ser humano..."117

117 Gleiser, Marcelo. (Op. cit.), p. 246. (Tr. Eugenia Yllades). 
Y Gleiser seguidamente cita a Milán Kundera, quien dice que al preguntarnos algo a lo que no podemos dar respuesta, es donde se ven claramente los límites de la naturaleza humana.

En la historia, la pregunta sobre el origen había tenido una respuesta que lo mostraba como algo estático en las religiones, pero llegó un momento en que la ciencia logró percibir su dinamismo, la complejidad de su movimiento, y la riqueza de sus evoluciones, lo que nos recuerda los mitos más antiguos por cuanto el movimiento de las fuerzas naturales, e inspiró a los científicos quienes siguen intentando descifrar su estructura. Cada vez hay más modelos que surgen de los descubrimientos y cada modelo muestra la riqueza del universo y del pensamiento humano para describirlo.

Se legitima el cruce entre los linderos del conocimiento y la creencia cuando se utilizan para encontrar senderos y complementar los postulados. La ciencia también a veces crea confusión. Hay ocasiones en que dos teorías contrarias se plantean $y$ al tener postulados correctamente sustentados, convencen, cada una por su parte, a varios científicos de que se tiene la razón y esto dura hasta que se descubre algo que invalida o subordina a uno de los dos planteamientos.

$Y$ eso no necesariamente es malo, aunque cause cierta confusión, ya que el estudio en ambos sentidos, 
enriquece el campo del conocimiento humano. Diferentes hilos de distintas texturas y en diferentes direcciones logran que el tapiz que se teje sea mucho más expresivo y rico. Pueden pasar siglos de especulación, pero finalmente se avanza y se descubre la ruta. El universo, siempre transformándose y en movimiento, nos pone ante grandes retos que el pensamiento humano, combinando objetividad y subjetividad, tiene que resolver. $Y$ desde los antiguos humanos constructores de mitos, se puede ver la insaciable curiosidad humana que sigue innumerables senderos para explicarse lo que nos rodea. Las respuestas son variadas y siempre se fuerzan los límites más allá de lo que aparentemente ya se comprende.

En la siguiente gráfica se puede ver el esquema que construye Marcelo Gleiser para clasificar los modelos cosmogónicos manejados por la ciencia. A la pregunta sobre si existe un inicio del universo, se le pueden dar dos respuestas, una afirmativa y otra negativa. Si se responde negativamente, entonces quedarían dos posibilidades: la de que toda la existencia es eterna, está ahí desde siempre y para siempre con solo transformaciones a su interior pero sin haber tenido un comienzo, y la de que el universo es rítmico por lo que habría un avance y luego un retroceso, pero siempre existiría, no se diluye en la nada ni aparece espontáneamente. 
$\mathrm{Si}$ se pretende responder a la pregunta de manera positiva, Gleiser dice que se han planteado tres posibilidades: la primera, que la creación partió de algo, no se puede aún conocer qué, pero habría algo a partir de lo cual se formaría todo lo que existe; la segunda posibilidad sería que existía un caos primigenio del cual surgió un orden que ha llevado a la existencia de todo el universo tal y como lo conocemos; la tercera sería que el universo surgió de la nada, apareció repentinamente y comenzaron a crearse todos los elementos que conforman el cosmos. 


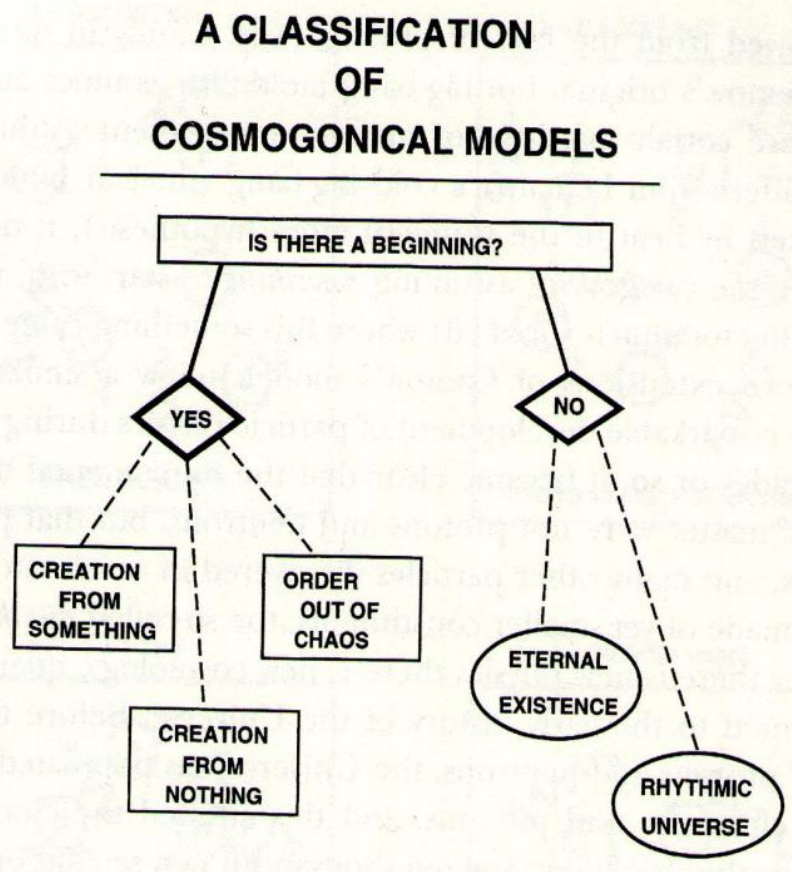

Different scientific answers to "the Question"

Como puede verse, tampoco en la ciencia tenemos la seguridad absoluta de conocer de dónde surgimos. Los esfuerzos de los científicos han hecho grandes cosas y esperamos que los planteamientos que nos vayan aclarando el panorama sigan surgiendo, pero por lo pronto, sólo podemos quedarnos con las posibilidades.

118 Gleiser, Marcelo. The Dancing Universe, p. 303. 
Con el avance de la ciencia en estas últimas décadas, los científicos han tenido que enfrentarse a problemas que nunca estuvieron dentro de su área. La trama se complica. El problema de la conciencia -respecto a que un experimento cambia cuando hay un observador-, pone a los físicos ante una cuestión que consideran filosófica y algunos tratan de evadir el tema diciendo que la conciencia es únicamente la actividad que realiza el cerebro.

Y así, avanzando los argumentos de los últimos descubrimientos y las teorías de la física con sus planteamientos, es necesario pensar acerca del tema del azar o de la determinación de la existencia. ¿Qué papel tiene el ser humano en la existencia del cosmos? Somos los observadores y parece ser que también los únicos que tenemos conciencia de la existencia del universo; nuestros instrumentos demuestran cosas, nos acercan a comprender más verídicamente lo que existe, pero si no existiéramos los humanos, entonces no habría ni percepciones ni mediciones ni exploración, por lo que de ahí se deduce que jugamos un papel muy importante, no solamente como una parte orgánica e incidental del universo, sino como los poseedores de una conciencia para entender el mundo.

Esto regresa al individuo su importancia en el universo, lo saca de su fría clasificación como otra forma de vida 
únicamente. El humano es el observador del universo. Normalmente, la ciencia no tiene en cuenta esa postura del individuo, pues trata de dirigirse a la realidad objetiva, pero a estas alturas del avance de la ciencia, sobre todo en la física, no es posible dejar de lado al creador de esos aparatos, pues conforma ese punto desde donde se puede ver el universo y es entonces cuando ejercemos nuestro desempeño dentro del cosmos. El observador es importante por cuanto su presencia hace variar la realidad.

La teoría cuántica nos lo ha demostrado pues “...el experimentador al elegir entre cierto número de magnitudes observables e incompatibles cuál de ellas medir, cambia las alternativas cuánticas que se ofrecen, si bien no puede imponer una opción."119

La física ha tenido que enfrentar los problemas del azar y la determinación en cuanto a los experimentos que se han hecho con el comportamiento de las partículas, y las consecuencias afectaron la manera como se concebía el ser humano, la conciencia, la elección, el azar, el tiempo y por lo tanto el pasado, el presente y el futuro, reflexiones sobre temas que se habían dejado a la filosofía, pero que se tuvieron que traer a la mesa de la ciencia.

119 Davis, Paul. Otros mundos, p. 192. 
Desde los mitos antiguos, -que a despecho de muchos no pueden considerarse sólo mentiras o pura imaginación ya que se construyeron a partir de la observación de la naturaleza y el cielo-, hasta la cosmología contemporánea, el ser humano ha recorrido muchos caminos en los que ha puesto su creatividad para avanzar en el entendimiento del mundo, y a pesar de los avances, no podemos dejar de pensar que lo que ahora consideramos leyes y cálculos exactos, en el futuro se descubrirá que no son sino esbozos o partes que no describían lo que realmente era, porque así como hemos superado los conocimientos de los científicos antiguos, en el futuro se superará lo que actualmente existe.

Y las culturas antiguas, así como los primeros hombres de ciencia, han jugado su parte para contribuir al conocimiento del mundo que nos rodea. Sin ellos no podría haber habido avances, el ser humano siempre busca respuestas a las preguntas y utiliza todos los recursos que tiene disponibles, tanto exteriormente como en el fondo de nuestro cerebro para poder moverse en este cosmos en el que habita.

Cada comunidad humana, por más primitiva que nos parezca ha mostrado su percepción del mundo y ha puesto en sus creencias los hallazgos encontrados. Desde la mitología arcaica, donde el mundo imaginario se combinaba con el funcionamiento real del entorno cercano 
y lejano, hasta la ciencia contemporánea en la cual son verdaderamente pocos los que se ocupan del estudio del universo, los humanos nos encontramos inmersos en este juego del pensamiento que quiere y necesita comprender cómo un ente conciente tiene qué desempeñarse entre las fuerzas que en un momento pueden aniquilarlo.

Normalmente la mayoría preferimos concentrarnos en la vida cotidiana sin pensar en lo involucrados que están los láseres, las energías, las partículas, las fuerzas gravitatorias, el azar, la conciencia, etc.; para que esa vida funcione, todos tenemos nuestro papel, ya sea insignificante o grandioso en la comprensión de esta maravilla que nos rodea.

Tanto la relatividad como la teoría cuántica muestran la necesidad de ver el mundo como un todo donde cada elemento, incluyendo al ser humano, establecen relaciones; es un tapiz -y así lo describen los físicos-, donde está entrecruzado todo lo que existe y la teoría de las supercuerdas intenta explicar cómo es que se tejió con tanta maravilla. 


\subsection{La teoría de las supercuerdas}

La investigación de la física contemporánea está desarrollando teorías que transgreden los planteamientos estables de la ciencia. Ha entrado en una fase donde los hallazgos y los planteamientos acerca de cómo funciona la realidad y todo lo que vemos, parecieran salirse de la rigurosidad a la que la ciencia había estado siempre aferrada.

La teoría tan buscada por Einstein de unificar las áreas que explican tanto lo grande como lo pequeño y las diferentes maneras en que la materia se comporta en esos dos ámbitos, está siendo desarrollada por los estudiosos. Los físicos trabajan en partes reducidas del problema general y gracias a esto se puede avanzar en el descubrimiento de variables que definen cada una de dichas partes, pero también debido a eso algunas veces encuentran dificultades para explicar sus fórmulas. Otras veces, gracias al contacto con los colegas, descubren que lo que resulta del estudio de una parte del problema, es la respuesta para otra parte distinta.

Aunque por esa fragmentación la teoría carece de un principio que la defina, los avances han sido tan exitosos 
que animan a seguir por el mismo sendero aún con las posibles carencias. Los cosmólogos se dedican a estudiar la cuestión del origen del universo, el problema más peliagudo; los astrónomos se acomodan en el sistema solar; los físicos nucleares se dedican a ver qué sucede con el átomo y sus comportamientos y relaciones; los físicos de partículas investigan hasta dónde pueden llegar descubriendo cosas cien millones de veces más diminutas que el átomo.

La mundialización que ha tenido lugar en las últimas décadas, ha servido para que se compartan conocimientos y que se den avances mayores por cuanto se relacionan muchas disciplinas. Así sucedió con la teoría de cuerdas: la multitud de partículas descubiertas en el universo, complicaba la situación, pero la teoría de las supercuerdas parecía proporcionar una manera de explicar esa complejidad. Esta Teoría de las cuerdas fue presentada por Michael Green y John Schwarz, y aunque todo está en fase hipotética, ha permitido por medio de cálculos matemáticos avanzar y proponer nuevos conceptos y dimensiones que expliquen los hallazgos teóricos. Además, se ha encontrado una unidad que no se contradice y tiene coherencia lógica cuando se van añadiendo dimensiones y unificación de las fuerzas que se conocen. 
Cuerdas, branas, dimensiones y otros conceptos que proponen los físicos aparecen constantemente en la literatura científica actual, constituyendo el fundamento de las teorías que se proponen la búsqueda de una única teoría que logre explicar las cuatro fuerzas de la naturaleza, la gravitatoria, la electromagnética, la nuclear fuerte y la débil, como casos particulares de una sola fuerza unificada. He utilizado dos veces la palabra proponen, porque todos los conceptos todavía no confirmados en la práctica, sólo son proposiciones, así como las teorías aún las más lógicamente estructuradas, sólo son hipótesis para tratar de irse acercando a lo que llamamos realidad. La historia de la ciencia ha mostrado, y de qué manera, que mediante esa metodología, la ciencia ha marchado $y$ sigue marchando exitosamente. ${ }^{120}$

Los físicos teóricos no se amilanan ante la imposibilidad de experimentar, porque comprenden que aún no tenemos la tecnología suficiente para construir máquinas que demuestren en la práctica lo que han avanzado en la teoría.

La explicación científica intenta dar la explicación del origen del universo, pero a veces me parece que resulta

120 Joaquín González Álvarez. Cuerdas, Branas y Dimensiones. http://casanchi.com/ref/cuerdas01.pdf. 
muy difícil para la mente común (y aún para los expertos) imaginar o concebir lo que dicen los experimentos.

Pongamos por ejemplo la teoría del Big Bang, que asume que todo lo existente hoy en el universo, estaba contenido en un sólo punto muy caliente y muy denso. Primera cosa difícil de imaginar pues para nuestra limitada mente y la lógica a la que estamos acostumbrados, no nos permite fácilmente concebir que cuerpos tan grandes como el sol (que a su vez es una pequeña estrella entre todas las existentes), Júpiter o la Tierra, además de todos los cuerpos espaciales, estuvieran en un cuerpo tan chico como una naranja, digamos.

Luego, algo pasó que toda la presión y el calor existente ahí adentro, hicieron explotar esa naranja y salieron disparadas todas las galaxias y lo que existe en el universo. El sentido común me dice que debería preguntar en qué parte del espacio estaba esa naranja, pero los científicos nos dicen que antes del Big Bang no había tiempo ni espacio, estos dos elementos se crearon con la explosión.

La concepción del tiempo también es importante en la actual explicación científica. El tiempo que nosotros conocemos y usamos nos parece simple y posibilita el orden de las cosas en el medio en que diariamente nos desenvolvemos, pero cuando se empieza a tratar dentro de la ciencia, nos damos cuenta de que no tiene mucho 
qué ver con la ingenua definición que utilizamos en la vida cotidiana.

En cosmología, el tiempo se comporta de maneras muy extrañas: puede hacer que el pasado y el futuro se traslapen, que pierdan el sentido tradicional que de ellos tenemos. No tienen principio ni fin. Muestra características que van en contra de la lógica a la que estamos acostumbrados. Cuando uno, en su visión limitada, se imagina una explosión y por lo tanto una expansión, uno ubica el punto explosivo en algún lado, pero resulta que no existe un punto central de la expansión, que la explosión ocurre en todos lados y que el universo se expande de igual manera para todos lados pero sin tener ese centro. El universo es todo lo que existe, no tiene orillas pero tuvo un inicio difícil de ubicar.

Si no existía nada antes del Big Bang y fue a partir de ahí que todo se creó, entonces ¿cómo se puede decir que la materia, la energía y el espacio estaban concentrados en un punto? ¿Entonces sí existían esos elementos? Los neófitos batallamos para imaginar la explicación de la ciencia sobre estos temas pues están fuera del sentido común que manejamos.

Existen dos teorías sobre lo que pasará con nuestro universo: una afirma que el universo sigue en expansión y que llegará un punto en el que comenzará a contraerse y se llegará al Big Crunch para volver a empezar todo el 
ciclo de nuevo; la otra postura es que el universo seguirá expandiéndose para siempre y en un momento, todas las galaxias se enfriarán y se llegarán al Big Freeze o congelamiento de todo lo que existe.

El modelo aceptado en la física contemporánea nos habla de que hay materia y fuerzas que se interrelacionan y componen todo lo que existe. La materia tradicionalmente se pensaba compuesta por átomos, las partículas que durante mucho tiempo se pensó que eran las más pequeñas y básicas. Pero ahora se sabe que hay doce tipos de partículas que componen la materia: seis tipos de cuarks y seis tipos de leptones. $Y$ todas esas partículas en realidad son pequeñísimas cuerdas que vibran de manera distinta, como en los instrumentos musicales tendrían una caja de resonancia proporcionada por espacio-tiempo. A mayor frecuencia vibratoria, mayor energía. Las fuerzas que actúan sobre estas partículas son cuatro: la gravedad, el electromagnetismo y las fuerzas nucleares fuerte y débil cada una con sus partículas que actúan como transmisores de las fuerzas.

Se ha logrado describir cada una de esta partículas y fuerzas, con excepción de la gravedad, que aunque nos parezca la más familiar, da dolores de cabeza a los físicos cuando la tratan en el ámbito de lo muy pequeño; no se ha podido encontrar al portador de la fuerza gravitatoria, 
que sería el gravitón. ${ }^{121} Y$ se espera encontrarlo porque las demás fuerzas que rigen el universo tienen su propio portador y encajan bien con la estructura que se ha desarrollado gracias a las investigaciones. Es por esto que los teóricos se esfuerzan en lograr una teoría que explique su funcionamiento, y la teoría de las supercuerdas se ha mostrado como la opción más viable para construir un modelo que sirva para seguir los vaivenes de la gravedad a niveles cuánticos.

La teoría de las cuerdas manejaba en un principio la posibilidad de 26 dimensiones, y el concepto de una partícula que se consideraba presente pero inexistente, el taquión. Pero las investigaciones siguieron y se llegó a una teoría más completa que integraba la supersimetría (una teoría donde cada partícula tenía a su lado una superpartícula, lo que fue muy útil para avanzar en el conocimiento, aunque en la naturaleza no se presentan dichas partículas) y esto redujo las dimensiones para trabajar a solamente 10 , incluida la gravedad y no necesitaba la existencia de la partícula incómoda, la llamada partícula inexistente, el taquión.

Como podemos ver, la especulación ayuda a la concepción de nuevos mundos y de ahí surgió la llamada Teoría de las supercuerdas: afirma esta teoría que todo está formado por partículas que tienen la forma de

121 Joaquín González Álvarez. Cuerdas, Branas y Dimensiones, p. 3. 
pequeñas cuerdas, y que hay una sola especie de cuerda que vibra según la dimensión (de las diez aceptadas) donde se encuentre y esto determina el tipo de partícula que se identifique.

La cuerda vibra y depende de esa vibración la partícula que emite. El ejemplo típico para entender esto es la cuerda de un instrumento, según la vibración que le demos es la nota que emite. $Y$ como la cuerda no es un punto, sino que tiene extensión, tuvo éxito en fusionar la gravedad y la mecánica cuántica, que habían tenido cada una su explicación hasta antes de la elaboración de la teoría de las supercuerdas.

Esta teoría proporcionaba simetrías que no se encontraban en la física de partículas, lo que permitió soñar en que el conocimiento se podría acercar a una teoría que funcionara para lo pequeño y para lo grande, es decir, permitiría explicar la composición de la materia y la estructura del universo. La teoría de las supercuerdas relaciona armónicamente la gravedad y la mecánica cuántica y esto da pie a promesas de explicación de la materia y las fuerzas que la mueven.

Las vibraciones del mundo de lo más pequeño ahora podían coincidir y explicarse de la misma manera que las vibraciones del tejido espacial y sus grandes dimensiones. A pesar de que nadie ha visto nunca una cuerda, esta teoría promete y permite avances en la investigación y los 
científicos afirman que vale la pena seguir trabajando sobre ella pues si se logra que los mundos de lo infinitamente grande y lo infinitamente pequeño se puedan explicar desde una misma estructura teórica, entonces se habría dado con la teoría correcta y verdadera del funcionamiento del universo para que los datos teóricos encajen con los datos experimentales, sin inconsistencias matemáticas.

Pero no ha sido fácil el avance, pues los físicos simpatizantes de la teoría de las supercuerdas encontraban ciertos problemas, y esto animaba a los escépticos a afirmar que dicha teoría era sólo otro modelo matemático. Uno de los problemas tenía que ver con el número de dimensiones que eran aceptadas en el mundo de la física. Tradicionalmente se aceptaban tres dimensiones, pero un cálculo científico llevó a integrar hasta seis dimensiones espaciales más, además de la dimensión del tiempo, por lo que posteriormente se llegó a un mayor número que funcionaba para las ecuaciones.

Se agregaron nuevas dimensiones que iban dando congruencia a la teoría y se vio que sólo si se aceptaba un número mayor de dimensiones podía funcionar, hasta que se llegó a ver la necesidad de aceptar 26 dimensiones que daban resultados positivos para el avance. Y así avanzaba la que podía ser la teoría que permitiera la comprensión de las fuerzas y la materia. 
"Si estas ideas son correctas, el tejido ultramicroscópico del universo está bordado con la más rica de las texturas." ${ }^{122}$

Para explicarse, las ecuaciones de la teoría de cuerdas tuvieron que representar unas formas más complicadas que las esferas o círculos que usualmente se utilizaban para los cálculos: las nuevas formas hexadimensionales fueron descubiertas por los matemáticos Eugenio Calabi y Shing-Tung Yau mucho antes de que se supiera que tenían relevancia para la teoría de las cuerdas. Las formas de Calabi-Yau estarían rodeándonos por todas partes e incluso nosotros estaríamos llenos de ellas, pues esas serían las formas que tiene todo lo existente.
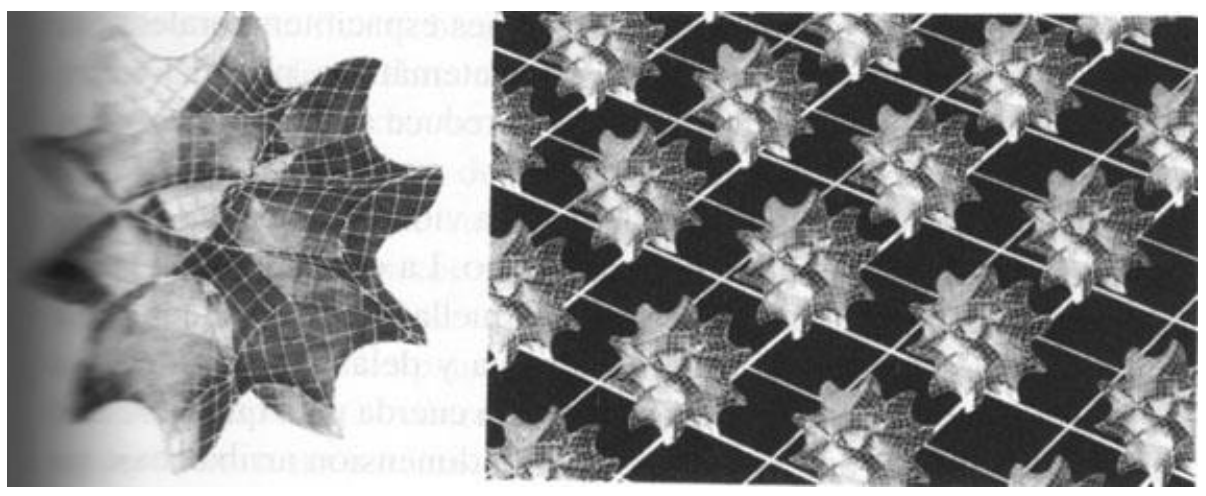

Formas de Calabi-Yau. Brian Greene. El tejido del Cosmos. ${ }^{123}$

122 Green, Brian. El tejido del cosmos, p. 469.

123 Idem. p. 469. 
Estas formas también estarían atadas a las tres dimensiones espaciotemporales tradicionales, por lo que todo se movería a través de las pautas vibracionales que definen dichas formas. Esto explica actualmente las propiedades de las partículas conocidas; y no queda ahí, siguen existiendo muchas formas más a las que la física se puede acercar por medio de los cálculos matemáticos. Esta nueva concepción del espacio y el tiempo proporciona una aproximación suficientemente satisfactoria para seguir en el camino de la comprensión del universo.

Existían varias versiones de la teoría de las cuerdas, por cuanto hay científicos que trabajaban con unas de las ecuaciones y científicos que trabajan con otras, pero todas compartían características esenciales como lo que se llama "hebras de energía vibrante".

Las diversas teorías se formulan según la concepción y actividad de la supercuerda: se encuentran las cuerdas concebidas como un hilo o abiertas y cuerdas como ese hilo pero con las puntas juntas, de ahí se deriva la opinión de que cuerdas abiertas pueden cerrarse o encontrarse con otra abierta y unirse a ella, o que dos cuerdas cerradas pueden también reunirse y formar una cerrada diferente y así hasta tener cinco variedades de la teoría. 
Esta variedad incomodaba mucho a los investigadores, pues aunque el marco general promete una explicación más clara de lo que nunca había sido, las diferencias sutiles rompían el sueño del marco teórico único que se buscaba. $Y$ de repente, a finales de la década de los ochenta, Edward Witten, basándose en el trabajo de muchos otros teóricos de las cuerdas, descubrió que las teorías existentes eran modos de acercarse a una única teoría, y así nació la teoría M. Esta teoría permitió integrar las cinco versiones separadas que existían y las cuales impedían una visión unificada al estar trabajando con resultados que habían surgido separadamente. 


\subsection{La teoría Mó de las membranas}

A lo largo de la historia, el ser humano ha intentado encontrar la explicación de lo existente y de su funcionamiento. Surge en nuestros días la teoría $M$, ¿por qué $M$ ?, hay varias propuestas, $M$ de madre, refiriéndose a la intención de los científicos por encontrar la fuente de todo lo que existe. $M$ de magia, misterio y milagro por lo que de oculto tienen que develar, y finalmente $M$ de membrana que es el nombre técnico de los modelos que intentan explicar la manera en que funcionan las fuerzas y partículas.

Por supuesto que es una cuestión complicada y terriblemente compleja en términos matemáticos y de física, pero afortunadamente hay estudiosos que intentan ponerla en términos entendibles para los neófitos así que en este trabajo se menciona de manera general y sólo para los fines del tema propuesto.

La teoría de las cuerdas no es infalible ni está completa, pero cada vez que se descubre algo, se ha podido avanzar congruentemente, lo que da muchas esperanzas a los físicos, aunque tiene sus detractores entre la comunidad de científicos quienes argumentan la falta de experimentación y de obviar algunos problemas, pero a mi 
ver, es necesario imaginarse senderos y poco a poco se sabrá si son los verdaderos o no.

Edward Witten, físico y matemático estadounidense, descubrió que la teoría $\mathrm{M}$ tiene no diez, sino once dimensiones espaciales y es justo esa nueva dimensión la que lograba conjuntar las distintas versiones de la teoría de las cuerdas.

Esa nueva dimensión especial construyó los senderos que se necesitaban para unificar las 5 distintas versiones que se estaban trabajando, pero también traspasaba los linderos de lo que se consideraban los límites de la ciencia, haciendo que el sentido común desapareciera tal y como lo conocemos. Esta dimensión era infinitamente larga, pero también muy, muy pequeña y en ese extraño espacio flota la membrana de nuestro universo.

Además se descubrió que no solamente las cuerdas unidimensionales serían los ingredientes que formaban la simetría necesaria para explicar la composición del universo, así que los análisis demostraron que hay objetos bidimensionales y se les llamó membranas. El universo entonces sería una membrana. A partir de ahí se avanzó y se encontraron membranas con hasta diez dimensiones espaciales, llamadas $p$-branas. $Y$ el número varía según las dimensiones que posean: 2-brana, 4brana, etc. 


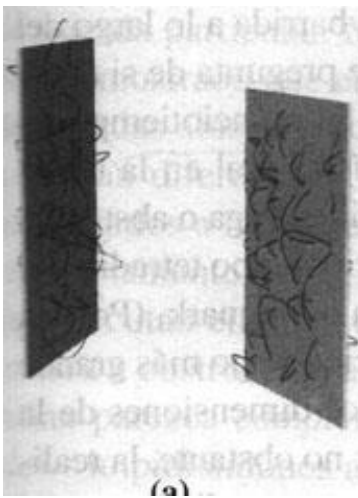

Distintos tipos de pbranas. ${ }^{124}$

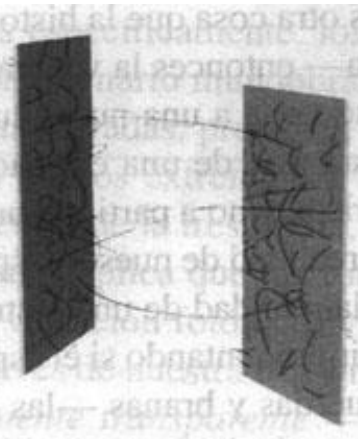

(h)

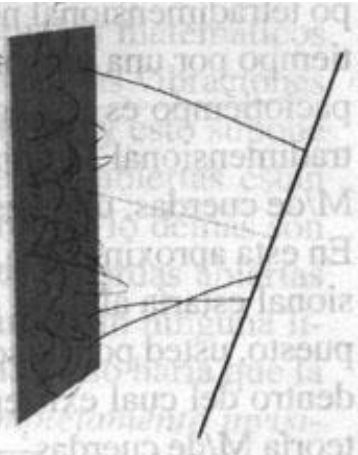

(c)

Distintos tipos de pbranas.

Las membranas se pueden enrollar y contraer. Esto no invalidó los trabajos anteriores con las cuerdas, más bien se descubrió que formaba parte de un mismo marco teórico, se logró una unificación. Las cuerdas serían las 1branas. Como las cuerdas son tan pequeñas, no hay aparatos en la actualidad que puedan hacer crecer una cuerda lo suficiente para poder observarla, así que por lo pronto son sólo los cálculos matemáticos los que nos permiten saber de su existencia y comportamiento, pero se cree que en la etapa que siguió al Big Bang, se crearon cuerdas largas que pueden haber sobrevivido y de las cuales podrían encontrarse huellas, por lo que esto

124 Brian Green El tejido del cosmos, p. 495. 
"quizá permita que la teoría de cuerdas sea confirmada algún día mediante observaciones astronómicas." 125

Estos descubrimientos y la existencia de muchas dimensiones en las branas, hace que pensemos en la posibilidad de que estemos viviendo en una brana, o lo que es más, que el universo entero sea una brana.

Anteriormente se sabía que había ciertas cuerdas que tenían varios cabos en los extremos y se llaman cuerdas abiertas. Se podía saber que estos cabos estaban sujetos a algo y ese algo resultó ser la brana, en la que se podían mover libremente, pero no abandonarla; por tanto esto haría que los fotones producidos viajaran libremente a través de nuestro mundo de tres dimensiones y serían invisibles para nuestros ojos que ven utilizando la fuerza electromagnética y esta fuerza es incapaz de acceder a cualquier dimensión distinta a las tres que nos son familiares.

Por su parte, las cuerdas cerradas pueden moverse entre las branas pudiendo dejarlas, meterse o abandonarlas así que esto podría significar que existen las otras dimensiones justo al lado nuestro y no nos damos cuenta. Los aceleradores de partículas están evolucionando y se espera que pronto alguno sea capaz de detectar alguna

${ }^{125}$ Brian Green El tejido del cosmos, p. 491. 
cuerda, y de conjuntar tal cantidad de energía que se podrían crear agujeros negros en miniatura que no serían dañinos, pero que nos permitirían entender más acerca de la creación y funcionamiento del universo. Los intentos de comprensión van hacia el estudio de la cosmología, e incorporando la teoría $M$ de cuerdas existiría una esperanza promisoria para explicar el origen y la evolución.

Por ahora, existen dos modelos que proponen la explicación del funcionamiento del universo: el modelo inflacionario, donde las membranas se expanden y se contraen en una especie de rebote, y el modelo cíclico donde existe una tres-brana que colisiona con otra tresbrana cercana y origina así otro ciclo cosmológico. Aunque ninguna de estas dos propuestas soluciona las cuestiones completamente, han servido para incorporar nuevas formas de pensar el espacio en el que nos movemos.

El avance en la integración de las diversas teorías existentes, ha llegado al punto de aceptar lo que algunos piensan imposible: los universos paralelos y la superposición de éstos, además de la explicación de la cuestión de la gravedad y su debilidad.

Una de las propuestas era que tal vez la gravedad se filtraba a esa onceava dimensión, hacia otro universo y por eso su debilidad ante las otras fuerzas que funcionan 
en el mundo, pero no cuadraban los cálculos. Luego se pensó que tal vez la gravedad se estaba filtrando, pero más bien de ese universo paralelo hacia el nuestro y eso acomodó lo que faltaba.

La explicación sería, entonces, que la gravedad se filtra hacia nuestro universo y por eso sólo vemos lo que queda, una fuerza débil. Las cuerdas abiertas están sujetas a la membrana y no pueden abandonarla, lo que significa que lo que existe en el universo no puede acceder a otra brana, y las fuerzas como el electro magnetismo o la fuerza débil o fuerte tampoco pueden ir a esa otra membrana existente. La única fuerza que puede hacerlo es la gravedad y es a través de ella que somos influidos por las otras membranas existentes.

Lo que se pensaba acerca de la onceava dimensión, era que era un sitio pacífico, pero después se pensó que tal vez las membranas se movían en ondas y podían colisionar unas con otras. La teoría de las membranas pudiera responder a la pregunta de qué hay antes del Big Bang, diciendo que hay un multiverso en el que los distintos universos existen como membranas que se mueven y colisionan creando Big Bangs frecuentemente. La existencia de las membranas explicaría el origen de la gran explosión y además permitiría la apertura al pensamiento de que en cada universo existen distintas leyes de las que no tenemos ni idea y que pueden 
contradecir la cuadratura de pensamiento a la que hemos estado acostumbrados desde la aparición de la ciencia como tal en la historia humana.

De esta manera, hay científicos que creen que se podría crear un universo en el laboratorio, sin ningún riesgo, porque dicho universo crearía su propio espacio, su propia materia y crecería en una dimensión que no afectaría en nada al mundo y en espacio en que vivimos. Cosa difícil de concebir en nuestro sencillo pensamiento influido muchos años por la supuesta solidez del comportamiento de la energía y la materia. Pero no para los físicos, quienes en los años venideros esperan que la teoría $M$ sea verificada experimentalmente, aunque las dimensiones que se manejan hacen difícil la construcción de aparatos que puedan detectar las cuerdas tan minúsculas y las membranas en las que todo existe.

El gran colisionador de hadrones es una esperanza para crear agujeros negros tan minúsculos que no nos causen daño y que puedan demostrar la existencia de las colisiones de las branas y la existencia de las partículas nunca antes vistas, es decir, las cuerdas en sus diversas manifestaciones vibratorias.

Varios modelos están siendo propuestos y trabajados por físicos entusiastas de todo el mundo. Las comprobaciones matemáticas están desarrollándose y se espera que sigan 
avanzando sin tropiezos, pues se está en las primeras etapas de la comprobación.

Las membranas y las cuerdas serían la esencia del tejido del universo y su entrelazamiento constituye el cosmos en que vivimos. $Y$ una multitud de nuevos conceptos ha hecho su aparición: cuerdas, membranas, lazos, ondas gravitatorias que son rizos en el tejido del espaciotiempo, materia oscura, etc. ${ }^{126}$ por lo que poco a poco los neófitos iremos familiarizándonos con ellos para, según se vayan comprobando, ser testigos de las implicaciones que tendrán en la vida cotidiana.

Llegados hasta este punto, podemos ver que la ciencia contemporánea también utiliza metáforas para explicar los hechos del universo. De alguna manera tiene que explicar a los legos en el asunto y entre ellos mismos, lo que los datos matemáticos producen. Pero incluso con las metáforas y las explicaciones que se tienen actualmente, si nos ponemos estrictos, se requiere una gran imaginación para poder concebir la explicación que nos muestra la ciencia.

Es difícil imaginar tanto un pequeño óvalo tan lleno de energía que al explotar diera origen a todo lo que conocemos como universo, con sus planetas, estrellas, hoyos negros, etc., como igual de difícil es aceptar que estamos formados y rodeados por diminutas cuerdas que

126 Uranga, Ángel M. Introducción a Física de Partículas..., p. 83. 
forman redes y membranas en las que existen universos paralelos y que todas las infinitas diferencias en las cuales se muestra la energía y la materia sean únicamente distinguibles por el tono o vibración que tiene cada minúscula partícula.

Pero la ciencia también tiene su lugar sagrado entre los humanos librepensadores y de mente inquisitiva y se prefiere esta interpretación que no forma un sistema cerrado sino que nos va conduciendo a nuevos descubrimientos y posibilidades de experimentación.

El tejido del universo no depende, desde la visión científica, de acciones de seres divinos, pero sí de la conformación de las fuerzas que se acomodan diariamente en el cosmos. $Y$ con las concepciones que han salido a la luz, muchos físicos (un ejemplo sería Fritjof Capra) están relacionando lo que se descubre en la ciencia con los antiguos planteamientos del misticismo entendido como la aproximación a la realidad última-, pues las implicaciones de las nuevas teorías los conducen a la reflexión sobre el libre albedrío, el azar, la conciencia, y otros muchos problemas a los que se ha acercado la sabiduría de todas la épocas, aunque ahora en un marco distinto, un poco más cerca de la ciencia y más lejos de dios.

Me gustaría poner aquí la clasificación que hace el Dr. Richard Novack del misticismo, sólo para aclarar un poco: 
Para intentar clasificar los varios tipos de místicos, puede ayudar la imagen de escaladores tratando se subir una montaña alta, en donde el tope de la montaña representa la más intensa y gratificante forma de existencia posible. (...) Todos los escaladores quieren llegar más cerca de la cima como sea posible para surgir o ser uno con lo que sea que ellos consideren ser lo último y lo más alto. Los cuatro o cinco senderos a la cima pueden ser caracterizados brevemente como sigue:

** Los místicos de la naturaleza parecer ser históricamente el más antiguo grupo, pero difíciles de diferenciar de los místicos religiosos porque las poderosas fuerzas de la naturaleza pronto fueron deificadas y adoradas como dioses, como se puede ver en los dioses griegos del Monte Olimpo. Probablemente cada ebrio se veía a sí mismo como adorador de Baco o Dionisio, y cada prostituta como una discípula de Afrodita.

** Los místicos religiosos son quizás el más numeroso y diseminado tipo de místicos. Ellos son lo que la mente popular reconoce más fácilmente como "místicos". Su más alta realidad es generalmente un dios personal con quien ellos quieren estar en los más íntimos términos posibles, ya sea como padre-hijo o como esposoesposa. San Francisco de Asís, Santa Teresa de Ávila, San Juan de la Cruz, (...) son buenos ejemplos. 
${ }^{* *}$ El misticismo intelectual cuenta con pocos adherentes pero incluye a algunos de los más ilustres nombres de la filosofía y la ciencia. La realidad es experimentada por estos místicos como una expresión de inteligencia creativa y pueden aproximarse más a través del conocimiento y el entendimiento: Platón, Aristóteles, Newton, etc.

**Los místicos sociales ven a sus congéneres humanos como la sacralidad última; la humanidad en sí misma es la cima de la montaña, y los místicos sociales quieren perderse y encontrarse ellos mismos en el servicio a sus semejantes: el Buhda y tal vez Gandhi y la madre Teresa son ejemplos.

**Los místicos de la vida, del arte, de la creación y quizás otras posibilidades esperan para ser exploradas y explicadas. ${ }^{127}$

El misticismo así entendido, comprende entonces a los físicos contemporáneos que buscan el entendimiento del universo. Y ahora con más razón, pues se han dado cuenta que se tienen que aproximar a la realidad última de las cosas de una manera muy diferente a la que el pensamiento científico nos tenía acostumbrados en el desarrollo de la ciencia.

El pensamiento científico se ha abierto en esa área del conocimiento y ha tenido que aceptar cosas que parecen

127 Novack, Richey. Me and the Big Bang, p. 195-96. 
de ciencia ficción o que inevitablemente caen fuera del sentido común, aunque me parece que se está construyendo una lógica distinta para poder seguir en la investigación.

Creo que el pensamiento científico ha dado un paso y al pisar ha logrado un avance que ha provocado que innumerables preguntas se presenten para darles respuesta. $Y$ las respuestas que se han encontrado dan pie a más preguntas, las preguntas más raras a las que ha tenido que enfrentarse la ciencia del último siglo. Tal vez las siguientes generaciones puedan ver satisfechas dichas cuestiones.

La metáfora del tejido y los elementos que la componen permiten que entendamos la conformación física del mundo, facilitan la comprensión de su estructura y cómo funciona para dar forma y concreción a todo lo que existe. Los hilos de los que estamos tejidos, son hilos de energía, hilos cuya diferencia no es el color o el grosor, sino la vibración.

Las membranas que construyen, son las telas que conducen las fuerzas energéticas para comportarse de determinada manera y dar sus propiedades a todos los elementos, visibles e invisibles que conforman el mundo conocido y por conocer. Sigue la metáfora del tejido en uso, sirviendo para explicarnos, como antaño, de dónde 
venimos y de qué estamos formados, así como determinar nuestro papel en el universo. 


\section{CAPITULO 4 Los mundos digitales}

Esta época contemporánea se mueve en mundos abstractos, la era multimedia se desenvuelve en canales de luz y ríos de datos energéticos; las imágenes electrónicas, las comunicaciones por satélite, la world wide web, etc., nos proporcionan un mundo virtual sobre el que descansa toda la sociedad contemporánea.

Aunque generalmente nos volcamos en la concreción que nos permite el acceso a dicho mundo, la verdad es que incluso algo tan corriente como el dinero, ahora tiene su significante abstracto en el mundo de lo digital. Ya no necesitamos ver siquiera un billete. Con una tarjeta plástica podemos acceder a cualquier tipo de compra, pagos, obtención de mercancías, etc., y todavía más allá, con sólo poner unos números en la computadora se mueven las finanzas individuales y mundiales.

-En este escenario, el arte también ha fincado sus dominios en los territorios de la electrónica y ha llevado la abstracción mucho más allá de lo que se había hecho anteriormente. Obras de arte difíciles de comprar, porque su ejecución depende de dispositivos que tal vez llegará 
un momento en que no funcionen por ser obsoletos y no se podrán reponer los accesorios o baterías, propuestas que no se pueden repetir de la misma manera, etc. Todo eso se mueve en un plano que hasta hace poco tiempo ni nos imaginábamos que podía existir.

Tanto el arte como la ciencia son procesos donde el individuo involucra una total dedicación, pues requiere de investigación, de experimentación y de mostrar sus resultados. El acto de crear está ahí puesto en su total expresión.

La ciencia y la tecnología permiten actualmente una nueva manera de expresar el arte y ambas, arte y ciencia, avanzan interrelacionándose, creando expresiones imposibles en cualquier otra época y haciendo ver el papel predominante de la interdisciplinariedad como un proceso rico y capaz de engendrar nuevos derroteros para completar nuestra visión del mundo, así como para que el individuo pueda desarrollar todo su ingenio.

El arte contemporáneo prosigue con la búsqueda y la exploración de estos dominios, y los artistas se apropian de las máquinas y los circuitos para poner su expresión a tono con la época. En este contexto pues, es notorio que algo tan primitivo y ancestral como las fibras y el textil tengan una fuerte presencia en el arte y sobre todo que se hayan acomodado tan bien en la expresión multimedia, digital y electrónica. 
La unión del textil y la tecnología ha dado sus frutos. Sus productos parecieran sacados de la ciencia ficción y aún hay muchos más que no han abandonado el campo imaginario, pero muchos textiles han sido desarrollados con distintas capacidades y ya se están produciendo para actividades especiales.

Tanto en la moda como en las actividades en que se necesitan propiedades distintas en las telas, los llamados textiles inteligentes están mostrando su maleabilidad y capacidad de aceptación para con las propiedades desarrolladas tecnológicamente. La física, la química, la ingeniería y la biología han interactuado con el ámbito textil para desarrollar prendas y utensilios que ayuden a los individuos en las actividades que realizan.

Se han desarrollado cosas como una tela que mantiene o produce calor para actividades tales como ejercitar 0 bucear en aguas heladas; o telas a las que se les puede dar propiedades luminiscentes, tal como una alfombra que brille en la oscuridad para ayudar a las personas a salir de un edificio en caso de alguna contingencia en la que se vaya la luz; o pantallas planas ligeras y flexibles con propiedades electroluminiscentes; o la aplicación de hilos metálicos para producir textiles conductores; textiles que repelen el agua o telas que repelen la mugre.

De igual manera cualquiera de las aplicaciones que se han desarrollado para prendas militares, tales como 
dispositivos electrónicos integrados a la tela que informan del lugar donde está la herida de bala; o de la frecuencia cardiaca y demás signos vitales, pero que también se pueden usar para protección civil, por ejemplo para detectar el nivel de oxígeno en un bombero o monitorear a un niño enfermo, etc.; hasta chalecos que se usen para recabar datos vitales de personas expuestas en el día a diferentes situaciones, o prevenir la muerte súbita en los bebés; sostenes inteligentes para las mujeres, la integración de los dispositivos móviles en la ropa, o detectores antisecuestro. Los textiles están respondiendo a necesidades de la sociedad actual al conjuntarse con los descubrimientos de la ciencia.

Y por supuesto que la expresión artística también ha encontrado la forma de unir los diferentes dispositivos digitales con el textil para dar forma a expresiones estéticas contemporáneas. Debido a los altos costos de los dispositivos, esto no está disponible aún para la mayoría, pero hay artistas que enfocan sus esfuerzos a esta área de la creación.

El área textil tiene un interés especial por la carga de género que tiene, y es curioso que, aunque existen artistas textiles varones, la inmensa mayoría de la expresión en este género pertenece a las mujeres. Y aunque esta condición ha ido cambiando y más hombres se suman a la experimentación con los materiales de esta 
disciplina, históricamente existe un predominio femenino en el que las mujeres han luchado por hacer a un lado, o modificar, la carga de inferioridad que todavía algunos piensan que tiene el hacer textil. $Y$ precisamente por esa carga creo que es un área en la que se puede mostrar específica y claramente la superación de dichos dogmas discriminatorios.

Las mujeres artistas han venido trabajando con materiales que se suponen destinados a funciones cotidianas y de pertenencia al hogar como estructura enclaustrante $y$ delimitante, y a mi ver, se ha llegado a una altura de expresión estética que logra salir de esas paredes para mostrar con toda su fuerza lo que las mujeres tienen qué decir. La cercanía con los materiales que conforman el arte de la fibra contemporánea, permite una familiaridad y un excelente desenvolvimiento para sacar de ellos nuevas estructuras artísticas.

Por eso la expresión textil y su desarrollo teórico me ha proporcionado tanta satisfacción, pues es el perfecto ejemplo del trabajo con algo que significaba discriminación y ahora se muestra como una plena expansión de la inteligencia y creatividad femenina entrando a los dominios que durante siglos fueron coto exclusivo de lo masculino.

Toda esa creatividad desde la mujer para todo el mundo y en plena demostración de nuestras capacidades en un 
emparejamiento que va más allá de la idea de géneros contrapuestos. Gracias a la constante lucha de las mujeres a través de la historia — donde siempre ha habido mujeres artistas, pero ocultas o subordinadas a una figura masculina-, es que ahora podemos construir sólidamente la visión femenina del mundo.

Creo posible recuperar, a modo de las sociedades prehispánicas, el elevado nivel de lo femenino con toda su riqueza como sujetos creadores de algo superior y gracias a las predecesoras, lograr saltar los cánones sociales preestablecidos por la sociedad mediática en la que vivimos y forjar lo esencial femenino sin acentuar ni la igualdad ni la diferencia, sino existiendo como seres humanos en todas sus posibles manifestaciones.

A pesar de que la construcción y programación de las computadoras se instala socialmente en el estereotipo del ámbito masculino, el surgimiento de los dispositivos digitales y sus aplicaciones han dado una entrada más para la expresión femenina, aunque a lo largo de la historia también hay mujeres destacadas en la ciencia. Sólo por poner a un ejemplo podemos traer a la memoria a Ada Lovelace y sus contribuciones matemáticas y de programación.

Por estos tiempos, han surgido nuevos conceptos que intentan analizar la relación de lo femenino con las 
máquinas. $^{128} \mathrm{El}$ ciberfeminismo ha comenzado a posibilitar la acción femenina en un campo donde puede dialogar con la computadora y se plantea la necesidad de participar creativamente en la cultura técnica, para hacer desaparecer el esquema que separa a la mujer de la tecnología. ${ }^{129}$

En el nivel más básico de la programación de computadoras, hay una analogía con el procedimiento del telar, ya que la secuencia de ceros y unos en el lenguaje digital equivale a si el hilo de la urdimbre cruza o no los lisos para lograr la puntada. $Y$ aunque hay cierta consideración tradicional y prejuiciosa acerca de que las mujeres no manejan bien las máquinas, en este caso las computadoras han facilitado la construcción de los medios para la expresión artística.

Los mundos digitales han creado una realidad alterna en la que se pueden aprovechar las leyes de la física, y por medio de los cálculos matemáticos, reproducir o aplicar los fenómenos que ocurren en el mundo real para construir una expresión distinta a todo lo que se había visto en épocas anteriores. $Y$ se enlaza con la realidad de tal forma, que se puede dar origen a algo totalmente

\footnotetext{
128 Véanse los artículos relacionados en: http://emujeres.net/sites/default/files/Ciberfeminismo_Creatividad\%20y\%20c omunicacion.pdf 129 Para ahondar en el tema véase el libro de Sadie Plant Ceros +Unos. (Destino, 1998)
} 
concreto 0 , si se quiere, a algo maravillosamente intangible. 


\subsection{Hacia una creación textil en la era multimedia}

Textiles inteligentes.

Los textiles han llegado a establecer relación, en cuanto a su recorrido a través del arte, con varios ámbitos de la tecnología y la ciencia. Desde los años sesenta, cuando los pioneros de la fusión de la tecnología con el textil dieron a conocer sus primeras propuestas, que eran prendas de vestir con los dispositivos electrónicos añadidos, se intentaba mostrar que la computadora no era un aparato rígido, sino que podía transportarse y llevarlo consigo para interactuar con él.

"El diseño de prendas computacionales se asume a sí mismo con la estética de las prendas de vestir mejoradas por la tecnología o por materiales innovadores con propiedades reactivas. La tecnología no es el punto focal de las prendas, sino la belleza estética, las interacciones únicas y los comportamientos interesantes que surgen como resultado de conjuntar la tecnología con la ropa. La tecnología en las prendas computacionales debe ser tan invisible como el hilo que mantiene juntos los pedazos de tela en la prenda."

"La computación que se puede poner, por otro lado, se refiere a la funcionalidad, fortaleza y 
utilización de la tecnología cuando ocupa espacios en el cuerpo." 130

La electrónica ha incursionado en las prendas de vestir cambiando las propiedades de la ropa, que ya no es sólo para cubrirse o para mostrar los significados de pertenencia, sino que se pretende que dé acceso a otros campos de la comunicación y dé apertura a nuevos significados personalizados y a nuevas reacciones en lo que llevamos puesto. Es actualmente uno de los campos muy estudiados para descubrir aplicaciones nuevas que permitan esta conjunción de la ropa y la computación.

La computación suave es descrita por Joanna Berzowska como el

..."diseño de la tecnología electrónica y digital que está compuesta de materiales suaves tales como textiles e hilos, así como también la que predica los métodos de construcción tradicional para crear diseños físicos interactivos." "La computación suave abarca el uso de hilos y telas conductivas, materiales "reactivos" (básicamente, cualquier material que pueda alterar de alguna manera:

\footnotetext{
130 Wearable computing, on the other hand, is concerned with the functionality, robustness, and usability of the technology as it inhabits spaces on the body. http://acg.media.mit.edu/people/megan/thesis lo res.pdf, consultado el 6 de enero de 2012. P. 21.
} 
cambio de color o forma, brillantez, etc.), sensores flexibles, y pequeños microcontroladores y componentes electrónicos que permitan la construcción de circuitos en sustratos suaves. Eso implica retirarse de la electrónica tradicional y una exploración de materiales emergente que puedan permitir la computación física. La meta es alcanzar una integración natural de la tecnología dentro de la tradición textil y el diseño de moda."131

Un ejemplo de los experimentos que se han hecho, es la llamada mascota artificial, que se realizó en el laboratorio canadiense donde Joanna Berzoeska dirige la investigación en los textiles digitales. Es una pieza hecha de hilos que cuelga de la pared y que tiene sensores que permiten la emisión de sonidos y la percepción de cercanía del usuario. ${ }^{132}$

$131 \mathrm{http}: / /$ www.horizonzero.ca/textsite/wear.php?is=16\&file $=4 \&$ tlang $=0$ Berzoeska $(2005,69)$

132 http://www.horizonzero.ca/textsite/wear.php?is $=16 \&$ file $=4 \&$ tlang $=0$ 

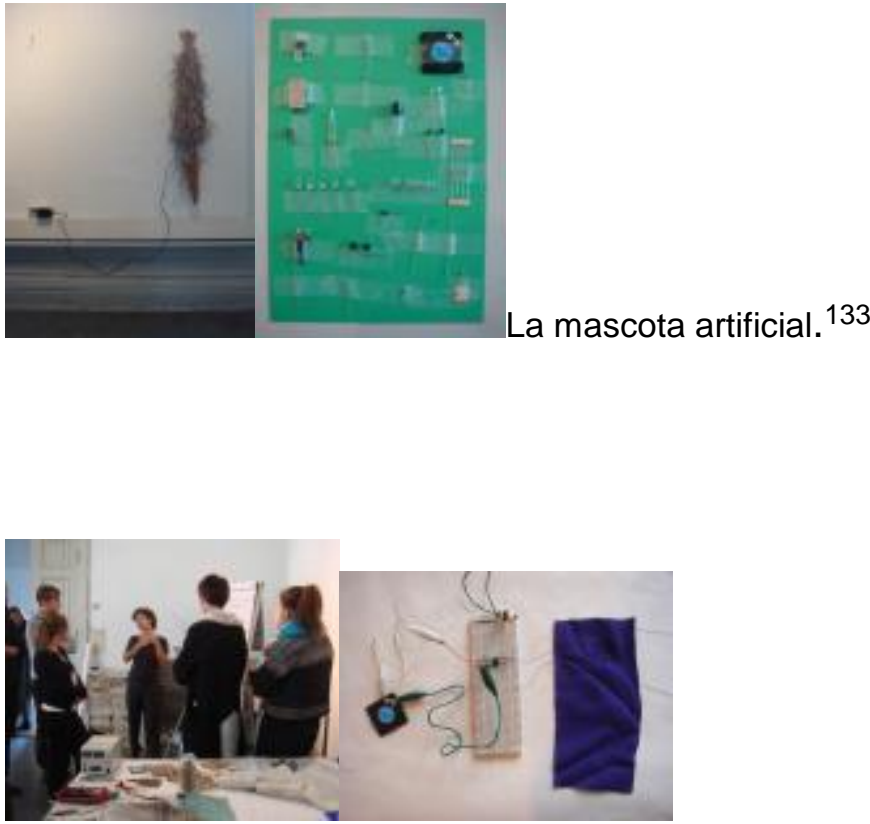

Cuando el dueño de la mascota llegara a casa, los sensores percibirían su entrada y movimientos, por lo que la mascota emitiría sonidos que permitan tener una sensación de compañía en la casa y de respuesta ante la actividad del usuario.

Por su conductividad y flexibilidad, los textiles han sido objeto en las últimas décadas de aplicaciones tecnológicas y científicas de punta y existen varios intentos de integrarlas a la moda.

"El 2010 proclama el comienzo de una nueva década en tecnología aplicada a la moda con el

${ }^{133}$ http://www2.khib.no/futuretextile/archives/tag/joanna-berzowska 
lanzamiento de numerosos productos comerciales exitosos, comisiones altamente visibles para proyectos $\mathrm{e}$ instalaciones $\mathrm{y}$ avances en tecnologías y materiales."134

Los textiles han cobrado importancia también como materia para desarrollar nuevas tecnologías. Los nuevos materiales han posibilitado que se produzcan telas que superan las cualidades de cubrir el cuerpo humano solamente por protección contra el clima o como representación de la moda en curso. Las posibilidades que se están encontrando van desde una tela que regule la temperatura corporal, hasta la posibilidad de leer a distancia los signos vitales de quien la viste.

Los llamados textiles inteligentes, abarcan una amplia gama de combinaciones entre los hilos, y cuestiones tales como la electrónica, la cromática, las nanopartículas trabajando en los materiales, ya se han aplicado a cuestiones de trabajos específicos o el ámbito médico, así como también a la moda. Como siempre sucede, las distintas aplicaciones de los nuevos materiales comienzan con usos militares, que es donde se invierte más en experimentar y lograr nuevos avances; además, la

${ }^{134}$ Seumour, Sabine. Functional Aesthetics. Visions in fashionable technology, p. 16. 
cercana relación que establecen con la ciencia, permite el uso de los nuevos descubrimientos en cosas prácticas.

Se ha hecho una clasificación de los textiles inteligentes y sería como sigue:

"Definición y clasificación de los textiles inteligentes.

Los textiles inteligentes han sido definidos como textiles que pueden sentir y reaccionar a las condiciones ambientales o estímulos de fuentes mecánicas, térmicas, químicas, eléctricas o magnéticas. De acuerdo a su actividad funcional los textiles inteligentes pueden ser clasificados en tres categorías:

Textiles inteligentes pasivos: La primera generación de textiles inteligentes que sólo pueden registrar las condiciones o estímulos ambientales, son llamados pasivos.

Textiles inteligentes Activos: La segunda generación posee sensores y actores. Los actores detectan la señal directamente o también desde una unidad central de control. Los textiles inteligentes activos poseen memoria exacta, son camaleónicos, resistentes al agua y al vapor, permeables (hidrofílicos/no porosos), mantienen el calor, son termoregulables, absorben el vapor e incluyen telas que emiten calor y trajes que se calientan con electricidad.

Textiles ultra inteligentes: la tercera generación de textiles inteligentes son los textiles muy 
inteligentes, que pueden sentir, reaccionar y adaptarse a las condiciones 0 estímulos ambientales por sí mismos. Un textil muy inteligente consiste esencialmente en una unidad que trabaja como el cerebro, con cognición, razonamiento y capacidades activantes. La producción de textiles muy inteligentes es ahora una realidad después de una exitosa alianza de los textiles tradicionales y la tecnología de telas con otras ramas de la ciencia tales como la ciencia de los materiales, la mecánica estructural, la tecnología de sensores y actuantes, la tecnología de procesos avanzados, la comunicación, la inteligencia artificial, la biología, etc.

Las nuevas fibras y materiales textiles, así como los componentes electrónicos miniaturizados, hacen que sea posible la fabricación de textiles inteligentes, con el fin de crear ropa inteligente que realmente se pueda usar. Esas ropas inteligentes son usadas como ropas ordinarias, dando ayuda en varias situaciones de acuerdo a las aplicaciones para las que se diseñaron."135

El uso de polímeros y distintas aleaciones en las telas, hacen que sea posible obtener este tipo de textiles y estas aleaciones pueden diseñarse para que tengan memoria y

135 (sacado de

http://www.indiantextilejournal.com/articles/FAdetails.asp?id=852)

Consultado el 2 de enero de 2013. 
así poder reconocer cuándo es necesaria la protección contra el frío o el calor. Otros materiales que cambian de color se han utilizado también añadiéndolos a las telas y diversos estímulos provocan ese cambio de color, tales como la luz, el calor, la presión, etc. Los materiales se manipulan a nivel molecular y se programan para reaccionar de determinada manera. ${ }^{136}$

La utilización de membranas en las telas deportivas, les confiere un mejor intercambio de aire y humedad. Dichas membranas de polímeros se insertan en las telas y dan como resultado una prenda más apropiada para hacer ejercicio. También sirven como protección para tener unos muebles o ropa más limpia. En cuanto a la moda las fibras fotoluminiscentes están resultando muy atractivas al igual que en ropa diseñada para protección. La electrónica también se está usando para, por medio de hilos delgadísimos, pasar corriente por el pecho con el objetivo de distinguir la diferencia en la corriente entre células sanas y las que se han desarrollado por un tumor. También se ha diseñado un teclado de computadora bordado en tela con tramas conductoras.

Otra prenda en la que se está trabajando es un traje para bebé que permite monitorear los signos vitales y la actividad del bebé, buscando evitar la muerte de cuna $o$

\footnotetext{
136 http://www.ptj.com.pk/Web\%202004/08-

2004/Smart\%20Textiles.html.
} 
alguna complicación si el bebé padece alguna enfermedad.

Muchos materiales tienen el protagonismo en esta búsqueda de nuevos materiales que puedan servir para mejorar las condiciones de vida y ayudar en las actividades humanas. La cerámica en fluido, las resinas de polímeros, la fibra óptica, telas como la organza metálica de seda, los filamentos de acero inoxidable, partículas de grafito, capas de cobre, cristales, microcápsulas, etc., son algunos de los muchos materiales con los que se está experimentando para fusionarlos a las prendas de vestir con innumerables aplicaciones, en donde sólo la imaginación marcará los límites.

Aún falta mucho camino por recorrer, pero la aplicación de los nuevos materiales y la tecnología de punta están contribuyendo para que en un futuro no muy lejano, dichas propiedades se puedan utilizar a nivel comercial y cotidiano. ${ }^{137}$

El arte textil está tomando ventaja de esta evolución de los hilos y las telas combinadas con la tecnología. Varios artistas alrededor del mundo están trabajando con sensores, hilos con luz, fibras que permiten una utilización

${ }^{137}$ http://www.ptj.com.pk/Web\%202004/08-

2004/Smart\%20Textiles.html. 
de la electricidad, el sonido o el video para dar efectos en sus obras.

La mencionada artista canadiense Joanna Berzowska, que dirige un laboratorio donde se investiga y se diseñan prototipos de textiles inteligentes, nos habla acerca de la computadora "vestible" que a mediados del siglo pasado diseñó Steve Mann, y que era solamente una computadora añadida o guardada en los bolsillos de una prenda de vestir y por tanto pesaba y los cables estorbaban, por lo que Berzowska menciona la necesidad de utilizar hilos conductores integrados a la esencia misma de la prenda que se viste, una tela que sea capaz de recibir, emitir y otras funciones, además de ser realmente parte de la segunda piel que es para nosotros el vestido. ${ }^{138}$

Los mundos digitales han expandido su influencia sobre todas las áreas de la vida. El arte está también instalada en la expresión a través de dichos medios y varias disciplinas se encuentran desarrollando formas, combinando sus particularidades con las de dichos mundos conocidos ahora por todos. Los procesos multimedia han dado cabida a distintos modos de hacer el nuevo arte.

${ }^{138} \mathrm{http}: / /$ www.horizonzero.ca/textsite/wear.php?is=16\&file $=4 \&$ tlang $=0$ 
El trabajo de la fibra se encuentra cómodo con la tecnología. $Y$ esto no es algo que nos asombre, pues desde que se inventó la máquina de vapor, la industria que más se modificó fue la textil, así que no es de extrañar que el telar pudiera fácilmente adaptarse a los últimos avances de la tecnología hechos en ese tiempo. Ahora el trabajo de los telares con la computadora es cosa normal, pero su utilización para producir arte va a hacia otra dirección, muy distinta a la que sigue la producción industrial.

\begin{abstract}
"En un tiempo que está más y más dominado por la imagen visual y el culto a la comunicación, los textiles también tienen la habilidad de mostrar nuestras necesidades y deseos, como también nuestras obras de arte"139
\end{abstract}

La relación de los hilos y telas con lo digital y lo electrónico apenas está empezando a explorar nuevas posibilidades y maneras en que lo textil se adapte a las nuevas formas computacionales.

La tela ya no es solamente la metáfora de la segunda piel, está construyendo otra imagen en la que las reacciones de lo que vestimos toman personalidad propia, no son ya objetos inanimados, están adquiriendo presencia por su

139 http://www.xslabs.net/papers/texile05-berzowska.pdf 
capacidad de reacción y eso nos lleva a relacionarnos con ellos de otra manera. Se obtiene una nueva forma de expresión personal, ya que se proyecta que en un futuro la ropa pueda expresar al individuo que la usa, no solamente como distintivo, sino como un dejar ver algo de la interioridad por medio de los efectos que los demás podrán percibir por medio de las prendas.

Si a lo largo de la historia el textil ha acompañado al humano y reflejado su propio ser en el mundo en el que vivía, ahora el tiempo en el que vivimos también motiva a la investigación de manera que se integre toda la comunicación lograda con la cobertura textil que forma parte de nuestro vivir en el mundo. Pero se busca que esté integrada de una manera natural y no solamente añadida.

Una de las preguntas que los investigadores se hacen es acerca del por qué queremos que nuestras ropas tengan funciones electrónicas y de comunicación, para qué nos van a servir. También se debate acerca de la privacidad, en el caso de los textiles que pueden enviar datos de la persona que lo está usando a algún receptor en segundas manos. Y están las cuestiones prácticas que hay todavía que resolver como la fuente de energía de esos dispositivos electrónicos que se busca sean parte de nuestro modo de mostrarnos al mundo. 
La relación con el textil ha sido siempre cercana a través del tiempo y ha sufrido muchos cambios en cuanto a estilos y materiales se refiere y actualmente se está investigando para poder integrar al textil y a la electrónica. Viene otro cambio en la manera con la que nos relacionamos con el textil.

"Los elementos computacionales pueden inspirar un sentido de vida en los objetos que antes eran inanimados, redefiniendo cómo nos relacionamos, usamos y pensamos acerca de nuestra ropa." 140

Ya no se trata sólo de cómo hacer portátiles las computadoras o aditamentos electrónicos, sino que las investigaciones van dirigidas a lograr una tela que sea capaz de percibir y transmitir datos variados que nos permitan estar integrados al mundo digital en el que se mueve la sociedad.

\begin{abstract}
"La tradición de la manufactura y diseño electrónico es producir componentes duros encapsulados en cajas cuadradas. La tradición de los textiles es producir estructuras suaves que cubren el cuerpo humano. Fusionando las dos, nosotros podemos crear circuitos suaves y
\end{abstract}

\footnotetext{
140 http://acg.media.mit.edu/people/megan/thesis lo res.pdf consultado el 6 de enero 2012, p. 10.
} 
desarrollar nuevos métodos para el diseño electrónico, con sensores que perciban el cuerpo y transmitan energía y datos. ${ }^{141}$

Como ejemplo podemos mencionar a Alyce Santoro, una artista digital que teje prendas con cintas de casetes y sobre las cuales se pasa una cabeza magnética y emiten sonido, pues la cinta conserva sus propiedades magnéticas. Otra artista que relaciona la tecnología con el tejido es Rachel Beth quien trabaja con el tejido de materiales distintos siempre en conexión con las computadoras.

La manera de existir en el mundo de hoy, da una importancia suprema a la comunicación y al manejo de las computadoras con todas sus posibilidades, y las partes que forman el mundo digital, la parte física y la parte abstracta, nos sumergen en un ámbito desconocido hasta hace algunas pocas décadas.

Y no sólo la ciencia depende ahora de lo digital, sino que se ha extendido a la vida cotidiana y a las relaciones personales. En muchos niveles, la vida no se entiende ya sin los aparatos; las generaciones jóvenes no comprenden cómo podíamos vivir sin computadoras, sin teléfonos celulares, sin televisión.

\footnotetext{
141 http://www.xslabs.net/papers/texile05-berzowska.pdf consultado el 6 de enero 2012.
} 
Mihaly Csikzentmihalyi un reconocido psicólogo húngaro que trabaja en Estados Unidos y que ha desarrollado el término de flujo dentro de sus estudios sobre la creatividad y la felicidad, escribe que los artefactos físicos nos ayudan a objetivar el ser de tres maneras: pueden ser vistos como símbolos de poder personal, símbolos de la continuidad del ser a través del tiempo y símbolos de la permanencia de las relaciones que definen lo individual en un marco social.

En base a esto, el tener un aparato electrónico, tal como un celular superpoderoso que tiene funciones que a veces ni el mismo usuario comprende o utiliza totalmente, dota de un sentido de poder a quien lo porta. La reducción en el tamaño de dichos aparatos ha permitido que se transporten fácilmente y se saque provecho de sus múltiples funciones.

Poseer un aparato nos da un sentido de ubicuidad, puesto que si estamos conectados a la red, no importa dónde estemos, formamos parte de una comunidad que está en constante comunicación y por lo tanto sentimos que podemos estar en muchos lados, con varias personas al mismo tiempo. Las relaciones a través de los aparatos se han vuelto más importantes que las relaciones directas; cosas que no se pueden decir de frente, se dicen teniendo a un aparato como intermediario y da una sensación de seguridad. 
Las relaciones con gente que no conocemos o que conocimos pero no hemos visto en mucho tiempo, se dan a través de la comunicación electrónica que facilita el contacto y nos da la sensación de la perduración de dichas relaciones a través del tiempo.

Las redes de comunicación se forman con nuestras acciones a través de los dispositivos. La red digital es tanto, o para algunos mucho más importante $y$ satisfactoria que la red social o familiar. Los hilos que tendemos para tejer nuestra vida con los otros, se extienden mucho más fácil en el abstracto mundo a que nos da acceso la electrónica.

Los textiles están entrando en ese mundo, las telas que nos cubren nos permitirán el acceso al mundo digital de una manera tal que nuestra "segunda piel" hará maravillas que ahora sólo imaginamos. 


\subsection{Una metáfora actual: tramas de hilos, luz y sonidos en el arte.}

La expresión contemporánea en el arte, recorre caminos antes insospechados. La integración de las distintas disciplinas, el trabajo comunitario de los artistas, la búsqueda de unión entre elementos disímbolos, la incorporación del mundo digital y el desbordar los límites antes trazados, son cualidades que encontramos en el arte actual.

El uso del textil ha sido adoptado por muchos artistas que comprenden las cualidades y el potencial de las fibras como conductoras de sensibilidad. Pondré aquí algunos ejemplos de los artistas que han encontrado distintas, peculiares pero bellas expresiones con los materiales que nos ocupan, para ir conduciendo la metáfora de tejercrear el mundo. 


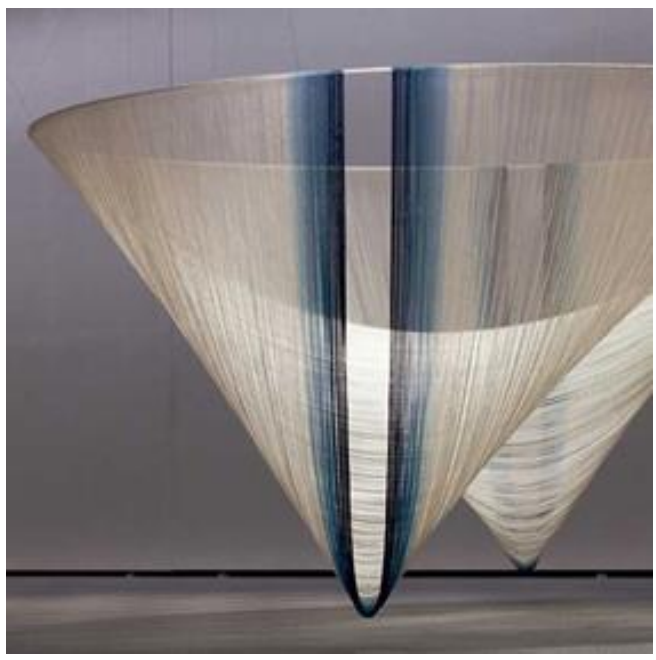

Akio Hamatani's W-Orbit, 2010

El trabajo de Akio Hamatani muestra la bondad del hilo formando por sí mismo telas, volúmenes multiformes, con el orden de la secuencia lograda por las telas. La ocupación del espacio se muestra como una contención del aire, una delimitación apenas dibujada por la naturaleza delicada de los hilos. Formas que nos enseñan nuevos modos de habitar ese aire. Su trabajo nos permite ver hilo a hilo el acomodo de figuras que parecieran imposibles con esos materiales. Cuerdas suspendidas formando mundos nuevos. El arte oriental se muestra con gran finura y expresión en el trabajo de este artista, uno de los principales representantes del fiber art japonés.

Con la expresividad que se ha encontrado en las fibras, los mundos etéreos pueden ser habitados. 


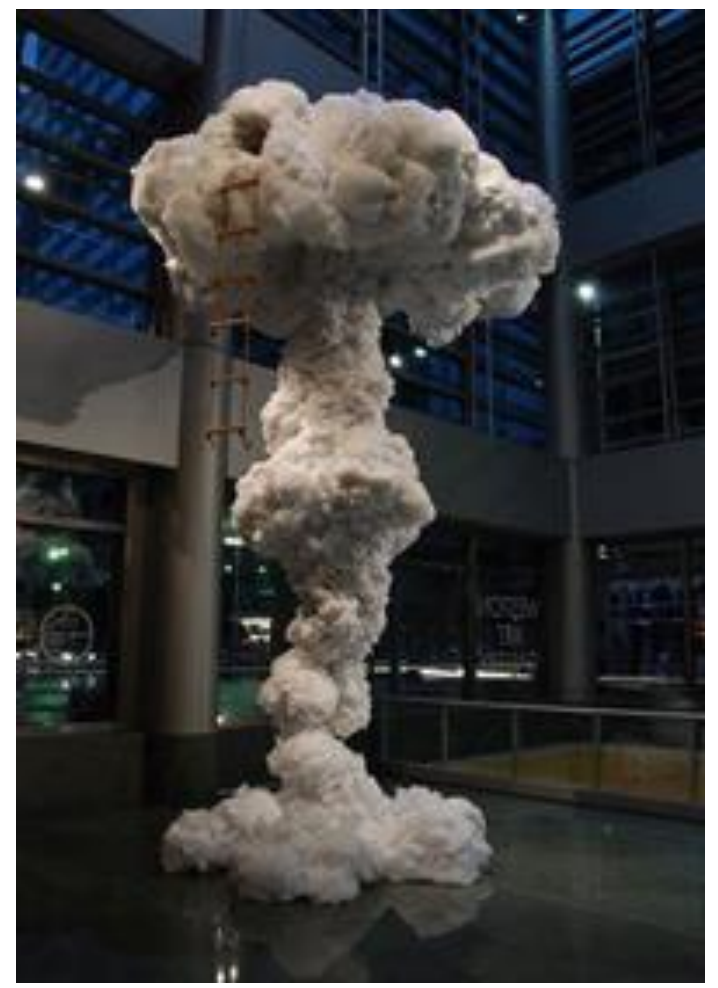

Dietrich Wegner. Playhouse 2012

Esta obra de Wegner, la fibra asciende por la sala para crear una nube habitable. La escalera de soga, demasiado corta para tomarla desde la tierra, puede interpretarse como un lazo tendido para el ascenso, pero implica un esfuerzo para quien, abajo, intente de alguna manera alcanzarla. Me recuerda los mundos prehispánicos donde el árbol del centro del mundo conectaba los niveles del cosmos y las tradiciones árabes 
donde por una cuerda encantada se podía tener acceso al plano divino.

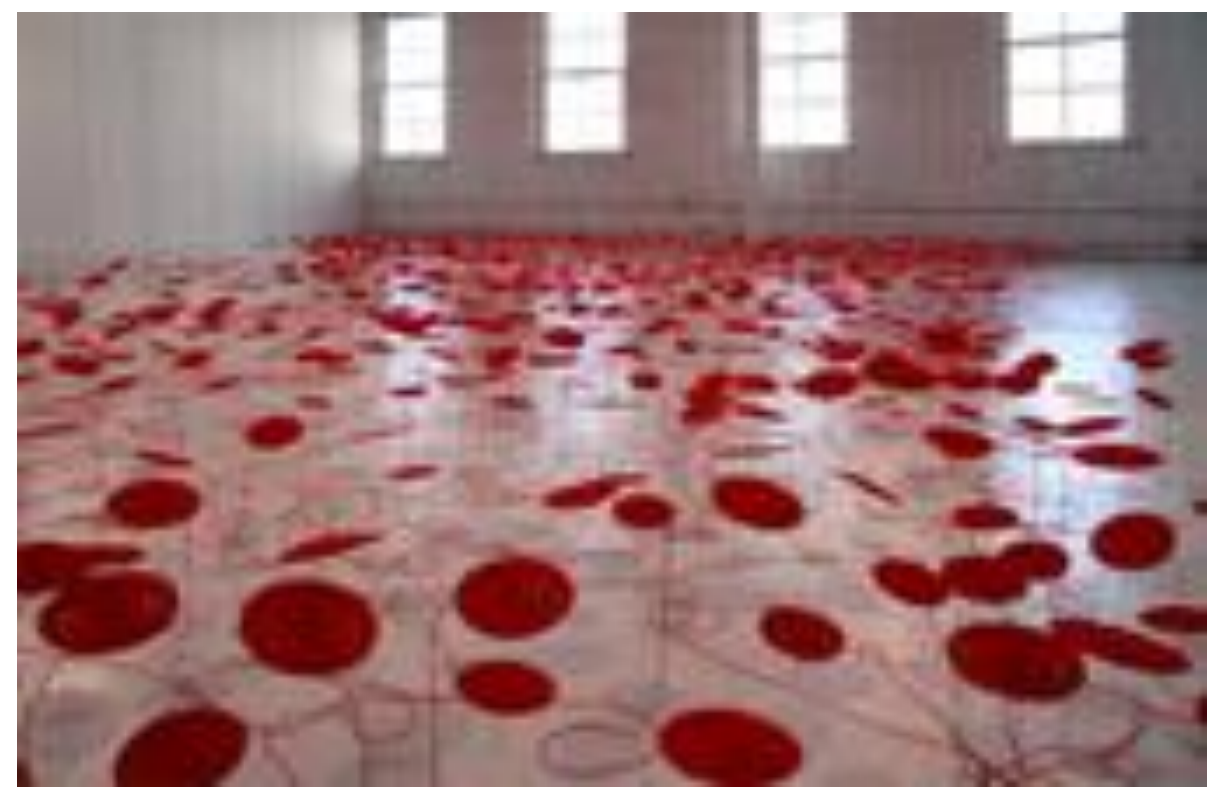

Beili Liu. The red thread 2008

En esta instalación de Beili Liu, el hilo ocupa diferentes alturas. El color rojo se esparce en las hebras que se distribuyen por el suelo. El hilo rojo ya no sólo es un hilo, son platillos flotantes que dan la idea de un campo de flores. Flores planas, rojas, creciendo en el estéril piso de una galería.

Los sentidos se estimulan y perciben de manera determinada por nuestro ambiente, por las cosas que nos 
son familiares o que nos gustaría que existieran. La imaginación en la vigilia y los sueños que recordamos, nos llevan a lugares que sabemos casi imposibles, pero, ¿no son posibles en el momento en que son pensados?

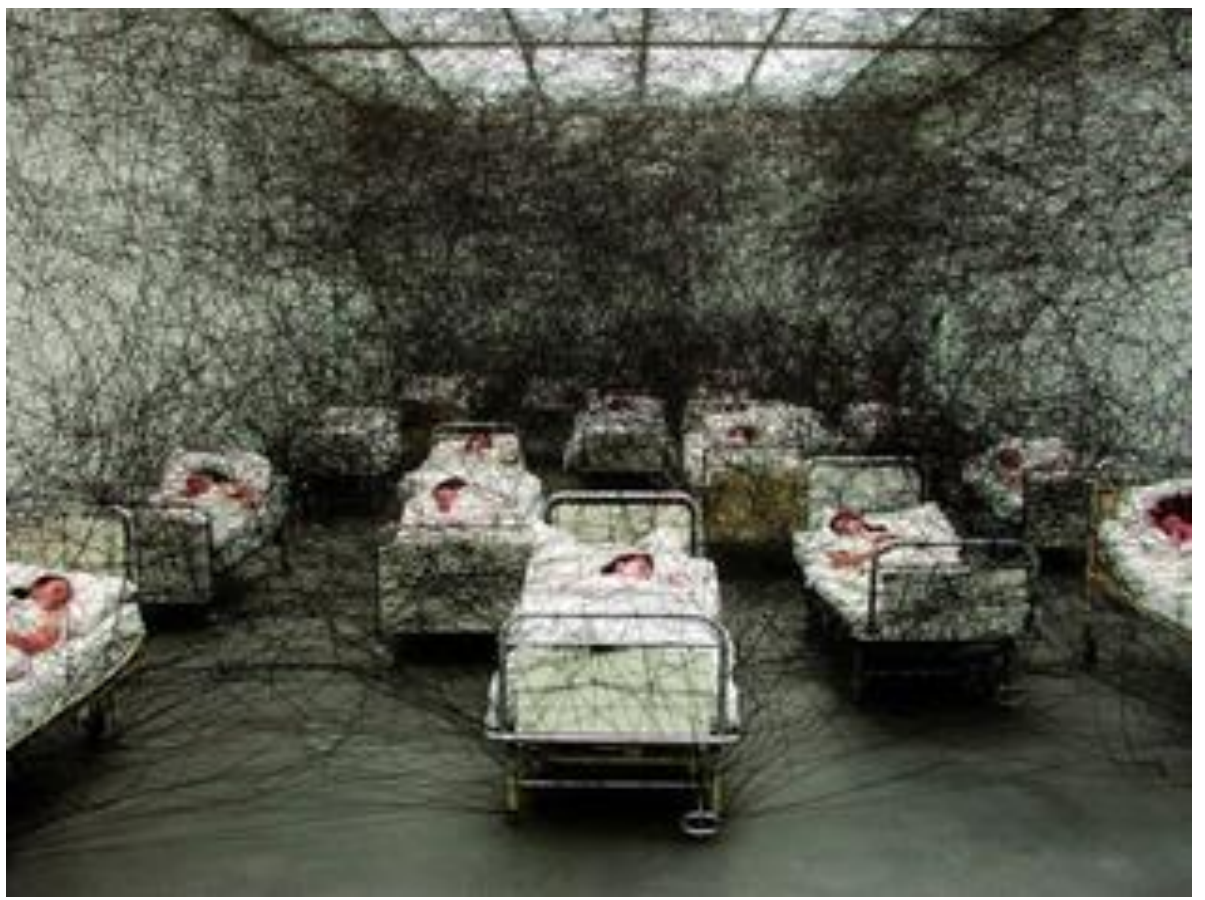

Chiharu Shiota. During sleep 2005

Cuando soñamos, tal vez nos conectamos de maneras misteriosas. Y en esta obra de Shiota, se representan las conexiones, las marañas que forman nuestros sueños. Nuestra existencia en un mundo que nos parece irreal cuando despertamos, pero que es totalmente convincente cuando nos encontramos dormidos. 


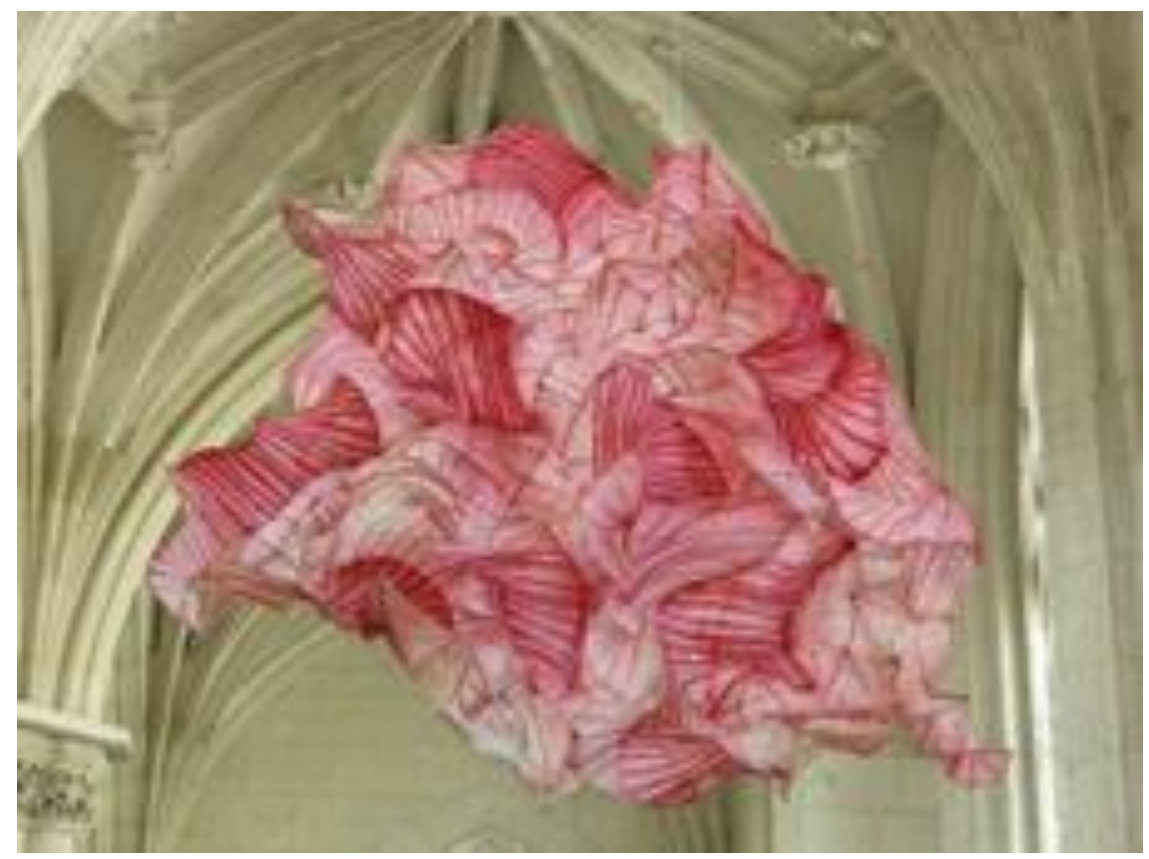

Peter Gentenaar. Eternal flame

Una flama hecha de tela, suspendida entre columnas clásicas nos hace detenernos ante la complicación de sus formas.

Formas que flotan como en los sueños, que extienden su existencia mostrándonos posibilidades. Del sueño a la realidad, las obras contemporáneas nos muestran los temas y símbolos que en nuestra época predominan. 


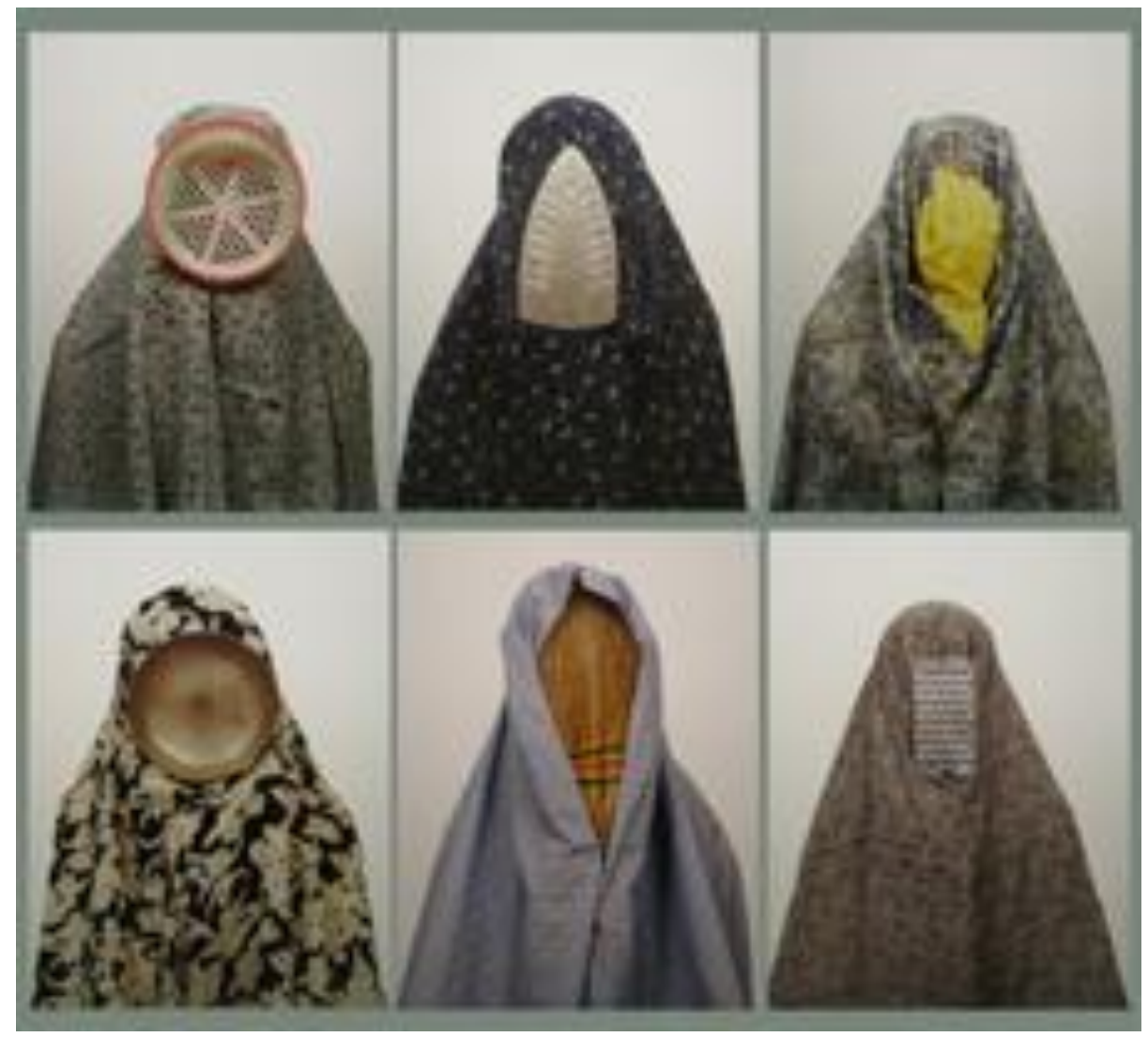

Shadi Ghardirian. Domestic life 2002

El abordaje de la situación femenina, por ejemplo, donde hay temas con múltiples connotaciones, se ve reforzada por el uso de telas, vestidos, hilos, fibras, que simbolizan muchas de las actividades que han sido yugo de la mujer. La obra anterior nos muestra precisamente la pertenencia de las telas que cubren a lo femenino y las constriñe a un ámbito al que se las relegó durante siglos. 


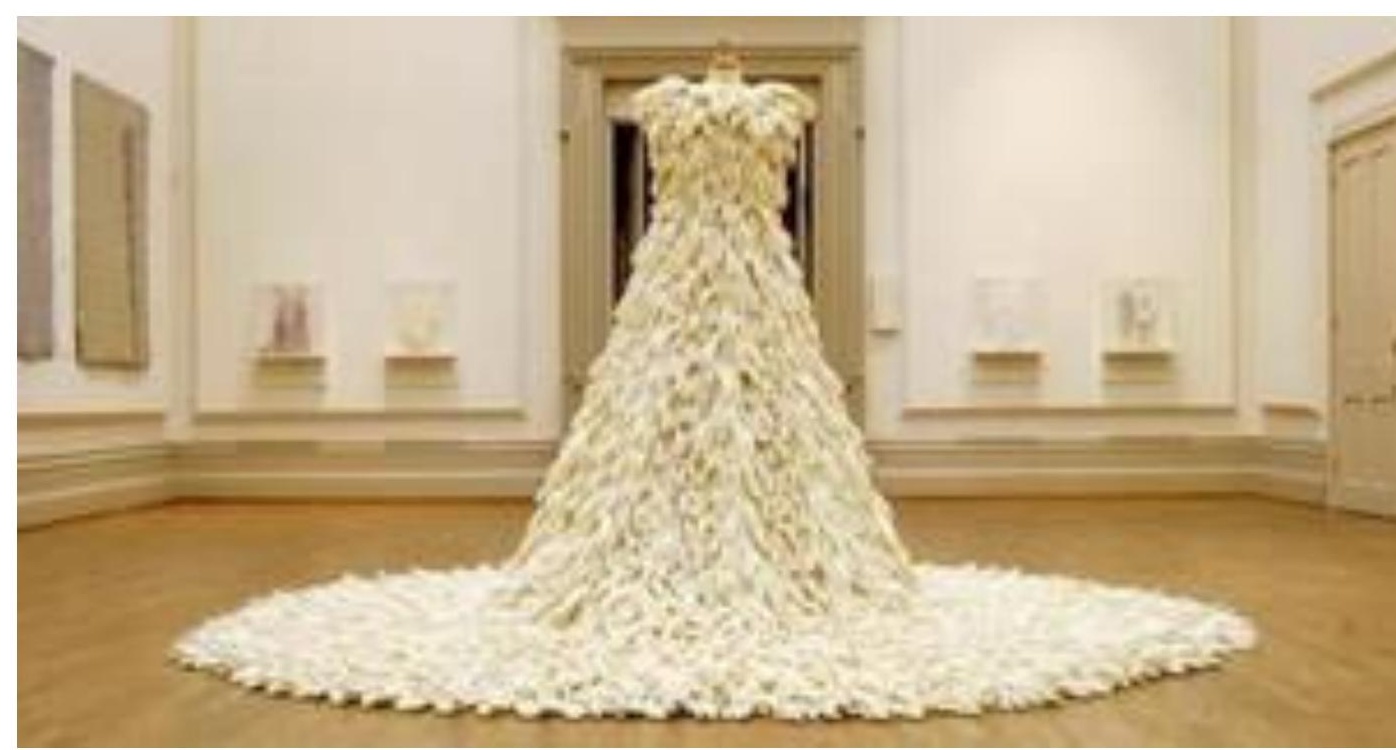

Susie MacMurray. The eyes of the skin.

Susie MacMurray representa la relación obvia que se hacía ( $y$ en muchos lugares todavía se hace) entre el matrimonio y el quehacer doméstico como obligación femenina, El vestido de novia está formado de guantes que se usan para realizar las tareas domésticas.

La vida cotidiana alterada por el arte nos parece que tiene una impresión más fuerte cuando se trabaja con fibras, hilos o telas. Son materiales que nos rodean, que son parte tanto de la naturaleza como de la cercanía con nuestra piel. 
El vestido de las mujeres tiene múltiples connotaciones en la siguiente obra

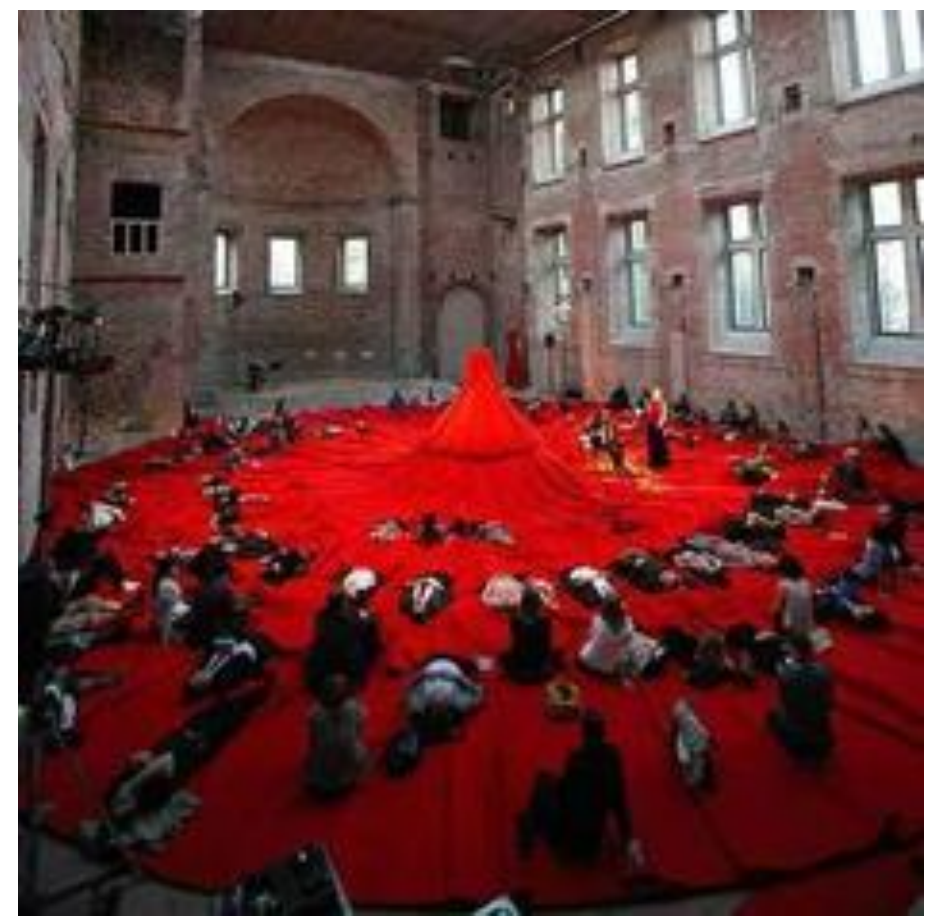

Aamu Song. The Red Dress. 2011

En él te puedes recostar, cobijarte con él, sentarte sobre él y abarca a muchas personas. En la obra de Song, se daba un pequeño concierto para los "habitantes" del vestido. El disfrute estético a través de la música también era parte de todas sus funciones. 
La tela envuelve: envuelve cosas, pieles, sensaciones, emociones; envuelve muertos, vivos, todo lo queremos envuelto con la calidez de la tela.

Regina Frank es otra artista que trabaja con la metáfora del vestido, de la tela y los hilos. Construye la unidad de lo humano con lo que nos cubre. En su trabajo analiza la vida interior y la exterior y la fragilidad de las dos partes de nuestro ser.

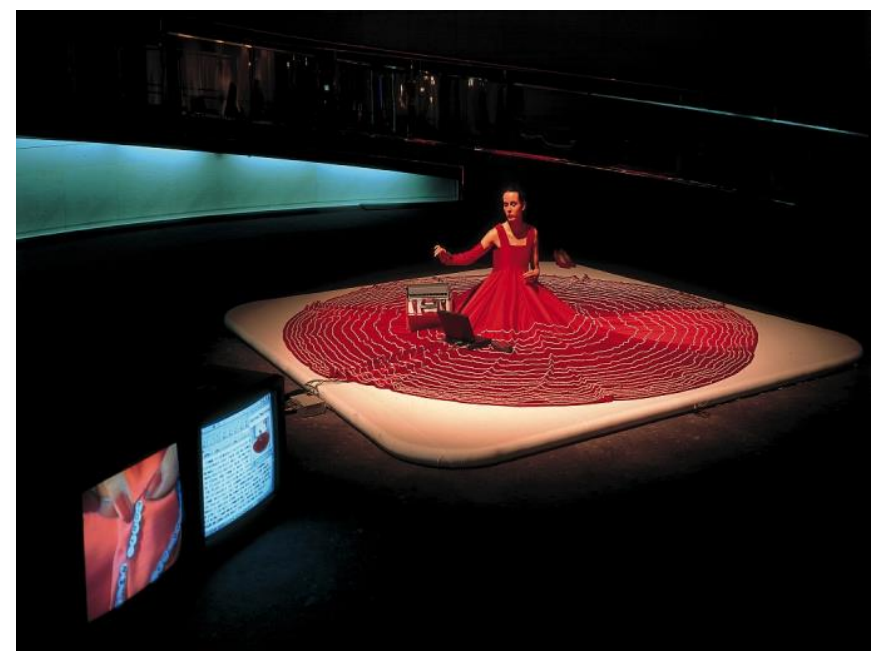

blogs.angolinfo.com

Su trabajo además incluye las computadoras para presentar realidades simultáneas en una obra que no se agota con el objeto, sino que se enriquece y continúa con el suceso. Su trabajo busca integrar varios aspectos dentro de los que se mueve: la espiritualidad, las matemáticas, la música. $Y$ quiere descubrir dónde queda el ser humano ante los elementos narrativos. 
El traje que portamos nos distingue, al mismo tiempo que nos iguala, dependiendo de los cánones que seguimos en la sociedad en que vivimos. Un tendedero de sacos ejecutivos colgando entre edificios públicos hace pensar que también ésos se lavan, se sacuden, se tienden al sol. La presencia de alguien enfundado en un saco nos hace pensar en la carga que conlleva usar esas prendas: alguien que quiere ser 0 es exitoso en el sentido financiero del término, que es lo más ansiado por una gran parte de la población en nuestra cultura actual.

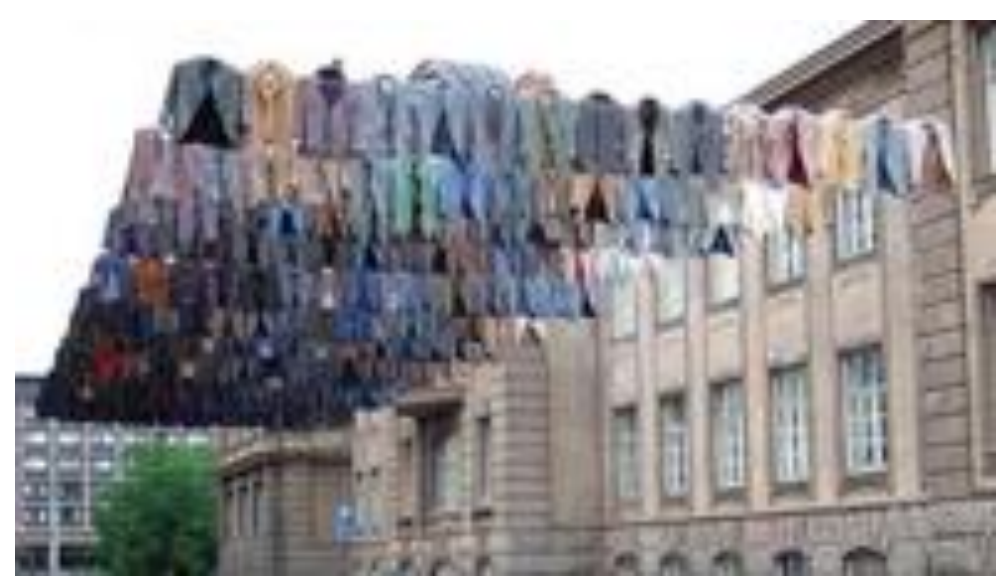

Kaarina Kaikkonen

También nos remite a la ausencia, a que están sujetos a la inclemencia del tiempo, a ser tocados por el sol, el 
viento, la lluvia. Inalcanzables pero igual de indefensos ante la naturaleza que el resto de los mortales enfundados en otro tipo de ropa.

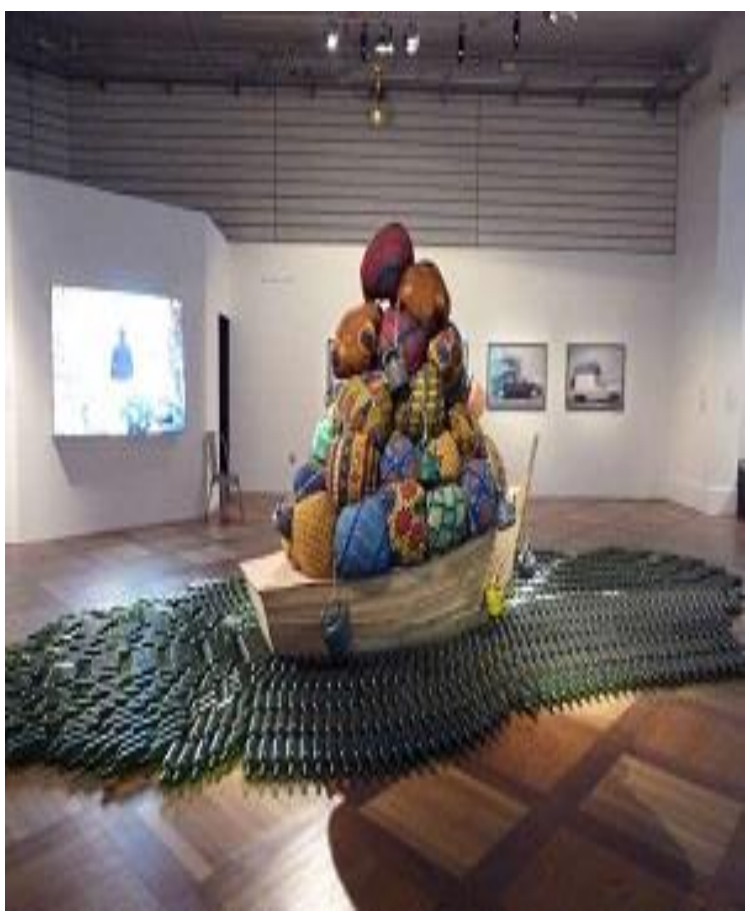

Barthélémy Toguo. Road to exile. 2010

En esta obra de Toguo se envuelve todo lo que queda de una vida cuando ésta se dirige al exilio. En esas maletas de telas multicolores está todo lo que vivió, todo lo que le pertenece, todo lo que llevará consigo, no importa a dónde vaya, no importa dónde atraque su barca. $Y$ todo ese bagaje nos pesa, pero no tenemos forma de deshacernos completamente de él. El universo es una tela 
que nos envuelve a todos y a todo lo que existe. $Y$ seguimos creando universos dentro de universos.

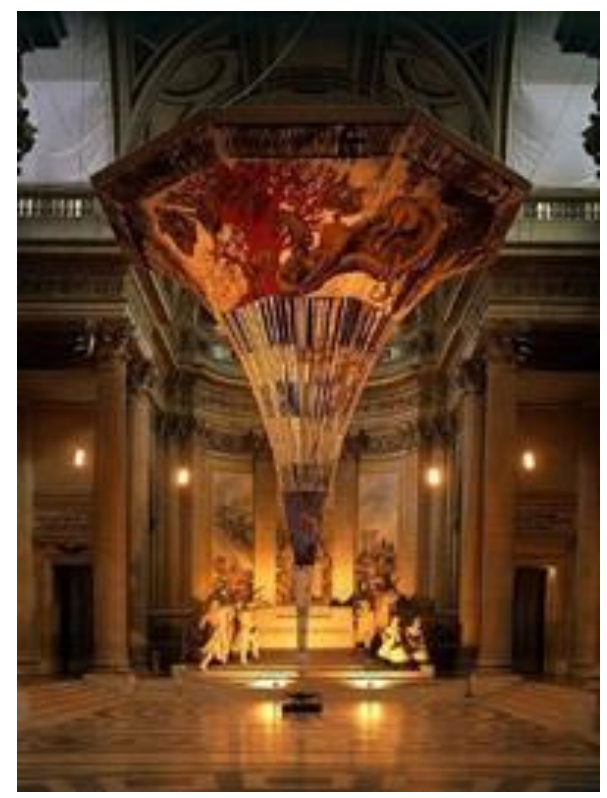

Gérard Garouste. Sacred Ellipses 2006

Las salas y los espacios interiores se llenan de una manera distinta que con la pintura o la escultura, esa organicidad de las piezas permite encontrarles una pertenencia con los espacios, no importa qué tan disímiles sean, puesto que tendemos a considerar más nuestras las fibras y las telas. El espacio es ocupado de una manera que sólo puede lograrse con las fibras. 


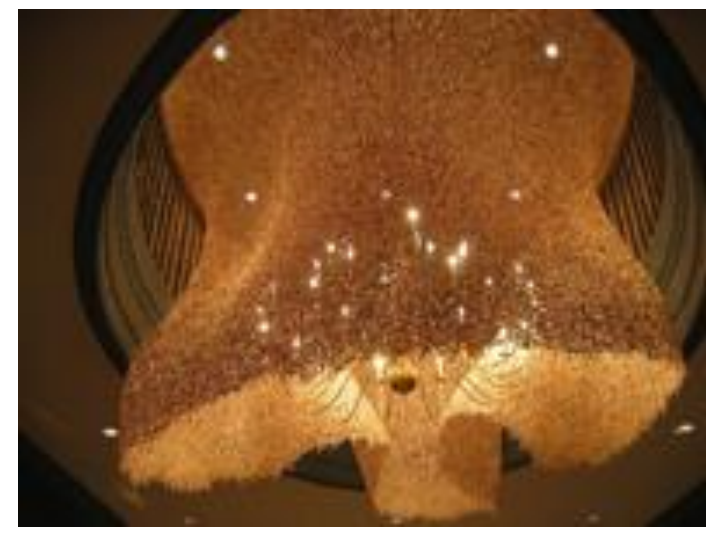

Jonathan Brilliant. Have sticks will travel world tour. 2009

Los sentidos pueden verse desafiados, encontrar sensaciones que no deberían estar ahí y los artistas han encontrado cómo conducirnos a esas latitudes inesperadas, pero a la vez tan conocidas.

Ernesto Neto desafía a los interactuantes de la obra que podemos ver abajo, con aromas de especias que se desprenden cuando se camina por entre las redes puestas en la galería. Aquí la percepción visual se ve alterada por el efecto de transparencia de las redes y el olfato se estimula trayendo recuerdos que cada visitante evoca en cada paso. 


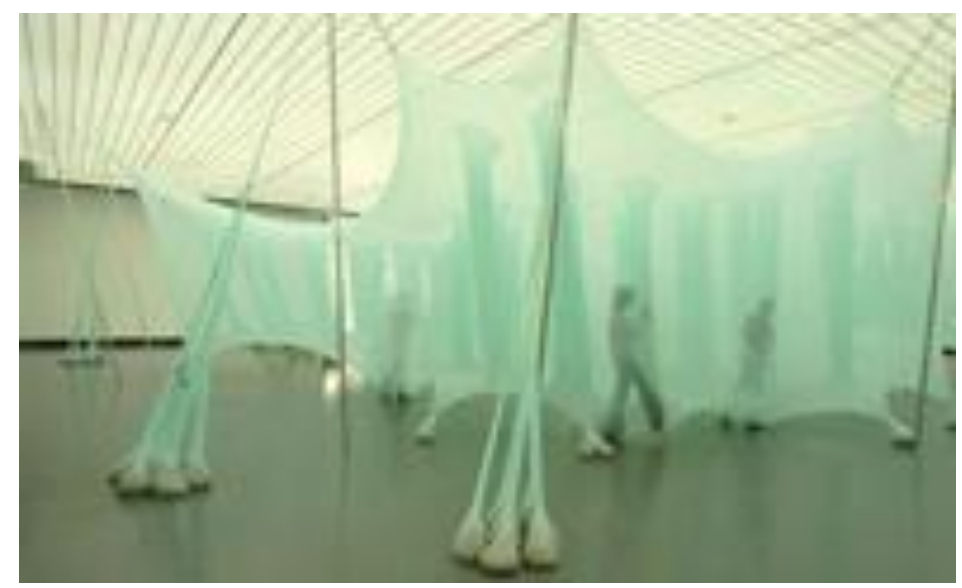

Ernesto Neto Célula nave especias laberinto

La recreación de mundos a través de distintos materiales también está presente en el trabajo con fibras. Un león de crochet, por ejemplo, pierde su fiereza, se convierte en un violento choque entre lo que representa la figura y el concepto que culturalmente tenemos del material. Pero a su vez dialoga con el entorno versallesco en donde se presentaron.

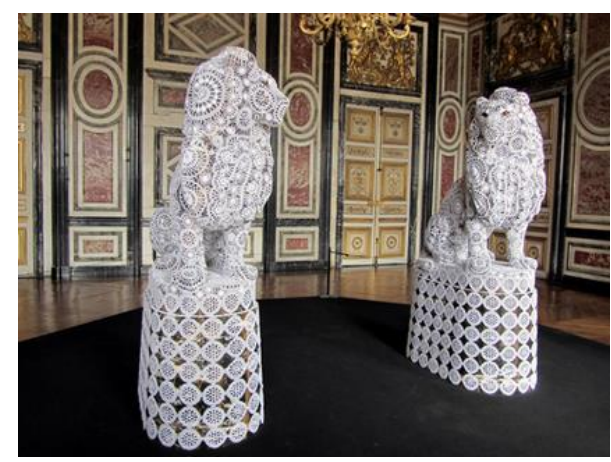

Joanna Vasconcelos. Gardes 2012 
$Y$ mundos en miniatura, perfección que nos sorprende y que se acentúa cuando sabemos que Mayet trabaja con cables, tela, papel y acrílico para lograr la bella manufactura de árboles desgajados, con resabios de la tierra a la que algún día estuvieron anclados y que cuelga de sus raíces.

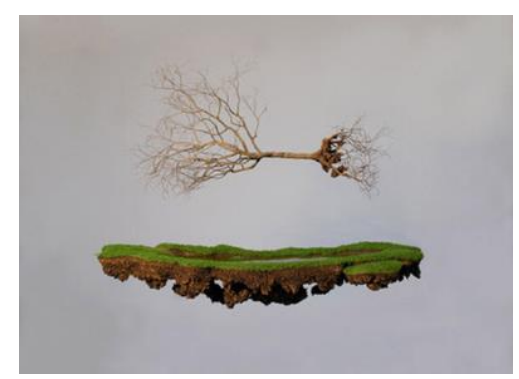

Jorge Mayet.

El ámbito terrestre apenas se detiene entre las delgadas líneas que añoran la tierra en que nacieron. Y ahí está la tierra, presente, inalcanzable, sintiendo la carencia de esos troncos.

Otras obras pueden recrear un espacio delimitado por la transparencia. El manejo de las formas en la siguiente obra de Jaume Plensa permite ver las sólidas cabezas que imponen por su expresión, pero al mismo tiempo nos permiten ver más allá, como si pudiéramos atravesar lo físico e ir a un mundo que puede estar formado en la mente de las esculturas. 


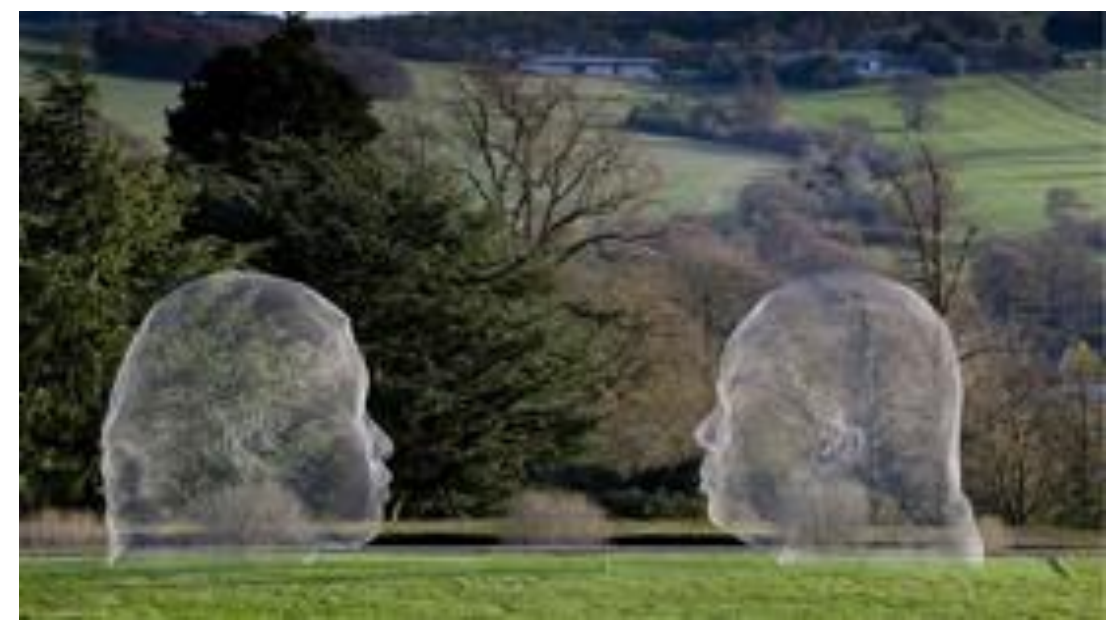

Jaume Plensa. S culpture. 2011

Los hilos y las fibras se han desplazado hacia la invasión del espacio, jugando con el desplazamiento que pueden alcanzar dichos materiales. El desdén hacia ellos ha quedado solamente en sectores que no conocen las manifestaciones contemporáneas a las que dan lugar. Las combinaciones a las que puede someterse a los hilos, telas, membranas y cuerdas, han llevado a experimentar con hilos eléctricos que forman redes luminosas significantes. 


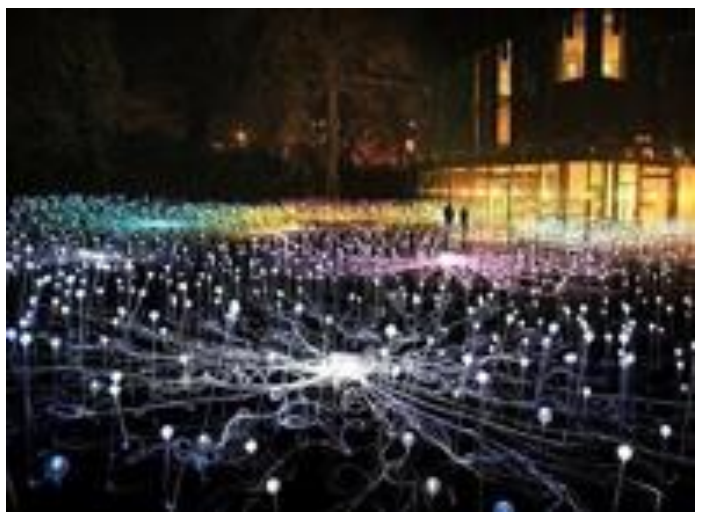

Bruce Munro. Field of ligth 2012

Munro instaló un campo de hilos luminosos que transitan por el acceso al edificio. Los hilos surgen de centros que conducen enredos lumínicos por todo el terreno y cada uno termina con un bombillo como concentrando toda la energía que fluye por cada conducto.

De la sociedad actual enmarañada por los hilos de la comunicación, en los paisajes cruzados por los hilos que transportan electricidad, en las señales eléctricas que cruzan el espacio que no vemos pero que nos permiten comunicarnos a través de sonidos, imágenes y palabras escritas en las pantallas, es donde se teje la red electrónica que mantiene a la sociedad tal y como la conocemos.

El arte se muestra actualmente más permeable a las distintas disciplinas de las que puede tomar elementos que sirvan para su expresión, y se presenta también un 
modo de trabajo colaborativo que permite la comunicación y la extensión de las ideas artísticas.

Los artistas jóvenes establecen redes de cooperación no solamente por internet, sino construyendo relaciones en su ámbito local. Las nuevas generaciones tienen que construir su estructura profesional aprovechando todo lo que tienen a su alcance, pues la cantidad de competencia puede hacer que sea muy difícil obtener los recursos para sostener su profesión.

$$
\begin{aligned}
& \text { "Las artes visuales conforman hoy en día un } \\
& \text { campo cultural en transformación, en el que } \\
& \text { confluyen estructuras tradicionales y nuevos } \\
& \text { procesos de creación, distribución y consumo } \\
& \text { artístico, exigiendo herramientas conceptuales } \\
& \text { flexibles y comprensivas." } 142
\end{aligned}
$$

Nuestro mundo es complejo y la complejidad es un tejido que junta muchas relaciones y fuerzas. Tal como se da en el mundo de la energía que estudia la física cuántica, se da en las relaciones humanas y en la práctica artística

$$
\begin{aligned}
& \text { "La esencia de la práctica artística radicaría } \\
& \text { entonces en la invención de relaciones entre }
\end{aligned}
$$

\footnotetext{
142 http://www.articaonline.com/wp-

content/uploads/2011/07/jovenes_culturas_urbanas_completo.pdf.

Consultado el 12 de enero de 2013.
} 
sujetos; cada obra de arte encarnaría la proposición de habitar un mundo en común, y el trabajo de cada artista, un haz de relaciones con el mundo que a su vez generaría otras relaciones, y así hasta el infinito." (Bourriaud, 2006).

La actividad del individuo en el arte es también una tela entramada de hilos tendidos para conectar una idea con las diversas significaciones que se le pueden dar y por lo tanto es un túnel de entrada a la concepción que cada espectador se hace sobre la obra. La metáfora del tejido sigue y se extiende desde lo más concreto hasta el mundo de las ideas, es por naturaleza adaptable y abarcante en todos los aspectos de la existencia. 


\section{CONCLUSIONES}

Podemos ahora concentrarnos en lo que se ha desarrollado a lo largo del texto y que va encaminado a probar nuestra hipótesis inicial: "el tejido aparece como actividad depositaria de un sentido simbólico que va más allá del hecho concreto de entrelazar hebras. Tanto en los mitos de diferentes culturas antiguas como en las teorías que plantea la física cuántica actual, los términos para explicar el origen del mundo se relacionan con la actividad del tejer. Forma parte entonces, del bagaje más íntimo, continuo y primordial del hombre."

Habremos de añadir aquí el camino que tanto los mitos como la ciencia, como la tecnología, han abierto para el quehacer del arte. Cada uno con su contribución especial, han permitido que la interrelación sea una fusión exitosa. En el pensamiento, en los instrumentos, en los materiales, se ha conjuntado el conocimiento que la humanidad tiene, $y$ en un tejido sutil, los artistas pueden tejer obras significantes que muestren la evolución que se ha hecho a través de dichos caminos.

No solamente es la metáfora de la red o del tejido o la trama, ni los mitos sobre el tejer el mundo, sino que realmente existen redes en todos los ámbitos de la vida. Desde la conformación de la materia por redes energéticas, pasando por la imaginación del ser humano 
para explicar el mundo, hasta la red del www, todo en el mundo es una relación de fuerzas establecidas.

Al acercarnos al sistema de pensamiento de las culturas ancestrales de las que hemos partido y que nos muestran rasgos que asimilamos a nuestra vida actual, percibimos la importancia que se le ha dado a la creación en todos sus aspectos. Al recorrer brevemente el mundo prehispánico con algunos de sus mitos e iconografía pudimos darnos cuenta de lo importante que era para ellos concebir la relación entre todo lo existente. Los dioses al crear el mundo acomodaban las fuerzas que estaban a su disposición de maneras nuevas para formar la tierra y la raza pensante que habitaría sobre ella. El tejido funcionaba como la actividad perfecta para construir la metáfora de tejer el mundo. Las diosas que se encargaban del tejido nos mostraron su importancia y su poder. Los diversos símbolos de la fertilidad tanto de la mujer como de la tierra y los elementos que en ella participaban, se encuentran a menudo en lugares especiales de los textos, pinturas o esculturas que se han conservado.

Ocuparse de los mitos no es ocuparse de algo que no tiene sentido; por el contrario, conocerlos y entenderlos nos permite ver toda una serie de situaciones existenciales que perviven en la humanidad hasta los 
tiempos actuales. Ese entendimiento nos lleva a comprender lo que tenemos en común con aquellos habitantes arcaicos: la urgencia por tener algo de qué asirnos durante la vida, la necesidad de dar con explicaciones que permitan vivir con un poco de menos miedo ante la inutilidad de los esfuerzos y la esperanza de que todo tenga algún sentido.

"...las obras de arte, así como los "datos religiosos", tienen una forma de ser que les es propia; existen en su propio plano de referencia, en su propio universo particular. El hecho de que este universo físico no sea el de la experiencia inmediata no significa que no sea real.

...una obra de arte revela su significado cuando es mirada únicamente como una creación autónoma, eso es, en la medida en que aceptamos su forma de ser -la de una creación artística- y no la reducimos a uno de los elementos que la constituyen (...) o uno de sus usos consecuentes y eventuales (...) De la misma manera nos parece que los datos religiosos revelan un significado más profundo cuando se los considera en su plano de referencia y no cuando se los reduce a uno de sus aspectos o contextos secundarios." ${ }^{143}$

La visión de manera total, puede llevarnos a descubrir relaciones que no habíamos sabido, que no habíamos

143 Eliade, Mircea. La búsqueda, p. 18. 
tenido en cuenta. En las culturas de Mesoamérica, existía este tipo de comprensión. Para nosotros, en la época actual nos resulta difícil de hacer a un lado la forma en que vemos, pues llevamos siglos intentando comprender las cosas partiéndolas en pedazos más chicos, para hacer accesible el análisis, pero sin comprender que hemos perdido la capacidad de relacionar.

$Y$ esto afecta el acercamiento que hacemos a cualquier cosa, incluyendo el que se hace hacia las culturas arcaicas y que resulta con doble obstáculo, ya que las consideramos fuera de todo el desarrollo de nuestra llamada "civilización".

"La comprensión de la función de las polaridades en la vida religiosa y en el pensamiento de las sociedades arcaicas y tradicionales requiere un esfuerzo hermenéutico, no una desmitologización. (Los mitos) constituyen, cada uno según su modalidad específica, otras tantas creaciones de la mente humana. No tenemos derecho de tratarlas de manera diferente de la que tratamos, por ejemplo, las tragedias griegas o las religiones mayores. No tenemos derecho de reducirlas a algo distinto de lo que son, es decir, creaciones espirituales." 144

${ }^{144}$ Eliade. La búsqueda, p. 92. 
Los mitos de la creación que describimos en el capítulo correspondiente, nos muestran elementos que pertenecen a la metáfora del tejer, tales como cuerdas por las que se accede a los mundos superiores, símbolos que equiparan la lluvia con la urdimbre y la trama con la siembra; distintos niveles o capas en las que se mueve el ser humano

Mientras, en la ciencia se nos presenta el universo existente como un conjunto de cuerdas que a su vez están unidas a membranas y en las que existe todo el universo. Nos movemos en distintos niveles que tienen distintas vibraciones, los hilos vibran por la energía de la que somos parte. Las membranas son universos completos, de las que salen cuerdas que construyen la estructura de todo lo que existe. La física contemporánea está llegando a un lugar en el que tiene que aceptar que la lógica acostumbrada no funciona como tal. Cuestiones que antes se dejaban a un lado por considerar que formaban parte de la subjetividad, están saliendo a la vista conforme se avanza en los modelos matemáticos que explicarían el universo. Los físicos tienen que lidiar con eso, algunos no están dispuestos a aceptar este nuevo giro que exigen las investigaciones y el avance del conocimiento, pero también hay físicos que abren su mente ante la posibilidad de encontrar algo que ligue todo lo que somos. 
La ciencia se va separando cada vez más del sentido común, de modo que éste ya es opuesto a lo que se ve, ya no se ve un objeto, sino paquetes de energía, conjuntos de moléculas, etc. Los científicos tampoco lo ven con el sentido común sino que lo desarrollan matemáticamente y en teorías abstractas, y para poder presentar esas explicaciones forman modelos, y el modelo que han encontrado que se adapta a la explicación matemática, es precisamente el de las cuerdas y las membranas.

El textil está arraigado en la base de la cultura y aunque el desarrollo matemático de la física es abstracto y casi paradójico, ha utilizado el modelo del textil para tratar de visualizar su explicación en términos más entendibles.

Como ejemplos del cruce de lo horizontal con lo vertical como cuando se hace una urdimbre y una trama, este modelo del tejer dará pie a muchos asuntos que pueden transitar desde lo geométrico hasta los modelos teóricos, tales como el plano cartesiano y el plano relativista (esfera que se mueve en cuadrícula).

El arte es el lugar donde se conjugan el mito y la ciencia, la sociedad y el individuo, lo espiritual y lo concreto, donde se expresa sin cortapisas la percepción de nuestro entorno, y en el arte 
"También se puede detectar el deseo de renovar los antiguos valores y estructuras, la esperanza de una renovatio radical - tal como se puede percibir en los últimos experimentos en el campo del arte, un deseo de romper con todas las formas de expresión que ya han sido gastadas por la historia, pero también la esperanza de recomenzar la experiencia artística ab initio..." ${ }^{145}$

En el arte es donde podemos ver la suma de significados obtenidos de todos los campos del sentido humano.

$Y$ tanto en los mitos, como en la ciencia, como en el arte, las metáforas no pierden validez para lograr claridad, y sobre todo la que describe algún proceso involucrado en el tejido, surge siempre como una metáfora cercana y certera para entrelazar los significados del mundo. En la mente del ser humano se entretejen las diferentes fuerzas que lo mueven formando un complejo tapiz del que puede tomar cualquier hebra para todo tipo de expresiones en las que esté interesado.

La labor textil continúa siendo un modelo para imaginarnos lo esencial y lo originario, lo cercano y cotidiano, lo complicado y lo intrincado. Muchos sitios de nuestro lenguaje cobijan estas metáforas: en la biología se puede hablar de los tejidos, de las fibras musculares,

${ }^{145}$ M. Eliade. La búsqueda, p. 45. 
las representaciones en la ciencia simulan telas 0 membranas, tejidos como el ADN, el tejido social, la trama de la vida, etc. $Y$ todo eso se hace más entendible cuando se liga a la metáfora del tejido.

Lo que tanto el mito como la ciencia y el arte buscan, es poner ante los ojos de todos lo que han hallado $y$ comprendido en su área particular de interés. El mito introduce los rituales con elementos conocidos por los creyentes; la ciencia se toma el tiempo de elaborar ejemplos que accedan al imaginario más familiar de los no entendidos en fórmulas matemáticas, y el arte aglomera los significados en materiales que normalmente nos son cercanos pero que están dispuestos de otra forma. Son enlaces que se buscan para extender la comprensión.

La diferencia pudiera estar en que tanto el mito como la ciencia piensan que deben difundir el conocimiento de su área porque lo consideran el depositario de las verdades últimas, mientras que el arte no insiste demasiado en este punto, lo importante es la expresión en sí.

Es necesario, y ya se ve en los trabajos de eminentes investigadores, retomar la postura de un entendimiento del mundo, no ya desde lo fragmentado y desde áreas específicas, -que si bien sirvieron en su momento para acercarnos a determinados campos del saber aunque nos han conducido a una ceguera parcial-, sino desde el desarrollo de la capacidad de ver la totalidad de 
relaciones que existen entre las diversas áreas que conforman nuestra vida, sin hacer las tajantes separaciones a las que estamos acostumbrados por la ciencia. Es tiempo de completar el panorama. Es necesario tomar en cuenta la conciencia, las emociones, la espiritualidad (en el sentido que maneja Capra, de sentirse uno con todo el universo), la sensibilidad, todas esas cosas que la ciencia tradicional deja afuera o las confina a una estricta relación con las máquinas. Cada vez más se siente la necesidad de una visión holística, porque de hecho es como funciona el mundo; si nos ponemos a pensar detenidamente, no es posible que existan las cosas por separado, siempre tienen lazos con otros fenómenos; y es válido separarlos para su estudio, pero es necesario regresar a la percepción de que todo está unido por distintos caminos.

No podemos sacar partido a todo lo que tenemos cuando hacemos esas distinciones y separaciones que nos conducen a vistas parciales, que nos conducen a la confusión que menciona Bohm, aquella confusión que interfiere en la verdadera percepción de nuestra realidad.

El mundo actual, tan enlazado por los medios de comunicación y por la enorme cantidad de personas que somos, nos exige cada vez más un pensamiento que integre todas las ramas del saber pero vueltas a poner en el árbol del conocimiento, pues las hemos cortado para 
poder estudiarlas y analizarlas, pero es tiempo de hacer la síntesis.

Hemos recibido los hilos enredados, vamos siguiendo su curso entrando y saliendo puntas para luego acomodar la madeja.

Las ideas generales sobre el entendimiento humano... ilustradas por los descubrimientos ocurridos en la física atómica, no constituyen cosas del todo desconocidas, de las que jamás se oyera hablar, ni tampoco nuevas. Incluso en nuestra propia cultura tienen su historia y en el pensamiento budista e hindú ocupan un lugar muy importante y central. Lo que hallaremos es un ejemplo, un desarrollo y fino refinamiento de la sabiduría antigua. ${ }^{146}$

En el mundo de hoy es muy interesante ver cómo se han unido la ciencia y el arte en ese universo de cuerdas y membranas, dando forma a una parte del arte textil contemporáneo, no sólo con la utilización de las fibras en sus diferentes presentaciones y manejos, sino con los mundos digitales entretejiéndose, formando metáforas que tal vez pudieran remitirnos a ese mundo mítico de la

\footnotetext{
146 Julius Robert Oppenheimer en:

http://4grandesverdades.files.wordpress.com/2009/g12/capra-fritjof-eltao-de-la-fisica.pdf
} 
creación por cuanto se repite el acto de dar vida a nuevas manifestaciones. 


\section{BIBLIOGRAFÍA}

-ABREU Gómez, Emilio. (Versión y prólogo). Popol Vuh. Antiguas leyendas del Quiché. Colofón, S. A. México, 2006.

-ANÓNIMO. Chilam Balam de Chumayel. Miguel Rivera Dorado (Editor). Crónicas de América. DASTIN, Madrid, 2003.

-ANÓNIMO. Popol Vuh. Edición de Carmelo Sánchez de Santa María. DASTIN, Madrid, 2003.

-BENÍTEZ, Fernando. Los indios de México. Biblioteca ERA, Serie Mayor. México, 2010.

-BLOM, Franz. La vida de los mayas. Biblioteca Enciclopédica Popular Núm. 25. SEP. México, 1944 -BOHM, David. Sobre la creatividad. (Tr. Alicia Sánchez) Edición a cargo de Lee Nichol. Edit. Kairós. Barcelona, 2009.

-BORDIEU, Pierre. La dominación masculina. (Tr. Joaquín Jordá). Edit. Angrama. Col. Argumentos. Barcelona, 2007. -CHARDIN, Gabriel. La antimateria. (Tr. Glenn Gallardo). Siglo XXI. México, 2001.

-CORCUERA, Ruth. Herencia textil andiana. (Edic. Bilingüe). Fundación CEPPA. Buenos Aires, Argentina, 2010. 
-CORCUERA, Ruth. Mujeres de seda y tierra. Edit. Argentina. Buenos Aires, Argentina, 2006.

-DAHLGREN Jordan, Barbro (Comp.). Historia de la religión en Mesoamérica y áreas afines. I/ Coloquio. Inst. de Inv. Antropológicas, UNAM. México, 1990.

-DAHLGREN Jordan, Barbro (Comp.). III Coloquio de historia de la religión en Mesoamérica y áreas afines. Inst. de Inv. Antropológicas, UNAM. México, 1993.

-DE LANDA, Diego Fray. Relación de las cosas de Yucatán. Consejo Editorial de Yucatán. México, 1986.

-DE MORA, Juan Miguel, Tr. e Intr. El Rig Veda Samhita. EDAMEX, México, 1990.

-DE MORA, Juan Miguel, Tr. e Intr. Los Upanisad. Tomo II. EDAMEX. México, 1990.

-DOWNING, Christine. La diosa. Imágenes mitológicas de lo femenino. (Tr. Maria-Pau Pigem). Edit. Kairós. Barcelona, 1999.

-ELIADE, Mircea. El chamanismo y las técnicas arcaicas del éxtasis. (Tr. Ernestita Champourcin). Fondo de Cultura Económica, México, 1993.

-ELIADE, Mircea. El mito del eterno retorno. (Tr. Ricardo Anaya). Libros de bolsillo. Alianza/Emecé, 1993.

-ELIADE, Mircea. El Yoga. Inmortalidad y libertad. (Tr. Diana Luz Sánchez). FCE, México, 1991. 
-ELIADE, Mircea. La búsqueda. (Tr. Dafne Sabanes de Plou y María Teresa Lavalle). Ediciones Megápolis. Edit. La Aurora. Argentina, 1971.

-ELIADE, Mircea. Mefistófeles y el andrógino. (tr. Fabián García Prieto). Edit. Labor. Col. Punto Omega. Barcelona, 1994.

-ELIADE, Mircea. Nacimiento y renacimiento. EI significado de la iniciación en la cultura humana. (Tr. Miguel Portillo). Edit. Kairós, Barcelona, 2001.

-ELIADE, Mircea. Mito y Realidad. Edit. Labor. Tr. Luis Gil. Barcelona, 1991.

-FRIEDEL, David, et al. El cosmos maya. Tres mil años por la senda de los chamanes. (Tr. Jorge Ferrero Santana). FCE. México, 2001.

-GARZA Tarazona, Silvia. La mujer Mesoamericana. Edit. Planeta Mexicana, México, 1991.

-GLASGOW, Sheldon L. El encanto de la física. (Tr. Antonio Prometeo Moya). Metatemas 37. Libros para pensar la ciencia. Tusquets Editores. Barcelona, 1995.

-GLEISER, Marcelo. The dancing universe. From creation myths to the big bang. Darmouth College Press. NH, USA. 1997.

-GOLDMAN, Moisés Carlos. La doctrina secreta. Introducción a la Cábala. Costa-Amic Editores. México, 1982. 
-GREENE, Brian. El tejido del cosmos. (Tr. Javier García Sánz). Drakontos, Edit. Crítica. Barcelona, 2006.

-GREENE, Brian. El universo elegante. Supercuerdas, dimensiones ocultas y la búsqueda de una teoría final. (Tr. Mercedes García Escamilla). Drakontos Bolsillo. Edit. CRÍTICA, Barcelona, 2006.

-GÜEMEZ Pineda, Manuel. La concepción del cuerpo humano, la maternidad y el dolor entre mujeres mayas yucatecas. Revista Mesoamérica, Año 21, Número 39, junio de 2000. pp. 305-333. CIRMA, La Antigua, Guatemala.

-HARRIS, Marvin. Vacas cerdos, guerras y brujas. Los enigmas de la cultura. (Tr. Juan Oliver Sánchez Fernández) Libros de bolsillo. Alianza Editorial. Madrid, 2008.

-HAWKING, Stephen. El universo en una cáscara de nuez. (Tr. David Jou) Col. Crítica. Edit. Planeta. Barcelona, 2001.

-HEISENBERG, et al. Cuestiones Cuánticas. Escritos místicos de los físicos más famosos del mundo. Edición a cargo de Ken Wilber. Asistente: An Niehaus. Edit. Kairós, Barcelona, 2009.

-HISTORIA ANTIGUA DE MÉXICO. Aspectos fundamentales de la tradición cultural mesoamericana. Vol. IV. Coordinadores: Linda Manzanilla y Leonardo 
López Luján). INAH, UNAM, Miguel Ángel Porrúa. México, 2001.

-IBARRA Ortiz, Hugo. Trama y urdimbre de una tradición. Los sarapes de Guadalupe, Zac. El Colegio de Michoacán. Zamora, Mich. México, 2010.

-KIRCHHOFF, Paul. Mesoamérica. Sus límites geográficos, composición étnica y caracteres culturales. (en línea) Xalapa, Ver., Al Fin Liebre Ediciones Digitales. 2009. 12 pp. (Ref. 30 de septiembre de 2012). Disponible en Web: <http://.alfinliebre.blogspot.com/> -KLEIN, Cecelia F. "Woven Heaven, Tangled Earth: A Weaver's Paradigm of the Mesoamerican Cosmos." En Ethnoastronomy and Archaeoastronomy in the American Tropics, ed. Anthony F. Aveni and Gary Urton. Annals of the New York Academy of Sciences 385 (1982).

-KOLADOWSKI, Leszek. La modernidad siempre a prueba. (Tr. Juan Almela). Edit. Vuelta. México, 1990. -KRICKEBERG, Walter. Las antiguas culturas mexicanas. (Tr. Sita Gars y Jasmín Reuter). FCE, México, 1992.

-LARREA Príncipe, Iratxe. El significado de la creación de tejidos en la obra de mujeres artistas. (Tesis en formato Digital) Servicio Editorial de la Universidad del País Vasco. 2007.

-LEANDER, Birgitta. Herencia cultural del mundo náhuatl. Sep-setentas-Diana. México, 1980. 
-LEÓN-PORTILLA, Miguel. Los antiguos mexicanos. Colección popular FCE. México, 1985.

-LEÓN-PORTILLA, Miguel. Rostro y corazón del Anáhuac. Asociación Nacional del libro, A.C. México, 2001.

-LEÓN-PORTILLA, Miguel. Toltecáyotl. Aspectos de la cultura Náhuatl. FCE, México, 2003.

-LEVINAS, Marcelo Leonardo. Las imágenes del universo. Una historia de las ideas del cosmos. Col. Ciencia que ladra, Seria Mayor. Siglo XXI editores. Buenos Aires, 2006.

-LEVY-BRUHL, Lucien. La Mitología Primitiva. Col. Historia, Ciencia y Sociedad. Edic. Península. Barcelona, España. 1978.

-LEVI-STRAUSS, Claude. Tristes Trópicos.

http://ir.nmu.org.ua/bitstream/handle/123456789/17897/717eal 6d0ae804b91698434d929306ec.pdf? sequence $=1$

-LOK, Rossana. "The House as a Microcosm: Some Cosmic Representations in a Mexican Indian Village," en The Leiden Tradition in Structural Anthropology: Essays in Honor of P. E. de Josselin de Jong, ed. R. de Ridder and J. A. J. Karr Mans (Leiden, E. J. Brill, 1987).

-LÓPEZ Austin, Miguel y MILLONES, Luis. Dioses del norte, dioses del Sur. Religiones y cosmovisión en Mesoamérica y los Andes. Edit. ERA. México, 2008.

-MARKS G., Patricia. Tejedoras: Generaciones Reunidas. "Evolución de la creatividad entre los mayas de Chiapas". 
(Tr. Francisco Álvarez Quiñones) CIESAS. Ed. Uc. México, 2004.

-MATUL, Daniel y CABRERA, Edgar. La cosmovisión maya. Tomo Uno. Liga maya, Guatemala, 2007.

-MORRIS Jr., Walter S. Diseño e iconografía. Chiapas. Col. Geometrías de la imaginación. CONECULTA, Chiapas. México, 2009.

-NICOL, Eduardo. Crítica de la razón simbólica. FCE. México. 1982.

-NOVAK, Richey. Me and the big bang. Confessions of a Modern-day mystic. iUniverse, Inc. IN. EUA. 2010.

-PLATÓN. Diálogos. Edit. Porrúa. México, 1978.

-POHL, Mary y FELDMAN H., Lawrence. "The Traditional Role of Women and Animal in Lowland Maya Economy", en K. V. Flannery (ed.) Maya Subsistence. Academic Press, Nueva York, 1982, pp. 295-311.

-REES, Martin, et. al. Los próximos cincuenta años. El conocimiento humano en la primera mitad del siglo XXI. Edición a cargo de John Brockman. (Tr. Eugenia Vázquez Nacarino y Miguel Martínez-Lage). Edit. Kairós. Barcelona, 2004.

-Revista de Arqueología Mexicana. Edición especial. La religión mexica. Catálogo de dioses. Núm. 30. Abril, 2009. -Revista de Arqueología Mexicana. La mujer en el mundo prehispánico. Vol. V. Núm. 29 enero-febrero, 1998. 
-Revista de Arqueología Mexicana. La religión mexica. Vol. XVI. Núm. 91. Mayo-junio, 2008.

-Revista de Arqueología Mexicana. Los dioses mayas. Col. XV. Núm. 88. Noviembre-diciembre, 2007.

-Revista de Arqueología Mexicana. Mitos de la creación. Vol. X. Núm. 56. Julio-agosto, 2002.

-RODHE, Teresa. "El tejido del Cosmos, residuos de un mito perdido" en Dahlgren Jordan, Barbro (Comp.). Historia de la religión en Mesoamérica y áreas afines. II Coloquio. Inst. de Inv. Antropológicas, UNAM. México, 1990.

-SÉJOURNÉ, Laurette. Cosmogonía de Mesoamérica. (Tr. y Edic. Martín Soler). Siglo XXI Editores, CONACULTA, INAH. México, 2004.

-SCHAEFER, Stacy. "The Loom as a Sacred Power Object in Huichol Culture," in Art in Small Scale Societies: Contemporary Readings, ed. Richard Anderson and Karen Field (Englewood Cliffs, NJ: Prentice Hall, 1993).

-SHARER, Robert J. (Tr. María Antonia Neira Bigorra). La civilización maya. FCE, México, 2003

-SILVERMAN, Gail. El tejido andino: un libro de sabiduría. (Tr. Javier Flores Espinosa y Mariana Pease Mould.) México, 1994. 
-THOMPSON S., J. Eric. Historia y religión de los mayas. (Tr. Félix Blanco) Siglo XXI, col. América nuestra. México, 2008.

-THOMPSON, Reynaldo, (coord.). Las imposturas de Odisea. Reflexiones sobre el arte digital. Azafrán y Cinabrio. Universidad de Guanajuato. Guanajuato, México, 2010.

-URANGA, Ángel M. Introducción a Física de Partículas y Teoría de Cuerdas. "Teoría de Cuerdas y Gravedad". Instituto de Física Teórica UAM/CSIC, Madrir.

-VALDIVIA, Benjamín. Sentidos Digitales y entornos metaartísticos. Libros a cielo abierto. U de Gto. Guanajuato, México. 2009.

-VÁZQUEZ y De los Santos, Elena. Los Tenangos: mitos $y$ ritos bordados. Arte textil Hidalguense. CONACULTA, Arte Popular de México, México, 2008.

-VENTURA, Carol. Mesoamérica: weaving and fertility. Copia personal.

-YAÑEZ, Agustín. (Estudio preliminar, selección y notas). Mitos indígenas. Biblioteca del estudiante universitario Núm. 31. UNAM, México, 1991

\section{Páginas web:}

-Sobre estudios femeninos. Complutense, Estudios femeninos. 
http://www.instifem.org/Portals/0/PropertyAgent/399/Files/28/Cuadernos-

Mujeres, \%20arte\%20y\%20literatura.pdf

-Artículos sobre arte y diseño.

http://www.nytimes.com/2007/01/27/arts/design/27lace.html?_r=0

-Thread for Thought. Ensayos.

http://www.threadforthought.net/2012/09/18/subversive-knitting/

-Video. http://artyarn.blogspot.mx/2009/07/knitting-machine.html

-Artículo

sobre

Lotman.

http://www.ugr.es/ mcaceres/entretextos/pdf/entre2/lotman.pdf. Tr. Gastón Gainza y Álvaro Quesada.

-Marlboro College. Artículo Carol Hendrikson.

http://www.marlboro.edu/academics/faculty/hendrickson_carol/documents/va r-visual_field_notes_article_11-08-

-Brigham Young University. The dance of first beginnins: Contemporary Maya Creation Rituals in a World Context.

https://byustudies.byu.edu/PDFLibrary/39.2ChristensonDance-54e6dd14-

4e2b-43bb-bd70-61166c6e45f7.pdf

-Alguna bibliografía sobre temas Mesoamericanos.

http://www.mesoweb.com/features/fabric/bibliography.html

-The College Journal of Anthropology. The Development and Symbolism of Textiles.

http://anthrojournal.com/issue/october-2011/article/the-development-and-

symbolism-of-maya-textiles

-Julio López Saco. Madre salvadora. Hermenéutica de un mito antropogónico chino. Escuela de Historia, Caracas, Venezuela. Consultado en línea en el sitio.

http://ceaa.colmex.mx/aladaa/XII\%20CONGRESO\%20INTERNACIO

NAL\%20DE\%20ALADAA/lopezjulio.pdf

-SORLI, Nuria. "Breve historia de la sexualidad". Revista de Sexología Identidades Noviembre. Publicado en 
http://www.identidades.org/revista/historia_sexualidad.html. Fecha de revisión 14/07/2012

-Mauro Arnoldo Montejo Díaz. La sexualidad maya y sus diferentes manifestaciones. Tesis para obtener el grado de licenciado en Atropología. Univ. San Carlos de Guatemala. 2012.

http://biblioteca.usac.edu.gt/tesis/14/14 0469.pdf

-Lista de mitos en las distintas civilizaciones:

http://listas.20minutos.es/lista/los-mitos-de-la-creacion-del-mundo3420771

-Artículo "El concepto de habitus "Con Bourdieu y contra Bourdieu" dialnet.unirioja.es/descarga/articulo/3874067.pdf

-Artículo: Joaquín González Álvarez. Cuerdas, Branas y Dimensiones. http://casanchi.com/ref/cuerdas01.pdf. New York Academic Science. Vol. 385:1-35. New York 1982.

-Artículo sobre la evolución tecnológica del telar. Raúl Vicente Galindo $\begin{array}{lllll}\text { Sosa } & y & \text { Yissel } & \text { Hda } & \text { Romero }\end{array}$ http://www.revista.unam.mx/vol.9/num11/art93/art93.pdf

-Artículo: Evolución de los telares y ligamentos a través de la historia. Pilar Borrego Díaz.

http://ge-

iic.com/files/Publicaciones/Evolucion de telares y ligamentos.pdf -Artículo en un blog sobre la explicación de la polémica sobre los dogón.

https://misteriosaldescubierto.wordpress.com/informes-especiales/losdogon/

-Libro Aprender a fluir de Csikszentmihalyi

http://formarseadistancia.eu/biblioteca/aprender a fluir.pdf

-Ciberfeminismo

http://e-

mujeres.net/sites/default/files/Ciberfeminismo Creatividad\%20y\%20c omunicacion.pdf 
-Artículo

sobre

el

pueblo

Dogón.

http://www.artehistoria.com/v2/contextos/8593.htm 